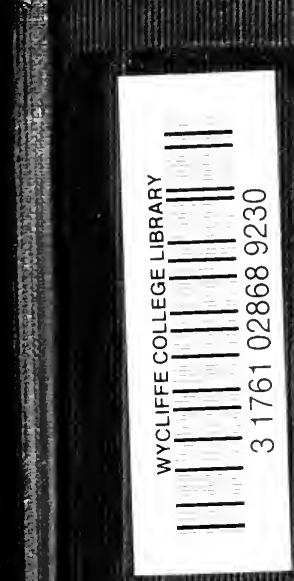




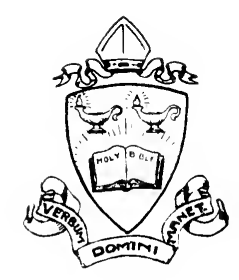

LIBRARY

玨yrlifte

TORONTO

Shelf No. BS $1 / 71, W 93$

genus

Nan 171922 



$$
\text { . }
$$


SCIENTIFIC CONFIRMATIONS

OF OLD TESTAMENT HISTORY 


\section{BY THE SAME AUTHOR}

The Logic of Christian Evidences-Andover: Warren F. Draper, I880, I2mo, pp. xii, 312. \$1.50.

Stldies in Science ind Religion-llarren F. Draper, I882, I 2 mo, pp. xvi, 390. \$1.50.

Charles Grandson Finney-(American Religious Leaders Series)-Boston: Houghton, Mifflin \& Co., I 89 I, I $2 \mathrm{mo}$, pp. $329 . \quad \$ 1.25$.

MAX AND THE GLACIAL PERIOD-(International Scientific Series)-New York: D. Appleton \& Co., r897, I 2 mo, pp. $\mathrm{xxxii}, 358 . \$ 1.75$.

Greenlane ICE Fields ind Life in the North ATLANTIC-I). Appleton \& Co., I896, r2mo, pp. xv, 407. \$2.00.

Scientific Aspects of Christian Evidences-D. Appleton \& Co., r 898 , r2mo, pp. xi, 262. \$1.50.

Asiatic Russia-New York: McClure, Phillips \& Co., I902, two vols., 8vo, pp. 6oo. \$7.50.

The Ice Age in North Americ ANd its Bearings UPON THE ANTIQUiTy OF MAN-Oberlin: Bibliotheca Sacra Co., 5th ed., I9I2, 8vo, pp. xxi, 763 . $\$ 5.00$.

('RIGIN AND ANTIQUITY OF MAN-Bibliotheca Sacra Co., I 9 I 2, I 2 mo, pp. $\mathrm{xx}, 5+7 . \$ 2.00$. 


$$
\text { . }
$$




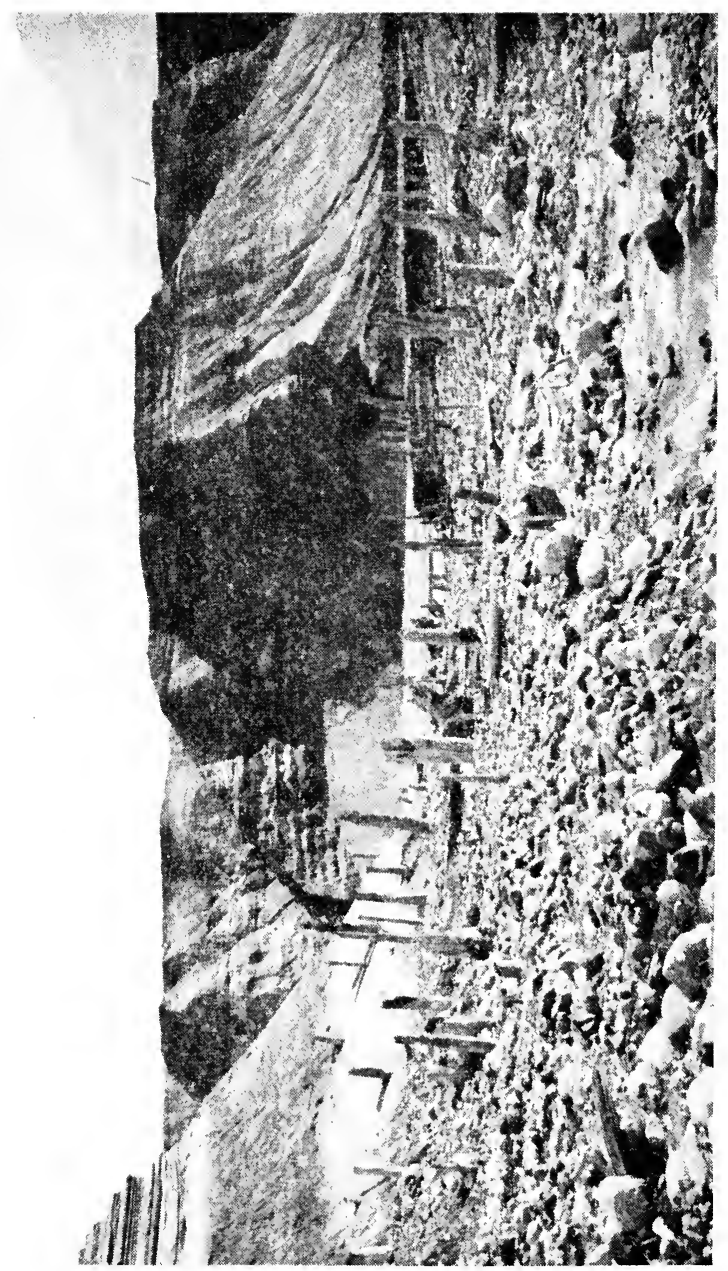




\title{
Scientific Confirmations of Old Testament History
}

\author{
BY
}

\section{G. FREDERICK WRIGHT \\ D. D., LL.D., F.G.S.A.}

" An apparent improbability is, when verified, the surest witness to the truth"

ILLUSTRATED

THIRD EDITION

OBERLIN, OHIO, U. S. A.

BIBLIOTHECA SACRA COMPANY

1913 
COPYRIGHTED I 906 BY BIBLIOTHECA SACRI COMPANY

The News Printing Co., Oberlin, $u$. 
To the

\section{Trutgites uf (Bhrrliu Conllage}

in recognition of the generous interest which

has made the prosecution of my

investigations possible

I dedicate this volume 


\section{PREFACE.}

THE conclusions recorded in the present volume are both a cause and a result. They were the cause of the establishment of the chair which I now occupy, and they are the result of the investigations made possible by the generousness of its provisions. Fourteen years ago these conclusions were dimly seen " as trees walking." At that time, the importance of enabling me to follow out to the full extent the investigations upon the relations of man to the post-Tertiary (or Glacial) epoch which I had been prosecuting for twenty years led the trustees of Oberlin College to establish the professorship of The Harmony of Science and Revelation, and to appoint me the first incumbent. The provisions of the chair allowed me the freedom of the first half of each year, in order to pursue at my own discretion the lines of investigation upon which I had entered; while a year and a half was at one time granted me to make a complete circuit of the northern hemisphere to visit regions in the Old World which are ordinarily inaccessible. For these and other privileges so generously granted me by the trustees and faculty of Oberlin College, I here take occasion to express my profound appreciation. 
Since my appointment, the subject has never for one moment been out of my mind, and I have availed myself of every opportunity to enlarge the horizon of my vision in the direction of the interpretation both of the Bible, and of the rapidly accumulating facts relating to recent geological events which have had a profound influence upon the early history of man. In I904 the results so far attained were made the theme of the Stone Lectures in Princeton. 'Their publication, however, has been delayed until the present time, in order that I might avail myself of the information gathered during a third extended visit to the localities on the eastern continent where the facts could be most profitably studied. It has also seemed best not to retain the lecture form, but to treat the subject in the more elaborate manner which is suitable for the reader. In a subsecunent volume I shall treat of the broader question of 'The Origin and Antiquity of the Human Race,-a subject upon which recent geologrical investigations are shedding new and increasing light.

The present work is committed to the public in the hope of doing something to reëstablish confidence in the historical statements of the ()ld 'Festanent, and, at the same time, of so unfolding the marvelous geological events of the post-Tertiary period as to incite the 
general reader to a closer study of its significant and overwhelming facts, which invite investigation on every hand. The discussion is believed to be also eminently worthy of the attention of geologists, many of whom are so engrossed in their special studies that they have little leisure or inclination to consider the action of geological forces in their more general application. All students both of the Bible and of the early history of mankind, as well as of geology, will, I am sure, find satisfaction in the light which science is here made to shed upon some of the early traditions of mankind.

The convictions formulated in the present volume have deepened as investigations have proceeded from year to year. It remains to attempt to get the facts so clearly and fully before the public that it shall have the same basis for judging the conclusions which the writer has attained for himself. As such an attempt, the volume is commended to the charitable consideration and the criticism of all students who have given attention to any of the phases of the broad subject which has here received general treatment.

(.. Frederick IVright.

Oberlin, ()hio, November 3, igOo. 


\section{NOTE TO THIRD EDITION.}

IT is gratifying to observe that Professors Davis and Huntington confirm the existence of the Pleistocene marine terrace at Trebizond (see p. 315), and describe a similar one at Baku six hundred feet above tide (see "Explorations in Turkestan," 1905, p. 28).

Apropos of the discussion on pages $338-3+2$, Professors R. S. Tarr and (). D. von Engeln estimate that, during the closing stages of the Glacial epoch, the Mississippi had to dispose annually of sixty times the amount of its present flow of water (see Zeitschrift für Gletscherkunde, vol. vi. (1911) p. IO4).

Many discoveries, detailed with more or less minuteness in my "Origin and Antiquity of Man" (1912) confirm the belief that both antediluvian (palieolithic) and existing races migrated from a common center in Central or Western Asia.

The rapidity and extent of the changes that have occurred on the earth since the beginning of the Glacial epoch have received numerous and striking illustrations in recent observations (see my "Ice Age in North America" ( $5_{\text {th }}$ ed.), pp. 7I, 74, 15I; "()rigin and Antiquity of Man," pp. 202, 3I 4 ).

G. Frederick Wright.

()berlin, ()hio, March 7, 1913. 


\section{CONTENTS.}

\section{Ch.lPTER 1.}

The Witness of the New Testament Christianity an historical religion-W Written history indispensable to progress-A stimulus to the intellect -A high degree of certainty attainable by historical evidence-Historical evidences of Christianity-The Old Testament indorsed by the New.

\section{Chapter II.}

Middle and Later Jewish History

Different ways of writing listory-Connecting links of the argument-Historical setting of the book of Daniel-Destruction of Sennacherib's army-The times of Ahab and Jehu-The black obelisk of Shalmaneser II.-The Moabite stone-The expedition of Shishak-Brevity of the book of Judges-Joshua's command to the sun to stand still.

\section{Chapter III.}

Israel in Egypt

Principles of interpretation-Famines in Egypt-The sources of the Nile-Vacillations of the government.

\section{Chipter IV.}

The Exodus

Definition of miracle-Passage of the Red SeaPhysical conditions north of Suez-Former depression of the land-The effect of wind on water levels. 


\section{Chapter V.}

Physical Preparation for Israel in Palestine I I 3

The great "fault" of the Jordan Valley-The falling of the walls of Jericho-The parting of the waters of the Jordan-The destruction of Sodom and Gomorrah-The fourteenth chapter of Genesis.

Chapter Vi.

Traditions of the Deluge

Comparison with other traditions-The log-book of Noah-Extent of the Deluge-The date of the Deluge.

Scientific Credibility of the Deluge

The uniformitarian theory in geology-All geological movements comparatively slight-Recent great geological changes-The latest geological epoch one of great changes of level.

\section{Chapter Vilis.}

The Glacial Epoch as a Vera Causa $2 \cdots$

Magnitude of the forces involved-Recency of th: Glacial epoch.

Evidences of a Deluge in Europe

The rubble drift, or "head"-()ssiferous fissures-

The loess deposits of Europe. 
Evidence of a Deluge in Asia

The loess of Northern China-Wind and water the distributing agencies-Corroborative evidence of a depression of Asia-Remains of antediluvian man.

\section{Chapter XI.}

'i he Deluge in North America 323

Glacial lakes of North America-Floods of the Missouri River-Recent destruction of animal speciessummary and conclusion-(Bbjections answered.

\section{C'hipter Xil.}

Cicnesis and Science

Earlier views of the author-Dana's summary of the scientific facts--Remarkable parallelism of the Nosaic account. 


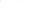




\section{LIST OF ILLUSTRATIONS.}

Page

Interglacial Forest Lncovered by the Retreat of the Muir Glacier, Alaska

Frontispiece

General View of the Crow's Nest from the Pyramids 98

Near View of the Raised Beach on the Crow's Nest 99

Conglomerate Knob in Desert North of Suez

View of Jebel Attaka, from the Vicinity of Pi-hahiroth rog

Submerged Trees above the Cascades of the Columbia River

133

Cut for the Canal South of the Cascades $\quad$ I39

Sedimentary Banks of the Jordan $\quad \mathbf{1}+2$

Burning Oil Well at Baku $\quad{ }^{+7}$

Cross-Section Showing the Depth of the Southern Part $\begin{array}{ll}\text { of Lake Baikal } & 209\end{array}$

Raised Beach in Sweden 2 r9

General View of the Rubble Drift at East Brighton, England

Near View of the Risised Beach at East Brighton

Section of the West End of Sangatte Cliff, near Calais

Diagram Showing the Direction of the Currents on a Hill Range during Uplift

The Mountain of Santenay

Transverse Section of the Rock of Gibraltar 263

Mouth of the Cave of San Ciro, near Palermo 266

Raised Beach on the Island of Guernsey 276

Diagram Section across the Island of Guernsey $\quad 278$

Section from La Motte to Ubé 279

Delta of Loess at Nankau, China 288

Rows of Houses in the Loess at Shiwantse, China 290

House in the Loess at Shiwantse 294

A Bluff of Partially Stratified Loess in China 296

Excavated Cliff of Loess at Tashkent 299

Raised Beach at Trebizond $3 \mathbf{1 6}$ 


\section{ILLUSTRATIONS AND MAPS.}

Bluff of Loess at Kief, Russia

Page

Cross-Section of the Osage Trough at Tuscumbia, with a Canadian Boulder

Bluff of Loess facing the Missuriri River at Lansing, Kan.

Stratified Loess at St. Joseph, .lio.

Nammoth from Siberia in the Museum at St. Petersburg

MAPS,

Map of the Delta, or Lower Egypt

Nap of Lower Egypt during a Depression of Three Hundred Feet

102

Map of Lake Baikal

208

Nap of Glaciated Areas in North America and Europe

222

Map of Bay of Palermo

Nap of Supposed Post-Glacial Submergence in Asia 304

Map of Glaciation in Eastern and Central United States

Map of the Glaciated Area in the Lower Missouri Valley 


\title{
Scientific Confirmations of Old Testament History.
}

\author{
CHAPTER I.
}

THE WITNESS OF THE NEW TESTAMENT.

Christianity is preëminently an historical religion. Its specific characteristics consist in the revelation of God made through the personal life of the incarnate Word. Because the Word became flesh and dwelt among us, we have been enabled to behold his glory, even the glory of the only-berotten Son of God. Our knowledge of the saving truths revealed in the life of Christ does not come to us through intuition or immediate revelation, except as these illumine lines of historical evidence. Christ was crucified once for all, and the knowledge of the fact was committed to the keeping of the historical forces radiating throughout the future from that point of time. This precious treasure of knowledge was committed to the care of the first disciples of Christ, and through them to the Christian church, thereby exalting her members to the responsible position of co-workers with God in the spread of his kingdom on earth. All this is briefly expressed in the familiar statement that the church of Christ is a 
missionary organization. The last command of her divine Lord and Master was, "Go ye, therefore, and make disciples of all the nations, baptizing them into the name of the Father and of the Son and of the Holy Spirit: teaching them to observe all things whatsoever I commanded you."

This dependence of Christianity upon facts which can be proved only through historical processes is often urged as an objection to the system, it being alleged that it is unreasonable to suppose that in so important a matter as their religious life, God would make his creatures dependent upon such uncertain evidence as that by which historical facts are established. But closer consideration of the subject will show: ( I) that man's dependence upon historical facts for his highest religious development is in close analogy with his dependence upon the past for civilization in general; (2) that that ordering of Divine Providence by which successive generations are made largely dependent upon their predecessors, and by which the favored portions of mankind to whom much has been given are made responsible for the transmission of these gifts to the less favored, is one of the richest boons which have been conferred upon the race: (3) that the certainty of conclusions reached through historical evidence may be, and in the case of Christianity is, of the very highest 
order, and such as universally commands the assent, and directs the activity, of men in their ordinary affairs. WRITTEN HISTORY INDISPENSABLE TO PROGRESS.

I. With reference to the first point it is sufficient to remark, that, as an intellectual being, man is chiefly characterized by his ability to attain, through inductive reasoning, a knowledge of the past which lies beyond the reach of memory, and to make it the basis of advancing to that wider knowledge of the future which secures the progress of the race. Indeed, it is just this which makes the difference between civilization and savagery. The savage is limited in knowledge to his immediate intuitions and perceptions, eked out by still scantier information obtained through tradition and his imperfect means of obtaining testimony from his contemporaries. It is almost exclusively through books that the successive generations of the civilized world obtain the results of the past experience of mankind, and thus are able to lift themselves to a height from which the horizon of their intellectual vision can be greatly expanded. It is chiefly by reason of written documents that each generation of civilized men is enabled to stand upon the shoulders of the generation which has preceded. Destroy literature, rob the present of that definite knowledge of the past which it ob-tains through written documents, and progress would 
at once be checked, and mankind would revert to barbarism.

If one is inclined to challenge this proposition, his doubts will be dissipated by a little well-directed reflection. In astronomy the whole system rests upon disconnected measurements and observations made and reported by a great number of observers whose record is the basis for all mathematical calculations concerning the size and movement of the heavenly bodies. Our estimation of the size of the earth, for example, is dependent upon a few careful measurements which have been made upon an are of its circumference. It is not within the power of the individual to repeat these measurements. He is compelled to trust the record of work done by others. In chemistry, likewise, it is out of the question for each individual investigator to go through all the processes by which the nature of the various elements has been determined. It would be a sorry condition of things, indeed, if all the violent explosives and deadly poisons had to be discovered anew by every experimenter. Geologr, also, is a system of facts discovered by a wide range of investigators. It is entirely beyond the capacity of any one man to survey the whole field. The work of the United States Geological Surrey is carried on by a whole army of investigators who bring in their results to await corre- 
lation at the central bureau by experts dependent for their facts upon the written reports.

It is, however, in the realm of those higher and more delicately balanced forces pertaining to the political and social life of man that he is most strikingly dependent upon the wisdom handed down from preceding generations. Imperfect as are political and sociological theories, how utterly useless would they be if we were shut off from the access to the world's experience which is furnished us through written documents pertaining both to the past and to the present! The statesmen who mark out the lines of national polity for the future, and the military commanders who control the armies that serve as the bulwark of national defense, would be poorly prepared indeed for their work if they had but the imperfect knowledge of the experience of others which is furnished by oral testimony. If it be true, as it certainly is, that the patriot and statesman has no lamp but the past to guide him into the future, he must set a very high value upon the definite historical records in which the light of the past is concentrated. Indeed, what would statesmen and judges do without precedent by which to guide their action amid the complicated casuistries arising anew with every step into the future? It should not therefore seem strange that in religion we are bound to the past by a similar law of 
dependence, nor that the written word should be highly exalted among the agencies by which the wisdom of the past is brought within our reach and made serviceable to us. In fact, it is in accordance with ali analogy that the highest religion of the world should be perpetuated through historical forces, and embodied in a book.

A STIMUlus TO THE INTELLECT.

2. From an intellectual point of view, also, it is not a reproach, but a glory, to Christianity, that it is an historical religion; since it brings into exercise, through historical research, the highest powers of our rational nature, and cultivates that capacity for inductive reasoning which is the pride of the present age of advancement. Indeed, history affords the most important of all fields for inductive reasoning, and in its study brings into requisition all branches of knowledge and every faculty of the intellect. Hence it is the best basis possible for the symmetrical development of the human mind. For it is worthy of notice in this connection that there is not that difference between direct and circumstantial evidence which is often insisted upon. All evidence is circumstantial. The direct testimony of a witness is but a circumstance. The truth or falsity of his testimony has to be determined by a wide range of considerations. The 
existence of a written document is likewisr but a circumstance. The validity of its testimony has to be established by the circumstances under which it has come to our notice, by inspection of its contents, and by comparison of its statements with the known conditions surrounding its alleged facts. Thus every department of science may be brought in to contribute evidence, of more or less cogency, bearing upon the truth of a literary document. The question of its forgery may depend upon chemical analysis of its ink, or upon the water-lines in its paper, or upon the incapacity of a forger to produce the document withir: a given time, or upon the inability of later writers perfectly to simulate the character of the times to which the doctiment purports to pertain.

It will prepare us for a readier acceptance of the divine plan of revelation if we consider more fully the ircidental advantages arising from having this treasure committed to the earthen vessels of history, and made dependent upon our care for its preservation. The highest favor which God has conferred upon man is that of exalting him to the position of a co-worker in the plan of salvation. It is at once a recognition of his godlike qualities, a means of his highest development, and the gratification of his noblest aspirations. At first thought it would seem that Almighty Power could 
best accomplish its objects directly, without the intervention of so imperfect a secondary cause as is the human will. Indeed, from Celsus to Huxley it has been a standing objection to the Christian system that miracles are so few. "If," it is said, "the God of the Christians is able to perform miracles, and is at the same time compassionate, it is absurd that his miraculous acts should be so limited as they are represented to have been in the biblical record." The rational justification of this plan by which so much is left to human initiative is, that thereby man is exalted to a position of high privilege, in which a field of boundless development is open before him. By virtue of his moral freedom, man becomes the architect of his own fortune. and at the same time in a most important sense his brother's keeper. The obedience which he renders to law is not forced and mechanical, but partakes of the divine element of all-comprehensive love.

The dependence of children upon their parents is but a type of the dependence, in a broader sense, of the successive generations of mankind upon their ancestors, and of the less-favored races of the world upon the more-farored. Results of the highest and most beneficent order follow upon the divinely orlered arrangement that man is everywhere and always his brother's keeper. In no other way are we so stimulated to honor 
our ancestors as through the study of the heroic efforts which they have made to perpecuate for the use of their successors the truths of experience and revelation which have been committed to their keeping. Among the strongest of all earthly ties are those which bind a pupil to his teacher. It is impossible to overestimate the value of the bonds of affection which are being formed at the present time between heathen and Christian nations through the great missionary movements which are in operation. Through these efforts the unfathomable depths of compassion on the one side and gratitude on the other are opening up, and the whole life of the world is being enriched beyond measure for time and eternity. Only when Christian nations shall give to others as freely as they have received will the brotherhood of humanity reach its fullest expression and culmination.

A HIGH DEGREE OF CERTAINTY ATTAINABLE BY HISTORICAL EVIDENCE.

3. It is a common mistake of the present age to underestimate the certainty which is arrived at through historical evidence. In the recent remarkable development of mathematical and experimental sciences, many persons seem to have lost sight of the fact that probable evidence is still all we have to go upon when we venture a step beyond our intuitions and immediate per- 
ceptions. Wherever mathematical formulx are applied to realities, the conclusions partake of the uncertainty which besets our knowledge of the real things which we multiply or divide,-in other words, proof ceases to be demonstrative; - while in direct perceptions all that we are absolutely certain of is that which comes within the sphere of immediate sensation, only a portion of which is carried along in our experience by memory. The conclusions reached by inductive reasoning are, therefore, from a mathematical point of view, defective. Yet they are all we have with which to guide our conduct and direct our movements through illimitable space and unending time. As moral and practical beings, it is our business to form the best conclusions we can from the data which are given us, and act upon them according to the light we have. It is this which constitutes the moral trial of mankind.

In the literature of the present day we often meet with such statements as that "we cannot prove the immortality of the soul," "we cannot proze the benev. olence of the Creator," "we cannot proz'e the genuineness of the Fourth Gospel or of the Second Epistle of Peter"; and this by writers who would feel insulted if they were charged with disbelieving in immortality or in the benevolence of God, or of believing in the spuriousness of any of the books of the New Testament. 
Nor would they be willing to be set down as pure agnostics respecting these questions. Many who are given to such ill-considered statements both misrepresent themselves and confuse their readers by using the word "proof" in a sense which is proper only in the mathematical and purely demonstrative sciences. When they are questioned more carefully, it is usually found that they acknowledge such a preponderance of evidence upon many of these questions which they have said to be incapable of proof, that they firmly cherish their conclusions as practical beliefs, and use them as the zuide of their lives. Thus do they illustrate the allimportant truth that in the practical affairs of life we are not at liberty to demand any clearer and higher evidence than the nature of the subject will admit, and that, so long as there is a preponderance of evidence upon one side, we are to follow that, and permit it to shed what light it can upon the pathway of the future.

But the evidences of Christianity are far from being of a low order. The truthfulness of the historical statements made in the New Testament is capable of being established to a very high degree of certainty; so that the Christian system, so far as it rests upon those statements, takes high rank among the inductive sciences as they are regarded even in the twentieth century. Any one who should doubt the general historical statements 
14 The W'itness of the New Testament.

current concerning the career of Alexander the Great, or of Julius Casar, or of Charlemagne, or of Napolcon Bonaparte, either is grossly ignorant or has a very abnormally constituted mind. Without stopping to analyze the evidence through which we arrive at this impregnable belief concerning such historical careers, we can affirm with perfect assurance that these and innumerable similar beliefs are as firmly established, and approach as near to certainty, as any of the conclusions arrived at by inductive reasoning. History is an inductive science whose central facts are as certain as those of any other inductive science, and whose range of uncertainty is no greater when one gets away from their central conclusions. Indeed, we know less about the borderlands of chemistry, astronomy, and geology than we do about the borderland of human history. ${ }^{1}$

\section{HISTORICAL EVIDENCES OF CHRISTIANITY.}

In order to get started upon our investigation of the foundations of Old Testament history, it will be profitable, and indeed necessary, to give a résumé of the evidence upon which we receive the New Testament as a correct historical representation of the origin of Christianity; for Christianity is most clearly an outgrowth of Jewish history, and, to a degree which is now too often disregarded or denied, the New Testa- 
ment is sponsor to the Old, and sets us upon an investigation of Old Testament history with presumptions regarding its truthfulness which are of the highest evidential value.

He who inherits Christianity as his birthright is so early made familiar with Christian civilization that it is difficult to realize that it is not a natural product of the world in which he lives. On every hand he sees churches dedicated to the worship of Jesus Christ, and, upon entering them, joins in services which from beginning to end center upon the personal history of the Founder to whom the building is dedicated. At the beginning of the services Christ's biessing is invoked. The anthems of the choir and the hymns of the congregation sound alond the praises of Christ. Some portion of the Bible is read with solemn reverence. The sermon is an exposition of some text of this sacred scripture. The audience is dismissed with the benediction of the Father, and the Son, and the Holy Ghost.

Gathered about these churches are numerous other less formal agencies for impressing the reality of this history upon the minds of the young. The ordinances of baptism and the Lord's Supper give unique prominence to the central historical facts of Christ's life: while the daily use of the calendar, which reckons time from the birth of the Founder of Christianity, compels 
even the most reluctant to do homage to the Divine Master. In short, he who is born in a Christian land is, at the outset, launched upon a mighty stream of Christian influences which every one with the clearness of direct intuition sees must have an adequate fountainhead.

The normal human mind is so constituted that it cannot easily disengage itself from the presumption that so powerful and beneficent a stream of influence as Christianity is, must have originated through some such historical facts as are recorded in the sacred books which are now read in the churches. So strong is this presumption, that one is not at liberty to disregard it, except upon obtaining abundant evidence to the contrary. The very existence of Christianity as embodied in the ordinances and Christian activities of the church is its strongest evidence, and, in absence of proof to the contrary, is entitled to absolute sway. The burden of proof does not properly fall upon the defenders of Christianity, but upon those who attack it and endeavor to overthrow it. Its position is like that of a man or woman of good repute, whose character is not to be challenged except upon the presentation of adequate positive evidence. Eren a criminal is not compelled to proze his innocence, but is allowed simply to defend himself against the definite charges of his 
accusers. The evidential value of such presumptions should not be overlooked. In a well-established system the general presumptions in its favor rightfully prevail until all objections are definitely supported by positive evidence. The acceptance of the theory of gravitation, for example, is not rendered untenable by the fact that there are many movements of the heavenly bodies that cannot yet be brought clearly in harmony with it through definite knowledge of the causes producing the movements.

For the majority of Christian believers, this general evidence is sufficient, and the confidence they repose in it is amply justified by the principles of inductive logic. The tree is known by its fruits. The fruits of Christianity abound on every hand in the noble characters and the beneficent institutions of Christian civiiization; while the adaptation of Christianity to the wants of the individual soul is so perfect that it cannot well be explained in any other way than on the theory of its truth. An insatiable hunger of the soul drives men to the acceptance of Christianity as starving men are led to welcome provisions for their bodily nourishment. In the case of Christianity the testimony of successive generations to its fitness for satisfying their spiritual hunger is evidence of the highest order.

In the practical presentation of Christian evidences, 
therefore, too much weight cannot be given to those facts which deepen in men their sense of $\sin$ and of dependence upon divine care. Under the influence of these facts the mind is stimulated to see and appreciate the wonderful adaptation of Christianity to human want, and to recognize the stamp of truth which lies in this fact of adaptation. It is therefore correct to say that the conviction of the truth of Christianity begins with the religious experience of the church. The conviction of its truth by those who have experienced its saving power is like that of a starving man whose hunger has been satisfied by appropriate food. Not only does he have a conviction, resting in his own experience, that this food was designed to meet his want, but he is able to transmit the evidence which he has obtained through experience to others who are feeling a similar want.

But, to those who wish to follow up these lines of evidence to their source, the means are readily at hand. and the process is as truly scientific as that which is pursued in any of the inductive sciences; while the conclusiveness of the evidence is such as cannot be denied by any one who gives it adequate and candid attention. For we find no break in the continuity of the historical evidences of Christianity until we reach the early part of the second century, or to a point of time 
which is separated from the crucifixion of Christ by less than one hundred years. Up to this point no one would now have the hardihood to deny that the New Testament, substantially as we have it to-day, has been universally regarded by Christian believers as genuine and authentic. It was made the basis of comment and instruction, in exactly the same way, by Origen, Tertullian, and Clement of Alexandria at the beginning of the third century, and by Irenæus in the last quarter of the second century, that it is by Christian teachers at the present time. The four Gospels were the sole source from which Justin Martyr, in the middle of the second century, drew the facts with which he endeavored to convince the Roman emperor of the importance and truth of the Christian system; while, by a remarkable series of recent discoveries, we have had brought to light the fact that the long-lost "Diatessaron " of Tatian, prepared by a pupil and companion of Justin Martyr about the middle of the second century, is nothing else than a harmony of the four Gospels, such as is prepared at the present time for the convenience of the Christian public. In the light of these discoveries there is now no one left to challenge the statement that the four Gospels substantially in their present form were, at the very beginning of the second century. recognized as the sole depository of the facts of Christ's 
life which have been the basis of his developing system of truth.

As a scientific problem the question is, to determine how at so early a date such a peculiar literature as is found in the New Testament could come into existence, be so widely accepted, and secure such controlling influence over so many companies of men scattered over the entire Roman Empire. For a determination of this question, we have as a basis our general knowledge of the weaknesses of human nature and the limitations of the human mind, which enables us to perceive the extreme difficulty, if not impossibility, of producing such a literature and giving it such influence at the beginning of the second century, except it were a record of actual facts and a revelation of heaven-born truth. The beauty, the pathos, the sublimity, of the portraiture of Christ given by the four evangelists is readily perceived to surpass all products of the merely human imagination; for it is easily seen that no subsequent artists have ever touched that picture except to mar it. So convincing are the lineaments of this portraiture, that it draws from unbelievers, as well as believers, such expressions as those of Napoleon:-

" 'I know men, and I tell you that Jesus Christ is not a man.

" Superficial minds may see some resemblance be- 
tween Christ and the founders of empires, the conquerors, and the gods of other religions. That resemblance does not exist.'

" "I see in Lycurgus, Numa, Confucius, and Mahomet merely legislators. . . . But it is different with Christ. Everything about $\mathrm{Him}$ astonishes me; His spirit surprises me, and His will confounds me. Between Him and anything of this world there is no possible term of comparison. He is really a Being apart. His ideas and $\mathrm{His}$ emotions, the truth which He announces, His method of producing conviction, can be explained neither by the organization of man nor by the nature of things.' ",

" " His gospel, the uniqueness of this mysterious Being, $\mathrm{His}$ appearance, $\mathrm{His}$ empire, $\mathrm{H}$ is march across ages and kingdoms, all is to me a marvel, a mystery unfathomable: a mystery which I cannot deny, and yet which $\mathrm{I}$ am just as unable to explain. Here I see nothing of man. The nearer I approach $\mathrm{Him}$ and the more closely I examine Him, the more everything seems above me; everything continues great with a greatness that crushes me.'"

" Christ speaks, and henceforth generations belong to Him by bonds more close, more intimate than those of blood, by a union more sacred, more imperious than any other union beside. He kindles the flame of a love which kills out the love of self, and prevails over every other love. Without contradiction, the greatest miracle of Christ is the reign of love.' '

". What an abyss between my profound misery and 
the eternal reign of Christ, proclaimed, worshiped, beloved, adored, living throughout the whole universe." " 2

Or of Rousseau, who exclaims :-

"If the life and death of Socrates were those of a sage, the life and death of Jesus are those of a God. Shall we suppose the evangelical history a mere fiction? Indeed, my friend, it bears no marks of fiction. On the contrary, the history of Socrates, which no one presumes to doubt, is not so well attested as that of Jesus Christ. Such a supposition, in fact, only shifts the difficulty without obviating it; it is more inconceivable that a number of persons should agree to write such a history, than that one should furnish the subject of it. The Jewish authors were incapable of the diction, and strangers to the morality contained in the gospel. The marks of its truths are so striking and inimitable, that the inventor would be a more astonishing character than the hero.":

The theory that the life of Christ given us in the four Gospels is the work of imposition, either on the part of the actors or of the historians, is too incredible to demand attention in these times. Nor does the theory of delusion, in its various forms, stand any better chance of passing the scientific tests. The general acceptance of the four Gospels in the early part of the second century stamps them as substantially contemporary documents. They could not have been received so generally, and made the basis of Chris- 
tian life in such widely separated communities, at that time, except they had come down with the imprimatur of the preceding generation, which was contemporary with that of Christ. In so brief a time it is impossible that there should have been any material legendary accretions or mythical growth incorporated into such a narrative of facts. As it is not an easy thing for an apprentice to improve upon the works of such masters as Raphael and Michael Angelo, which he could not touch but to reveal the work of his own bungling hand, so it would be practically impossible for any one to make additions to the inimitable narratives of the Gospels without betraying his human limitations. To take a single case: it would seem well-nigh impossible to invent or imagine an account of the conception and birth of Christ so appropriate to his subsequent history as that which is found in the Gospels. It has no resemblance to anything else that is found in literature. As a record of actual fact, it is in harmony with everything else related of Christ. He is a very bold dogmatician who would assert that the beauty and harmony of this conception is within the reach of the human inagination.

More tangible illustrations of the freedom of the New Testament from the legendary accretions of later times may be found in the accuracy with which it re- 
Hects the known conditions of the first half of the first century, in which the events purport to have occurred. The political, geographical, and sociological conditions of that period are so peculiar, and so sharply separated from those which followed the destruction of Jerusalem, that literature originating in the last portion of the century could not have simulated the conditions of the earlier part of the century so perfectly as does the New Testament.

There is no reasonable doubt that the first three Gospels were written before the destruction of Jerusalem, nor indeed that the Fourth Gospel was written by one who studiously clung to a statement of facts that had become firmly fixed in form before that event. ${ }^{4}$ The only theory left, therefore, for the origin of the Gospels, except that which assumes their truth as history, is that the contemporaries of Christ were deluded by their excited imaginations; and this, indeed, is the theory which is now being urgently pressed upon the attention of the public. But the more one emphasizes the ecstatic state of mind which it is supposed would follow the depression caused in the minds of his disciples by the betrayal, the crucifixion, and the death of Christ, the more improbable does it become that such sober-minded narratives should be the product of that ecstasy. The mysterious silence of the Gospels concerning the most 
of the period between the resurrection and the ascension is incredible on any theory but that of truth of the narratives. Most certainly the imagination of the writers was not given a free field in the matter. The general sobriety and practical wisdom which characterized the disciples after the reputed resurrection and ascension of their Lord are anything but characteristic of such ill-regulated excitement as must have followed mental delusion.

Viewed from every point, the Gospels have all the marks of true history, whose statements can be received without question. The origin of Christianity through any theory of fraud or delusion involves the supposition of a greater violation of the laws of nature than does the supposition of its origin through the facts as recorded in the New Testament. It is a more incredible supposition that crafty or deluded men should rise to the capacity of forging the character of Jesus and setting him in the position he occupies in history than that God should have condescended to reveal himself through man as he is believed to have done by the Christian church.

The existence of such a firm historical basis for the foundation of Christianity prepares us of itself to find true history in the preliminary stages of the divine plan of salvation. It is but natural to expect that He who 
in these last days has spoken to the world through his Son should in earlier times have spoken through holy men and prophets, and have made in the history of his chosen people the needful preparation for the culminating results. This expectation is fully realized upon observing the esteem in which the Old Testament was held by Christ and the writers of the New Testament.

THE OLD TESTAMENT INDORSED BY THE NEW.

At the beginning of the Christian era, the Pentateuch was generally regarded by the Jews as authentic history, and Moses was believed to be the responsible author of it. In the words of Professor Toy, one of the most radical critics of Old Testament history, "Nobody at that time doubted that Moses wrote the Pentateuch." The references of the New Testament writers, therefore, to "the law of Moses," "the book of Moses," "the writings of Moses," etc., had a definite significance. 'The only way of evading the force of the testimony of these direct references to its Mosaic authorship is either to challenge the competency of the New Testament writers to form opinions upon the subject, or to assert that their language is accommodated to the usage of the times, and so has no critical significance.

Both of these methods are freely resorted to by certair 
classes of critics. By some it is confidently asserted that the apostles are not competent instructors in the interpretation of the Old Testament. But of this view we will not pause to speak further, except to lament the unguarded remarks which have been made to this effect by many recent writers whom we are glad to reckon both as eminent scholars and as serious inquirers after the truth. Whether the force of the testimony of Christ and the apostles to the Mosaic authorship of the Pentateuch can be evaded by the theory of accommodation must be determined by examining the testimony itself.

In view both of the general belief of his times respecting the Pentateuch and of its own claims (of which we shall presently speak), it would seem that nobody can reasonably deny that there is convincing force in those passages which refer to the offering that "Moses commanded" (Matt. viii. 4 ); to the scribes and Pharisees who sit "on Moses' seat" (Matt. xxiii. 2); to one of the commandments which "Moses said " (Mark vii. IO); to Moses and the prophets "as witnesses of such weight that one rising from the dead would not be superior to them" (Luke xvi. 29, 3I); to circumcision as a law which "Moses had given" (John vii. 22, 23); and to divorce as permitted by a precept which "Moses wrote" (Mark x. 2-5). 
In view of the usage of language in Christ's time, it seems, also, much like an unworthy subterfuge to say that, when (as in Mark xii. 19, 26; Matt. xxii. 2332; Luke xx. 27-38) Jesus refers to a passage which he says they have "read in the book of Moses, in the place concerning the bush," he meant not a book written $b y$ Moses, but a book written about Moses. This impression is strengthened by the fact that, in the immediate connection, the Sadducees, whom Christ was addressing, introduced one of their questions by saying, "Master, Moses wrote unto us," etc. Finally, in John v. 45-47, Christ says expressly, "Moses wrote of me," and refers to the "writings of Moses," which, if they understood and believed, would rebuke their unbelief concerning him. There can be no reasonable question that in this last passage Christ bears unequivocal testimony to the fact that there were well-known writings of Moses, and that an appeal to them was an appeal to Moses. Ordinarily this would be enough to determine what writings were meant.

But in the mode of his references Christ had made assurance doubly sure. For what are the writings of Moses which the Jews regarded as prophetic of Christ? They are those which contain such passages as the ones which speak of the seed of the woman as destined to bruise the serpent's head (Gen. iii. 15); of the seed of 
Abraham, by which all nations of the earth were to be blessed (Gen. xii.); of the Shiloh unto whom shall be the gathering of the people (Gen. xlix. Io); of the Star out of Jacob, and the Scepter that shall rise out of Israel (Num. xxiv. 17); of the great Prophet whom God will raise up, and unto whom the Jews should hearken (Deut. xviii. I 8); and, finally, of the serpent in the wilderness, which Christ himself interpreted as pointing to himself (Num. xxi. 9; John iii. It). Now these are from all the parts of the Pentateuch into which the critics have arbitrarily divided it.

Did space permit, much might be added from the writings of the apostles, where both their direct references and their numerous lines of argument are based on the assumption that the statements in the Pentateuch concerning the sacrifices, the tabernacle, the priests, and the general history of the wanderings in the wilderness are true. It should also be borne in mind in all this discussion that it is the truth with which we have most concern. But it is hardly fair to say that, if the history contained in the Pentateuch is true, it is not much matter when it was written, since the truthfulness of the Pentateuch implies that it is a product of the Mosaic age. For certainly, if, as a Jewish writer has recently observed, the book was written near enough the time of Moses to be authentic history, and yet not by 
Moses, then it is a forgery which was fraudently passed as a Mosaic production; while if, as so many critics now maintain, it originated by the embellishment of old traditions several hundred years after Moses, then its history is of no account, and it is both false and fictitious.

We need not pause to dispute the position held by some, that the historical parts of the Pentateuch are, in the main, true, although they were preserved only through oral tradition for many centuries. For however much we may exaggerate the powers of memory in primitive man, it is hardly to be supposed that it could transmit with accuracy prosaic facts through an indefinite number of generations. Besides, the superabundant evidence we now have of the prevalence of writing on tablets of clay (the most enduring of all material) for thousands of years before the time of Moses, and preëminently among the nations with whom Israel came in contact, renders it altogether probable that it was used by the Israelites. It would have been very strange if they alone should have trusted their history to memory, when they could so easily have preserved it on clay tablets. ${ }^{5}$

On turning now to the books which Christ's auditors understood him to refer to when he spoke of the "law of Moses" and of "the writings of Moses," etc., we 
find that almost every chapter of Exodus, Leviticus, and Numbers is said to contain things which the "Lord spake unto Moses," or which "Moses did according to all that the Lord had commanded him "; and that in Ex. xxiv. + it is said that "Moses wrote all the words of the Lord," referring at least to the three or four preceding chapters; and in Ex. xvii. It that Moses was commanded to "write" certain things for a memorial in a book; and that, again, in xxxiv. 27, Moses was commanded to "write" certain other things; while in Deuteronomy we find that more than nine-tenths of the matter professes to proceed directly from the mouth of Moses; and in xxxi. 9 it is said that "Moses wrote this law, and delivered it unto the priests," and in verse 10 that he left commandment that it should be read every seren years in the ears of all the people and, finally, in verses $24-26$, we are told that when "Noses had made an end of writing the words of this law in a book," he said to the Levites, "Take this book of the law, and put it by the side of the ark of the covenant of Jehovah your ( ness against thee."

Such, in brief, is the testimony of the New Testament to the Mosaic authorship of the Pentateuch. Granting that this may possibly be rebutted or set aside. still it remains true that the burden of proof lies with 
heavy weight upon those who would explain it away, and we may properly ask of them to produce the very best of evidence, and, as their evidence must be all circumstantial, we can demand of them that it be that which is unequivocal, and which does not yield as ready explanation in accordance with the strong, direct testimony adduced, as in accordance with the theory that discredits the direct testimony. We have a right in all equivocal cases to claim for the well-accredited witness the benefit of whatever doubt may exist. To do otherwise is to fly in the face of the fundamental laws of evidence, and to abandon all just claims to scientific: procedure. 
CHAPTER II.

\section{MIDDLE AND LATER JEWISH HISTORY.}

THERE are different ways of writing history. Indeed, history may properly include every variety of literature, and has a right to the use of all forms of speech and all figures of rhetoric. Historical language, like every other kind, can claim the benefit of fair interpretation. The late Professor Stubbs insisted that no historian could tell the truth when writing in the style of Macaulay. The difficulty was that so prosaic a writer as Professor Stubbs did not know how to interpret that more rhetorical style which is designed to make an adequate popular impression.

Even the ordinary affairs of life can be truthfully described in such opposite ways that they seem to be contradictory. A tornado or a lightning stroke is correctly described, either as the result of the operation of natural forces which can be scientifically investigated, or as the result of a divine purpose of Him "who maketh his angels winds, and his ministers a flame of fire." This is but the statement of a well-known legal principle, that a person is properly said to do whatever he accomplishes through his agent. In a military cam- 
paign, glory is equally distributed between the commander-in-chief and the army in all its organizations. And so, in all the affairs of the world, no amount of emphasis upon the secondary causes need obscure the agency of the divine mind which controls and orders them.

Did we not have so many lamentable illustrations of the fact, it would seem impossible that learned men of great discernment in other respects should be misled by the anthropomorphic elements in Old Testament history. History can be told in poetry as well as in prose. Much of Old Testament history, indeed, is incorporated into the hymns we sing. Ordinarily the common sense of mankind is better able to judge the poetical garb, and interpret the rhetorical figures, than: is the learning of critics whose studies have limited them to a narrow line of investigation.

In Milton's version of the One Hundred and Thirty-sixth Psalm, it would be childish to impute to him either scientific or historic error, by reason of the various figures of speech through which, with the psalmist, he traces all of the phenomena of the history of the world directly to the agency of God. We can permit him to sing, and indeed, without compromising ourselves, sing with him, those noble phrases ascribing praise to the Lord,- 
" [Who] caus'd the golden-tressed sun, All the day long his course to run;

The horned moon to shine by night, Amongst her spangled sisters bright."

"His chosen race he did bless, In the wasteful wilderness.

In bloody battle, he brought down Kings of prowess and renown.

He foil'd bold Seon and his host That rul'd the Amorrean coast;

And large-limbed $\mathrm{Og}$ he did subdue, With all his overhardy crew."

"All living creatures he doth feed, And with full hand supplies their need."

In the words of the devout Keil, when commenting on Joshua x. 12-14,-

" [When] Isaiah prayed to the Lord in the name of his people, ' $\mathrm{O}$ that thou wouldest rend the heavens and come down, that the mountains might flow down at thy presence,' etc. (Isa. lxiii. 19); or when David sings, 'In my distress I called upon the Lord, . . . he bowed the heavens also and came down, . . . he sent from above and took me, he drew me out of many waters' (Ps. xviii. 7-I7); who is there who ever thinks of understanding their words literally, as denoting an actual rending of the heavens, or a desire that God 
would actually descend from heaven and stretch out his hand to draw David out of the water? Undoubtedly the idea of a fearful storm accompanied by earthquake has furnished materials for the imagery of the eighteenth Psalm; but it is as clear as day that the striking figures, which it contains, are not fully explained by referring them to an earthquake and storm."

In all these figures of speech there are underlying facts which, in some of their aspects, are correctly stated. The historian who fails to recognize the hand of God underneath the secondary agencies of history sees but a part of the truth, and that the smaller and more unimportant part. We are familiar enough in these days with the statement that the Old Testament was written for a purpose, and that that purpose was religious. With this principle we have no reason to quarrel. But from many of the applications of it we have much reason for dissent. To the assumption, more or less clearly made, that literature written for a purpose can convey no substantial nucleus of facts, we do object in the most emphatic manner. At the same time it must be affirmed that the discernment of the general purpose of a writer is of great assistance in the interpretation of his language. To make the proper impression, certain phases of the truth must be emphasized, or, what is the same thing, thrown into apparently 
disproportionate prominence, to the neglect of other phases, which are equally true, but for the occasion not equally important.

Both the difficulty and the importance of giving proper emphasis, through language, to the main object which it is desirable to accomplish, are well illustrated in the art of cartography. Our government mapmakers are busily engaged in recording, in visible form, the results of the geodetic surveys. After going over the field with their accurate triangulations, to determine the contours of the surface of an area, the surveyors present their notes to the cartographer. To their surprise, the surveyors often find that the map-maker habitually exaggerates certain features in the results of the survey. The contour lines are indeed there, but they occupy a breadth upon the map which is many times larger than, in strict proportion, it should be. All the gorges and valleys and mountain ranges are delineated upon the map wider than they really are.

When the cartographer is confronted with this fact, he replies, "Why, my dear sir, if I should endeavor to represent the vertical and the horizontal lines of measurement in their strict proportions, you could not see the contours at all. You would be more misled by an attempt to draw things as they actually are, than you are by the exaggeration, which enables you to really 
see something, and trusts your imagination to correct the apparent error by a sober second thought."

And so it is in all attempts at delineating natural scenery through the art of drawing or painting. A photograph of a distant mountain, while giving the exact truth, deceives one as to the real impressiveness of the scene. The skillful draughtsman makes a proper impression by omitting innumerable details, and throwing into relief the main object under consideration. The classic painters of the Western world give perspective to natural scenery by correctly representing the apparent diminution of distant objects in their impression upon the eye, owing to the diminished angle of vision, and by deepening the color, which, in nature, is the result of the greater depth of atmosphere through which distant objects are seen. The Japanese, on the other hand, very effectively and skillfully give perspective to their pictures by enlargement of the distant mountain scenes, which is the exact opposite of the impression made upon the senses. Their excuse for this is that they paint as they feel, and not as they see. And why not? The painter, like the poet, has his appropriate license. We do not charge Raphael with either ignorance or falsity when he paints eleven sturdy apostles fishing from a boat which is scarcely larger than a child's toy. It was not his purpose, in the painting, 
to represent all he knew about the boat; and so that could be represented conventionally, as we say, and nobody but an ignoramus either complains of it or misunderstands it. Indeed, the highest art of pictorial representation is found, not in those pictures which represent in minutest detail every accessory of the scene, but in those which concentrate attention upon the main point, and leave the rest in the comparatively indistinct background.

These principles are especially applicable to those condensed historical statements and descriptions of natural phenomena which characterize the early portions of the Bible. The obvious purpose, for example, of the first chapter of Genesis, was to impart not scientific but religious truth, and to do this in such concise and striking form that it could be easily appropriated and retained by men of all classes and ages. of all stages of culture. It is one of the most astonishing literary phenomena in all the world that this end has been accomplished without violence to the principles of later scientific discovery.

Again, the object of the brief history of the human race from the creation to the time of Abraham, covering a period of unknown thousands of years, was likewise religious, serving to give us a brief conspectus of events which should so unfold the depths of human nature. 
and the general plan of God's dealings with it, as to prepare us properly to appreciate the more definite history of redemption which begins with Abraham and ends with Christ. Professor WVilliam Henry Green has done a service for biblical criticism which is as yet by no means properly recognized, in showing that, in accordance with the usages of Hebrew literature, and with the evident special purpose of its introductory portions, the genealogical tables in the fifth and tenth chapters of Genesis were not designed to teach, and do not teach, a definite chronology: they serve simply to throw emphasis upon the direct line of descent, without shedding any definite light upon the length of that line. ${ }^{1}$

All history is fragmentary. The story of no event is ever fully told. The omission of details in one parallel account which are not found in another is not necessarily significant. The statement of a biblical historian need not be regarded with incredulity simply because it stands alone. It may be true though not distinctly confirmed by other witnesses. To assume, as many do, that biblical statements are to be disregarded except when directly supported by other documents is a most unscientific procedure.

With these preliminary cautions, we will now, preparatory to the further discussion of the earlier por- 
tions, which will form the principal subject of our study, briefly consider some of the more striking facts which give an air of reality to the later part of Bible history.

CONNECTING LINKS OF THE ARGUMENT.

To determine the character of the earlier historical documents of the Bible, and to prepare our minds for their proper appreciation and interpretation, we shall find it helpful to trace backward the history of Israel through its later and middle portions, where we have fuller opportunities to compare the record with contemporary documents; thus giving us a wider basis for the formation of general conclusions concerning its trustworthiness. For, whatever may be said about the fragmentary character of the documents preserved in the Old Testament, they have been arranged, by no ordinary skill, to form a unity that is remarkable. The sagacious ability with which the final editors of the Old Testament have selected their material, and preserved only such as is either demonstrably in accordance with the facts as known from other sources, or such as could readily be adjusted to such facts without doing violence to their necessary implications, gives to them a high place as historical authorities, and leads us, unless we have evidence to the contrary, to accept as trustworthy what they have transmitted to us. In 
other words, our attitude of mind should be one of confidence, rather than of agnosticism or distrust. The burden of proof falls with great weight upon those who challenge documents so authentic as these of the Old Testament seem to be."

In moving, then, backwards, along the line of Old 'Testament records, towards the origin of the Israelitish nation, and towards the original fountain of hope both for Israel and the world, it will be our aim to show that it is not easy to escape the conviction that we are continually in the realm of genuine history, surrounded by real persons, and dealing with real sociological and political developments. The story of the return of the Jews to Palestine after their long captivity in BabyIonia, the rebuilding of the temple, and the separation between the Jews and the Samaritans, so accords with the great historical movements of that time and place as they are made known through other and independent channels of information, that its truthfulness cannot easily be doubted. The existence of the little remnant of Samaritans at Nâblus, with their Pentateuch and their devotion to their worshiping-place upon Mount Gerizim, is a fact meeting our eyes to-day which has no explanation, except in connection with some such occurrences as are narrated in the concluding historical books of the Old Testament; while the return of a 
selected remnant of Jewish captives accords so perfectly with the political changes now known to have taken place in Babylonia at that time, that one can but find it difficult to discredit the account or believe it to be anything but genuine history.

HISTORICAL SETTING OF THE BOOK OF DANIEL.

According to all contemporary accounts, there was in Babylon a change of policy with the change of dynasties ushered in by Cyrus. The new policy was one of religious toleration. We need not, indeed, go sc far as to suppose that Cyrus was a monotheist or a follower of Zoroaster. He was likely a polytheist, anc as such recognized the Jews, and granted to them their privileges of belief. Upon the clay cylinder of Cyrus describing the capture of Babylon, it is definitely stated that it is his policy to honor and protect all the gods of the various peoples that come under his rule, and to restore exiles to their original dwelling-places. "All of their peoples" (that is, of the captive and dethroned deities), he says, "I gathered together and restored to their own dwelling-places." Likewise it fell in with the plans of Cyrus, as a far-seeing statesman, to restore Palestine to its condition of original prosperity, and to establish in it a people having such reason to be loyal to himself that he might trust them as a bulwark 
against the encroachments of Egypt, and as allies in the contemplated extension of his dominion over the valley of the Nile. ${ }^{3}$

This general conformity of the biblical account to the political conditions of Babylonia at that time, brought to light by recent discoveries, is evidence strong enough to dispose of almost any amount of petty objections arising from minute apparent discrepancies in chronology, or differences in names applied to the same person; for these objections might all easily disappear upon a complete restoration of the history.

In the book of Daniel, likewise, we find ourselves moving, so far as we can verify the statements, in a most remarkable environment of historical reality. The scenes which are brought before us are perfectly in accord with the manners and customs of the people, and with the characteristics of the dynasties to which they relate. In this respect they bear the marks of a contemporary document. So great were the changes which took place between the earlier parts of Daniel's career and its closing scenes, that we may pronounce it a literary impossibility for fiction of any sort to have so perfectly simulated the facts of the time as does the historical part of the book of Daniel. The objections which are made to its historical character are almost wholly based upon repugnance to the admission of mir- 
acles into the circle of our beliefs, or to an undue magnifying of small apparent discrepancies which can be easily explained away. As to the miraculous events, they are not of a character to have been noticed by the national historians of Babylonia; and whether they are too improbable to be believed will depend entirely upon the importance of the religious crisis which had then come to the Lord's chosen people. We should therefore have to discuss that question upon general principles, which we cannot well delay to do here.

Limiting ourselves to one of the most striking and apparently improbable statements, we note that the account of Nebuchadnezzar's abasement given in the book of Daniel proves, in the light of modern medical science, to be strictly in accordance with the probabilities connected with a certain form of mental disorder. As is shown in a learned article by Dr. Merrins, ${ }^{4}$ it was a case of melancholia, such as is quite likely to affect a man of his character; for this disease, like death, loves a shining mark. As appears both from Scripture and monumental records, Nebuchadnezzar was a man of immense intellectual power and of marked religious devotion. But his successes, both in foreign conquests and in the development of all the interests of Babylonia, coupled with his autocratic power, appear to have made of him a megalomaniac. At the zenith of his power he 
frequently gave way to terrible outbursts of passion, as in his treatment of the wise men of Babylon who were unable to interpret his dream, and in his consigning Shadrach, Meshach, and Abed-nego to the fiery furnace; while his growing spiritual pride exhibits itself in setting up an enormous golden image (probably of himself) on the plain of Dura, and commanding every one to worship it. The climax of his spiritual pride appeared in his exalting himself against the Most High, and openly expressing the conviction that "all this greatness and glory had been won by the strength of his own right arm." "Is not this great Babylon, which I have built for the royal dwelling-place, by the might of my power and for the glory of my majesty?" As is natural in such cases, it was from the summit of self-exaltation that he plunged into the depths of despair. The results which followed are by no means uncommon. During these periods of depression, the victim of melancholia frequently withdraws himself from the world until " at last he sinks into a state of stolid stupor, is wholly absorbed in his mental agony, is confused as to his personal identity, neglects to eat, and is careless and dirty in his appearance and habits." His eating grass and suffering the hair and nails tc grow give a vivid impression of the depth to which his melancholia had driven him. 
Also, according to Dr. Merrins:-

"As to restoration to sanity, the prognosis in cases of melancholia is favorable, much more so than in any other form of insanity. A majority of the patients recover, even at an advanced age and after years of the most intense mental disorder. And recovery is often so very complete, that the highest and most active brain work is performed; and so permanent, that a relapse never occurs during a long subsequent life. In some cases the recovery is gradual; in others the malady disappears suddenly and mysteriously. Of one patient it is recorded that, after standing like a veritable statue of woe for fifteen months, neither speaking, nor eating, nor allowing anything to be done for him, he suddenly became mentally alert, conversed freely, and thereafter remained quite well for over twelve years. Another was in an insane asylum for thirty-four years. For fifteen years he sat with his head bent upon his chest, apparently regardless of everything about him. One evening, while sitting in the billiard-room without taking any interest, he suddenly began to look about him; a few days after he was cheerful, in fact almost exuberant, and it was not long before he was completely cured."

"Neither is the king's remembrance of the circumstances of his degradation and of the causes which led to it very remarkable. Patients on recovery are often able to tell what was their mental state immediately prior to their madness, and some are able to describe the whole course of their disease with its various delusions. 
Nebuchadnezzar knew his reason had been dethroned, and why the judgment came upon him, and after his recovery he was a better man. As in the case of King Lear of the dramatist, the madness has been purgatorial."

It is hardly possible that such a description of the career of this great monarch as we find in the book of Daniel should have been a legendary accretion by which the real facts are embellished. The description accords so well with the natural development of the disease that it is difficult to believe it to be anything but a simple record of well-known facts. ${ }^{5}$

Two of the apparent historical discrepancies in the book of Daniel have had so much light shed upon them by recent discoveries, that they have come to be an argument for the credibility of the book, rather than against it.

In the book of Daniel, Belshazzar is said to be the king, and Nebuchadnezzar is repeatedly referred to as his father; whereas, according to the monuments, Nabonidus was king. But we find upon the monuments numerous inscriptions of Nabonidus in which Bel-shar-uzur is referred to as his eldest son, his offspring, who was associated with him in various transactions, and frequently put forth as his representative wherever the king himself was absent. 
But it is by no means improbable that, as prince regent, he would be called king for an indefinite period before his father's death. For, thus Jehoram was appointed by his father Jehoshaphat king of Judah seven years before his father's death ( 2 Kings i. 17 and viii. I6) ; while Jotham was in similar manner made king of Judah before his father Uzziah had died of leprosy, though Uzziah is still called king in some of the references to him. It is thus, that, in a loose way, Nebuchadnezzar may have been called the father of Belshazzar, though he may have been his grandfather, or only his predecessor on the throne. It is significant that, in the descriptions on the monuments of Shalmaneser II., Jehu, the extirpator of the house of Omri, is called the son of Omri. From this we learn, or should learn, that, according to Oriental usage, the phrases describing Belshazzar's relations to Nebuchadnezzar need signify no more than that he was a successor.

It should be noted, also, that nothing is said in the book of Daniel about the place of Belshazzar's feast. It probably was at Babylon, but it may not have been. Nor is anything stid about the manner in which Babylon was captured. The doubtful statements upon these points are those which were made by the Greek historians. The simple statement that Darius the Mede 
received the kingdom must for the present be accepted upon the unconfirmed authority of the sacred historian. That it is not historically true has by no means been proved, and it is incapable of proof without our knowing very much more about the events of the period than we now know from outside sources.

The persistent efforts made by many to fix upon the book of Daniel a serious historical error in saying that after the death of Belshazzar "Darius the Median took the kingdom" (Dan. v. 3I), all proceed upon the supposition that biblical statements not positively confirmed by outside evidence are to be regarded as disproved. But, upon examination, the negative evidence in this particular case is very far from conclusive. For, the time which elapsed between the accession and the installation of Cambyses as king of Babylon is, according to the monuments, but one year. If Darius the Mede was in power for that time (and the Bible mentions but one year), it is not strange that no record of it has yet been found among the inscriptions, since, at Professor Robert Dick Wilson has noted, "out of the ten years of the contemporaneous reigns of Cyrus and Cambyses only three tablets containing the names and titles of both have been found,--one from the first year (so called) of Cyrus, and two from the first year (so called) of Cambyses. How could we expect to find one 
from the four-months' reign of Belshazzar and Darius the Mede?"

Furthermore, as, according to the Annals of $\mathrm{Na}$ bonidus, Gobryas was governer of Babylon on the third of the eighth month, and Cambyses on the fourth of Nisan in the following year, it is plausibly main. tained by Pinches, and other scholars of highest note. that Darius the Mede of the Bible was probably the same as Gobryas of the monuments. With present light it is certainly impossible to prove the contrary. Still further, it is ably maintained by Professor Wilson that the word "Darius" may be a translation of the foreign word Gubaru; or perhaps the word "Darius" is from a Persian word meaning "king," and so was not a proper name in the strict sense of the word; or possibly the individual here called Darius had two names, as did Rameses, Solomon, Artaxerxes, and Darius Nothus, each of whom was sometimes designated by another name. Again, in the Annals of Nabonidus, Gobryas is said to be the governor of the land of Gutium, which lay at the foot of the pass from Ninevah to Ecbatana, the capital of the Medes. He would, therefore, very properly be called a Mede.

But the supposition that Gobryas and Darius are the same is not by any means the only one which might remove the apparent discrepancy. Those who wish to 
examine the matter farther will find it fully discussed by Professor Wilson in the Appendix."

But these difficulties, being chiefly those of interpretation, and being such as arise from our ignorance of the larger part of the facts connected with the history, should count lightly in offsetting positive statements which in general are found closely to conform with the known conditions. It certainly counts for more than many writers are willing to admit, that this bold statement in Daniel that Belshazzar was king should be found supported by the monuments, which bring out the fact that Belshazzar, though so young and not himself sole king, was endowed by his father with the royal privileges, and so could properly receive the title; and that the statements concerning Darius the Mede are not positively contradicted, but are so easily made to fit in to the general outline of the history.

THE DESTRUCTION OF SENNACHERIB'S ARMY.

Passing backwards to the time of Hezekiah, we come to the remarkable account of the invasion of Palestine by Sennacherib, and the opportune destruction of his army, on the plains of Philistia, before it had reached Jerusalem. The historical character of the account of this invasion given in Kings and Chronicles, and its disastrous conclusion, while not directly corroborated 
by contemporary Babylonian documents, is in the strongest manner indirectly supported both by them and by many general considerations. The Assyrian army on its way to Egypt was delayed on the unhealthful shores of the Mediterranean for the siege of Lachish and Libnah (2 Kings xviii. I4), and it was there, as would be most likely, that the catastrophe occurred.

"The great highway of commerce and war between Asia and Africa, after leaving Gaza, the most southern Philistian city, passed near various salt marshes along the coast, the largest of which was known as the Serbonian Bog; from there the road passed to Pelusium and the delta of the Nile. The natural conditions of a hot, humid climate, and great stretches of mingled salt and fresh water, were such as to favor the development of any epidemic, and so also was the miserable condition of the people. "The Serbonian Bog was surrounded by communities of salt-makers and fishcurers: filthy villages of under-sized and imbecile people who always had disease among them.' 'It is not surprising, therefore, to find that armies passing through this region were nearly always decimated by pestilence.' 'It was here that . . . in Justinian's time, the plague started more than once a course right across the world; here a Crusading expedition showed symptoms of the plague; here in I799 Napoleon's army was infected with the very fatal fière ì bubons, and carried the disease into Syria, while the Turkish force that marched 
south in 1801 , found the plague about Jaffa and in the delta." " ${ }$

In the very brief description of the biblical writer, the agency of the Lord is given prominence, though even then it is through an angel that the destruction is said to have been accomplished. In view of recent discoveries concerning such plagues as may reasonably be supposed to have been the immediate cause of the destruction of Sennacherib's army, over whom

"The angel of death spread his wings on the blast, And breathed on the face of the foe as he passed,"

the references to the event by the profane historians are peculiarly interesting. Josephus attributes the catastrophe to a plague, "a pestilential distemper" sent upon the army. ${ }^{\text {s }}$ Recent medical authorities recognize it as the bubonic plague, with which we have lately become painfully familiar. One reason for thus assigning it is to be found in a curious statement of Herodotus," that rats and mice played an important part in the tragedy. According to him, "field mice poured in upon the Assyrian army, devouring their quivers and their bows and the thongs of their shields, so that, on the next day, when they fled, bereft of their arms, many of them fell." It is a striking confirmation of the truthfulness of all these records, that, in the recent epidemucs of the bubonic plague in India and China, 
it is found that they are characterized by an enormous exodus of rats, which are supposed to convey the contagion.

Again quoting Dr. Merrins,-

"It is now well known that many of the lower animals, especially rats, and mice, and other rodents, and the parasites that infest them, are important agents in the propagation of plague, and die themselves in large numbers from it. Even before the plague attacks human beings, it destroys these animals. In one of the most important and ancient of Hindoo writings, the people are instructed to quit their homes, and go to the plains, as soon as they observe that rats fall from the roof above, jump about, or die. In the recent Chinese epidemic, masses of dead rats were seen in the streets of Hongkong, and at one gate alone, in the city of Canton, the keeper collected and buried no less than twenty-four thousand of these animals."

"As to the appalling mortality of over fifty thousand in the Philistian epidemic, and the death of one hundred and eighty-five thousand of Sennacherib's army. there need be little cavil. In the Justinian epidemic, a 'myriad of myriads' are said to have perished. In the European epidemic of the fourteenth century, twentyfive millions died. In the Great Plague of London of I665, about seventy thousand died. Six hundred thousand have died during the course of the present epidemic in India [1904], and it is still pursuing its dreadful course." 
'The suddenness of the destruction of the army described by the sacred writer, the liability of such epidemics in the region said to have been occupied by the army, as given both by Josephus and the sacred writer, and the incidental mention by Herodotus of what we now know is a natural accompaniment of the bubonic plague,-all serve to give an air of historic reality to this account, which is most impressive.

This explanation of the destruction of Sennacherib's army receives striking confirmation from the account given in I Sam. iv.-vi. of the plague which, several centuries before (about I IOO B.C.) attacked the Philistines in the same region when they hat possession of the ark. On that occasion the men were repeatedly smitten with "emerods in the secret parts" (v. 9), and great numbers died. One remedy proposed by the Philistines was to "make images of your mice that mar the land" (vi. 5)."1"

On comparing the Assyrian records of the period of Sennacherib with the biblical history, the air of reality in the biblical account is most strikingly confirmed, though there is no distinct reference to the disastrous ending of the campaign. In the Assyrian inscriptions, we are told that, in his third campaign, Sennacherib marched to the land of the Hittites, and passed on to the coast of Philistia, capturing numerous cities, and 
encountered the Egyptian army. But meanwhile "Hezekiah of Judah, who had not submitted to my yoke .... was shut up like a bird in a cage in Jerusalem, his royal city." But while mention is made of the capture of many of the minor cities of Hezekiah's kingdom, there is a significant silence respecting the capture of Jerusalem itself. It is noteworthy, also, that there is no hint in the Assyrian records of Sennacherib's having visited the western land during the twenty subsequent years of his reign. Thus, in the silences of the Assyrian inscriptions, we find ample opportunity for the occurrence of the disasters mentioned by both the sacred and profane historians who give us the other side of the story. Sennacherib does indeed mention that Hezekiah sent to him large tribute, - "thirty talents of gold and eight hundred talents of silver, great stores of lapis lazuli, couches of ivory, arm chairs of ivory covered with elephants' hide." This, too, is corroborative of the sacred account, which informs us that Hezekiah, in order to appease the Assyrians for having transferred his allegiance from them to Egypt, emptied the treasuries of his temple and the king's house, cut off the gold plate of the door posts of the temple, and sent thirty talents of gold and three inundred talents of silver to buy off Sennacherib. 
THE TIMES OF AHAB ANI JEHU.

Going back to the middle of the cighth century B.c., we again find, in the sacred recoris relating to the times of Ahab and Jehu, some of our most striking undesigned corroborations of their truthfulness. From the brief and fragmentary historical statements in the book of Kings, we learn that, about the middle of this century, the Northern Kingdom of lswel, under the lead of Ahab, was engaged in war witl the Syrians under the leadership of Ben-hadad ( 1 Kings xx.) in which the Syrians were ignominiously defeated in the plain near Aphek. Whereupon Ben-hadad, with a rope around his neck, appealed to Ahab for mercy, when, contrary to what would have been expected, Ben-hadad was not only treated mercifully, but generously. There was no demand made for the surrender of Damascus or for any other serious and humiliating conditions, but a treaty was entered into with the Syrians by which they became allies of Israel.

It is significant that shortly after this, at the battle of Karkar ( $85+$ B.c.), Ahab was found fighting side by side with Hadadezer (identical with Ben hadad) of Damascus, and a number of other allies, on the Mediterranean coast, against the Assyrian army urder Shalmaneser II. In this battle the Assyrians were victoriou. But the victory was evidently so nearly a drawn battle 
that the Assyrians did not make much further headway, for they advanced only so far as the Orontes River, when they turned back, and left the country unmolested for several years. Three years after, however, (see I Kings xxii.,) we find Israel again at war with Syria, fighting for the possession of Ramoth-Gilead, where Ahab was killed.

In these accounts, when dovetailed together, we find a remarkable confirmation of the truthfulness of the sacred records in the explanation which is given by them of the varying attitudes of Ahab toward the Syrrian king. As near neighbors struggling for contiguous territory, Israel and Syria were natural enemies. But as Ahab was not totally destitute of discernment, and presumably possessed some of the qualities of farseeing statesmanship, he could but see, in the rising power of Assyria, and in the movements of Shalmaneser's army towards the west line, the approach of a more formidable enemy than the smaller power could be whose capital was at Damascus. This most readily accounts for the leniency with which he treated Benhadad, and for the treaty which he made with him, an account of which is given in the book of Kings. A most natural sequel to this is the appearance of Ahab and Ben-hadad together upon the field of Karkar in a zartially successful attempt to resist the common enemy, 
who was approaching under the leadership of Shatmatieser; while the temporary success of their resistance, by relieving them for a period from the dangers of an Assyrian invasion, left Syria and Israel again to be the prey of their own petty jealousies, and prepared the way for the wars which followed so soon after. Such an undesigned adaptation between the accounts of the sacred writers and of the Assyrian inscriptions certainly gives an air of reality to that of the sacred writers which cannot easily be resisted.

THE BLACK OBELISK OF SHALMANESER II.

The undesigned coincidences in these records are continued in a remarkable manner in the accounts which are given of the later expedition in B.c. $8+2$, a partial record of which is found on the celebrated black obelisk of Shalmaneser II. According to the record on the monument, this great Assyrian conqueror in that year crossed the Euphrates for the sixteenth time, and in the course of his victorious career conquered Hazael of Damascus, and pursued him to his royal city, and shut him up while he devastated his territory as far as the mountains of Hauran on the one side, and to the sea at Beirut (Dog River) on the other. But while there is no mention of his fighting with the Tyrians, Sidonians, and Israelites, it is said that he received 
tribute of them, and "of Jehu the son of Omri." Now, as there is no mention in the sacred records of any defeat of Jehu by the Assyrians, nor of the paying of tribute by him, it is but the most natural thing that the tribute should have been paid under the conditions which are implied in the whole biblical account; for, in the period subsequent to the battle of Karkar, Damascus had turned against Israel, so that Israel's most natural method of humiliating the Syrian power was by making terms with, and paying tribute to. Shalmaneser II.

THE MOABITE STONE.

One of the most important monumental discoveries in giving reality to Old Testament history was that of the Moabite stone, which was set up by King Mesha (about 850 в.с.) to signalize his deliverance from the yoke which Omri, the king of Israel, had imposed upon him. The inscription upon this stone was valuable, among other things, for its witness to the civilized condition of the Moabites at that time, and to the close similarity of their language to that of the Hebrew. From it alone we learn that Omri, king of Israel, was compelled by the rebellion of Mesha to resubjugate Ioab; that, in doing so, he and his son occupied the cities of Moab for a period of forty years, but that it was restored to the Moabites in the days of Mesha, 
after a series of battles. Whereupon the cities and fortresses retaken were strengthened, and the country repopulated, while the methods of warfare were similar to those practiced by Israel. On comparing this with 2 Kings iii. 4-27, we find a parallel account, which dovetails in with this in a most remarkable manner, though naturally the biblical account treats lightly of the reconquest, simply stating that, on account of horror created by the idolatrous sacrifices of the king of Moab, who offered his eldest son as a sacrifice upon the wall before them, they departed from the land and returned to their own country.

THE EXPEDITION OF SHISHAK.

In the fourteenth chapter of First Kings we have a very brief account of an expedition of Shishak, king of Egypt, against Jerusalem, in the fifth year of Rehoboam. To the humiliation of Judah it is told that he succeeded in taking away the treasures of the house of Jehovah and of the king's house, among them all the shields of grold which Solomon had made; so that Rehoboan made shields of brass in their stead. To this simple, unadorned account there is given a wonderful air of reality when one gazes on the southern wall of the court of the temple of Amun at Karnak, and beholds the great mass of sculptures and hiero. 
glyphics which are there inscribed to represent this campaign of Shishak. One hundred and fifty-six 1 aces are enumerated among those which were captured, the northernmost being Megiddo. Among these places are Grza, Adullum, Beth-horon, Aijalon, Gibeon, and Jula-melech, in which Dr. Birch is probably correct in recognizing the sacred city of Jerusalem.

BREVITY OF THE BOOK OF JUDGES.

Going back to the book of Judges we reach a portion of Israelitish history in which we should expect little direct and positive scientific confirmation of the biblical story, since it is so local in its references, and is professelly so fragmentary. In giving the history (if a few biographical accounts can be called history) of four luundred years, nothing is said of more than half of the time, for the reason tiat it was made up of long periods of uneventful peace. "And the land had rest" is the sole record for forty years under Othniel, eighty years under and after Eluud, forty years after Deborah's victory, and forty years under Gideon. Such periods of peace are unusual in any people's history, and betoken the presence of most powerful conservative influences. That those influences proceeded from the law and the priesthood, whose establishment is recorded in the Pentateuch, is a most 
reasonable supposition. 'The way in which many biblical critics have endeavored to reverse the historical statements of the Pentateuch by appealing to negative evidence drawn from a history professedly so imperfect and fragmentary as the book of Judges is, is a travesty on the so-called inductive and scientific criticism of the Bible.

JOSHUA'S COMMAND TO THE SUN TO STAND STILL.

The passage in Joshua where he is supposed to have ordered the sun to stand still, apparently makes such enormous demands upon our scientific credulity that it should not be passed without a word of explanation. Close attention to the language, however, readily removes the difficulties created by an erroneous popular interpretation.

The passage (Josh. x. I2, I3) is a poetical quotation interpolated in the prose account given of a victory over the Amorites and their confederates at Bethhoron. An element which contributed to this victory was a fearful storm, in which " they were more which died with hailstones than they whom the children of Israel slew with the sword " (ver. i i). The following four verses form a parenthesis whose central portion is a quotation from the poetical book of Jasher, and is therefore naturally to be internreted with a liberality 
which that class of literature can justly claim. Moreover, the passage that makes the difficulty is fairly open to a prose translation and interpretation which create ro difficulty at all. The comand "Sun, stand thou still upon Gibeon," is rendered in the margin of our Authorized Version, "be thou silent," etc. (a well-established meaning of the word). In the case of the sun this is equivalent to "cease to shine," which would be fulfilled in its obscuration during the raging stom which followed. In the thirteenth verse the proper conclusion of the object of the prayer is that the sun should cease shining "until the people had avenged thenselves upon their enemies."

In the words of the very learned and orthodox commentator Keil,-

"Joshua can scarcely have intended by this to express the wish that God would work a miracle by his omnipotence, and make the sun and moon stand still; at the most he can only have been anxious that the sun and moon should not set till Israel had entirely defeated his enemies. And, therefore, when the poet announces in the following words the fulfillment of that desire, 'and the sun waited and the moon stood still till the people had avenged themselves upon their enemies' (ver. I3); he is only saying that God hearkened to Joshua's prayer, and gave the Israelites a complete victory over their enemies before the setting of the 
sun and moon, without intending to affirm that the sun and moon miraculously stood still."

"If we had before us simple prose or the words of the historian himself, we should without the least hesitation admit that the day was miraculously lengthened in consequence of a delay in the course and setting of the sun. But verses $\mathrm{I} 3$ and $\mathrm{I}+$ contain merely an amplification or poetical expansion of the words really uttered by Joshua in the heat of the conflict: 'Sun, wait .... till the people have avenged themselves upon their enemies'; and we should therefore entirely overlook the essential nature of poetry, if we adhered closely to the words of the poet, and so understood them to mean that the day was miraculously prolonged because the sun stood still. In fact it would betray an utter inability to enter into the spirit of poetry or of figurative writing, to continue to regard the words of Joshua, 'Sun, wait at Gibeon, and Moon, in the valley' of Ajalon,' either as a command to the sun and mon, or as a prayer that God would cause them to stand still." 11 
CHAPTER III.

\section{ISRAEL IN EGYPT.}

WiTH this brief outline of the general confirmation of the later portions of the Old Testament, we will now proceed to a more specific presentation of a mass of recently discovered scientific facts which have a distinct bearing upon the truth of a number of the more startling statements incorporated into the early part of the biblical history. We shall dwell with fullness upon these facts, not so much because they are more important than others, but because they are in the line of studies which I have been pursuing for many years, and which lead to results which are as yet but imperfectly known to the general public, but which are so distinct a contribution to the discussion that it is important to have them presented with such fullness that they shall not hereafter be neglected.

Several of the brief and fragmentary historical statements which are made in the early part of the Pentateuch involve natural phenomena which so challenge scientific investigation that they afford an unusual opportunity for cross-examination. But, as already remarked, it is important to premise that scientific facts 
can be intelligently stated in every form of literature. It is the province of the man of science to discern the substratum of fact in the statements of uncultured men. Indeed, the plain statements of such are often of highest scientific value; for, by analyzing them, it is usually not difficult to determine the so-called "personal equation," and arrive at the kernel of truth. At the same time it should be remembered that the determination of the personal equation of a witness is as important in the case of a scientific man as it is in that of an ordinary observer. The testimony of any one who simply reports the impressions made upon his senses, without going into an explanation of the phenomena which lie beyond his ken, is highly appreciated by scientific men.

It is important constantly to emphasize the fact that all statements, whether in the Bible or out of the Bible, demand interpretation. We must first determine what it is which has really been said. "The Bible is what the Bible means." In statements made with particular ends mainly in view, the implications involved must be considered in light of well-established rhetorical principles. When it is said, for example, that a biack thunder-cloud overspreads the heavens, it is petty criticism to call attention to the fact that a cloud never is perfectly black. When it is said that the zihole country is devastated by some calamity, it would be ridiculous 
to interpret that as a mathematical formula, and to challenge the truth of the statement by showing that there were certain garden spots that had escaped the devastation. So, in describing the plagues of Egypt, it is pitiable criticism to find a discrepancy in the statements which declare, in one place, that the "hail smote every herb in the field, and brake every tree of the field," while, in a following paragraph, it is threatened that the locusts "shall eat the residue of that which is escaped, which remaineth unto you from the hail, and shall eat every tree which groweth for you out of the field." And yet it would be equally erroneous to minimize these statements, and interpret them as expressing evils of small extent.

It is necessary to say so much in general, even at the risk of some repetition, in order to ward off that carping criticism of biblical history which first gives to it an interpretation out of character with the style of the literature, and then, in rejecting the interpretation, asserts that the account itself is to be rejected. We refuse to recognize the wisdom of interpreters, however learned they may be, who put upon common language the specific and finical significance of dilettante writers.

In the account of the sojourn of Israel in Egypt, we find ourselves peculiarly in the realm of historical 
reality. It is worthy of notice that the seven-year famine of Joseph's time is by no means an isolated event in Egyptian history. An inscription on an island near the First Cataract, between Assouan and Philae, dating probably from the third century B.c., describes a famine, which occurred about 3000 B.c., occasioned by successive years of low water. ${ }^{1}$ These periodical famines receive much light, and the record of them becomes more easily credible, from a study of the physical conditions which determine the growth of crops in Egypt. The more one investigates the subject, the more he is surprised at the delicacy of the balance of physical forces which annually determines the prosperity of the Egyptian agriculturist. Mr. Moses Cotsworth has published an interesting work upon the pyramids, ${ }^{2}$ to show that they represent a series of experiments to obtain a trustworthy sun-dial from whose shadow the exact dates of the vernal and autumnal equinoxes could be obtaned, and that this object was at last attained in the Great Pyramid of Cheops.

The difficulty and the importance of determining these exact points of time each year are not generally appreciated. Few realize how much we owe to the astronomical observations of the ancients in determining the precise length of the year. Since this is 365 dars, 5 hours, +8 minutes, +6 seconds, the point shifts 
so imperceptibly that long observations must hav, been required to ascertain the exact period. But is was especially necessary to determine this in Egypt, in order that the crops might be sown at a proper time. For, if the rotation of crops each year can be properly aljusted, two crops, and sometimes three, can be secured; while, if a mistake of even a few days is made in the time of sowing the first crop, the second one would be imperiled, and the third one rendered impossible. Our friend suggested that the successive years of plenty and famine were occasioned by the skill with which the right time for sowing the first crop was determined in the years of plenty, and the failure to observe the most farotable seedtime in the years of famine.

From what has been said, it can be easily seen that, when population had reached the great density which it evidently had in Egypt, where the margin between plenty and want was so narrow, a slight mistake in astronomical observations might have produced at series of disastrous years. Indeed, our friend further suggested, that he was not sure but that the years of famine were produced purposely by Joseph to secure for Pharaoh the nationalization of the land, whereby, as now under the strict justice of English rule, the distribution of water could be regulated more equitably by the central authorities. And it is evident that, where depend 
ence is had upon irrigation, success can be obtained only by the strongest form of centralized government.

But, apart from such considerations, there are certain physical elements in the problem which render a solution easy without involving human nature in such questionable operations. It was long since surmised by Sir Robert Murchison, even before the lakes of Central Africa were discovered, that the inundations of the Nile indicated that Central Africa was shaped like a great saucer, in which the accumulating waters in the rainy season rising a few feet would serve as a reservoir to secure the prolonged high-water which was necessary for the fertility of Egypt.

We now know that this is the case. The water of the rainy season accumulates rapidly in the great central lakes, but it can pass through the constricted outlet only in a limited stream, and if this outlet should be liable to obstructions, it might occur that there would be a deficiency of outflow for a series of years, followed by an unusual abundance for another series of years, and then a still greater deficiency for a following period. It has long been known that the accumulation of vegetable matter technically known as the sudd has sometimes collected in the upper part of the Nile to such an extent as to obstruct the flow of water for a period, and produce great distress in Lower Egypt. It 
is probable that this was the cause of the extreme low water and drought which existed in Egypt from the year 1064 A.D. to the year I07 I, when the whole country was well-nigh disorganized through the effects of the famine. Of this period Edward Stanley Poole gives the following vivid account:-

"The most remarkable famine was that of the reign of the Fátimee Khaleefeh, El-Mustansir billáh, which is the only instance on record of one of seven years' duration in Egypt since the time of Joseph (A.D. $106+-107 \mathrm{I})$. This famine exceeded in severity all others of modern times, and was aggravated by the anarchy which then ravaged the country. Vehement drought and pestilence (says Es-Suyootee, in his Hosn el Mohádarah, MS.) continued for seven consecutive years, so that they [the people] ate corpses, and animals that died of themselves; the cattle perished; a dog was sold for five deenárs, and a cat for three deenárs.... and an ardebb (about five bushels) of wheat for one hundred deenárs, and then it failed altogether. He adds, that all the horses of the Khaleefeh, save three, perished, and gives numerous instances of the straits to which the wretched inhabitants were driven, and of the organised bands of kidnappers who infested Cairo and caught passengers in the streets by ropes furnished with hooks and let down from the houses. This account is confirmed by El-Makreezee (in his Khitat), from whom we further learn that the family, and even the women of the Khaleefeh fled, by 
the way of Syria, on foot, to escape the peril that threatened all ranks of the population.":

Again, in A.D. I IO6, as is related by the Arabic historian Elmacin, there was a period of low water which caused great alarm in Egypt. Whereupon "the 'Sultan of Egypt' sent an envoy with magnificent presents to the Emperor of Ethiopia, begging him to remove the cause of the Nile's failure in that year, and so save Egypt from the horrors of famine. The Ethiopian monarch was ultimately persuaded 'to suffer a dam to be opened that had turned the river, which, taking its usual course, rose three cubits in one lay.' The historian records that 'the envoy on his return received great honors' from the relieved Egyptians." "4

In the year I 899 considerable alarm was caused by the deficiency of water coming down the Nile. In a letter to the Times, Mr. Willcocks, the eminent English engineer in charge of the irrigation works in ligypt, describes the cause, together with the remedy, in the following words:-

"... The White Nile is completely closed by the iudd, and the waters are wandering over the immense swamps which stretch from latitude 7 to latitude $\mathbf{~} 0$. The failure of this supply in the summer of 1900 will be serious. Now England holds the keys of the Nile. The waters which leave the Great Lakes are considered never to fall below i 8,000 cubic feet per second (see 
Sir W. Garstin's last report on the Soudan, published by the Egyptian Government). The discharge at Assouan, in spite of the additions of surface and subsoil waters from the Gazelle, the Sobat, the Blue Nile, and the Atbara, has within the last twenty-five years twice fallen as low as 7,900 cubic feet per second, and may again fall as low, or even lower. What becomes of the immense body of water which leaves the lakes? After passing Lad, the White Nile splits up into numerous branches which lose themselves in the swamps. 'Dizide et Impera.' 'The swamps vanquish the Nile. Now if a very small expedition were to find its way to Lado ria Mombasa, and engage laborers among the Bari and Madi tribes, it would be a comparatively easy task to close the heads of the Bahr Seraf and other channels which leave the right bank and confine the wa. ter to the Bahr-el-Jebel, which passes by Bor and Shambeh. (Colonel Martyr says the sudd is thirty miles north of Shambeh. If he had had a canal engineer with him, he might have cut the sudd and come on to Khartum.) (Once the waters of the Great Lakes were confined to one channel they would be able to account for any amount of sudd. No attempt has ever been made to cut the sudd with the aid of the current. This is the true way to do it, looked at from the point of view of the hydraulic engineer. Once the sudd is removed, it will be easy, with the aid of a dredger and willows, to confine the water permanently to one channel, because it is muddy for three months in the year. 
Willows will have to be imported, as none are to be found in the White Nile or the Gazelle river; and very possibly it is owing to their absence from these regions that the swamps have become so unmanageable." ${ }_{5}$

Since this letter of Mr. Willcocks's, Lord Cromer's report for the year 1900 on the "Condition of Egypt and the Soudan" gives further interesting and significant information. From this it appears that the surface of Lake Victoria Nyanza had fallen from three feet two inches in 1898 to one foot seven inches in I900, and that Major Peake was making good progress in removing the sudd by cutting it up in large blocks; but

"instead of sudd being, as had been supposed, a tangle of weeds floating on the water and descending a few feet below the surface, it proved in most cases to be a mass of decayed vegetation, papyrus roots, and earth, much resembling peat in consistency, and compressed into such solidity by the force of the current that men could walk over it everywhere, and even elephants could, in places, cross it without danger. One block in the Bahr-el-jabel, one hundred and forty miles south of Lake No, is twenty-five miles long. Another fifty-two miles south is fifty-three miles long. In both instances the true channel of the river is blocked by sudd, and it now follows a false channel; in the former instance it passes through a series of broad shallow lakes." 6 
In view of these lake reservoirs in Central Africa, and of the readiness with which their outlets may be temporarily obstructed, successive years of plenty and of famine in Egypt no longer seem a mystery. The real mystery of the Bible account connected with the events of Joseph's career is the supernatural revelation made to him, which, being itself a miracle, elevated the whole transaction into the realm of the miraculous. It is to be noted, however, that the biblical account is not compromised by any doubtful references to supernatural agency in the production either of the years of plenty or of famine. We may, therefore, easily imagine the progress of events to have been something as follows :-

The Great Lake Victoria, which forms the principal reservoir for the regulation of the flood of the Nile, has an area of forty thousand square miles, being about wice as large as Lake Huron. A gradual obstruction of the outlet which should cause its surface to rise a few feet in the course of time, would greatly enlarge its surface by flooding the marshy tracts on either side, and thus store up an immense amount of water, compared with which, that to be ponded back by the dam which the Egyptian government has built at Assouan would be a mere bagatelle. That, to be sure, raises the water at Philae sixty feet, and sets it back up the river 
to a distance of one hundred and fifty miles, but as the river is not over a quarter of a mile wide, its total surface is scarcely over forty square miles, that is, onethousandth part of the surface of the Victoria Lake. A rise of two or three feet, therefore, in the great lake would store an almost incalculable amount of water.

To produce the results described in connection with the history of Joseph, we may easily suppose that the main outlet at length became so clogged with sudd that the overflow opened up a fresh channel on one side, which, by rapidly enlarging itself, would let down an abnormal amount of water for a series of years, and so supply the conditions of successive years of plenty. At length these chamnels became again filled with sudd, thus obstructing the water and causing years of famine below, until the reservoir had again filled up with water and the channel could readjust itself in more permarent form. This succession of events is easy cnough to imagine as taking place in conformity with the foreorlained conditions existing in the region. Indeed, so natural does the succession of events recorded now seem, that it is capable of being perceived and believed upon as small amount of evidence as that which would establish the occurrence of any ordinary event. The Nile itself is a wonderful illustration of the complicated character of Divine Providence. The 
revelation of a small section of that wonder to a divinely chosen agent, such as Joseph was, in the training of the chosen people, is as easy to believe as anything else which is supernatural.

VACILLATIONS OF THE GOVERNAENT.

The favor with which the children of Israel were received in Egypt is rendered altogether credible from the fact that it was during the period of the Hyksos, or Shepherd Kings, who were themselves conquerors from the East, and had their capital, Zoan, between Egypt and Canaan. The location of Israel in Goshen is likewise a most natural thing, since it gave them both a border-land for the pasture of their flocks and a portion of the most fertile soil of the Nile Valley for their occupation. At the same time that it would strengthen the reigning dynasty to have a settlement of such shepherds in Egypt, it was good policy to have their location where they would be least likely to provoke the envy of the native Egyptians.

But the arrival of a new king who knew not Joseph points clearly to the change of dynasty by which the Hyksos were expelled from Egypt. The native dynasty which came into power, would naturally become the oppressors of Israel. The description of this oppression, given in such dramatic languare in the book of 
Exodus, is illustrated in the most lifelike manner by the recent discoveries at Pithom and Rameses.

"Exodus i. 8 Now there arose a new king over Egypt, who knew not Joseph. 9 And he said unto his people, Behold, the people of the children of Israel are more and mightier than we: Io come, let us deal wisely with them; lest they multiply, and it come to pass, that, when there falleth out any war, they also join themselves unto our enemies, and fight against us, and get them up out of the land. I I Therefore they did set over them taskmasters to afflict them with their burdens. And they built for Pharaoh store-cities, Pithom and Rameses. ... I3 And the Egyptians made the children of Israel to serve with rigor: $1+$ and they made their lives bitter with hard service, in mortar and in brick, and in all manner of service in the field, all their service wherein they made them serve with rigor."

"V. 6 And the same day Pharaoh commanded the taskmasters of the people and their officers, saying, 7 Ye shall no more give the people straw to make brick, as heretofore: let them go and gather straw for themselves. 8 And the number of the bricks, which they did make heretofore, ye shall lay upon them: ye shall not diminish aught thereof: for they are idle: therefore they cry, saying, Let us go and sacrifice to our God. 9 Let heavier work be laid upon the men, that they may labor therein; and let them not regard lying words.

"Io And the taskmasters of the people went out, 
and their officers, and they spake to the people, saying, Thus saith Pharaoh, I will not give you straw. I I Go yourselves, get you straw where ye can find it: for nought of your work shall be diminished. I 2 So the people were scattered abroad throughout all the land of Egypt to gather stubble for straw. I3 And the taskmasters were urgent, saying, Fulfill your works, your daily tasks, as when there was straw. It And the officers of the children of Israel, whom Pharaoh's taskmasters had set over them, were beaten, and demanded, Wherefore have ye rot fulfilled your task both yesterday and to-day, in making brick as heretofore?

"I5 Then the officers of the children of Israel came and cried unto Pharaoh, saying, Wherefore dealest thou thus with thy servants? I6 There is no straw given unto thy servants, and they say to us, Make brick; and, behold, thy servants are beaten; but the fault is in thy own people. I7 But he said, Ye are idle, ye are idle: therefore ye say, Let us go and sacrifice to Jehovah. I 8 Go therefore now, and work; for there shall no strav be given you, yet shall ye deliver the number of bricks. I9 And the officers of the children of Israel did see that they were in evil case, when it was said, Ye shall not diminish aught from your bricks, your daily tasks."

All this reads like a genuine excerpt from the straightforward record of an eye-witness. It is a circumstance of the $1:$ tmost historical interest that in this 
very locality the have been found storehouses, of that same age, conforming in every particular to this description. In i 883 Edouard Naville unearthed numerous such storepits at Tel el-Maskhûta, on the border of Goshen, along the line of the old Fresh-water Canal leading from the delta of the Nile to the Gulf of Suez. The place was more definitely located by inscriptions as Pi-Tum, "the abode of Tum," corresponding to Pithom, and Thuket, corresponding to Succoth, built by Rameses II. The place was further identified with Heroopolis, or Ero, of classical times; these names designating them as containing storehouses. Here Naville excavated numerous strongly built treasure-chambers, separated by brick partitions from eight to ten feet thick. The storehouses occupied almost the whole extent of Pithom, with the walls, which were six hundred and fifty feet square, and twenty-two feet thick. In the walls of the storehouses could be seen the several courses of sun-baked brick, some made with straw and some without straw. Such a newly discovered conformity between the Bible account and the conditions surrounding these cities stamps the history as genuine. The story has not been tampered with by later redactors. 
CHAPTER IV.

\section{THE EXODUS.}

WE have in the Pentateuch the records of four startling events which are peculiarly open to scientific crossexamination. They are: ( I ) the passage of the Red Sea; (2) the parting of the Jordan; (3) the destruction of Sodom and Gomorrah; and $(4)$ the Noachian deluge. These we will now test by comparing them with the physical conditions brought to light by recent investigations, enabling us to determine the extent to which the accounts have been vitiated, if at all, by the imagination of reporters or copyists. We shall attempt to show that these accounts are of such a striking character, and are so connected with the operation of profound, and until recently unknown, laws of nature, that the imagination of later times could not have been allowed to modify them without introducing incongruous and impossible elements. If it shall be found that the statements correspond to the phenomena which, according to modern scientific investigation, were hatural to the places and the occasions, we shall have the strongest possible confirmation that they are the reports of eye-witnesses which have been transmitted to us without modification. 
It is not, however, the part of science directly to prove the truth of these fragmentary bits of history; they are to be believed primarily on the evidence of the documents themselves. All that science can say concerning these events relates merely to the inherent probability of such occurrences. A scientific examination of the physical conditions involved in the statements will be of service merely in the removal of objections which may be raised by reason of our ignorance of those conditions. If it can be shown that these statements of startling facts do not make extravagant demands upon our beliefs concerning the uniformity of the course of nature, but that they are in close analogy with the operation of her widely known laws, we shall have gained a great point in establishing the credibility of the narratives.

Just here a word more should be said about the miraculous character of these events; and, to do this, it will be necessary to get clearly before our minds what a miracle really is, and what are its relations to the course of nature.

The best definition of nature is that which conceives of it simply as the system of causally connected sequences of the universe. Thus conceived, the free wills both of man and of the Creator are forces outside of nature having the mysterious power of piercing the 
joints of this harness of causally connected sequences, and modifying the results according to an intelligent purpose. Man by his volition brings about new and unexplainable combinations of natural forces. To a limited extent he changes the face of nature. He forms combinations that are new, and produces results which are extranatural. Nature herself would never produce a house, or build a railroad, or develop domestic plants and animals. ${ }^{1}$

There is no more philosophical difficulty in conceiving of God's working a miracle than there is in conceiving of man as producing an extranatural effect through his control and combinations of natural forces. The difference between a miracle and the accomplishment of man's free will lies chiefly in the magnitude of the events and the extent of the control which is manifested. Man is limited in his control of nature. He can leap a few feet into the air. But even this is not a natural exhibition of power. Mere natural forces would forever hold him to the ground. It is through an extranatural combination of forces that man's will instigates and secures this result. But, however much he may will it, he has not the power, in the present order of things, to leap into the air more than a few feet. He has not such control of forces that he could leap to the moon, even with the help of an air-ship. 
With God, however, there is no such limitation of power. He has power to bring about results which are superhuman as well as supernatural. And while we may not know the exact limit of man's power, so as strictly to define the sphere of the superhuman, and determine the boundary beyond which the modifications of nature would necessitate divine control, and so be strictly called miraculous, we have no practical difficulty in setting off by themselves the most of the facts which are miraculous.

We have no hesitation in specifying as miraculous such facts, for example, as the ascension and the resurrection of Christ, the raising of Lazarus, the multiplication of the loaves and fishes, the stilling of the tempest upon the sea, and the changing of the water into wine. Nor should we question in the Old Testament the strictly miraculous character of the preservation of Shadrach, Meshach, and Abed-nego in the fiery furnace, of the translation of Elijah, of the descent of the fire upon Mount Carmel to burn the sacrifices which had been laid upon the altar, and of many other instances which it is not necessary to name. In all these the facts may have been accomplished through the action of the Divine Will in making new combinations of the causally connected sequences which we have given as the definition of nature. Still, we have no 
ciue, and probably can never have any clue, to the channels through which the Divine Will has operated.

But the class of facts which we now proceed to consider belongs to what have been called "mediate miracles." In these we are permitted to see the forces which have been used, and to judge of them by analogy, comparing them with things with which we are more or less familiar.

\section{PASSAGE OF THE RED SEA.}

One of the best opportunities for thus testing the truthfulness of an extraordinary historical statement is found in the account of the crossing of the Red Sea by the children of Israel. The story is remarkable in every respect, and not the least in the way it puts forth the secondary causes through which the way was opened for the deliverance of the people. In a literature written for religious purposes, in which it was both natural and proper to throw into the foreground the direct agency of God, it is surprising that so much emphasis is laid upon the means employed by the Creator. It was indeed the Lord who "caused the sea to go back." But he did it "by a strong east wind, which blew all night," and "made the sea dry land." And again, in the song which recounts the event, it vas by the "blast of his nostrils" that the waters were 
piled up. And when the waters came back to overwhelm the Egyptians it was God who " did blow with his wind that the sea should cover them."

The whole exquisite passage is as follows:-

"Exodus xii. 37 And the children of Israel journeyed from Rameses to Succoth, about six hundred thousand on foot that were men, besides children. 38 And a mixed multitude went up also with them; and flocks, and herds, even very much cattle. . . xiii. 20 And they took their journey from Succoth, and encamped in Etham, in the edge of the wilderness. . . . xiv. I And Jehovah spake unto Moses, saying, 2 Speak unto the children of Israel, that they turn back and encamp before Pi-hahiroth, between Migdol and the sea, before Baal-zephon: over against it shall ye encamp by the sea. 3 And Pharach will say of the children of Israel, They are entangled in the land, the wilderness hath shut them in. 4 And I will harden Pharaoh's heart, and he shall follow after them; and I will get me honor upon Pharaoh, and upon all his host; and the Egyptians shall know that I am Jehovah. And they did so. 5 And it was told the king of Egypt that the people were fled: and the heart of Pharaoh and of his servants was changed towards the people, and they said, What is this we have done, that we have let Israel go from serving us? 6 And he made ready his chariot, and took his people with him: 7 and he took six hundred chosen chariots, and all the chariots of Egypt, and captairs over all of them. 8 And Ieho- 
vah hardened the heart of Pharaoh king of Egypt, and he pursued after the children of Israel: for the children of Israel went out with a high hand. 9 And the Egyptians pursued after them, all the horses and chariots of Pharaoh, and his horsemen, and his army, and overtook them encamping by the sea, beside Pi-hahiroth, bofore Baal-zephon.

"Io And when Pharaoh drew nigh, the children of firsil lifted up their eyes, and, behold, the Egyptians ware maction arer ticen; and they were sore afraid: and the children of Israel cried out unto Jehovah. . . . 13 And Moses said unto the people, Fear ye not, stand still, and see the salvation of Jehovah, which he will work for you to-day: for the Egyptians whom ye have seen to-day, ye shall see them again no more tor ever. It Jehovah will fight for you, and ye shail hold your peace.

"I5 And Jehorah said unto Moses, Wherefore criest thou unto me? Speak unto the children of Israel, that they go forward. 16 And lift thou up thy rod, and stretch out thy hand over the sea, and divide it: and the children of Israel shall go into the midst of the sea on dry ground. . . .

" 2 I And Moses stretched out his hand over the sea; and Jehovah caused the sea to go back by a strong east wind all the night, and made the sea dry land, and the waters were divided. 22 And the children of Israel went into the midst of the sea upon the dry ground: and the waters were a wall unto them on their 
right hand, and on their left. 23 And the Egyptians pursued, and went in after them into the midst of the sea, all Pharaoh's horses, his chariots, and his horse. men. 24 And it came to pass in the morning watch. that Jehovah looked forth upon the host of the Egyptians through the pillar of fire and of cloud, and discomfited the host of the Egyptians. 25 And he took off their chariot wheels, and they drove them heavily; so that the Egyptians said, Let us flee from the face of Israel; for Jehovah fighteth for them against the Egyptians.

" 26 And Jehovah said unto Moses, Stretch out thy hand over the sea, that the waters may come again upon the Egyptians, upon their chariots, and upon their horsemen. 27 And Moses stretched forth his hand over the sea, and the sea returned to its strength when the morning appeared; and the Egyptians fled against it; and Jehovah overthrew the Egyptians in the midst of the sea. 28 And the waters returned, and covered the chariots. and the horsemen, even all the host of Pharaoh that went in after them into the sea; there remained not so much as one of them. 29 But the children of Israel walked upon dry land in the midst of the sea; and the waters were a wall unto them on their right hand, and on their left. 30 Thus Jehovah saved Israel that day out of the hand of the Egyptians; and Israel saw the Egyptians dead upon the seashore. 31 And Israel saw the great work which Jehovah did upon the Egyptians, and the people feared Jehovah; and they believed in Jehovah, and in his servant Moses. 
"XV. I Thin sans Moses and the children of Israe1 this song unto Jehovah, and spake, saying,

"I will sing unto jehovah, for he hath triumphed gloriously:

The horse and his rider hath he thrown into the sea.

2 Jehovah is my stre igth and song, And he is become ny salvation:

This is my God, and I will praise him;

My father's $\left.\mathrm{G}^{\prime}\right)$, and I will exalt him.

3 Jehovah is a man of war:

Jehovah is tis name.

4 Pharaoh's crariots and his host hath he cast into the sid;

And ni, cnosen captains are sunk in the Red Sea.

5 The rierps cover them:

Thry went down into the depths like a stone.

6 Thy right hand, O Jehovah, is glorious in power,

'I hy right hand, O Jehovah, dasheth in pieces the enemy.

7 And in the greatness of thine excellency, thou overthrowest them that rise up against thee :

Thou sendest forth thy wrath, it consumeth them as stubble.

8 And with the blast of thy nostrils the waters were piled up.

The floods stood upright as a heap

The desps were congealed in the heart of the sea.

9 The encmy said, 
I will pursue, I will overtake, I will divide the spoil ;

My desire shall be satisfied upon them;

I will draw my sword, my hand shall destroy them ;

10 Thou didst blow with thy wind, the sea covered them:

They sank as lead in the mighty waters.

I I Who is like unto thee, O Jehovah, among the gods?

Who is like thee, glorious in holiness,

Fearful in praises, doing wonders?

$\therefore$ a Thou stretchest out thy right hand,

The earth swallowed them.

13 Thou in thy loving kindness hath led the people that thou hast redeemed:

Thou hast guided them in thy strength to thy holy habitation.

If The peoples have heard, they tremble:

Pangs have taken hold on the inhabitants of Philistia.

I: Then were the chiefs of Edom dismaye?

The mighty men of Moab, trembling taketh hold upon them:

All the inhabitants of Canaan are melted away.

$\therefore$ Teror and dread falleth upon them;

By the greatness of thine arm they are as still as a stone;

Til thy people pass over, () Jehovah.

Till thy people pass over that thou hast purchased. 
17 Thou wilt bring them in, and plant them in the mountain of thine inheritance,

The place, O Jehovah, which thou hast made for thee to dwell in,

The sanctuary, $O$ Lord, which thy hands lave established.

I 8 Jehovah shall reign forever and ever.

" 19 For the horses of Pharaoh went in with his chariots and with his horsemen into the sea, and Jehovah brought back the waters of the sea upon them; but the children of Israel walked on dry land in the midst of the sea. 20 And Miriam the prophetess, the sister of Aaron, took a timbrel in her hand, and all the women went out after her with timbrels and with dances. 21 And Miriam answered them,

"Sing ye to Jehovah, for he hath triumphed gloriously ;

The horse and his rider hath he thrown into the sea."

In much of the popular comment upon this account of the sacred writer, intervention of secondary agencies has not been properly noticed. But, clearly, we are not at liberty to interpret it without giving due weight to the repeated mention of the secondary causes said to be employed by the Creator in the production of the phenomena. The Lord opened the sea before the children of Israel, but he used the wind as his instrument. This is expressiy and repeatedly said. But, on the 
principle that whatever a person does through an instrument he does himself, this work is none the less the Lord's than if he had done it directly, without any intervening secondary cause. Such reference to the secondary agency by which the event was brought about invites us to an examination of the physical conditions in which such a cause would produce the given result. In the plainest manner, therefore, it opens itself up to scientific inquiry.

Physical Conditions North of Suez.-The Gulf of Suez ends in a narrow point of shallow water, extending a few miles nortl of the city. The junction of this inlet with the main gulf is partially obstructed by a narrow bar, which is almost out of the water at certain stages of what may be called the tide,-though it is not a real tide which affects the depth of the water, but, as is now well known, the wind. It was the surmise of Dr. Edward Robinson, who has been followed by many others, that the place of the crossing was at Suez, and that this bar was the bridge by which it was effected at low water. But the bar is so narrow that it would be more of a miracle to get the host of Israel across in the time allotted than it would be to disperse the waters which submerge it.

More careful study of the situation, and the increasing light shed upon it by geological investigations, have 
tended to shift the scene a few miles farther northward, where conditions are found which comport equally well with the position into which the Israelites were brought by their three-days' march, and at the same time reveal other conditions perfectly fitted to account for the whole transaction.

The shallow inlet projecting northward from Suez really occupies the lower part of a narrow depression, or we may call it channel (several miles of which are now dry), extending through to the Bitter Lakes, and thence on up to Lake Timsah, on which is the present city of Ismailia, which probably occupies the site of the Etham of biblical times. The Suez Canal has taken advantage of this prolonged depression, and been able, by a shallow open cut through rock, which is at the highest point (near Chaloof) twenty-seven feet above sea-level, to connect the Gulf of Suez with the largest of the Bitter Lakes. Following this lake to its northern end, another cut through land, which is at Serapeum thirty feet above sea-level, brings it to Ismailia, upon the northern end of Lake Timsah. Just north of this point occurs the deepest cut for the canal through a land surface, which is from seventy to eighty feet above sea-level, and has been the passageway between Africa and Asia used by caravans and armies for thousands of years. Soon after leaving this last cut, the canal 


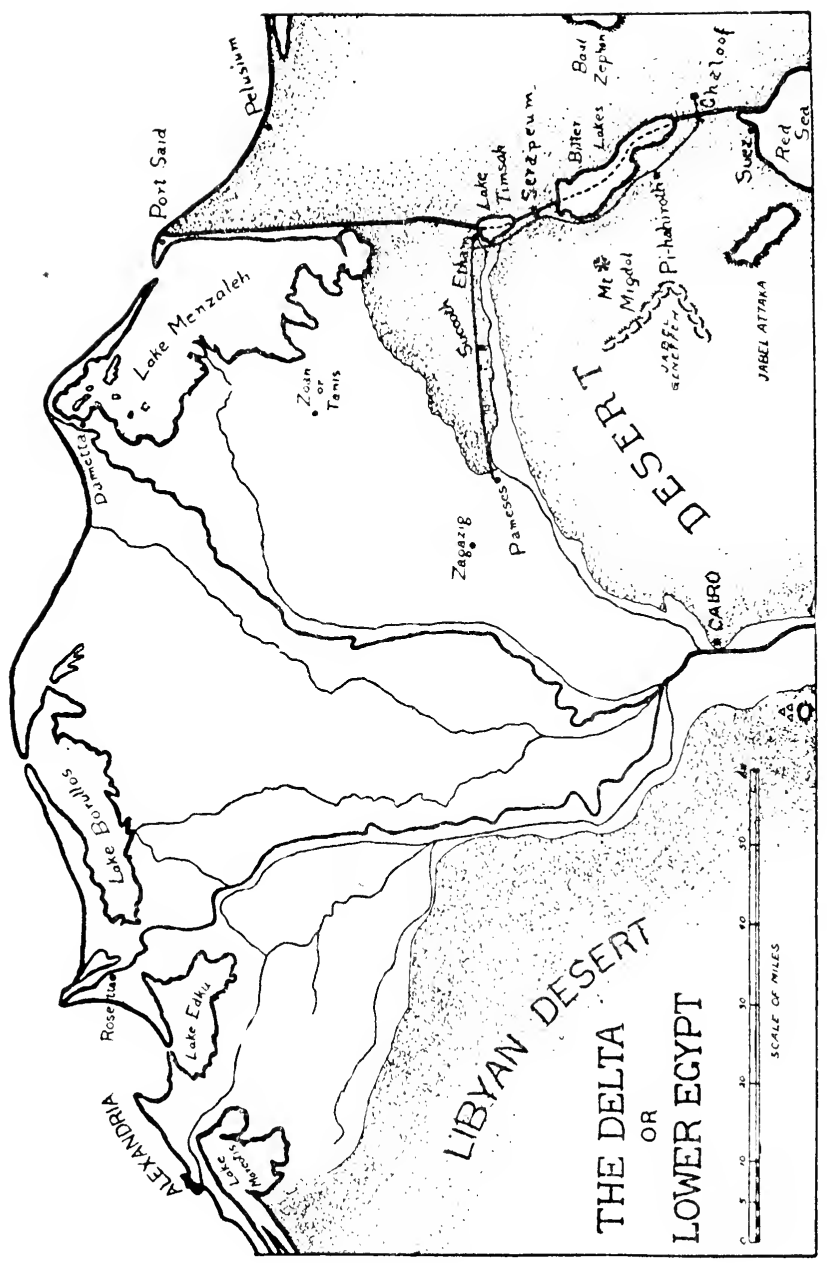


reaches the shallows of Lake Menzaleh, which stretch on the east to Pelusium, and a little beyond merge into the famous Serbonian Bog.

It thus appears that a subsidence of the land to the extent of a little more than thirty feet would cause the water of the Gulf of Suez to extend to Ismailia, and still leave the old land passage between Asia and Africa forty or fifty feet above sea-level, and would cover the highest places at Serapeum and Chaloof to a depth of only a few feet.

That there was such a depression in receint times is clear from both direct and indirect evidence. During the present geological epoch the whole region around the eastern end of the Mediterrancan Sca has risen about two hundred and fifty feet. Indubitable evidence of this may be seen near the summit of the isolated croded cliff known to the Arabs as Het el-Orai, or the Crow's Nest, about half a mile south of the pyramids at Gizeh, which is about the same level with the pyramil plateau, approximately two hundred feet above the sea. Here there is a clearly defined recent sca-beach, composed of well-worn pebbles, from an inch or two to a foot in diameter, the interstices of which are filled with small oyster-shells, loosely cemented together. A collection which the writer personally made of these shells, submitted to Dr. F. L. Kitchin, 


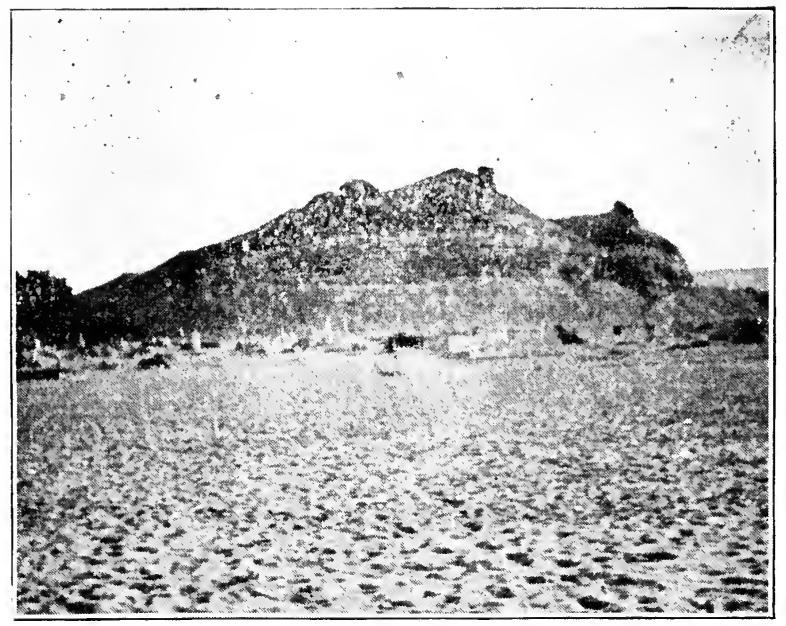

General View of the Crow's Nest, from the Pyramids.

if the British Geological Survey, were pronounced to se indistinguishable from Alectryonia cucullata, Born, a variable form which occurs in Pliocene deposits and also lives at the present day in the Red Sea. This seabeach was first discovered by Dr. Oscar Fraas, and has been described by Schweinfurth and Dawson. These observers noticed, also, that the face of the plateau had been pierced by lithodomus mollusks (Pholades rugosa. Broc.) and reported shells of Ostrea undata, Goldf., and Pecten Dunkri, May.

Another locality where similar evidence occurs is at the base of the Mokattam Hills, upon the opposite side 


\section{The Exodus.}

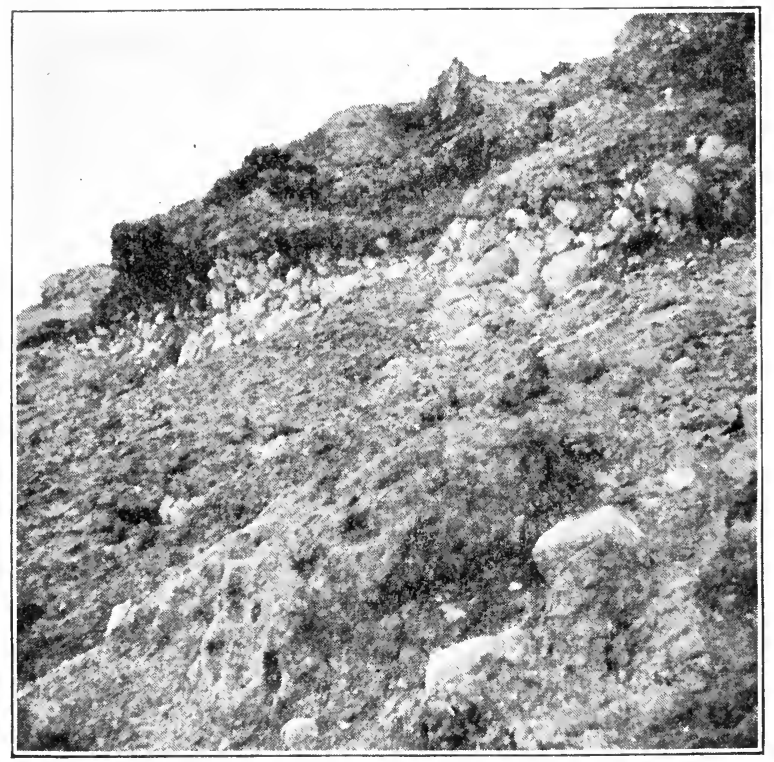

Near View of the Raised Beach on the Crow's Nest.

of the Nile from the pyramids. Concerning this, Professor Edward Hull, in his "Memoir on the Geology and Geography of Arabia Petriea, Palestine, and Adjoining Districts," says :-

"It was first recognized by Fraas, and more recently examined by Schweinfurth, who pointed out the traces of the ancient shore-line to the author on the occasion of our visit to Cairo in November, 1883. On ascending the Mokattam Hills towards Gebel el Ahmar, we 
pass over a tract of undulating ground, and reach the line of the railway from Abbasieh, and here it is said that our observations commence. We discover, from certain openings, that the ground is formed of beds of purple and yellow sand and fine gravel, a little marl and clay, with specimens and fragments of Tercbratula (T. forscata), Ostrea (O. cucullata, Born), Pecten, and Balanus-shells or species of which do not occur in the Eocene limestone formation. On crossing the railway and ascending towards the limestone cliffs, we observe that the rock is penetrated by numerous borings of Teredo, though the shell is seldom left in the perforation. We are here evidently standing on the ancient sea-margin, and at an elevation of two hundred and twenty feet above the Mediterranean and Red Seas. The presence of the beach has been detected in other places along the hills by Dr. Schweinfurth, and the Teredo borings have also been observed by him in the limestone platform on which is built the Mosque of Mehemet Ali" (p. 7I).2

Near Jaffa there is another typical deposit of the same period, described by Hull as follows:-

"The raised sea-bed stretches far inland from Jaffa, and is noticed by Lartet. It may be traced along the Jerusalem road to beyond Ramleh and Lydda (Ludd). At Jaffa the shelly sands rest on the more ancient sandstone which forms the foundation of the city, and supplies the copious springs of water necessary for the irrigation of the extensive orange and lemon groves 
which are so justly celebrated for their abundant and excellent quality; but farther inland about Ramleh, this fine sand and gravel gives place to beds of calcareous conglomerate, formed of limestone pebbles of all size, and well water-worn. This is undoubtedly an ancient sea-beach, which appears to rise to a level of considerably over two hundred feet, formed at a time when the waters of the sea extended over twelve miles beyond their present limits. In these beds M. Lartet has noticed the following species: Pectunculus riolascens, Lamk.; Purpura hemastoma, Lamk., Murex brandaris, Linn., Columbella rustica, Lamk., etc. By far the most abundant shell is that first named, and it is still the most abundant on the adjoining Mediterranean shore" (pp. 74-75).

Still another locality where the evidence is beyond question is at Lattakia, about thirty miles north of Beirut. According to the description of Rev. George Post, M.D., Professor in the American College at Beirut, Syria,-

"Beds of sea-shells and corals now living in the Mediterranean occur at elevations chiefly between one hundred and fifty and two hundred and fifty feet above the sea; but they are also found more sparingly at even higher levels. The principal locality where these shells have been observed is in a valley near the village of Qutrûjeh, in a mass of unsolidified clay, which is extremely full both of shells and corals." 


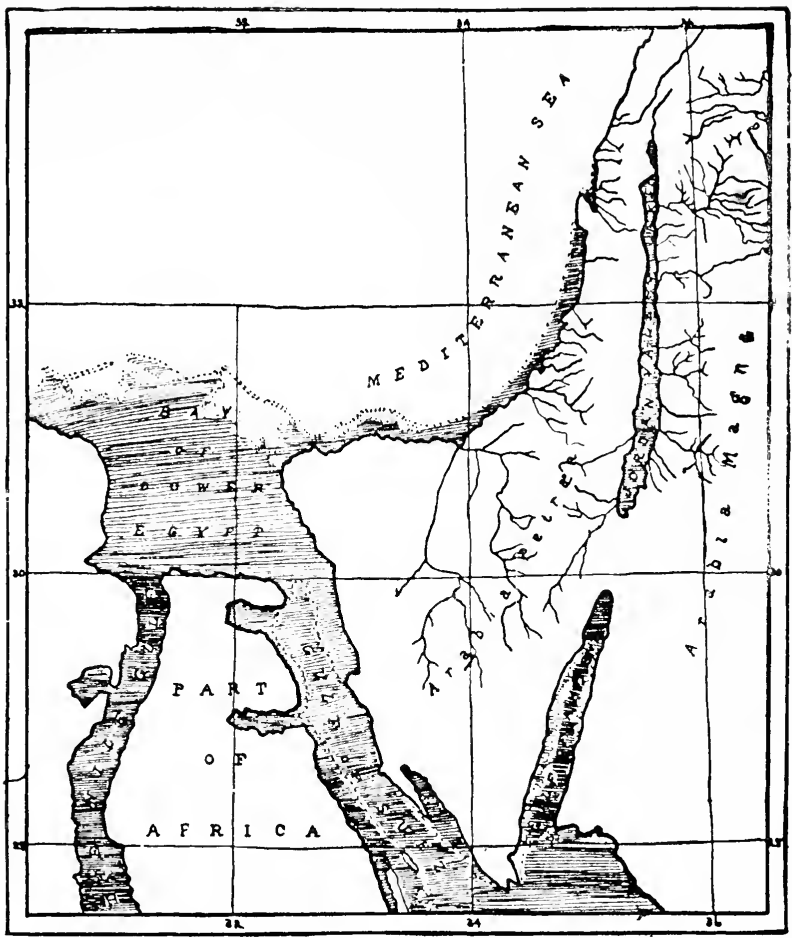

Map showing, in the shaded portion, the effect in Lower Egypt of a continental depression of 300 feet. The enlargement of the Dead Sea was an indirect result. See pages 313 and 3 I 4 .

Similar accumulations of recent shells are, according to Hull, found upon the island of Cyprus, on

" the broad terrace which stretches along Larnika Bay, bounded inland by a line of white limestone cliffs. 
This terrace is also an old sea-bed, and the cliffs formed the coast-line which was washed by the waves at a time when the land was submerged. These raised seabeds have been described by Mr. R. Russell, who recognizes in them shells of species now living in the adjoining waters of the Mediterranean" (p. 76).

Thus, as Professor Hull remarks,-

"it will be seen that all along the coast of the Levant, from Egypt, by Palestine, Syria, and extending to the Island of Cyprus, there are indications that at a period, so recent that the shells and corals are still living, the land has been submerged to a depth of from two hundred and twenty to two hundred and fifty feet. During this period Africa was an island, and the waters of the Mediterranean stretched southwards into the Red Sea" (p. 76).

Evidence of this depression is also seen in the fact that the isthmus between Suez and the Bitter Lakes is covered with recent deposits of Nile mud, holding modern Red-Sea shells, showing that, at no very distant date, there was an overflow of the Nile through an eastern branch into this slightly depressed level. The line of this branch of the Nile overflow was in early times used for a canal, which has recently been reopened to furnish fresh water to Suez, and the depression is followed by the railroad. ${ }^{*}$

- It is now more than three thousand years since the 
date of the Exodus; so that the results required for the explanation of our problem would be produced by a

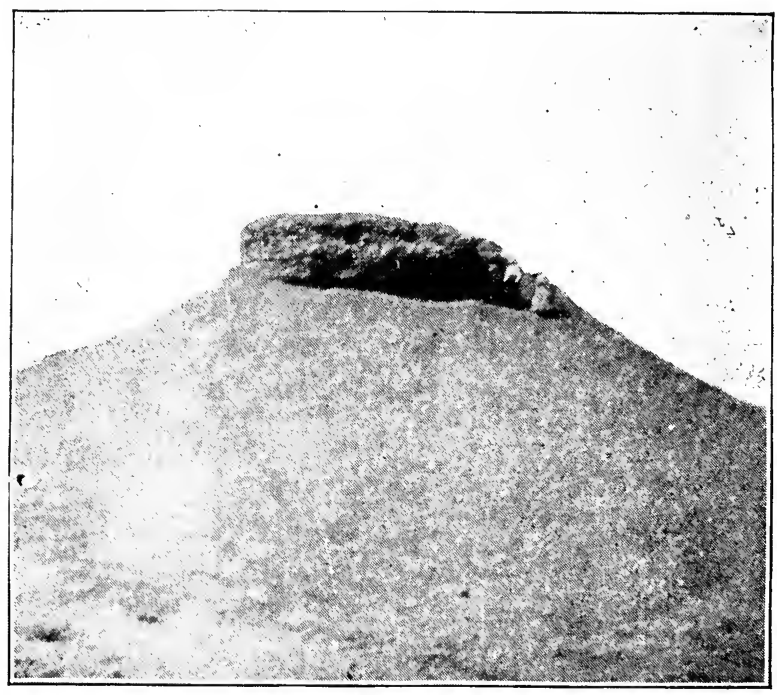

Conglomerate Knob in Desert North of Suez.

This characteristic knob, left by ancient erosion of the plain in front of Jebel Geneffeh, is only about 200 feet above the plain. It was impossible to get photographs of Jebel Geneffeh which would be worthy of reproduction. This one was taken from the plain where we supposed the children of Israel encamped (see photograph on page 109), looking northwestward, in which direction the precipitous front of Jebel Geneffeh, with Migdol between it and the Bitter Lakes, both rising from $I, 000$ to $I, 500$ feet above the sea, were in the background, while to the southwest Jebe, Attaka closed in the view in เhat direction. 
rate of change in level with which geologists are perfectly familiar. Indeed, the best-informed members of our United States Geological Survey maintain that the changes of level about our Great Lakes of North America are such that in three thousand years a part of the water which is now pouring over Niagara will be diverted, by a natural flow, into the Mississippi Valley. ${ }^{5}$ To the geologist, therefore, the supposition which we are making is of the most commonplace and reasonable order. It is such a supposition as geologists are constantly and confidently making for the solution of the most insignificant problems which are presented to them. How much more is it legitimate to use it in explanation of historical statements so strongly credited as are these in the book of Exodus!

Now, the supposed depression of thirty or thirtyfive feet, existing, three thousand years ago, over the eastern border of the Mediterranean Sea, would cause the water of the Red Sea to extend northward through the narrow valley which, from the point of view of physical geography, is a continuation of the Gulf of Suez; so that there would be a continuous line of unfordable water as far north as Etham. But, for a distance of ten or twelve miles between Suez and the Bitter Lakes, the average depth of the water would be about five feet, a depth which could be easily reduced 
to nothing by the strong east wind spoken of in the biblical account.

Effect of Wind upon Water-Lezels.-The facts about the effect of wind upon water-levels have always been more or less known, but recent observations place them now in a clearer light than they have ever been seen before." Among the most conclusive and satisfactory sets of observations upon this point are those which have been made by the officers of the United States Coast Survey upon the effect of wind upon water-levels in Lake Erie. This lake is about two hundred and fifty miles long, and its axis, running nearly northeast by southwest, is in line with that of the prevailing storms of the region. Now, it repeatedly occurs that a strong wind from the southwest lowers the water at Toledo, Ohio, which lies at the western end of the lake, to the extent of seven or eight feet, while it piles it up to the same extent at Buffalo. New York, which lies at the eastern end. A shifting of the wind from southwest to northeast produces the opposite effect, lowering the water at Buffalo and piling it up at Toledo, thus making, oftentimes within a short period, a difference of between fourteen and fifteen feet in the depth of the water of these twc ports.

Major-General Tulloch,' of the British army, re- 
ported that while assigned to duty on the Isthmus of Suez he witnessed the driving-off of the water from the eastern end of Lake Menzaleh by the wind to such an extent as to lower the level six feet. According to the map of the Suez Canal Company, the difference between the highest and the lowest water-level at Suez is ten feet and seven inches, which, since there is no tide in the Red Sea, must be due to the effect of the winds.

It would take far less than a tornado to lower the water at the northern end of the Red Sea sufficientiy to lay bare the shallow channel which we have supposed to have connected the Gulf of Suez with the Bitter Lakes, permitting any number of an organized host to cross to the other side. The advantage of this theory respecting the place of crossing, over that of Dr. Robinson, is that the gap is here so broad that the numbers mentioned in Exodus could be easily taken across in a few hours, since the distance would be no more than two or three miles, and the channel could be crossed anywhere along a line ten miles in length. ${ }^{\mathrm{s}}$

Turning again to the biblical account, we find that everything readily fits into this situation. At that time. the court of the Pharaohs was held at Zoan, about thirty miles northwest of Etham, and about the same distance northeast of Rameses, the point from which the 
children of Israel set out upon their eventful journey. As their course from Rameses was eastward along the line of the Fresh-water Canal, and their first campingplace, Succoth, a distance of from ten to fifteen miles, their next camping-place was Etham, which, as already remarked, was probably near the present Ismailia, at the head of what was then the northern projection of the Gulf of Suez.

The Place of the Crossing.- So far they had not got beyond the reach of a flank movement by Pharaoh's army, that might cut across the desert and readily intercept them on the main road to Palestine. But at this point there was a most remarkable and apparently foolish and suicidal diversion of the Israelites from their onward course. Leaving the regular road to the Promised Land, they were, by divine direction, turned southward, and reached a camp which is described as " before Pi-hahiroth, between Migdol and the sea, before Baalzephon." The exact locality of this camp cannot be determined, but every condition suits the description a little over a day's march south of Ismailia, on the west side of the Bitter Lakes. Here there is a mountain prominence, admirably conforming to the signification of the word "Migdol," upon the west, which separates a narrow, level margin along the Bitter Lakes from the wilderness, which stretches westward to 


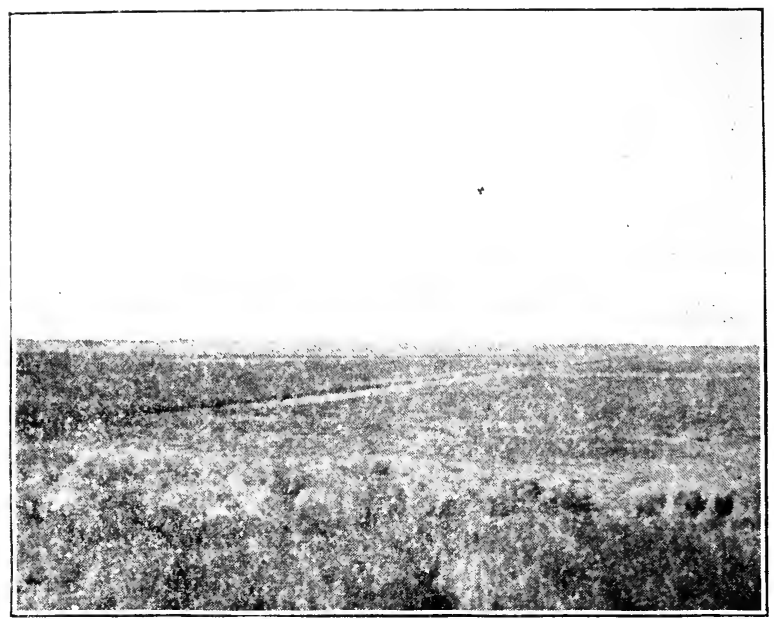

View of Jebel Attaka, from the Vicinity of Pi-hahiroth.

This view shows the plain on which the children of Israel ubably encamped the day previous to the crossing at Chaloof. (See map on page 96.) The vegetation in the immediate foreground springs up from the vicinity of the Freshwater Canal, which is immediately in the rear. This plain is covered with sand and gravel utterly devoid of vegetation, but showing marks of floods, produced by occasional cloudbursts, which have gradually washed the material down the gentle slope from the mountains in the background to the axis of depression occupied by the canal. In the vicinity of this axis of depression recent shells are found, while they are reported upon the flanks of Jebel Attaka up to an elevation of 200 or 300 feet. From this point one has an excellent view of a picturesque mountain range upon the east, the northern portion of which may well correspond to Baal-zephon. 
Cairo. There is also a mountain clearly visible east of the lakes which may well mark the site of Baal-zephon. So clear is the atmosphere, and so short are the distances, in that region, that one traveling along the line of the railroad from Rameses to Etham can distinctly see both this tower-like projection of Jebel Geneffeh, about fifteen miles away, and the peak of Jebel Attaka, rising to a height of several thousand feet, just back of Suez, fifteen or twenty miles farther. No description could better fit the conditions than that which is put, by the sacred writer, into the mouth of Pharaoh: "They are entangled in the land, the wilderness hath shut them in." From a military point of view, nc move could have been more foolhardy than that of the children of Israel in marching southward between the perpendicular face of the monoclinal ridge of Jebei Geneffeh, on the west, and the projecting arm of the Red Sea, upon the east. From such a pocket, escape could be nothing less than miraculous. There was only this advantage, that they were temporarily protected from attack upon either flank, while their rear guard was compelled to defend only a narrow field.

The judgment of Pharaoh that the children of Israel were entangled in the land, that the wilderness had shut them in, strongly supports our theory that at that time the Gulf of Suez extended up to the Bitter Lakes; 
for, how else could it have shut them in, except that there was water to the east of them a single day's journey from Etham?

Sir J. W. Dawson and others would place the fourth encampment of the children of Israel some distance north of the present southerly extension of the larger of the Bitter Lakes. But this is by no means necessary, and does not fit the situation so well as does the locality a few miles farther south, opposite what is now the dry portion of the old arm of the gulf, which was, as we have supposed, then covered with shallow water. In making this supposition, no violence is done to the text of scripture or to the necessities of the case. A vast army like the hosts of Israel at that time cannot encamp in one particular point, but are necessarily spread over a considerable territory. And we are not shut off from supposing that, in the adjustment of their camp, they had time to move to the more commodious and open plain that lies about half way between the Bitter Lakes and Suez.

We are bound to state, however, that Naville, Ebers, P'oole, De Lesseps, and some others, while in general favoring the views here presented, would place the crossing at Serapeum, between the great Bitter Lake and Lake Timsah. And it must be confessed that nearly all the arguments in favor of Chaloof would apply to 
that locality. But the distance from Etham and the position of Mount Geneffeh favor Chaloof. The man arguments of this chapter, however, would anply to cither locality.

Supposing the children of Israel to be in this position. with Jebel Geneffeh on the west. Jebel Attaka and the Gulf of Suez on the south, the shallow projecting arm of Suez separating them from the wilderness, on the east, and pressed, on the rear, by the advance guard of Pharaoh's army, the situation would seem to be desperate. It was not within the reach of the human mind, at that time, nor would it be at the present time, to calculate upon the deliverance which came. Not only were the forces of nature which were cmployed to effect it beyond the power of human control, but their action was beyond reach of human forecight. It was, however. revealed to Moses that the waters should recede, and a way of escape be opened; and we are told that "Jeho. wah caused the sea to go back by a strong east wind all the night, and made the sea dry land, and the waters were divided."

We have already given in detail the effect of a strong wind in lowering the level of the narrow body of water over which it blows. No situation better adapted for the full effect of winds, in producing a change of water-level, could be imagined than was 
found here. Even should we feel compelled to interpret strictly the word "east," the contour of the shore is such that the resultant of the forces would be to move the whole body of water from the head of the gulf into the broader and deeper portions to the south, thus laying bare a broad isthmus over which an immense organized host could pass in a few hours' marching.

A Mediate Miracle.-In analyzing the miracle, we need not trouble ourselves with the task of determining the exact point at which the immediate agency If God enters into the chain of natural causes to direct neir action to the accomplishment of this specific purpose. Some would prefer to think of this physical phenomenon as foreordained from eternity, the causes which would lead to it having been incorporated into the original creation. But even then we cannot regard as accidental the conjunction of this foreordained effect with the operations of the children of Israel on this particular day. It was by divine forethought that the line of march of the children of Israel led them to this point at that particular time, and that Moses was able to inspire them with confidence to take up their march when he should stretch out his rod over the retiring waters. Such a conjunction of the action of vast physical forces coming to the relief of a people in their dire necessity has in it all the marks of design wh:ch the 
human mind needs to connect the event dir. stly with the will of God.

But we are not shut up to this single explanation of God's relation to the event. The men of science have no formula by which they can eliminate God from direct activity in so controlling the forces of nature as to bring about new combinations and new results, as the exigencies of history and the action of man's free will may require. It is as easy for God, and no more inconsistent with what we know of the laws of nature, that he should start a storm which should be farreaching in its influence, as that a man should blow with a bellows to dust his mantel or kindle his fire. Science has no final word for the question which here meets us. This strong east wind may have been as directly aroused for this occasion as is the puff of our own breath with which we warm our fingers or cool our porridge. In both cases the action of the powers of nature is modified and diverted to the accomplishment of specific purposes which nature alone would not have accomplished.

Interpretation of the Rhetorical Language.-We cannot leave this subject, however, without alluding to some objections which may be obviated by attention to correct principles of interpretation. It is said (Ex. xiv. 22 ) that the "waters were a wall unto them on their 
right and on their left." But when we consider the natural rhetorical use of this word "wall," it presents no difficulty. In Prov. xviii. I I we are told that "the rich man's wealth is his strong city, and as a high wall in his own imagination"; while in Isa. xxvi. I we are told that "God will appoint salvation for walls and bulwarks"; and, again, in Nahum iii. 8, Egypt is described as she "that was situate among the rivers [margin, "canals"], that had the waters round about her; whose rampart was the sea [margin, "the Nile"] and her wall was of the sea." In all these cases one readily perceives that the purpose of defense which a wall serves, is the idea which is figuratively expressed. And so we find sufficient warrant for this meaning in the protection which was given by the deep water of the Bitter Lakes on one flank of the host, and that of the Gulf of Suez upon the other, as they were marching to a place of safety upon the other side. There was no chance for Pharaoh to intercept them by a flank movement. He could only press upon their rear, as he did, and come into the channel, when the returning waters overwhelmed his army.

Similarly the passages in the Song of Moses, which follows, are to be interpreted in accordance with the highly rhetorical character of the composition. There we are told that the retirement of the sea was accom- 
plished by the "blast of God's nostrils," which even a child could understand as a poetical expression for "wind." It is further said that the " deeps were congealed in the heart of the sea," which literally would imply that the children crossed on ice, but which reveals its meaning without any difficulty even to the ordinary reader. Again, in Ex. xv. I2, it is said that the eartil swallowed Pharaoh's host, where again the misunderstanding of the poetic figure, by overemphasis upon the letter, would indicate almost absolute lack of knowledge of the true principles of literary interpretation.

In conclusion, it is proper to call renewed attention to the extent to which this analysis of the biblical statements and of the physical conditions in which the history is located, confirms the account. The story fits the circumstances so perfectly, or, in other words, the conditions implied so correspond with the facts stated, that the history is supported by the strongest form of circumstantial evidence. It is not within the power of man to invent a story so perfectly in accordance with the vast and complicated conditions involved. The argument is as strong as that for human design when a key is found to fit a Yale lock. This is not a general account which would fit into a variety of circumstances. 
There is only one place in all the world, and one set of conditions in all history, which would meet the requirements. This is scientific proof. No higher proof can be found in the inductive sciences. The story is true. It has not been remodeled by the imagination either of the original writers or of the transcribers. It is not the product of mythological fancy or of legendary sccretion. 
I1 8 Physical Preparation for Israel in Palestine.

CHAPTER V.

\section{PHYSICAL PREPARATION FOR ISRAEL IN PALESTINE.}

AT the risk of some repetition, we would again cal? attention to the fact, that, however we may emphasize the direct agency of God in answering prayer, and in providing for the wants of nations in the great crises of history, we are not at liberty to overlook the prevenient care for men which appears in the whole order of nature. Indeed, it is often difficult tc distinguish between the direct and the indirect agencies through which the Creator provides for human want. When, however, the element of time is dropped out of our thought, the paternal love which intelligently lays in store the provisions which the children will need when they arrive at maturity seems as real a manifestation of interest as are the supplies which are brought into the household from day to day.

As already remarked, the only tenable view of the universe is that of an organized system of secondary causes working towards definite ends which are more or less distant, but which, at innumerable points, are open to limited modification and control by the human will, and, at every point, to control by the divine will. 
In such a conception of nature, it is neither necessary nor proper to suppose, even in the performance of a miracle, any greater interference with the secondary causes than is needed for the accomplishment of the required results. It is remarkable to what an extent the miracles of the Bible are subordinate to this supposed Law of Parsimony, differing in this respect most strikingly from all other purported miracles. It is in this sobriety of the biblical narratives, making only moderate demands upon the direct agency of the Creator, and calling for only a limited disturbance of the course of nature, that we find one of our strongest arguments for their truthfulness.

Human nature has its manifest weaknesses and limitations. The idea of the presence of God's direct agency in the accomplishment of objects is one which, when entertained, cannot but overpower the human imagination. It is therefore certain to be the case that, when a miraculous account is free to be embellished by legendary accretions or mythological fancies, it will become grotesque, and unable to bear the scrutiny of scientific examination. It is therefore a remarkable confirmation of the biblical miracles in general, especially of those which seem to make most demand upon the direct agency of God for their production, that they have been provided for in the general course of nature, 
I20 Physical Preparation for Israel in Palestine.

and involve that minimum amount of direct interference with it which is in analogy with the facts coming under the observation of man respecting his own ability to control these forces.

Before subjecting to examination the more striking miraculous events in Israel's history connected with the physical conditions of the Jordan Valley, it will be profitable to get before our minds a general view of the geological features of Palestine, which have played so important a part in all the history, both ancient and modern, of that remarkable land.

THE GREAT “FAULT" OF THE JORDAN VALLEY.

The special mission of Israel demanded isolation in a peculiar country. Otherwise the people would have been amalgamated with the more numerous, more powerful, and more civilized heathen around them, and their exclusive religious development would have been rendered extremely difficult, if not impossible. At the same time, if their religion was to become universal, the theater of historic development must be at a pivotal point of the great national movements of the world. Both these ends were secured in Palestine by a remarkable combination of geological and physical forces which has commanded the admiration of all profound students of the subject. 
The great "fault" of the Jordan Valley was pronounced by Humboldt " the most remarkable geological feature anywhere to be found in the world"; while Karl Ritter, in his elaborate geographical publications, ever returned to this cleft in the earth's surface, as the most significant fact in the natural history of the globe. This "fault," or fracture in the crust of the earth, extends from Antioch, on the Orontes River, in Syria, to the south end of the Gulf of Akabah, a distance of about one thousand miles. Indeed, geologists now trace it through the Red Sea, and into the lakes of Central Africa. The Lebanon Mountains, Western Palestine, and the Desert of Sinai are on one side of it. The Anti-Lebanon Range and the elevated plains of Moab and Northern Arabia are on the other side. Along the whole dividing line the rocky strata were fractured, and the eastern edge of the western portion slipped down, while the western edge of the eastern mass was elevated.

The depression is most pronounced in the valiey of the Jordan and the Dead Sea. Lake Huleh and the marshy plain extending north to Casarea Philippi are almost exactly at sea-levei'; but Lake Galilee is more than 6oo feet, and the Dead Sea I,292 feet, below the lcrel of the Mediterranean. In its deepest place the bottom of the Dead Sea is 2,600 feet below ocean-level, 
122 Physical Preparation for Israel in Palestine.

and since the heights of Moab and those near Hebron are more than 3,000 feet above the Mediterranean, it follows that the bottom of the Dead Sea is depressed nearly 6,ooo feet below the general land-level. The rock strata on the surface of the plains of Moab correspond to those on the western margin of the Jordan Valley and of the Dead Sea. Western Palestine is a gigantic arch of rock strata, with Shiloh, Jerusalem, and Hebron on its summit, its eastern foot at the bottom of the Dead Sea, and its western base below the plains of Philistia on the Mediterranean.

The western arch, however, has one remarkable interruption in Palestine. This appears in the plain of Esdraelon, which occupies a "cross-fault," extending from the Jordan a little south of Lake Galilee to the Mediterranean at the north end of Mount Carmel. Nazareth lies a little to the north of this cross-fracture, while the Mount of Precipitation, over which his fellow-townsmen were on the point of casting Jesus, is a portion of the northern cliff, facing Esdraelon, produced by the cross-fault. Mount Tabor, a few miles to the east, is an outlying mass of rock which did not settle with the rest of the valley, and is still connected by a low ridge with the main mass to the north.

The summit of the valley of Esdraelon, between Mount Tabor and Jezreel, is only about two hundred 
Physical Preparation for Israel in Palestine. 123

feet above the Mediterranean. The depression, therefore, affords the natural line of communication between the shore of this sea and the country east of the Jordan. This was the main route followed by the caravans from the valley of the Euphrates through Damascus to th: Mediterranean at Acre, and thence along the shore to Egypt. It was this which made the valley of Esdraelon the great battle-field between the east and the west. Recently an English company has built a railway from Acre through this valley to the Jordan, and thence to Damascus. Thus, from first to last, it has been a great highway for the nations.

Yet, upon either side, the ascent to the hills is so rapid, and the country so inaccessible, that there has been little temptation for military occupation by foreigners. When Napoleon led his expedition from Egypt to Syria, he established his headquarters for a while on the plain at Ramleh, near Jaffa, and later besieged Acre, and made his headquarters near Jezreel; while his ablest general, Kléber, fought an important battle at the base of Mount Tabor. Meanwhile Jerusalem was left undisturbed in its isolated position among the mountains of Judxa. When asked why he did not capture Jerusalem, Napoleon replied that it was so out of the way that it was of no general military significance. There can be no question, that the warning of 
12+ Physical Preparation for Israel in Palestine.

the prophets against alliances with the great nations in the valleys of the Nile and Euphrates conformed to the highest principles of both military and political wisdom.

- There was little motive for Assyria to capture Jerusalem, except as she was an ally of Egypt. Her strength was in the natural independence of her isolation.

Next to the Caucasus, Judxa is, from a military point of view, one of the most easily defended regions in the world. The approaches from the west are through steep and circuitous mountain gorges, in which an attacking army is in constant peril from surprises. The trails from Samaria to Jerusalem are, even now, almost impassable to horses, while the desert and difficult roads protect it from the south. Joshua's march from Jericho up the valley to the summit at $\mathrm{Ai}$ and Bethel, a few miles north of Jerusalem, exhibited the perfection of military tactics. From this point of vantage he could sweep along the central ridge to the south, and easily occupy the main positions of importance. Providence was not altogether blind in leading the children of Israel through Moab to the head of the Dead Sea and to the passes that lead thence to the central part of the Promised Land.

North of the valley of Esdraelon the land was almost equally protected. The approach to Lake Galilee by the Jordan Valley is difficult. The entire east-and-west 
"fault" facing Esdraelon from the north presents a precipitous front which is easily defended. The mountains on both the east and the west side of the valley, beginning at the south end of Lake Galilee and extending to the ancient Dan, are lofty, and inaccessible to a military force; while north of Dan the valley between Lebanon and Mount Hermon is so deeply filled with débris of a recent volcanic eruption that it is practically impassable. The Litany River, which rises near Baalbeck and flows south through the valley between Lebanon and Anti-Lebanon, as though it would join the waters of the Jordan Valley, meets the barrier, and suddenly turns at a right angle to enter the Mediterranean near Sidon. The observant traveler cannot fail to be impressed with the completeness of this barrier as he crosses its southern projection near Dan, and takes a glance at the successive steps with which the volcanic material rises across the valley to the north.

Thus, with this barrier of rough basaltic rocks to the north, the precipitous mountain walls on the east and west, and the desert on the south, Palestine was specially prepared to be the home of a "peculiar people." At the same time the great highway between the east and the west passed through its center, but so walled in that there was little temptation for an armed force to interfere with peaceable people on either side. So that, as 


\section{i 20 Physical Preparation for Israel in Palestine.}

Origen forcibly maintained, Palestine, though insignificant in itself, was so centrally situated that it was the fittest of all places for the dissemination of Christianity to the ends of the earth.

\section{THREE GREAT NIIRACLES.}

The falling of the walls of Jericho, the parting of the waters of the Jordan, and the destruction of Sodom and Gomorrah are three notable miracles upon which the physical history of Palestine sheds much light. All these seem to be directly connected with the natural causes which have produced the "great Jordan Fault," and which render the region specially subject to earthquakes.

The Falling of the $W$ alls of Jericho.-This striking phenomenon can easily be referred to an earthquake for its secondary cause.

The preliminary report of the State Earthquake Investigation Committee appointed immediately after the catastrophe at San Francisco, on the 18 th of April, I got, sheds some interesting light upon the somewhat similar catastrophe at Jericho three thousand years ago. Professor A. C. Lawson, of the State University of California, was chairman of the committee, and there were associated with him a number of the most eminent geologists of the country. In reading their report, 
one can but be remarkably impressed by the similarity of conditions in the valley of the Jordan and along the coast of California. In California, as in the valley of the Jordan, a long "fault" is to be observed running parallel with the Coast Range for a distance of many hundred miles. Along this fault the dislocation of the strata amounts to many hundred feet. According to the Commission, probably every movement on this line produced an earthquake, the severity of which was proportioned to the amount of movement.

"The cause of these movements in general terms is that stresses are generated in the earth's crust which accumulate till they exceed the strength of the rocks composing the crust, and they find relief in a sudden rupture. This establishes the plane of dislocation in the first instance, and in future movements the stresses have only to accumulate to the point of overcoming the friction on that plane and any cementation that may have been effected in the intervals between movements. The earthquake of the i 8th of April, I906, was due to one of these movements" (p. IO).

For a distance of one hundred and eighty-five miles the effect of the movement was clearly traced. The observed displacement was both horizontal and vertical. In many cases one side of the fault was shoved past the other horizontally for a distance of fifteen or sixteen feet, and in one case a roadway was found to have 
I28 Physical Preparation for Israel in Palestine.

been differentially moved twenty feet. This would produce the circular motion, so often referred to by observers, which was specially destructive of loosely constructed stone buildings. A correspondent writes that the bricks in his chimney were scattered like grain from the hand of a sower. At the same time there was a vertical movement of several feet. A striking result of the investigation is that the most destructive effects were found on made land, and on sedimentary deposits adjoining the main line of fracture. In the words of the report,-

"Within the area of destructive effects, approximately four hundred by fifty miles in extent, the intensity varied greatly. There was a maximum immediately o: the rift line. Water pipes, conduits, and bridges crossing this line were rent asunder. Trees were uprooted and thrown to the ground in large numbers. Some trees were snapped off, leaving their stumps standing, and others were split from the roots up. Buildings and other structures were in general violently thrown and otherwise wrecked, though some escaped with but slight damage. Fissures opened in the earth and closed again, and in one case reported a cow was engulfed.

"A second line of maximum destruction lies along the floor of the valley system of which the Bay of San Francisco is the most notable feature, and particularly in the Santa Rosa and Santa Clara valleys. Santa 
Rosa. situated twenty miles from the rift, was the most severely shaken town in the State and suffered the greatest disaster relatively to its population and extent. Healdsburg suffered to a nearly similar degree. San José, situated thirteen miles, and Agnews, about twelve miles from the rift, are next in the order of severity. Stanford University, seven miles from the rift, is probably to be placed in the same category. All of these places are situated on the valley floor and are underlain to a considerable depth by loose or but slightly coherent geological formations, and their position strongly suggests that the earth waves as propagated by such formations are much more destructive than the waves which are propagated by the firmer and highly elastic rocks of the adjoining hill lands" (p. I3).

"... The most violent destruction of buildings [in San Francisco], as everybody knows, was on the made ground. This ground seems to have behaved during the earthquake very much in the same way as jelly in a bowl, or as a semi-liquid material in a tank. The earth waves which pass through the highly elastic rocks swiftly with a small amplitude seem in this material to have been transformed into slow undulations of great amplitude which were excessively destructive" (p. 15 ).

In the light of all this, it is important to observe that the city of Jericho stood upon the deep, recent, unconsolidated sedimentary deposits which fill the valley of tle Jordan. The conditions are strikingly like those 
130 Physical Prepartaton for Isrcei in Palestine.

existing in the vicinity of San Francisco, where the greatest destruction occurred during the recent catastrophe. The brief account in Joshua is very lifelike:-

"So the people shouted, and the priests blew the trumpets: and it came to pass, when the people heard the sound of the trumpet, that the people shouted with a great shout, and the wall fell down flat, so that the people went up into the city, every man straight before him, and they took the city" (vi. 20).

The reader should not fail to notice that the blowing of the trumpets is not represented by the sacred writer to be the cause of the falling of the walls, but merely a concomitant. We are left to believe that the two events were brought together by divine foresight, and it was in this that the miraculous nature of the event consists. The mine beneath the walls of Jericho was so deeply laid that only divine power and prescience could explode it at the proper time to accomplish its spiritual purpose.

The Parting of the Whaters of the Jordan.-CThe biblical account reads as follows:-

"Joshua iii. 13 And it shall come to pass, when the soles of the feet of the priests that bear the ark of Jehovah, the Lord of all the earth, shall rest in the waters of the Jordan, that the waters of the Jordan shall be cut off, even the waters that come down from above; and they shall stand in one heap. 
"It And it came to pass, when the people removed from their tents, to pass over the Jordan, the priests that bare the ark of the covenant being before the people; 15 and when they that bare the ark were come unto the Jordan, and the feet of the priests that bare the ark were dipped in the brink of the water (for the Jordan overfloweth all its banks all the time of harvest), if that the waters which came down from above stood, and rose up in one heap, a great way off, at Adam, the city that is beside Zarethan; and those that went down toward the sea of the Arabah, even the Salt Sea, were wholly cut off; and the people passed over right against Jericho. 17 And the priests that bare the ark of the covenant of Jehovah stood firm on dry ground in the midst of the Jordan; and all Israel passed over on dry ground, until all the nation were passed clean over the Jordan."

This is certainly a very simple and straightforward description of a natural phenomenon. There is nothing fantastic about it, and nothing incongruous with the surrounding conditions. It is said that the waters from above, that is, up stream, rose up and extended as far as the city of Adam, a distance of several miles, and that the supply of water was cut off that formerly ran down to the Salt Sea. This is a very accurate account of what would occur if suddenly a dam was thrown across the stream, some little distance above, ponding the water back on that side, and cutting off the supply 
132 Physical Preparation for Israel in Palestine.

below. When first visiting the scene, I was greatly surprised to see that I had not read the account with sufficient care to appreciate its simplicity and accuracy.

There are two natural agencies that at this point could easily have produced the phenomena here described. By some it has been thought that the obstruction was caused by a land-slip somewhere above, which temporarily cut off the water below. But it is equally possible that the obstruction was produced by a gentle swell of the land across the channel pushed up by an earthquake.

A similar interruption of the waters of the Columbia River, in Oregon, is known to have occurred at the Cascades, where an old channel was permanently obstructed by an immense land-slide, producing a lake above, whose outlet is still over the rocks, which causes the cascade. IVe can give no better description of the phenomena than by quoting, from Science for 1887 , the words of Major C. E. Dutton, for a long time a prominent member of the United States Geological Survey.

"The Columbia enters the Cascade barrier three or four miles below the Dalles. The platform of that range here has a width of eighty miles. From the Dalles to the Cascade Locks, a distance of over fifty miles, the Columbia River flows as a broad, deep, quiet stream, with a sluggish current at low water. Its course re- 


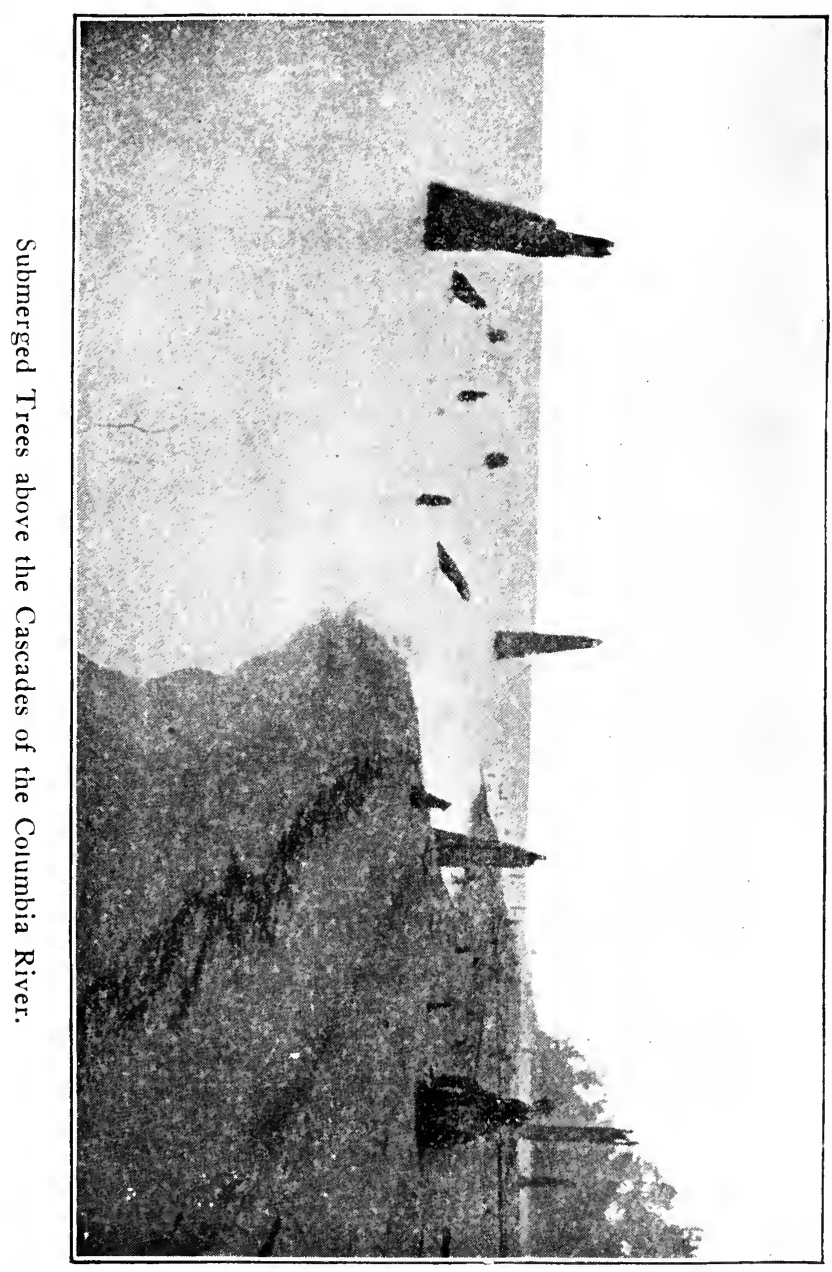




\section{Physical Preparation for 1srael in Palestine.}

sembles that of the Hudson through the Highlands; and this fact is at once suggestive, because the passage of rivers through mountain ranges is generally swift, and broken by many rapids. If it is otherwise, there is almost certainly an interesting reason for it. The Cascade Locks are situated almost exactly on the axis of the Cascade range. Here is a cataract which has always been an insurmountable obstacle to navigation; for, within a distance of a few hundred yards, the river makes a descent of about thirty feet. The government is now building a short canal with large locks, to enable steamboats from below to reach the still waters above. Beginning at a point about a mile and a half above the cataract, the traveler, as he sails up the river, observes many old stubs protruding from the water and from the sand-banks, laid bare during the low stages of the river. They are seen for a distance of thirty miles, recurring at frequent intervals, here clustered thickly together like the piles of an old wharf whose superstructure has decayed and vanished, there with wide intervals between them. During high water these tree-trunks are entirely submerged. An examination of the wood serves to identify them with the living species of fir which form the forests upon the mountains and cliffs round about.

"These submerged trees, together with the long still reach of water above, at once suggest that an obstacle has been placed athwart the stream, forming a dam which converted the river valley above it into a long, 
narrow lake, and that the rising water submerged an old forest of which these trees are the vestiges. Indeed, this is the only explanation which suggests itself. It is strongly corroborated by many other circumstances which may not be enlarged upon here. No geologist who has visited the locality has ever doubted, so far as I know, that this is, in general form, the true explanation. The only question which arises is about the nature of the obstacle which has dammed the river" (pp. 82-83).

Of tîree possible explanations we will note, first, that of Major Dutton, who supposes at the Cascades a post-glacial " uplift of the entire platform athwart the river valley in the shape of a very flat anticlinal arch. The width or span of this arch is about five and one-half miles, and the eastern branch of the flexure is steeper than the western." The river has now cut a gorge so far through the lower part of this obstruction that "it will probably require not more than a century or two for it to have cleared a passage deep enough to drain the slack-water reach above. The work of cutting a passage through the obstruction five and onehalf miles in length is nearly complete" (p. 83). Major Dutton's supposition is that this obstruction was formerly much higher than now, having been much lowered by the action of the river, and that, when it was at the former height, sediment had accumulated 
130 Physical Preparation for Israel in Palestine.

above the obstruction so as to bury the forest, and so preserve it from decay until, through the lowering of the stream, it is now being uncovered.

Dr. S. F. Emmons, another eminent member of the United States Geological Survey, objected to this theory on the ground that an earth movement such as Major Dutton supposes along the axis of the Cascade Mountains could not easily be supposed to have proceeded more rapidly than the corrasion of the stream in lowering the obstruction, and "then conveniently have stopped, so as to allow corrasion to gain its former ascendency over the earth movement."

As a counter theory, Dr. Emmons gave prominence to a tradition, widely circulated among the Indians and Hudson Bay trappers, which relates that "there once existed a natural bridge at the Cascades, and that the ancestors of the present tribes (probably at no very distant period) used to cross the river here dry shod," and that this bridge at length collapsed through the effect of the undercutting of the stream, and so formed the obstruction which now causes the Cascades. So generally disseminated is this tradition that it is made to play an important part in a popular novel, whose scenes are mostly laid in that region. But the theory can be best stated in Dr. Emmons's own words.

"At the time when the general cutting of the $\mathrm{Co}$ - 
lumbia had reached about the level of the present flood. plain at the Cascades, through some crack or other natural opening its waters found a passage into the underlying conglomerate bed, which, being permeable, allowed a passage of this water down stream to a point in the bed itself where it outcropped at or above the level of the lower part of the stream. Such a passage, once established, would be rapidly enlarged by the force of such an overlying mass of water as the Columbia River; and to those familiar with the corrading force of water, as shown in the stream action of western rivers, it must readily be apparent that it would soon become large enough to take in the whole stream; that thus for a certain distance the whole Columbia rould run underground, like the so-called 'Lost Rivers,' which are still found under the basalt flows of the Snake River plains. Thus would have been formed the natural bridge spoken of by the Indians. Moreover, by this lowering of its bed at this point, the bed of the river above would have been correspondingly lowered, and tree-growth would have gradually extended down to the water's edge, as it does at present.

"Meantime the corrasion of this underground stream would gradually wear away the supports of the overhanging sheet of basalt, until at length they became inadequate to hold it up; and when they fell, the underground passage would have been suddenly filled, the river dammed up to the present level, and the stream also backed up so as to cover the roots of and thereby 
138 Physical Preparation for Israel in Palestine.

kill the trees along the lower part of its banks. Such is essentially the present condition of the stream, for the broken masses of the basalt which form the present stream bed at the Cascades resist the wearing-away of the water better than did the conglomerate, and the river above the Cascades still stands at a higher ievel than it did before the falling-in of the basalt bridgre" (p. 157 ).

The third theory is one presented by Dr. J. S. Newberry, an equally eminent authority, who visited the place in 1855 , in connection with the Pacific Railroad survey, and is one which Mr. S. Prentiss Baldwin and I were independently led to adopt when we visited the region in 1890 , and of which the accompanying photographs seem to be a complete demonstration. According to this theory, the Columbia River had, before the growth of the buried forest, cut a gorge completely through the obstruction presented by the anticlinal arch referred to by Major Dutton; so that there was a gradual descent all the way from the Dalles to the section of the river which is below the Cascades. But this channel, where it was comparatively narrow at the Cascades, was finally obstructed by an immense landslide from the south, which turned the water of the river into its present course over the rocky bed which forms the Cascades. According to this supposition, the 





I 40 Physical Preparation for Israel in Palestine.

trees which had grown down the bank covering the old lower flood-plain above the Cascades were submerged and killed as they frequently are in reservoirs made by artificial means.

Since the trees are still undecayed, it would follow that their submergence did not occur more than one hundred or two hundred years ago, for this longer period is the extreme limit that could be allowed for wood in that wet climate to resist decay. Some such date as this also must probably be given to the origin of the tradition referred to, which might easily arise, even though there was no complete natural bridge at that time, as Professor Emmons supposes. For, according to this theory, the wide expanse now covered by the water as it falls over the Cascades was high and dry, bordered merely by a comparatively narrow channel on the south side. Furthermore, for a brief period after the landslide, there would be a dry passage completely across until the vast reservoir above was filled.

This explanation is supported by the fact that below the Cascades the land on the south side along which the railroad runs is constantly sliding into the river, so as to occasion great solicitude to the engineers who are looking after the safety of the roadbed. Upon going back into the forest between the railroad and the precipitous face of the mountain one finds immense 
long crevasses which have been formed at various times by the slipping down of the whole bank. Finally the accompanying photograph, taken by Mr. Baldwin, in the canal bed when under construction, actually exposes this old channel. It was evident that if the canal had been dug a little farther to the south there would have been no rock obstruction. Professor Newberry's original theory, therefore, seems to be sufficiently well supported to be accepted and taught as a doctrine.

Having studied this problem in the Columbia River somewhat carefully several years before, it was with the conclusions in mind then formed that I entered the Jordan Valley at Jericho, near the ford above the Dead Sea. But, on reaching the river's bank, my attention was instantly arrested by phenomena which rendered plausible the theory of a disturbance by an earthquake.

Near the Pilgrims' Bathing-Place, the east bank of the river is so eroded by the stream as to present a perpendicular face. This consists of fine sediment, about fifty feet thick, which has been deposited by the river when standing at a higher level, and subsequently channeled by it when the land-level was relatively higher. But what was still more significant, was that there were clear indications of three changes of level. First, there had been an elevation of about fifteen feet, during which erosion had proceeded to that extent. 


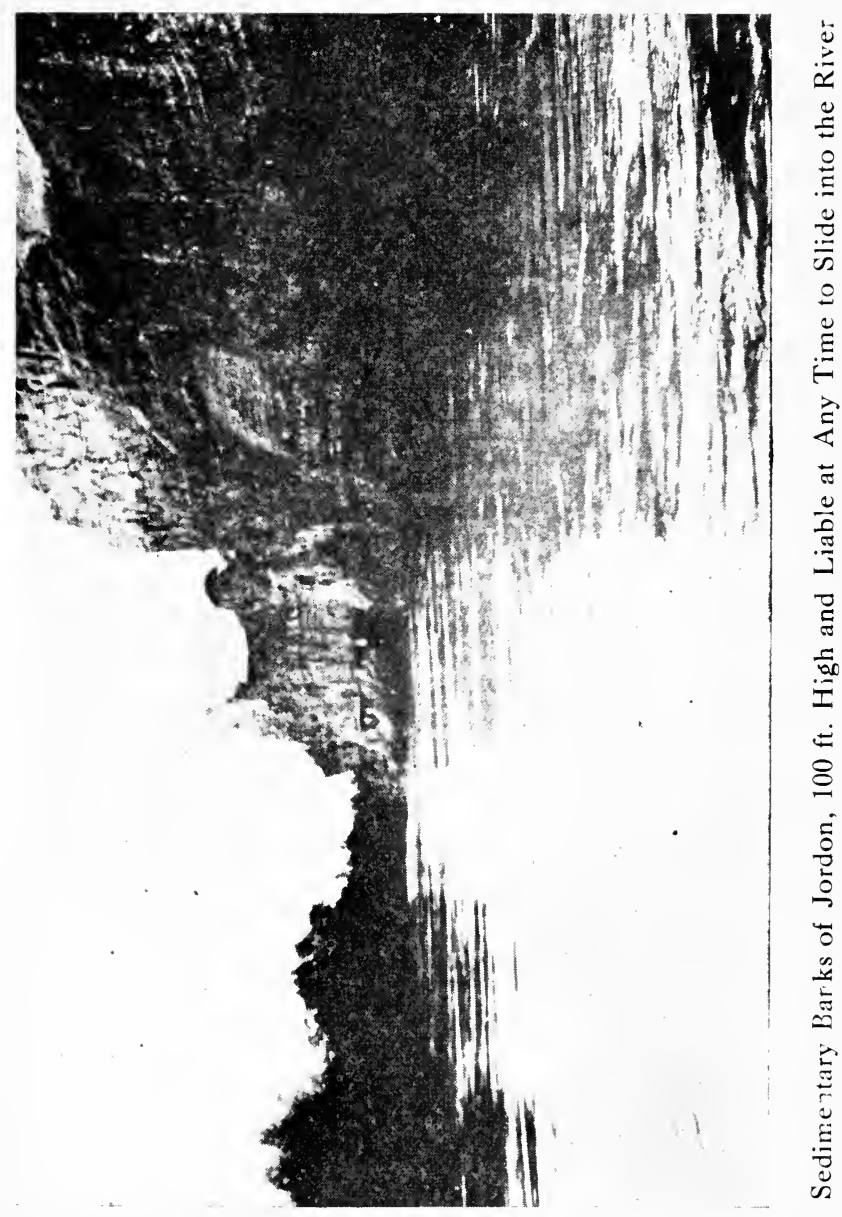


Then there had been a return of the water to the higher level ard a re-sedimentation up to the old limit. This was followed by a re-channeling of the whole, during which the river had cut through both the later and the upper sediment, and also for fifteen feet lower down. ${ }^{1}$

The most natural interpretation of this succession is, that, after the channel had been cut down the first fifteen feet, there was an elevation, through subterranean forces, of the bed of the stream a mile or two below. This would dam up the water temporarily, and afford a dry crossing-place for a few hours, or even longer, and make the waters, seem to pile up above, as described in Josh. iii. I3-17. When, however, at length, the water began to run over the obstacle to its progress, there would be opportunity to refill with sediment a part of its bed above; so that, on later reërosion to its present level, it would present the phenomena now to be observed. I have not evidence sufficient to form an opinion as to whether the episode in the river's history brought to light by these facts relates to the same epoch with that of the miracle recorded in the Pentateuch; but it certainly gives a plausible explanation of the probable secondary causes used in accomplishing it.

Here, again, on this supposition, there was a particular use, for a moral purpose, of the subterranean forces which have so long operated in producing the great de- 


\section{It+ Physical Ireparation for Isract in Palestine.}

pression of the Jordan Valley. If one contends that the exhibition of this force at that time was foreordained he must still bring in prophetic, or divine, foresight to secure the presence of the hosts of Israel there at the precise juncture, and this involves all the essential elements of a miracle.

The Destruction of Sodom and Gomorrah.-The probable secondary cause employed in the destruction of Sodom and Gomorrah was the ignition by an earth. quake of a vast underlying reservoir of gas and petroleum. The Upper Cretaceous strata which, in the great Jordan Fault, have been thrown down below the level of the Dead Sea, contain much bituminous; limestone stich as raturally gives rive to pools of petroleum and inflammable was. Familiarity with the gas and oil regions of the Lnited States, and a recent visit to the still more remarkable oil-fields at Baku, on the Caspian Sea, made the description of the destruction of Solom ard Gomorrah seem excedingly natural and lifelike.

Professor B. K. Emerson," one of our most eminent geolonists, describes the region about the Dead Sea as one

"where sulphur, deposited by many hot springs, is abundant in the clay, and where bitumen oozes from every crevice of the rock, and every earthquake dislodges great sheets of it from the bottom of the lake, 
Physical Preparation for Isracl in Palestine. $\mathrm{I}_{i j}$

where Arabs still dig pits for the 'stone of Moses' to gather in, and sell it in Jerusalem, and where, in that most ancient fragment of the Pentateuch, four king: fought against five, and the kings of Sodom and Gomorrah slipped in the slime-pits and fell. One who has read of the burning of an oil well on Oil Creek, or in Apscheron will have a clear idea of the catastrophe which overtook the cities of the plain where the Lord rained upon Sodom and upon Gomorrah brimstone and fire out of heaven.

"Following the latest extremely interesting researches of Blankenkorn, ${ }^{3}$ we may picture the upper cretaceous plateau of Judea,-an old land, cleft at the end of the Tertiary by many faults, between which a great block sank to form the bottom of this deep sea. It carried down in the fossiliferous and gypsum-bearing beds the source of the bitumen and the sulpher. ... In the earlier portion of this last or post-glacial stadium, a final sinking of a fraction of the bottom of the trough. near the south end of the lake, dissected the low salt plateau, sinking its central parts beneath the salt waters, while fragments remain buttressed against the great walls of the trench forming the plains of Djebel Usdum and the peninsula El Listan, with the swampy Sebcha between. . . . It exposed the wonderful eastern wall of Djebel Usdum: seven miles long, with $30-45$ meters of clear blue salt at the base, capped by I25-140 meters of gypsum-bearing marls impregnated with sulphur, and conglomerates at times cemented with bitumen. 
146 Physical Preparation for Israel in Palestine.

It was this or some similar and later sinking of the ground, at the time when geology and history join, which, with its earthquakes, overthrew the cities of the plain and caused the outpour of petroleum from the many fault fissures and the escape of great volumes of sulphurous and gaseous emanation, which, ignited either spontaneously, by lightning, or by chance, furnished the brimstone and fire from heaven, and the smoke of the land going up as the smoke of a furnace which Abraham saw from the plains of Judea."

An oil-well opened in Texas in 1900 sent up to a height of two hundred feet a stream of oil six inches in diameter, and poured out 25,000 barrels of oil per day. The late Professor Edward Orton reported that he had seen the pressure-gauge on a gas well in Central New York register 2,600 pounds to the square inch. The pressure on the piston of a locomotive rarely goes much over one hundred and fifty pounds to the square inch. The oil-fields at Baku on the Caspian Sea are limited to a few square miles, yet this small area produces as much as all the American fields combined, about Ioo,ooo,oco barrels annually. When a well is sunk a few hundred feet to the subterranean reservoir, the oil comes up with such force that there is no possibility of controlling it. The drills are thrown out by the pressure, together with stch quantities of stones, that the 


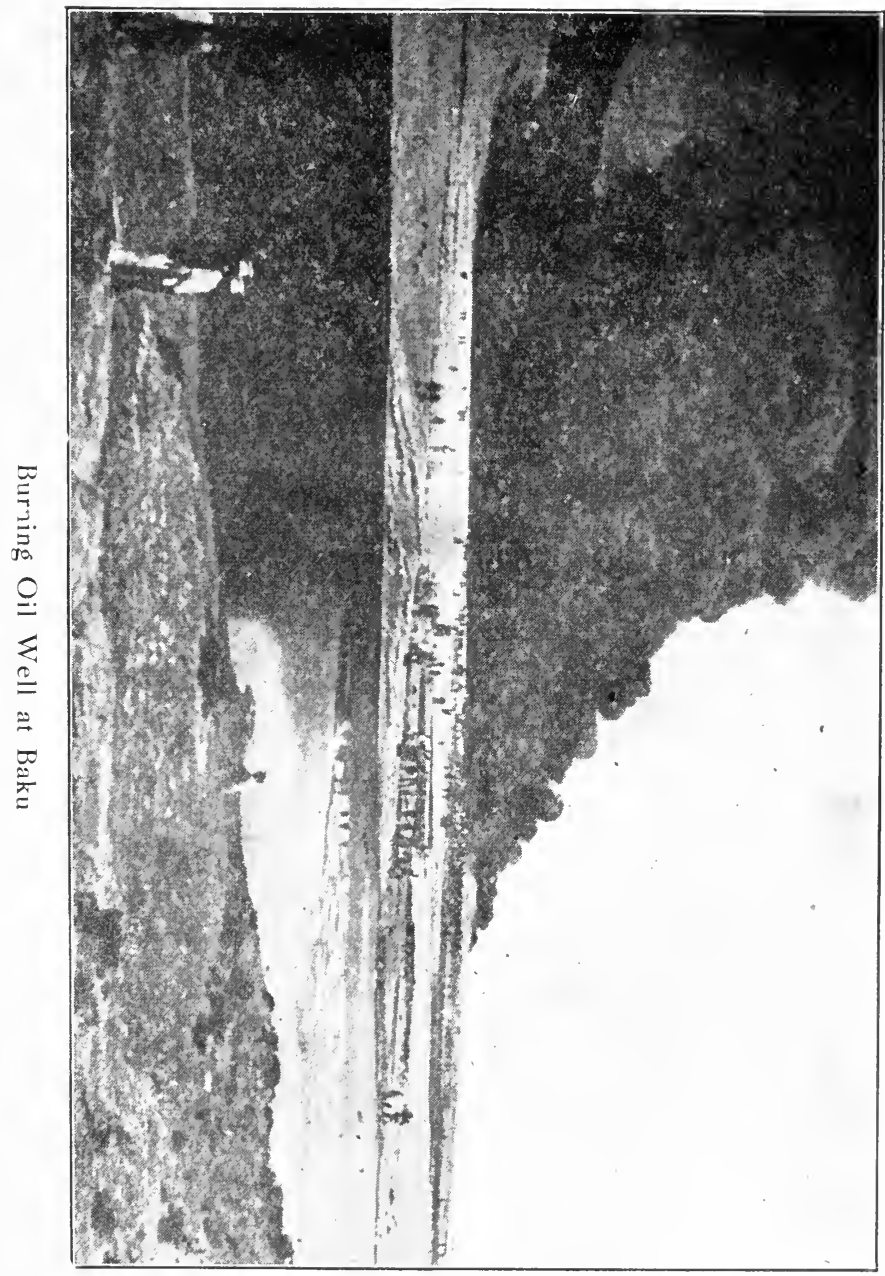


I+8 Physical Preparation for Israel in Palestine.

derricks are battered to pieces, and a cone of débris is piled up around the orifice. Meanwhile the oil is caught by dams in the open fields.

The reports of burning oil-wells near Baku exceed the highest flights of the imagination:-

"In the spring of $I 90 I$, an immense fountain was struck by Messrs. Mantasheff, which commenced wit! such violence that the roar was heard all over the oil fields, and many people were aroused from their sleep. The derrick was blown to splinters at the first outbreak, and a vertical column of oil and sand rose to a height of several hundred feet, flinging stones in all directions and drenching the neighborhood with oil. The derrick and engine-house were soon hidden from view by a large mound of sand, from the center of which the huge fountain arose, and all the houses, workshops, etc., in the district were covered with oil. Every fire within a radius of several hundred yards had to be extinguished, and the whole of the valuable properties surrounding this plot were for many days shut down completely. Houses in the immediate vicinity were flooded out and rendered uninhabitable, and within a large circuit the drain-spouts from the roofs of the buildings were pouring streams of oil into the roadways. The main roads were flooded with oil several feet deep in places, and the oil in some cases was more tian a foot deep in the rooms of the dwelling-houses, which the inhabitants had been forced to vacate speeci- 
ily, and the roofs of which had in many cases collapsed from the weight of sand upon them.

"An even more destructive fountain was one of the Baku Oil Co., at Bibi-Eibat, in 1901; this commenced to spout with terrific force from a great depth, completely wrecking the derrick, and, after rising to a considerable height, was entirely at the mercy of the winds. This fountain is estimated to have yielded about I,OOO,OOO poods [about IOO,OOO barrels] daily for the first few days, during which time the oil flooded all the surrounding properties, and caused a total cessation of work over most of the Bibi-Eibat oil field. A changeable wind drove the oil alternately to different parts of the field, deluging miles of land, and blackening and damaging every building within its reach. A stiff breeze drove the oil towards Baku, and almost every house in Baieloff, a suburb of Baku, was blackened and soaked with petroleum, including the Russian church, public buildings, and private residences. Oil spray was falling over Baku three miles away, and sheets of note-paper exposed to the air near the railway station at almost five miles' distance were spotted with oil particles. The ships in the harbor did not escape, and the gunboats of the Caspian fleet, which are painted white, were blackened and made unrecognizable by the drifting oil spray. Although some I 5,000, ooo poods [ $1,500,000$ barrels] of oil were secured, the high duty payable to the Government, and the enormous demands for compensation from persons who suffered damage- 
150 Physical Proparation for Israel in Palestine.

for practically the whole of the village of Baieloff baci to be cleaned and the houses repainted-left but little surplus for profit.

"Perhaps the greatest fountain ever recorded in the world's history was that resulting frow Mr. Assadu laieff's first boring in Romany [near Eaku]. 'This weli was the first-bored hole in the district, and the oii flowed almost incessantly for years, yielding, it is reported, between 50,000,000 and 60,00r,000 poods [5,000,000 or 6,000,000 barrels]." *

As already shown, the region of the Dead Sea is a partially exhausted gas and oil field, over a deep fissure in the earth leading far down towards its central fires. The description of the destruction of Sodom anci Gomorrah reads almost exactly like that of some of the scenes just described, and is too sober and realistic to have been invented. The whole story is told in a few words-

"Genesis xix. 24 Then Jehovah rained upon Sodom and upon Gomorrah brimstone and fire from Jehovah out of heaven; 25 and he overthrew those cities, and all the Plain, and all the inhabitants of the cities, and that which grew upon the ground. 26 But his wife looked back from behind him, and she became a pillar of salt. 27 And Abraham gat up early in the morning to the place where he had stood before Jehovah: 28 and he looked toward Sodom and Gomorrah, and toward all 
the land of the Plain, and beheld, and, lo, the smoke of the land went up as the smoke of a furnace.

" 29 And it came to pass, when God destroyed the cities of the Plain, that God remembered Abraham, and sent Lot out of the midst of the overthrow, when he overthrew the cities in which Lot dwelt."

From the heights of Hebron, about thirty miles away, where Abraham was, the plain about the end of the Dead Sea could not be seen. Instead, he saw the smoke of the catastrophe ascending " as the smoke of a furnace." Nothing pertaining to this description has the air of fiction. There is nothing fantastic or extravagant about it, except as the facts naturally entering into the history are, to ill-informed persons, stranger than fiction.

Nor is the fate of Lot's wife altogether anomalous. The eruptions of gas and oil are often accompanied with eruptions of salt slime such as presumably enveloped her as she lingered behind. The description of her death is certainly very sober, and unconnected with the fantastic elements which have been attached to it in many popular representations. The phrase "pillar of salt" is more definite than the original word demands. Mound of salt would probably more nearly express the idea. But salt is an abundant constituent of the rocks around the Dead Sea. The lower strata 
152 Physical Preparation for Isract in Palestine.

of Jebel Usdum at the south end consist of solid salt one hundred and fifty feet thick. The pillars left by the erosion of this stratum have given shape to the popular conception. A mound of salty slime exuded from an orifice opened by an earthquake would be a most common accompaniment of such a catastrophe. ${ }^{5}$

Again we repeat, that this explanation of the miracle, while it strongly confirms the truth of the record, does not in the least degree impair the miraculous character of the event. The use of these natural forces to accomplish the moral purposes of the catastrophe involves the direct action of the Creator as really as the aiming and firing of a gun at a mark does that of a free human agent. The conjunction of this natural catastrophe with this particular epoch in the history both of Lot and of Abraham could not have been accidental. If the divine agency was not directly involved in setting free at that instant the physical forces producing the catastrophe, it was involved in securing the relation of Lot and Abraham to it. But it is as easy to believe that the Lord directly used the forces prepared as that a huntsman purposely fires a gun.

Before passing to the story of the Flood, it will be in place briefly to consider the fourteenth chapter of Genesis,- - a document so striking and full of apparentl; 
improbable statements that it most readily lends itself to our purpose. It reads as follows :-

"Genesis xiv. I And it came to pass in the days of Amraphel king of Shinar, Arioch king of Ellasar, Chedorlaomer king of Elam, and Tidal king of Goiim, 2 that they made war with Bera king of Sodom, and with Birsha king of Gomorrah, Shinab king of Admah, and Shemeber king of Zeboiim, and the king of Bela (the same is Zoar). 3 All these joined together in the vale of Siddim (the same is the Salt Sea). 4 Twelve years they served Chedorlaomer, and in the thirteenth year they rebelled. 5 And in the fourteenth year came Chelorlaomer, and the kings that were with him, and smot: the Rephaim in Ashteroth-karnaim, and the $\mathrm{Zu}$ ciin in Ham, and Emim in Shaveh-kiriathaim, 6 and the Horites in their mount Seir, unto El-paran, which is ny the wilderness. 7 And they returned, and came to En-misphat (the same is Kadesh), and smote all the country of the Amalekites, and also the Amorites, that dwelt in Hazazon-tamar. 8 And there went out the king of Sodom, and the king of Gomorrah, and the king of Admah, and the king of Zeboiim, and the king of Bela (the same as Zoar); and they set the battle array against them in the vale of Siddim; 9 against Chedorlaomer king of Elam, and Tidal king of Goïm, and Amraphel king of Shinar, and Arioch king of Ellasar; four kings against the five. Io Now the vale of Siddim was full of slime [bitumen] pits; and the kings of Sodom and Gomorrah fled, and they fell there, 


\section{Physical Preparction for Israel in Palestine.}

and they that remained fled to the mountain. II And they took all the goods of Sodom and Gomorrah, and all their victuals, and went their way. 12 And they took Lot, Abram's brother's son, who dwelt in Sodom, and his goods, and departed.

"I3 And there came one that had escaped, and told Abram the Hebrew: now he dwelt by the oaks of Namre the Amorite, brother of Eshcol, and brother of Aner; and these were confederate with Abram. I4 And when Abram heard that his brother was taken captive, he led forth his trained men, born in his house, three hundred and eighteen, and pursued as far as Dan. I 5 And he divided himself against them by night, he and his servants, and smote them, and pursued them unto Hobah, which is on the left hand of Damascus. I6 And he brought back all the goods, and also brought back his brother Lot, and his goods, and the women also, and the people.

" I 7 And the king of Sodom went out to meet him, after his return from the slaughter of Chedorlaomer and the kings that were with him, at the vale of Shaveh (the same is the King's Vale). 18 And Melchizedeck king of Salem brought forth bread and wine: and he was priest of God Most High. I9 And he blessed him, and said, Blessed be Abram of God Most High, possessor of heaven and earth: 20 and blessed be God Most High, who hath delivered thine enemies into thy hand. And he gave him a tenth of all. 2 I And the king of Sodom said unto Abram, Give me the persons, 
and take the goods to thyself. 22 And Abram said to the king of Sodom, I have lifted up my hand unto Jehovah, God Most High, possessor of heaven and carth, 23 that I will not take a thread nor a shoelatchet nor aught that is thine, lest thou shouldest say, I have made Abram rich: 24 save o:ly that which the young men have eaten, and the portion of the men that went with me, Aner, Eshcol, and Mamre; let them take their portion."

Until a few years ago, all this was entirely unconfirmed, but it is now confirmed by a remarkable chain of discoveries, the last of these being the Laws of Khammu-rabi, one of the actors in the scene. This confirmation consists not only in the general coincidences of the documents, but even more convincingly in those minute points of coincidence which only a scientific observer would notice. These are forcibly presented in a recent communication of Professor Sayce to the Expository Times for August, 1906, and are thus summarized by him:-

"( I) Cuneiform documents of the Khammu-rabi age lie behind the Hebrew text.

"(2) The documents were Babylonian. This, however, does not preclude their having been written in Canaan, since the official titles of the years were sent by the home government to the Canaanite as to the other governors. One of these notices, announcing the of- 
156 Physical Preparation for Israel in Palestine.

ficial title of one of the years in the reign of Samsuiluna, the son and successor of Khanımu-rabi, has been found in the Lebanon, and is now in the American College at Beyrût.

"(3) The Hebrew text is a translation, or para. phrase, of a cuneiform original. This is proved by the spelling of Amraphel, Ham, and Zuzim, and the rendering of Uru-Salim by Salem; possibly also by the last syllable of Amraphel and the first syllable of Eshcol. [For example, Amrap is the same as Khammurab, except that, in the latter form, the $A$ is introduced by a guttural sound. "The final $l$ in the Hebrew form may be explained from the title of ilu, 'god,' given to the great king both by himself and by others," or from a misreading of the final syllable, which may be pil or bi.] A paraphrase is less likely than a free translation, since all those who received a Babylonian education were accustomed to translating, more or less literally, from Sumerian. The Canaanite or Hebrew glosses found in the Tel el-Amarna tablets also point to translation in the proper sense of the word.

"(4) The whole chapter belongs to the same period of history and literature.

"(5) The narrative from beginning to end is historical, and is probably ultimately based on official annals.

"(6) The Babylonian proper names have been handed down with remarkable correctness, indicating (a) that the same care was taken in Canaan in copying 
older documents as in Babylonia and Assyria; $(b)$ that the Hebrew translator was conscientious; $(c)$ that the Hebrew text is on the whole to be trusted.

"(7) The spelling of the name of Amraphel is not official Babylonian, that of Chedor-laomer agrees with the curious spelling of the Spartali tablets [discovered by Dr. Pinches, in which Eri-Aku, the Sumerian equivalent of Arioch, is spelled, in the favorite rebus fashion, Eri- $\hat{\mathrm{E}}-\mathrm{kua}$, the servant of the god $\hat{\mathrm{E}}-\mathrm{kua}$, or the moon god. Naturally, therefore, he was called by a portion of his Semitic subjects Rim-Sin, a form expressing the same idea].

“(8) The differences between the Septuagint and the Massoretic texts--the Septuagint readings being usually preferable to the Massoretic on archæological grounds-show that there has been 'corruption' of the Hebrew text since it was first definitely fixed.

"(9) We are therefore justified in believing that still greater differences would be discoverable could we get back to an earlier text, such as it was before the Pentateuch had been reduced to its present form by 'Ezra and the men of the great Synagogue,' who would have done for it what Peisistratus is said to have done for Homer; see 2 Es. xiv. 2I, 22. In this particular chapter, however, the differences, according to (6), would not have been material.

"(I0) The Hebrew translation was made after the conquest of Laish by the Danites in the lifetime of the grandson of Moses, but before Hazeron-tamar had be- 
158 Physical Preparation for Israel in Palestine.

come En-gedi [as was the case when 2 Chron. xx. 2 and Joshua Xv. 62 were written].

"( I I ) As the use of the so-called Phonician alphabet in Palestine and Phønicia cannot be traced archæologically beyond the age of David or Samuel, the Hebrew translation of the cuneiform original may have been made then. Von Hummelauer has pointed out that Deut. xii.--xxvi. I6 represents 'the (not a) book of the kingdom' ( I Sam. x. 25) written by Samuel (Bardenhewer's Biblische Studien, vi. I, 2). That the official records of Israel perished in the destruction of Shiloh by the Philistines (Jer. vii. 12; xxvi. 6), is shown by the loss of the names of the high priests between Phineas and Eli, the list in I Chron. vi. +-15, $50-53$ being taken from the genealogy of Ezra (Ezra vii. I-5) combined with some other genealogy. With the new régime under Samuel we may therefore conjecture that the new alphabet, and probably also the use of the native language, were introduced among the Israelites as they seem to have been at Tyre under Abibal and Hiram I. Samuel himself bears a name of the Khammu-rabi period, Samu-ilu."

It is certainly difficult to believe that a fictitious document could stand the scrutiny of scientific crossexamination so successiuliy as this nas done. 
CHAPTER VI.

\section{TRADITIONS OF 'THE DELUGE.}

Of all biblical miracles, the Noachian Deluge is the one which seems to make the most extravagant demands upon scientific faith. Yet it is this upon which recent geological investigations have shed most light, reducing the marvel to such reasonable proportions that no one need hesitate to accept the biblical story, when properly interpreted, upon the strength of the documentary evidence. At the same time, the sobriety of the biblical narrative and the limitations of its demands to such events as geology now shows to be easily credible both confirm the story itself and guarantee the faithfulness with which the book containing the record has been preserved from legendary and mythological accretions.

COMPARISON WITH OTHER TRADITIONS.

The account of the Flood in Genesis does not stand alone. Similar traditions are found among nearly all the nations and tribes of the world. So wide-spread and persistent are these, that those who have given attention to the subject have found it difficult to resist the conviction that they relate to a common event with 
which the ancestors of all the present population of the world were acquainted in its painful reality.

But, as might be expected, the traditions in general have taken on such local coloring and extravagant proportions that the kernel of truth underlying them has been hopelessly obscured. Among them all, the narrative in Genesis stands out conspicuous for the grandeur and beauty of the divine attributes revealed in connection with the catastrophe, for the simplicity of the style in which the story is related, and for its undesigned conformity with the natural facts incidentally involved in it.

The traditions with which it is most important to compare the biblical narrative are: (I) the one in the cuneiform tablets discovered by George Smith about 1870 and supposed to date at least from 3000 B.c., and (2) the one given by Berosus. For convenience of reference, we place on opposite pages the Bible story and a translation of the cuneiform tablets. ${ }^{1}$

\section{BIBLICAL ACCOUNT.}

"Gen. vi. 5 And Jehovah saw that the wickedness of man was great in the earth, and that every imagination of the thoughts of his heart was only evil continually. 6 And it repented Jehovah that he had made man on the earth, and it grieved him at his heart. 7 And Jehovah said, I will destroy man whom I have created from the face of the ground; both man, and beast, and creeping things, and birds of the 


\section{- CUNEIFORM ACCOUNT.}

'[I] Nûh-napishtim saith to him, even to Gilgamesh:

[2] Let me unfold to thee, Gilgamesh, a secret story,

[3] And the decree of the gods let me tell thee!

[4] Shurippak, a city thou knowest,-

[5] On the banks of the Euphrates it lieth;

[6] That city was full of violence, and the gods within it-

[7] To make a flood their heart urged them, even the mighty gods.

[8] Their father (i.e. adviser: Gen. 45.8) was Anu,

[9] Their counsellor the warrior Bel

[ı] Their throne-bearer Ninib,

[II] Their champion Innugi.

[12] Nin-igi-azeg, even, Ia, had sat (or lurked) near them, and

[13] Their talk (or purpose) he repeated to the reed-fence:

[14] 'Reed-fence, reed-fence! House-wall, hot:se-wall!

[15] Reed-fence, listen! and house-wall give lieed!

[16] Man of Shurippak, son of Ubara-Tutu,

[17] Pull down the house, and build a ship!

[18] Leave goods, seek life!

[19] Property forsake, and life preserve!

[20] Cause seed of life of every sort to go up into the ship!

[21] The ship which thou shalt build,

[22] Exact be its dimensions,

[23] Equal be its breadth and its length!

[2+] On the ocean launch it!"

[25] I understood, and said unto Ia my lord:

[26] 'The command, my lord, which thou spakest thus,

[27] I honour, I will do [it]!

[28] [But wh] at shall I answer the city, the people and the elders?'

[29] Ia framed his mouth and spaketh,

[3o] He saith unto me, his slave:

[3I] ' Ans]wer thus shalt thou make unto them: 
BIBLICAL ACCOUNT-CONTINUED.

heavens; for it repenteth me that I have made them. 8 But Noah found favor in the eycs of Jehovah.

" 9 These are the generations of Noah. Noah was a righteous man, and perfect in his generations: Noah walked with God. Io And Noah begat three sons, Shem, Ham, and Japheth. Ix And the earth was corrupt before God, and thr earth was filled with violence. 12 And God saw the earth, and, behold, it was corrupt; for all flesh had corrupted their way upon the earth.

"I 3 And God said unto Noah, The end of all flesh i: come before me; for the earth is filled with violence through them; and, behold, I will destroy them with the earth. It Nake thee an ark of gopher wood; rooms shalt thou make in the ark, and shall pitch it within and without with pitch. I5 And this is how thou shalt make it: the length of the ark three hundred cubits, the breadth of it fifty cubits, and the height of it thirty cubits. I6 A light shalt thou make to the ark; and to a cubit shalt thou finish it upward; and the door of the ark shalt thou set in the side thereof; with lower, second, and third stories shalt thou make it. 17 And, I, behold, I do bring the flood of waters upon the earth, to destroy all flesh, wherein is the breath of life, from under heaven; everything that is in the earth shall die. 18 But I will establish my covenant with thee; and thou shalt come into the ark, thou, and thy sons, and thy wife, and thy sons' wives with thee. 19 And of every living thing of all flesh, two of every sort shalt thou bring into the ark, to keep them alive with thee; they shall be male and female. 2o Of the birds after their kind, and of the cattle after their kind, of every creeping thing of the ground after its kind, two of every sort shall come unto thee, to keep them alive. 21 And take thou vin: thee of ail food that is eaten, and gather it to thee; and it shall be for food for thee, and for them. 22 Thus did Noal.; according to all that God commanded him, so did he. 


\section{CUNEIFORM ACCOUNT-CONTINUED.}

[32] "Bel hath rejected and hateth me, and

[33] I may no longer dwell in yo[ur] cit[y], and

[34] 'Toward Bel's ground I may no longer turn my face: but

[35] I will [go] down to the ocean, [and] with [Ia] my [lord] will I divell!

[36] [Upon] you it will rain heavily. . . .",

[About twelve lines are broken, or have entirely disappeared.]

[37] On the fifth day I laid down the frame of it;

[38] At its bulwarks (?) its sides were r 40 cubits high;

[39] The border of its top equaled r fo cubits (i.e. every way).

[40] I laid down its form, I figured (or fashioned) it:

[+I] I constructed it in six stories,

[+2] Dividing it into seven compartments;

[43] Its floors I divided into nine chambers each.

[+t] Water-pegs inside it I drove it in (to stop leaks).

[45] I chose a mast (or rudder-pole), and supplied what was necessary:

[+6] Six sars of bitumen I poured over the outside

[47] Three sars of bitumen [I poured over] the inside.

[48] While the basket-bearers were carrying three sars of oil abroad,

[49] I reserved one sar of oil, which the libations (?) consumed;

[50] Two sars of oil the shipmen stowed away.

[5I] For [the men's food] I slaughtered oxen;

[52] I slew [small cattle] every day;

[53] New wine, sesame wine, oil and grape wine,

[54] The people [I gave to drink], like the water of a river.

[55] A feast [I made], like New Year's Day. ... [Five lines.] 
BIBLICAL ACCOUNT--CONTINUED。

"VII. And Jehovah said unto Noah, Come thou and all thy house into the ark; for thee have I seen righteous before me in this generation. 2 Of every clean beast thou shalt take to thee seven and seven, the male and his female; and of the reasts that are not clean two, the male and his female; 3 of the birds also of the heavens, seven and seven, male and female, to keep seed alive upon the face of all the earth. 4 For yet seven days, and I will cause it to rain upon the earth forty days and forty nights; and every living thing that I have made will I destroy from off the face of the ground. 5 And Noah did according unto all that Jehovah commanded him.

" 6 And Noah was six hundred years old when the flood of waters was upon the earth. 7 And Noah went in, and his sons, and his wife, and his sons' wives with him, into the ark, because of the waters of the flood. 8 Of clean beasts, and of beasts that are not clean, and of birds, and of everything that creepeth upon the ground, 9 there went in two and two unto Noalı into the ark, male and female, as God commanded Noah. Io And it came to pass after the seven days, that the waters of the flood were upon the earth. II In the six hundredth year of Noah's life, in the second month, on the seventeenth day of the month, on the same day were all the fountains of the great deep broken up, and the windows of heaven were opened. 12 And the rain was upon the earth forty days and forty nights.

"I 3 In the selfsame day entered Noah, and Shem, and Ham. and Japheth, the sons of Noah, and Noah's wife, and the three wives of his sons with them, into the ark; 14 they, and every beast after its kind, and all the cattle after their kind, and every creeping thing that creepeth upon the earth after its kind, and every bird after its kind, every bird of every sort. 15 And they went in unto Noah into the ark, two and two of all flesh wherein is the breath of life. I6 And they 
CUNEIFORM ACCOUNT-CONTINUED.

[56] [With all that I possessed I fr] eighted it;

[57] With all that I had of silver I freighted it;

[58] With :il that I had of gold I freighted it;

[59] With all that I had of seed of life of every sort [! freighted it] ;

[6o] I put cn board all my family and my clan;

[6r] Cattle of the field, wild beasts of the field, all the craftsmen, I put on board.

[62] A time Samas appointed (saying):-

[63] "When the Lord of Storm at eventide causeth the heavens to rain heavily,

[6+] Enter into the ship, and shut thy door!'

[65] That time came:

[66] The Lord of Storm at eventide caused the heavens to rain heavily.

[67] I drea!ed the appearance of day;

[68] I was afräid of beholding day:

[69] I entered the ship and shut me my door.

[70] For the steering of the ship, to Bezur-Bel the shipman

[7x] The great vessel (deckhouse?) I handed over, with its freight (or gear).

[72] When the first light of dawn appeared,

[73] There rose from the foundation of heaven a black cloud:

[7+] Rimmon in the heart of it thunders, and

[75] [Nebo] and Merodach march before;

[76] The Throne-bearers march o'er mountain and plain.

[77] The inighty Dibbarra (or Girra) wrenches away the helm;

[78] Ninib goes on, pouring out ruin.

[79] The Anunnaki (earth-spirits) lifted torches;

[8o] With their sheen they lighten the world.

[8r] Rimmon's violence reacheth to lieaven;

[82] Whatever is bright he turneth into darkness. 


\section{BIBLIC.AL ACCOUNT-CONTINUED}

that went in, went in male and female of all flesh, as God commanded him: and Jehovah shut him in. 17 And the flood was forty days upon the earth; and the waters increased, and bare up the ark, and it was lifted up above the earth. 18 And the waters prevailed, and increased greatly upon the eartil; and the ark went upon the face of the waters. I9 And the waters prevailed exceedingly upon the earth; and all the high mountains that were under the whole heaven were covered. 20 Fifteen cubits upward did the waters prevail; and the mountains were covered. $2 \mathrm{I}$ And all flesh died that moved upon the earth, both birds, and cattle, and beasts, and every creeping thing that creepeth upon the earth, and every man: 22 all in whose nostrils was the breath of the spirit of life, of all that was on the dry land, died. 23 And every living thing was destroyed that was upon the face of the ground, both man, and cattle, and creeping things, and birds of the heavens; and they were destroyed from the earth: and Noah only was eft, and they that were with him in the ark. 24 And the waters prevailed upon the earth a hundred and fifty days.

"VIII. And God remembered Noah, and all the beasts, and all the cattle that were with him in the ark: and God made a wind to pass over the earth, and the waters assuaged; 2 the fountains also of the deep and the windows of heaver were stopped, and the rain from heaven was restrained; 5 and the waters returned from off the earth continually: and after the end of a hundred and fifty days the waters decreased. + And the ark rested in the seventh month, on the seventeenth day of the month, upon the mountains of Ararat. 5 And the waters decreased continually until the tenth month: in the tenth month, on the first day of the month, were the tops of the mountains seen.

" 6 And it came to pass at the end of forty days, that Noah opened the window of the ark which he had made: 7 And he sent forth a raven, and it went forth to and fro, until the 


\section{CUNEIFORM ACCOUNT-CONTINUED.}

[83]

[84] One day the southern blast.

[85] Hard it blew, and . . . .

[86] Like a battle-charge upon mankind rush [the waters].

[87] One no longer sees another;

[88] No more are men discerned in (described from) heaven.

[89] The gods were dismayed at the flood, and

[90] Sought refuge in ascending to the highest heaven (lit. the heaven of Anu):

[9r] The gods cowered like dogs; on the battlements (of heaven) they crouched.

[92] Ishtar screams like a woman in travail,

[93] The loud-voiced Lady of the gods exclaims:

[94] 'Yon generation is turned again to clay!

[95] As I in the assembly of the gods foretold the evil-

[96] Like as I foretold in the assembly of the gods the evil;-

[97] A tempest for the destruction of my people I foretold.

[98] But I will give birth to my people (again), though

[99] Like the fry of fishes they fill the sea!'

[roo] The gods because of the Anunnaki wept with her;

[ror] The gods were downcast, they sate a-weeping;

[IC2] Closed were their lips . . . .

[103] During six days and nights

[10+] Wind, flood, storm, ever more fiercely whelmed the land.

[105] When the seventh day came, storm (and) flood ceased the battle,

[106] Wherein they had contended like a host:

[107] The sea lulled, the blast fell, the flood ceased.

[Io8] I looked for the people [udma], with a cry of lamentation;

[109] But all mankind had turned again to clay: 


\section{BIBLICAL ACCOUNT-CONTINUED.}

waters were dried up from off the earth. 8 And he sent forth a dove from him, to see if the waters were abated from off the face of the ground; 9 but the dove found no rest for the sole of her foot, and she returned unto him to the ark; for the waters were on the face of the whole earth: and he put forth his hand, and took her, and brought her in unto him into the ark. Io And he stayed yet other seven days; and again he sent forth the dove out of the ark; I I and the dove came in to him at eventide; and, lo, in her mouth an olive-leaf plucked off: so Noah knew that the waters were abated from off the earth. 12 And he stayed yet other seven days, and sent forth the dove; and she returned not again to him any more.

"I 3 And it came to pass in the six hundred and first year, in the first month, the first day of the month, the waters were dried up from off the earth: and Noah removed the covering of the ark, and looked, and behold, the face of the ground was dried. It And in the second month, on the seven and twentietil day of the month, was the earth dry. I 5 And God spake unto Noah, saying, 16 Go forth from the ark, thou, and thy wife, and thy sons, and thy sons' wives with thee. I7 Bring forth with thee every living thing that is with thee of all flesh, both birds, and cattle, and every creeping thing that creepeth upon the earth; that they may breed abundantly in the earth, and be fruitful, and multiply upon the earth. is And Noah went forth, and his sons, and his wife, and his sons' wives with him: 19 every beast, every creeping thing, and every bird, whatsoever moveth upon the earth, after their families, went forth out of the ark.

" 20 And Noah builded an altar unto Jehovah, ard took of every clean beast, and of every clean bird, and offered burntofferings on the altar. 2 I And Jehovah smelled the sweet savor; and Jehovah said in his heart, I will not again curse the ground any more for man's sake, for that the imagination 


\section{CUNEIFORM ACCOUNT-CONTINUED.}

[rio] The tilled land was become ike the waste.

[III] I opened the window, and daylight fell upon my cheeks;

[I12] Crouching I sit (and) weep;

[II3] Over my cheeks course my tears.

[IIt] I looked at the quarters (of heaven), the borders ct the sea;

[115] Toward the twelfth point rose the land.

[116] To the country of Nizir the ship made way;

[II7] The mountain of the country of Nizir caught the ship, and suffered it not to stir.

[118] One day, a secend day, the mountain of Nizir, etc. (as before) ;

[rig] A third day, a fnurth das, the mountail of Nizir, etc (as before);

[120] A fifth, a sixth, the mountain of Nizir, etc. (as be. fore).

[I2I] But, when the seventh day was come,

[122] I brought out a dove (and) let it go.

[123] The dove went to and fro, but

[124] Found no foothold (lit. standing-place), and returned

[125] Then I brought out a swallow (and) let it go.

[iz6] The swallow went to and fro, but

[127] Found no foothold, and returned.

[128] Then I brought ouc a raven (and) let it go:

[129] The raven went off, noticed the drying of the water. and

[130] Feeding, wading, croaking, returned not.

[I3I] Then I brought out (e:eything) to the four winds: offered victims,

[132] Made an offering of incen:e an the mountain top;

[133] Seven and :even tripods I set,

[13t] Into their bowls I poured calamus, cedar, fragran! herbs; 


\section{bielicar acCOUnT-CUNTINUED.}

of man's heart is evil from his youth; neither will I again smite any more everything living, as I have done. 22 While the earth remaineth, seedtime and harvest, and cold and heat, and summer and winter, and day and night shall rot cease.

"IX. And God blessed Noah and his sons, and said unto them, Be fruitful, and multiply, and replenish the earth. 2 And the fear of you and the dread of you shall be upon every beast of the earth, and upon every bird of the heavens; with all wherewith the ground teemeth, and all the fishes of the sea, into your hand are they delivered. 3 Every moving thing that liveth shall be food for you; as the green herb have I given you all. 4 But flesh with the life thereof, which is the blood thereof, shall ye not eat. 5 And surely your blood, the blood of your lives, will I require; at the hand of every beast will I require it: and at the hand of man, even at the hand of every man's brother, will I require the life of man. 6 Whoso sheddeth man's blood, by man shall his blood be shed: for in the image of God made he man. 7 And you, be ye fruitful, and multiply; bring forth abundantly in the earth, and multiply therein.

" 8 And God spake unto Noah, and to his sons with him, saying, 9 And I, behold, I establish my covenant with you, and with your seed after you; ro and with every living creature that is with you, the birds, the cattle, and every beast of the earth with you; of all that go out of the ark, even every beast of the earth. II And I will establish my covenant with you; neither shall all flesh be cut off any more by the waters of the flood; neither shall there any more be a flood to destroy the earth. 12 And God said, This is the token of the covenant which I make between me and you and every living creature that is with you, for perpetual generations: r $_{3}$ I do set $m y$ bow in the cloud, and it shall be for a token of a covenant between me and the earth. It And it shall come to pass, when I bring a cloud over the earth, that the bow 


\section{CUNEIFORM ACCOUNT-CONTINUED.}

[135] The gods snuffed the odour,

[136] The gods snuffed the pleasant cdour,

[137] The gods like flies swarmed aboie the sacrificer.

[138] But when Ishtar was come from afar,

[139] She lifted up the Great Gems (?), which Anu had made to adorn her.

[140] 'These gods' (she cried), 'by mine azure collar (lit. by the lapis lazuli of my neck), I will never forget !

[r4r] These days will I bear in mind, and nevermore forget!

[ $\mathrm{I}+2]$ Let the gods go to the incense-offering!

[ $\mathrm{I}+3]$ (But) let Bel never go to the incense-offering!

[I+t] Forasmuch as he took no counsel, but caused the flor..

[145] And delivered my people to destruction.'

[146] But when Bel was come from afàr,

[r+7] He saw the ship, and Bel waxed wrathful;

[ $\left.\mathrm{r}_{4} 8\right] \mathrm{He}$ was filled with rage at the gods, (and) the Ig: (i.e. the spirits of heaven):

[149] 'Come soul' (he cried) 'hath escaped!

[ 150$]$ Let not a man survive the destruction!'

[15I] Ninib frameth his mouth and speaketh-

[152] He saith to the warrior Bel:

[153] 'Who then but Ia doeth the thing?

[ $15+]$ Ia is versed in every wile.'

[155] Ia frameth his mouth and speaketh-

[156] He saith to the warrior Bel:

[157] 'Thou, O sage of the gods (and) warrior-

[158] In nowise hast thou been well-counselled in causir. a flood!

[159] On the sinner lay his $\operatorname{sin!}$

[160] On the guilty lay his guilt!

[16r] (But) remit (somewhat)! let him not be cut off: iur. bear! let him not [be swept away]!

[162] Instead of thy causing a flocd, 
BIBLICAL ACCOUNT-CONCLUDED.

shall be seen in the cloud, $\mathrm{I}_{5}$ and I will remember my covenant, which is between me and you and every living creature of all flesh; and the waters shall no more become a flood to destroy all flesh. 16 And the bow shall be in the cloud; and I will look upon it, that I may remember the everlasting covenant between God and every living creature of all flesh that is upon the earth. 17 And God said unto Noah, This is the token of the covenant which I have established between me and all flesh that is upon the earth."

Following is the account by Berosus, a Chaldean priest who lived in the time of Alexander the Great and his immediate successors:-

"After the death of Ardates, his son Xisuthrus reigned I 8 sari. In his time happened a great Deluge. the history of which is thus described: The Deity, Cronos, appeared to him in a vision, and warned him that upon the 15 day of the month Daesius there would be a flood, by which mankind would be destroyed. He, therefore, enjoined him to write a history of the beginning, procedure and conclusion of all things; anu to bury it in the City of the sun at Sippara; and to build a vessel, and take with him into it his friends and relations; and to convey on board everything necessary to sustain life, together with all the different animals, both birds and quadrupeds, and trust himself fearlessly to the deep. Having asked the Deity whither he was to sail, he was answered, 'To the Gods'; upon which he offered up a prayer for the good of mankind. He 
CUNEIFORM ACCOUNT-CONCLUDED.

[163] Let the lion come and minish mankind!

[164] Instead of thy causing a flood,

[165] Let the Leopard come and minish mankind!

[x66] Instead of thy causing a flood,

[I67] Let famine break out and [desolate] the land.

[ $\mathrm{x} 68]$ Instead of thy causing a flood,

[r69] Let pestilence (lit. Girra; i.e. the god of plague) come and slay mankind!

[170] I divulged not the decision of the mighty gods;

[r7I] (Someone) caused Atranasis to see visions, and so he heard the decision of the gods.'

[172] Thereupon he took counsel with himself (or made up his mind);

[173] Bel came on board the ship,

[r74] Seized my hand and led me up (out of the ship),

[175] Let up my wife (and) made her kneel beside me;

[176] He turned us face to face, and standing between us blessed us, (saying):

[177] 'Ere this, Nûh-napishtim and his wife shall be like us

$\left[{ }^{1} 78\right]$ But now Nûh-napishtim and his wife shall be like us gods!

[179] Nûh-napishtim shall dwell far away (from men), at the mouth of the rivers!'

[r8o] Then they took me, and made me dwell far away, at the mouth of the rivers." 
then obeyed the Divine admonition, and built a vessel five stadia in length and two in breadth. Into this he put everything which he had prepared: and last of all conveyed into it his wife, his children and his friends.

"After the Flood had been upon the earth, and was in time abated, $\mathrm{X}$ isuthrus sent out birds from the vessel, which, not finding any food nor any place whereupon they might rest their feet, returned to him again. After an interval of some days he sent them forth a second time, and they now returned with their feet tinged with mud. He made a trial a third time with these birds. but they returned to him no more: from whence he judged that the surface of the earth had appeared above the waters. He, therefore, made an opening in the vessel, and upon looking out found that it was stranded upon the side of some mountain, upon which he immediately quitted it with his wife, his daughter and the pilot. Xisuthrus then paid his adoration to the earth and, having constructed an altar, offered sacrifice to the gods, and, with those who had come out of the vessel with him, disappeared.

"They, who remained within, finding that their companions did not return, quitted the vessel with many lamentations, and called continually on the name of $X$ isuthrus. Him they saw no more; but they could distinguish his voice in the air, and could hear him admonish them to pay due regard to religion; and likewise informed them that it was upon account of his piety that he was transiated to live with the gods, that his 
wife and daughter and the pilot had obtained the same honor. To this he added that they should return to Babylonia, and, as it was ordained, search for the writings at Sippara, which they were to make known to all mankind; moreover, that the place wherein they then were was the land of Armenia.

"The rest having heard these words, offered sacrifices to the gods, and, taling circuit, journeyed toward Babylonia.

"The vessel being thus stranded in Armenia, some part of it yet remains in the Corcyraean mountains."

By way of comparison, it is instructive to notice:-

I. That the cuneiform inscription is from start to finish polytheistic (lines 3-17), whereas the narrative in Genesis is monotheistic.

2. The cuneiform agrees with the biblical narrative in making the Deluge a divine punishment for the wickedness of the world (lines 5, 6).

3. The names differ to a degree that is irreconcilable with our present knowledge.

4. The dimensions of the ark as given in Genesis (vi. I5) are reasonable, while those of Berosus and the cuneiform tablets are unreasonable. According to Genesis, the ark was 300 cubits ( $562 \mathrm{I}-2$ feet) long, 50 cubits (93 $2-3$ feet) wide, and 30 cubits $\left(\begin{array}{lll}56 & \mathrm{I}-4\end{array}\right)$ deep, which are the natural proportions for a ship of that size, being in fact very close to those of the great 
steamers which are now constructed to cross the At lantic. ${ }^{2}$ The Celtic of the White Star line, built in I9OI, is 700 feet long, 75 feet wide, and 49 I-3 feet deep. The dimensions of the Great Eastern, built $i:$ i 858 (692 feet long, 83 feet broad, and 58 feet deep), are still closer to those of the ark. The cuneiform tablets represent the length, width, and depth each as $\mathrm{I}$ fO cubits (262 feet), (lines 22, 23, 38-41), the dimensions of an entirely unseaworthy structure. According to Berosus, it was five stadia (3,000 feet) and two stadia ( 1,200 feet) broad; while Origen represented it to be 135 ,000 feet (25 miles) long, and 3,750 feet (3-t mile) wide. ${ }^{3}$

5. In the biblical account, nothing is introduced conflicting with the sublime conception of holiness and the peculiar combination of justice and mercy ascribed to God throughout the Bible, and illustrated in the general scheme of providential government manifest in the order of nature and in history; while, in the cuneiform tablets, the Deluge is occasioned by a quarrel among the gods, and the few survivors escape, not by reason of a merciful plan, but by a mistake which aroused the anger of $\mathrm{Bel}$ (lines 146-150).

6. In all the accounts, the ark is represented as floating up stream. According to Genesis, it was not, as is usually translated, on "Mount Ararat" (viii. 4), 
but in the "mountains of Ararat," designating an indefinite region in Armenia upon which the ark rested; according to the inscriptions, it was in Nizir (lines I I 5-I2O), a region, in close proximity to Ararat, which is watered by the Zab and the Tornadus; while, according to Berosus, it was on the Corcyraean Mountains, included in the same indefinite area. In all three cases, its resting-place is in the direction of the headwaters of the Euphrates Valley, while the scene of the building is clearly laid in the lower part of the valley.

7. Again, in the biblical narrative, the spread of the water floating the ark is represented to have been occasioned, not so much by the rain which fell, as by the breaking-up of "all the fountains of the great deep" (vii. II), which very naturally describes phenomena connected with one of the extensive downward movements of the earth's crust with which geology has made us familiar. The sinking of the land below the level of the ocean is equivalent, in its effects, to the rising of the water above it, and is accurately expressed by the phrases uses in the sacred narrative. This appears, not only in the language concerning the breakingup of the great deep which describes the coming-on of the Flood, but also in the description of its termination, in which it is said, that the "fountains of the deep .... were stopped, . . and the waters returned 
from off the earth continually (viii. 2, 3). Nothing is said of this in the other accounts.

- 8. The cuneiform tablets agree in general with the two other accounts respecting the collecting of the animals for preservation, but differ from Genesis in not mentioning the sevens of clean animals and in including others beside the family of the builder (lines 66-69).

9. The cuneiform inscription is peculiar in providing the structure with a mast, and putting it in charge of a pilot (lines $45,70,7 \mathrm{I})$.

IO. The accounts differ decidedly in the duration of the Flood. According to the ordinary interpretation of the biblical account, the Deluge continued a year and seventeen days; whereas, according to the cuneiform tablets, it lasted only fourteen days (lines I03IO7, I I 7-122).

11. All accounts agree in sending out birds; but, according to Genesis (viii. 7), a raven was first sent out, and then in succession two doves (viii. 7-12); while the cuneiform inscription mentions the dove and the raven in reverse order from Genesis, and adts a swallow (lines I 2 I-I 30 ).

12. All accounts agree in the building of an altar and offering a sacrifice after leaving the ark. But the cuneiform inscription is overlain with a polytheistic 
coloring: "The gods like flies swarmed about the sacrifices" (lines 132-143).

13. According to the biblical account, Noah survived the Flood for a long time; whereas Nûh-napishtim and his wife were at once deified and taken to heaven (lines $177-180$ ).

14. Both accounts agree in saying that the human race is not again to be destroyed by a flood (Gen. ix. I I ; lines I62-169).

Close inspection of these peculiarities makes it evi. dent that the narrative in Genesis carries upon its face an appearance of reality which is not found in the other accounts. It is scarcely possible that the reasonable dimensions of the ark, its floating up stream, and the references to the breaking-up of the fountains of the great deep should have been hit upon by accident. It is in the highest degree improbable that correct statements of such unobvious facts should be due to the accident of legendary guesswork. At the same time, the duration of the Deluge, according to Genesis, affords opportunity for a gradual progress of events which best accords with scientific conceptions of geological movements. If, as the most probable interpretatior would imply, the water began to recede after one hundred and fifty days from the beginning of the Flood, and fell fifteen cubits in seventy-four days, that would 
be only three and two-thirds inches per day, - a rate which would be imperceptible to an ordinary observer.

Many years ago, a friend who had given very careful attention to all the details of the narrative, arrived at the conclusion that the basis of the biblical account is the log-book that was kept on the ark. His presentation of the case is scientific and convincing. We are happy to be permitted to transmit it in full. ${ }^{4}$

"The record says that Noah entered the ark the seventeenth day of the second month, and that it began at once to rain, and rained forty days, and then ceased, on the twenty-seventh day of the third month. Before it stopped, the record gives these particulars: ( I) the ark soon began to float; (2) the ark went floating on the waters driven by strong winds; (3) it touched bottom on the top of what later seemed to be the highest mountain in sight, on the seventeenth day of the seventh month.

"If they had touched land somewhere and sailed from it, they could have had no assurance that it was the top of a high mountain; but if, on that day, the ark rested and remained on the top of a mountain, which, when they looked out later, seemed as high as any in sight, they would naturally say, 'The water was fifteen cubits above the mountains.' It would have been absurd for any later writer to pretend to tell just how deep the water was over the mountain top, unless from a record made there. There seems no other way for 
any one to have known except as suggested, unless by direct revelation. It seems as though Gen. viii. 4 belongs right after vii. $2 \mathrm{O}$, or that it should be translated, 'The ark had rested. ...'

"We are then told that the waters prevailed one hundred and fifty days, and then began to go down. When do these one hundred and fifty days begin? At the beginning or the end of the forty days of rain? It is not certain. But the writer seems to teach that for forty days the waters were conquering the earth, and then completely triumphed over it for one hundred and fifty days more. Why did not the waters begin to abate soon after the rain ceased, instead of one hundred and fifty days or possibly one hundred and ten days later? To those in the ark the water seemed to keep rising three months and twenty days after it stopped raining, when they touched bottom on Ararat, and, if I read it rightly, it did not begin to abate till forty days later, and they would know at once when the water began to go down around the ark. When it did could only be known in the ark. They said that it was at the close of the one hundred and fifty days. Who could have got up such a legend years after?

"But look again at our log-book (vii. I I), where the writer says not only that it rained, but that the fountains of the great deep were broken up. Evidently it seemed to him in the ark that not only the rain poured down, but that the sea came rushing in upon them, and he does not say till viii. : , that the fountains of the 
deep were stopped. Evidently it seemed to him that the incoming and outgoing deeps had more to do with the flood than the rain. If there had been no sinking and rising of the land to produce this phenomenon, it is absurd to suppose that the flood would not have begun to subside sooner than one hundred and fifty or even one hundred and ten days after the forty days of rain. But in the ark they would naturally record the exact date they felt the water beginning, to lower around them.

"Thirty-four days after the waters le.gan to settle (seventy-four, if we count the one hurdred and fifty from the beginning of the flood), on the first day of the tenth month. Noah records that the up of this mountain is above the water. The ark stinds on dry land. It must have brought a joy never to be forgotten. Surely they would give the exact date thereof. So the water has settled just fifteen cubits. Forty days later, on the eleventh day of the eleventh morith, he sent out a raven, and it returned not. On the eighteenth he sent out a dove, but it hastened back. On the twentyfifth he sent it out again, and it brought back a freshpicked olive leaf. On the second of the twelfth month he sent it out again, and it returned no more. Twentynine days later, on the first day of the year, perhaps his birthday, he for the first time removed the covering of the ark, and, looking in every direction, could see no body of water. How natural to take such a look and make such a record on that day! Quietly he waited 
fifty-six days more. Then God, who had shut him in one year before, and had been there with him, opened the door, and said, 'Go forth.'

"NOAH'S LOG-BOOK.

NUMBER

" MONTH DAY

OF DAYS

$2 \quad 17$ All enter the ark, God shuts the door.

Rains fall. Floods pour in from sea to Ark floats.

Ark sails swiftly.

327 Rain stops.

Floods keep pouring in and water

rising

$7 \quad$ I 7 Ark touches bottom on top of high mountain and stays there. Waters stop rising.

Water stationary

827 Waters begin to settle.

Settle fifteen cubits in

ro I Ark left on dry land.

Waters continue to settle. Noah waits

I Noah sends out a raven. It returns not.

Waters settle, Noah waits

Toah sends out a dove. It returns.

Waters settle, Noah waits

I 25 Noah sends out dove again. Dove brings an olive leaf just grown. Waters settle, Noah waits

I 2

2 Noah sends out dove again. It returns not.

Waters settle, Noah waits

I i Noah removes covering, looks all a round. 
No water can be seen.

Ground dries up. Noah waits forth.'

Total time of flood

EXTENT OF THE DELUGE.

We are not, however, compelled to narrow the interpretation of the biblical account down to the level of a hard-and-fast prosaic statement of dry detail. This whole episode in the history of the human race was introduced for the accomplishment of a moral purpose, which is enforced in the story by literary forms calculated to make the required impression, without pausing to gratify curiosity respecting all incidental details. The narrative portions are extremely condensed, apparently limiting themselves, as the log-book of a seacaptain would do, to the most clearly marked objective facts of observation, without effort to harmonize them either with themselves or with any comprehensive view of the universe. The expressed object of the Flood may therefore properly be permitted to limit the meaning of many of the general phrases introduced into the vivid account. This is so plain a principle of interpretation that it would seem to need for its substantiation little more than the bare statement. But, as many extremists 
on both sides fail to appreciate the principle, a few words may profitably be devoted to its illustration.

Long before the rise of geology and of the doubts which it has raised concerning the contemporaneous universality of the Flood, it was noted by various learned commentators that the biblical account of the Deluge bore evidence that it was written by an eye-witness, and hence should be interpreted according to the natural limitations of such writing. In documents thus prepared, synecdoche has a preëminent place. The language describes what appears to the senses, and does not go beyond the phenomena which are visible. It does not try to settle minute extraneous questions. Nothing is more common than this figure of speech, where the part is put for the whole, and the horizon which limits our vision is spoken of as the horizon of the whole world. It falls to the lot of scientific interpreters to determine the extent to which this figure of speech legitimately modifies the literal interpretation of the text.

All the universality required by the language dcscribing the Noachian Deluge would seem to be that which is necessary for the accomplishment of its ostensible purpose, namely, such a destruction of the human race that history could begin over again under new conditions of heredity and environment. Some of the general phrases used, therefore, may properly be 
defined by the expressed object of the Divine judgment, while others have a natural boundary in the horizon which limits the writer's knowledge or observation. The objects of the Flood are all satisfied if the destruction of the human race with the exception of Noah's family was fully accomplished. ${ }^{5}$

Respecting this point, it will be shown later, that it would be difficult to prove that, at the time of the Flood, the surviving members of the human race were not limited to a narrow area somewhere in the valley of the Euphrates. For example, Hugh Miller and others have plausibly urged that the human race before the Deluge had not spread very far from its original center, and that, owing to its great wickedness, it had not multiplied so as to secure any great density of population even there. While this is possibly the case, we shall present another view, which will be supported by many recently discovered facts, pointing to a widespread destruction of antediluvian man in connection with recent great geological changes which have taken place since his appearance in the world. These considerations will prepare the way for regarding the Nonchian Deluge as a catastrophe in Central Asia closing a series which had then possibly restricted the human race to that region. In this attempt, however, we arc not called upon to prove the Flood independent of his- 
tory, but simply to remove objections to the credibility of the history raised from unwarranted scientific assumptions.

Viewing the story of Genesis as the account of a really extensive, but comparatively limited, catastrophe in Central Asia, to which the survivors of the human race were then confined, the interpretation of the general phrases used may allowably be determined by the general limitation of the field which was within the reach of the writer's mental vision. Illustrations of this principle are familiar enough. When, for example, Job describes the thunder as being "sent forth under the whole heaven, and his lightning unto the ends of the earth" (Job xxxvii. 3), we have no difficulty in understanding it as having reference simply to the whole visible horizon, for everybody uses similar expressions with this implied limitation. When we say, "Everybody knows it," or " The whole country turned out to see him," we have no difficulty in explaining that these phrases, though absolutely general in their form, are yet much restricted in their meaning.

For example, we are told in Deut. ii. 25 , that the dread and fear of Israel should that day be put " upon the nations that are under the whole heaven." But the interpreter who should insist upon the absolute literality of such a phrase would prove not the point which he in- 
tended to prove, but rather the narrowness of his own range of familiarity with literature. So when, in Gen. xli. 54 and 57 , it is said that there was a famine "in all lands," or "over all the face of the earth," and that "all countries" came to Egypt to buy corn, it would be only an interpreter of a very narrow acquaintance with literature who should insist that the language was literal, and that the irrigated plains of Babylonia were as dependent upon Egypt as were the hills of Judæa. So, also, when the writer of the book of Kings says that Solomon exceeded all the kings of the earth for riches, and that all the earth sought to hear his wisdom; and when the Saviour says that the Queen of Sheba came "from the uttermost parts of the earth," he would be a very narrow and ill-informed interpreter who should insist upon the strict literality of the words. In Acts ii. 25, we are told that there were present in Jerusalem on the day of Pentecost people "out of every nation under heaven," but when the enumeration is made it includes only the region extending from Italy to the Persian Gulf, over which the Jews are known to have spread. When Cresar is said to have taxed "all the world," and we say that it means all the Roman Empire, we should not be construed to assert that the writer supposed there were no outlying provinces yet unsubdued by the Roman power. 
And so, when Paul (in 58 A.D.) asserts that the faith of the church at Rome was already " spoken of throughout the whole cosmos," it would be supremely puerile to insist upon the bare literal interpretation of the words.

In accordance with this principle of interpretation, we are permitted to regard the universal statements concerning the Flood as being the language of appearance such as would present itself to eye-witnesses of the catastrophe, and limited in its general results to the main purpose for which it came. So that "all the mountains and hills under the whole heavens" may naturally mean all those within the horizon of the writer's vision, or within reach of his knowledge, or within the circle which was then inhabited by man. ${ }^{6}$

THE DATE OF THE FLOOD.

Before entering upon the direct presentation of the facts bearing upon the question in hand, it will be best to prepare the way for answering one other objection, which may arise on the score of chronology. The present discussion will proceed upon the assumption that the date of the Flood may be placed considerably earlier than that given by the ordinary chronology as worked out by Archbishop Usher, or, indeed, as it would be obtained by considering merely the prima facie evidence 
in the first chapters of Genesis. But a careful study of the subject will show that the genealogical tables in the fifth and eleventh chapters are not designed to give chronological data, but merely to indicate lines of descent. The character of these tables has been so fully discussed by the late Professor William Henry Green, that we may content ourselves with a brief summary of his arguments, referring to the elaborate article itself for the fuller substantiation of the conclusions arrived at. ${ }^{7}$

In the genealogies in the fifth chapter of Genesis, ten generations are mentioned between Adam and Noah, and the age of the parent at the time of the birth of the son who is next in the chain is in each case given; while in the eleventh chapter ten more generations between Noah and Abraham are mentioned in the same manner; - that is, the age of the parent at the birth of each successive son is given in definite fig. ures; so that, by adding together these sums to the date of Abraham (which is I9I 8 B.c.), as Archbishop Usher did, we get the dates which are found in the margins of many of our English Bibles, namely, of the creation of man, foot years B.c.; and of the Flood, 2348 B.c. Upon the face of it, it looks as though there could be here no way of avoiding conflict between a clear Bible statement and the result of modern investigations in 
geology and archæology, which give a much higher antiquity to man and to the civilization in Egypt and Babylonia; for these chronological data in the genealogical tables seem to be linked together in such a way that there is no lengthening the chain without altogether destroying its continuity.

Close study of the subject, however, will convince any one that even the linked.genealogical tables of these chapters were not intended by the writer, nor understood by his readers, to teach a definite chronology, but are inserted simply to show lines of descent, in which any number of intermediate links may be omitted without interfering with the purpose of the tables. This conclusion is based, not upon mere speculative reasons, or the necessity of making out a case, but upon the manifest usage of the sacred writers in numerous other places, and upon a careful consideration of the tables themselves.

As one of the most instructive examples, we may turn our attention to the first chapter of Matthew. where, in the first verse, Christ is called in the same breath "the son of David" and "the son of Abraham," after which the complete list is seemingly given in close column, extending from Abraham down. But it is noticeable that the names are divided into three groups of fourteen each. To bring them within the 
limits of these exact numbers, however, we find that three names are omitted in verse 8 . It is said that "Joram begat Ozias" (Lzziah), where we know from the book of Kings that three names have been omitted-Ahaziah, Joash, and Amaziah; while again, in verse I I, Jehoiakim is omitted after Josiah.

What now is it reasonable to conclude from these passages? Shall we say that the writer of this chapter did not know of the existence of those links which he dropped out? Certainly not, for this is the Gospel that was written by a Hebrew, and both he and his readers had ready access to, and were devoted believers in, the Old Testament, and they were surrounded by Jewish opponents who would readily find fault with any serious misuse of it. The only explanation, therefore, is that all were so familiar with the use of genealogies to indicate simply lines of descent, without any reference to chronology, that nobody thought of raising any question concerning such use. Interpreters, therefore. should learn from this passage to be on their cruard acainst making chronological use of similar tables in other portions of Jewish literature.

Turning to the Old Testament itself, we notice, among others, one of the clearest examples in I Chron. xwi. 24, where we read that "Shebucl the son of Gershom, the son of Moses, was ruler over the treasures," 
and again in I Chron. xxiii. 15,16 , we read that "the sons of Moses were Gershom and Eliezer. Of the sons of Gershom Shebuel was the chief." But Shebuel was appointed over the treasury by David four hundred years after the time of Moses; so that eight or ten generations must have intervered between Gershom and Shebuel. Still, notwithstanding this, the identical term is used twice over, in expressing the relation between Moses and Gershom, that is used in expressing that between Gershom and Shebuel. Again, in Ezra vii. I-5, the writer of this book, doubtless with full krowiedge of what was written in the Chronicles before him, gives Ezra's genealogy in the line of Aaron, but in the table skips from Meraioth to Azariah, omitting six names which appear in the parallel passage in I Chron. vi. 3-I 4 . Here, again, it would be absurd to suppose that such omissions were made through igno:ance, since they created no disturbance in the minds of the Jews in general who read them. They simply illustrate what were the familiar usages of speech among the Jews.

And so we might go on enumerating a dozen other instances in which similar free use is made of genealogical tables where it is clear that the chronological questions connected with them are not taken into account in the least. The condensation of crenealogical 
tables was with the Jews the rule, and not the exception. Manifestly they were used as we may use the phrase "sons of the Pilgrims," where everything but the line of descent is left out of view. Until, with Professor Green, one takes pains to go through the long list of genealogies abbreviated in the same manner in the Old 'Testament, he cannot have any proper conception of how frequent this use is, and how clear the point we are making appears from the facts.

In Professor Green's discussion he goes on further to show, that not only is there no difficulty in supposing that the genealogical tables in Gen. v. and xi. are abbreviated, but that there are many special reasons in the tables themselves and in the contexts in which they occur, to show that this is really the case. In the first place, a strict literal interpretation of the first genealogical table (v. 3) might naturally lead us to infer that Seth was Adam's first child. The only way in which we find out that he was not, is from the history of Cain and Abel and the mention of a wife to Cain in the preceding chapter.

Secondly, no chronology is ever deduced from these tables by the sacred writers. "There is no computation anywhere in the Scriptures of the time that elapsed from the creation or from the Deluge, as there is from the descent into Egypt to the Exodus (Ex. xii. 
40), or trom the Exodus to the building of the temple (I Kings vi. I)." At the same time, the prominence given to the length of the individual lives after the birth of the son mentioned shows that something else than chronology was what the writer wished to impress upon the reader.

Thirdly, in the convincing words of Professor Green,-

"The structure of the genealogies in Gen. v. and xi. also favors the belief that they do not register all the names in these respective lines of descent. Their regularity seems to indicate intentional arrangement. Each genealogy includes ten names, Noah being the tenth from Adam, and Terah the tenth from Noah. And each ends with a father having three sons, as is likewise the case with the Cainite genealogy (iv. I722). The Sethite genealogy (chap. v.) culminates in its seventh member, Enoch, who "walked with God, and he was not, for God took him.' The Cainite genealogy also culminates in its seventh member, Lamech, with his polygamy, bloody revenge, and boastful arrogance. The genealogy descending from Shem divides evenly at its fifth member, Peleg; ' and in his days was the earth divided.' Now as the adjustment of the genealogy in Matthew i. into three periods of fourteen generations each, is brought abcut by dropping the requisite number of names, it seems in the highest degree probable that the symmetry of these primitive genealogies 
is artificial rather than natural. It is much more likely that this definite number of names fitting into a regular scheme has been selected as sufficiently representing the periods to which they belong, than that all these striking numerical coincidences should have happened to occur in these successive instances."

"The notion of basing a chronological computation upon these genealogies is, therefore, a fundamental mistake. It is putting them to a purpose that they were not designed to subserve, and to which from the method of their construction they were not adapted. But, when it is said, for example, that 'Enosh lived ninety years and begat Kenan,' the well-established usage of the word 'begat' makes his statement equally true and equally accordant with analogy, whether Kenan was an immediate or remote descendant of Enosh; whether Kenan was himself born, when Enosh was ninety years of age, or one was born from whom Kenan sprang."

In other words, Kenan may simply have been a remote descendant of the branch which put off from the line of Enosh in the ninetieth year.

"We conclude, therefore [says Professor Green], that the Scriptures furnish no data for a chronological computation prior to the life of Abraham; and that the Mosaic records do not fix and were not intended to fix the precise date either of the Flood or of the creation of the world."

"If, therefore [he goes on to say], any really trustworthy data can be gathered from any source whatever, 
which can be brought into comparison with these genealogies for the sake of determining the question, whether they have noted every link in the chain of descent, or whether, as in other manifest instances, links have been omitted, such data should be welcomed and the comparison fearlessly made. Science would simply perform the office, in this instance, which information gathered from other parts of Scripture is unhesitatingly allowed to do in regard to those genealogies previously examined."

Whereupon he proceeds to give reasons, from archx. ology and from the narrative in Genesis itself, going to show that the Flood was much earlier than would appear from the chronology ordinarily obtained from the scriptural language.

After this much of attention to preliminary questions relating to the proper understanding of the biblical account, we will turn, in following chapters, to consider the vast amount of evidence which has recently come to light showing ( $I$ ) that there has been a period of instability of the earth's crust extending down to comparatively recent times, which, from a scientific point of view, renders the scriptural account of the Flood easily credible; (2) that some such wide-spread catastrophe has actually occurred since the advent of man. 


\section{SCIENTIFIC CREDIBILITY OF THE DELUGE.}

The main evidence of the Noachian Deluge must always be historical; but it is the prerogative of science to consider the intrinsic credibility of the event, and so to remove unwarranted prejudicial bias. With this in view, we will limit ourselves, in the present chapter, to facts bearing upon the reasonable credibility of the supposition, that, since man came into the world, there may have been changes of land-level of sufficient extent and rapidity to destroy the human race, and fairly to meet the demands of the biblical narrative when properly interpreted. The adequate discussion of this point calls for a somewhat comprehensive survey of geological theories relating to the general stability of land-levels, and of the causes of the extensive changes of level which all admit to have taken place. The first of these has to do with the general question of uniformity in the action of geological forces. It will be in place, therefore, at the outset, to adduce the considerations which emphasize the fact that the stability of the earth's crust is by no means a constant quantity throughout all time. 


\section{GEOLOGICAL FORCES ARE FAR FROM UNIFORM IN THEIR ACTIVITY.}

Geologists may be roughly divided into three classes, -Catastrophists, Uniformitarians, and Evolutionists. The Catastrophists hold that nearly all the changes in the earth's surface have taken place with great rapidity. In their view, the species which succeed each other in the geological strata were, each and all, fresh creations. At each geological epoch, according to the Catastrophists, the board was swept clean, and a new record spread upon its surface. The mountains were upheaved by a single stroke of divine power, and the foundations of the great deep were broken up with equal suddenness. A hundred years ago the Catastrophists held the field against all opponents. Indeed, their theories were scarcely questioned by anybody.

But, largely through the influence of Sir Charles Lyell, in the publication of his "Principles of Geology" in 1830 , the Catastrophists were in due time almost entirely superseded by the Uniformitarians. These hold that the present is a perfect measure of the past,- - that all the vast geological changes to which the earth's crust bears witness, were effected by the slow processes which are now going on. With this view, the Uniformitarians felt free, and were indeed compelled, to make unlimited drafts upon the bank of time, and allot hun- 
200 Scientific Credibility of the Deluge.

dreds of millions of years to a single geological period, as though eternity alone limited the history of the earth's changes. In one of Darwin's famous calculations, $306,662,400$ years is spoken of as "a mere trifle" of geologic time. ${ }^{1}$

The difference between these two theories has bee? well set forth in the saying, that " the Catastrophists are prodigal of force, and parsimonious of time; while the Uniformitarians are parsimonious of force, and prodigal of time." Indeed, the leading Uniformitarians were so parsimonious of force that they were aptly characterized as "the homocopathic school of dynamics."

The more attentive study of the facts, and the more rational attitude of mind, which characterize the opening of the twentieth century, are bringing into prominence the great truth which lies between these two extremes. In the light of these, it is seen that the processes of nature cannot be comprehended under either of the foregoing theories. There is, in fact, no such thing as uniformity in nature. On the contrary, nature is a continuous series of changes the rate of which is far from uniform. Sometimes these changes proceed for a long period at a rate so slow that its steps seem almost infinitesimal, while at other times they go forward with leaps and bounds. The true theory is that of Evolution. There is continuity in the geolog- 
ical progression, but not uniformity: catastrophes are by no means unknown in nature. ${ }^{2}$

The illustrations of this principle are so numerous and familiar that it seems strange that it should ever have been overlooked. In every great movement, there is a last straw which "breaks the camel's back" and produces visible results which are out of all proportion to what had before been apparent. The boiler remains intact under increasing steam pressure up to a certain point, before which the successive addition of pound after pound of pressure produces no apparent change in the phenomena; but, upon the addition of another pound's pressure, it bursts into a thousand fragments, and shatters everything with which it comes in contact. Or, again, the bow gradually bends to every successive increase in the strain to which it is subjected up to a certain point, when it suddenly snaps in the archer's hands, and becomes a useless piece of wood. In either case, mathematicians might have predicted the results, if the nature of the forces involved had been fully known. But empirical philosophy which made the past and the observed narrow present a full measure of the future, would have been completely at fault in its predictions.

Turning to greater things for illustration, we may note that, previous to the first century of our era, the 
fires of Vesuvius had been so long quiescent that all memory of their former activity had been erased from the consciousness of mankind. The slopes of the extinct crater were covered with vineyards and villas. The cities of Pompeii and Herculaneum were thronged with a pleasure-seeking crowd, all of whom were "Uniformitarians," believing that "from the beginning of the world all things had remained as they were," and that the present was a full measure of the future. But, in the year 63, suddenly this feeling of security was shocked by an earthquake which shook down palatial residences and prostrated defensive walls which from time immemorial had been the pride of Southern Italy. In the twinkling of an eye, the pressure of the accumulating gases beneath had passed the danger-point, and produced a catastrophe of the most tragic order.

But even this was not sufficient to disturb the false security. Roman capital and Roman artists poured into the desolated city, and in a decade rebuilt it on a scale of still more magnificent splendor. In freshly adorned palaces the philosopher retired to the quiet of these unrivaled pleasure-resorts, to ponder upon themes which were out of place amid the every-day affairs of the great capital on the Tiber; while the satirical poet built his luxurious residence close by, from which to 
launch his keen shafts of ridicule; and the courtesan, in a neighboring street, shamelessly flaunted the sign of her nefarious enticements. Thu; iiterally, a whole city full of pleasure-seekers was ciancing on the edge of a volcano.

The end was such as to make an impression which few occurrences in history have done. This time the struggling vapors beneath found relief, not in an earthquake, but in dense showers of volcanic dust and in streams of lava. Herculaneum was hermetically sealed by a broad sheet of basalt. Pompeii was buried beneath showers of dust and ashes. Moistened by the copious rain which accompanied the eruption, the fine sediment flowed into the parlors and bedrooms and workshops and prison-cells, and inclosed the inmates, making casts of them in all the lifelike attitudes in which they were found. Thus, for more than a thousand years, these cities lay hid from view, while the gardens and vineyards of successive generations flourished on the rich soil above the houses of Pompeii, and chariots rumbled unceasingly on the natural pavement made by the incasing sheet of lava which covered the streets of Herculaneum. During much of this period. Vesuvius was quiescent, and, for a while, Spartacus, with his band of robbers, found a ready-made natural fortress in the crater of this historic volcano. 
204 Seientific Credibility of the Deluge.

More recently, the tragic events in Martinique and California and Chili have emphasized the same great truth. To be a "Uniformitarian" in presence of such facts requires a peculiar definition of uniformity.

But to measure the small demands made on our credulity by the story of the Flood, we do well to consider attentively the fact that

\section{ALL GeOlOGICAL MOVEMENTS ARE COMPARA-} TIVELY SLIGHT.

It is almost impossible not to have an exaggerated idea of the relative greatness of the changes of level in the earth's surface which are brought to light by geologic investigation. When we read of the actual changes of level which have taken place since the beginning of the Tertiary period, for example, they seem enormous. Nearly all the high mountains of the world are the result of that period of land elevation. The Pyrenees, the Alps, the Himalayas, the Andes, and the Rocky Mountains, all bear upon their summits deposits of sea-shells belonging to this most recent geological epoch. Since the middle of the Tertiary period, all these mountains have been raised to their present heights from the level of the sea. Here is brought to view an elevation of land more than two miles in vertical extent. Nor was the elevation confined to the 
narrow mountain-chains. The vast plateaus of Central Asia shared in the movement; while the extensive western plains of the United States from the Mississipi River to the Pacific Ocean then received most of their elevation. There is abundant evidence, also, that Northeastern America and Northwestern Europe, at the close of that period, stood from two thousand to three thousand feet higher than they do now. Furthermore, this elevation at the close of the Tertiary period, which was coincident with the coming-on of the Glacial epoch, soon gave place to a subsidence which car. ried the land much below its present level. At the close of the Glacial epoch, the land at Montreal was six hundred feet lower than it is now, and farther north one thousand feet lower. Deserted post-glacial seabeaches abound in the Scandinavian peninsula up to one thousand feet above present sea-level. ${ }^{3}$

But great as these changes of level in the earth's crust have actually been, they are relatively very small; so that one may well wonder how the delicate equilibrium between land and sea which is essential to civilization, and indeed to life, is secured. The earth is a sphere eight thousand miles in diameter. A mountain-chain four miles high produces only a roughness on the surface one-two-thousandth part of this; while, in the vicinity of Denver, the plateau, which there reaches the 
elevation of about a mile, produces a swelling of the circumference amounting to only one-eight-thousandth of the diameter. Were we to transfer these inequalities to a globe ten feet in diameter,-an object, by the way, which would leave little space in a moderate-sized sitting-room, - the roughness of the surface would be hardly appreciable: the plains of Denver would be represented by a bulging in the surface of only about one-sixty-sixth of an inch, or the thickness of a moderately thin sheet of paper; while, if these irregularities were represented to scale on a globe the size of a large apple, they would become indiscernible, except with a microscope. The desiccation of an apple does not have to go far to produce wrinkles of that size. The irregularities on the earth's surface do not indicate any greater relative changes than this in its interior, or any relatively greater exertion of the forces stored within it.

In cheap derision of the biblical Deluge, we often hear it said, that there is not water enough in existence to cover the tops of the highest mountains. This flippant remark overlooks the fact that the biblical account, as already remarked, represents the Flood as caused not so much by the rising of the water, as by the sinking of the land. It says that all the fountains of the great deep were broken up. Now, if all the land in the world should sink below the level of the sea, it would raise 
the water-level only a few hundred feet; whereas, the tide regularly rises seventy feet in the Bay of Fundy. The abstraction of the water from the ocean during the Glacial epoch to be locked up in ice over the northern hemisphere, and its subsequent return on the melting of the ice at the close of the epoch, produced changes in the ocean level half as great as Noah's flood would have done, on the most literal interpretation of the account.

That we may not overestimate the significance of the present relative stability of the earth's crust, it is in place to consider more in detail the known extent of

SOME RECENT GREAT GEOLOGICAL CHANGES.

Fortunately, the balance of geological forces is so delicate and perfect that most of the changes on the earth's surface take place slowly. Otherwise it would have been impossible for the higher forms of life to have maintained their existence. But there are many facts which bear indubitable witness to recent geological movements of great relative rapidity. Among these may be enumerated many lake basins occupying depressions in the earth's surface. Of them we will for the present speak of only three which have recently come under personal observation, namely, Lake Baikal, and the Aral and Dead seas. 
Lake Baikal occupies a north-and-south cleft in the broad belt of elevated table-land which extends from Central Asia into Northeastern Siberia. It is about

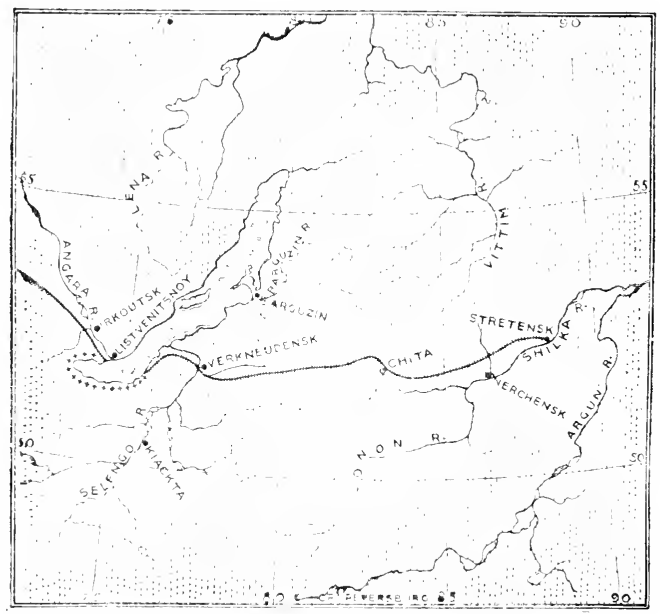

Map of Lake Baikal.

four hundred miles long and thirty wide. Its elevation is $1,56 \mathrm{I}$ feet above the sea, but the mountains on either side rise to a height of from four thousand to seven thousand fect. The mountain barrier on the west, however, is narrow, and penetrated by a single transverse cleft, through which the Angara River carries the surplus water of the vast drainage basin emptying into 
the lake. But, unlike the other rivers mentioned, this has by no means kept pace in erosion with the elevation if the barrier. It still has much to do before it obliter-

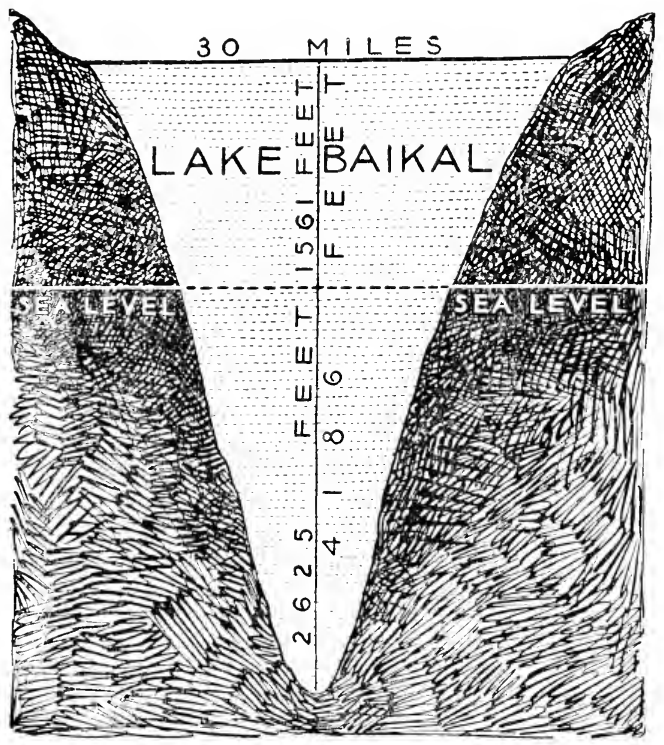

Cross Section Showing the Depth of the Southern Part of the Lake.

ates the rapids which separate the lake from the more leisurely current of the river fifty miles below, at Irkutsk.

Still further, the present depth of the lake is signifi- 


\section{Scientific Credivility of the Deluge.}

cant. While the northern portion is shallow, being only a few hundred feet deep, the southern portion runs down to a depth of 4,180 feet, or nearly three thousand feet below sea-level. The significance of these facts is enhanced by those relating to its drainage basin. This covers an area of about two hundred thousand square miles, and is served by the Selenga, the Khilok, the Uda, and the Upper Angara (rivers of the first order), besides numerous smaller streams. These all come down from the surrounding high granitic table-lands with a gradient which makes their erosive nower excessively large. And they are all characterized by open croded channels from one mile to several miles broad, with a depth of one or two thousand feet. Evidently the amount of sediment brought down has been enormous,-enough to have filled the bed of the lake many times over. The most of this sediment was formerly carried past the area now occupied by Lake Baikal, and, consolidated into rock, forms the extensive plains and the mountain border surrounding the city of Irkutsk. The great depth of the lake, therefore, and indeed its existence at all, indicates that the subsidence of its bottom is an event of recent geological occurrence.

Its recentness may be appreciated by the following brief calculation: The Selenga River, emptying into Lake Baikal from the east about one hundred miles 
from the south end, drains, as we have said, an area of two hundred thousand square miles. The mountainous plateau in which this vast river system rises is fully three thousand feet higher than the surface of Lake Baikal, giving such a gradient to the streams that their erosive activity would be considerably above that of average rivers. Assuming, however, that it is relatively the same as that in the Mississippi basin, we shall be able to make an approximate calculation which cannot be very far from the truth. ${ }^{*}$

By long and careful experiments conducted by Humphreys and Abbot for the United States Government, it is ascertained that the sediment, consisting of gravel, sand, and mud, which is carried by the Mississippi River past New Orleans is sufficient in quantity to remove one foot of material from the whole Mississippi basin, stretching from the Rocky Mountains to the Alleghenies, in 4,566 years. All this material is being deposited along the margin of the delta which the river is pushing out into the Gulf of Mexico. The annual amount of solid material carried out by the river is estimated by Dana to equal a mass one mile square and twenty-seven feet thick.

In the more mountainous region of Northern Italy, the river Po is bringing sediment down to the head of the Adriatic Sea at a rate which would remove a foot 


\section{Sicutific Crediblity of the i)}

of material from its entire drainage basin once in every seven hundred years. As a striking tangible evidence of the rapidity of this erosion, and the consequent accumulation of material about the mouth of the river, it is worthy of note that the city of Adria, which was at an early period a port of such importance and celebrity as to give name to the sea on which it stood, is now sixteen miles inland.

But, taking even the lower rate of the Mississippi as the standard for that of the Selenga River, we shall arrive at results, which are sufficiently instructive and even startling. All the sediment brought down by the river is deposited in the southern quarter of Lake Baikal. It is impossible to believe that the average depth of this basin was ever more than one-half mile. Taking the length of the southern quarter of the lake basin to be one hundred miles, and its average width thirty miles, which are both liberal allowances, we should have fifteen hundred cubic miles of space to be filled. But, on the basis of the calculated erosion from the drainage area of the Selenga River of one foot in five thousand years, forty cubic miles of sediment would, in round numbers, be deposited in the lake every five thousand years.

The whole portion of the basin, therefore, in which the deposit is made, would be filled up by the sediment 
in 187,500 years. But so little has the delta cncroached upon the lake, that it is certainly not one-fifth full, and probably not one-tenth full. The extensive geological changes, therefore, which have produced this great basin cannot have taken place more than 40,000 years ago, and probably not 20,000 years ago, and may have been even considerably later. Geologically, the time of its formation was during the latter part of the Tertiary or the beginning of the Glacial epoch. Altogether this is one of the most striking and convincing evidences heretofore adduced of the recency of some of the most extensive geological changes which the world has ever witnessed, while it is difficult to see any way in which the figures can be very greatly enlarged.

The great Aral-Caspian depression is another of those vast inclosed basins bearing unmistakable evidence of recent rapid geological changes in the earth's surface. In this case a region nearly as large as the whole United States is without any outlet to the ocean. and is subject to an evaporation just equal to the rainfall. The surface is dotted with dried-up lake basins of greater or lesser size, most of which contain salt beds at their bottoms. Under these conditions one would naturally expect to find the water of the Aral and Caspian seas to be, like that of the Dead Sea and 
214 Scientific Credibility of the Deluge.

Great Salt Lake, salter than the ocean. On the coritrary, the Caspian Sea is only one-third as salt as the ocean, and the water of the Aral Sea is so nearly fresh that animals on the islands freely drink it. The explanation is that the occanic outlet has only recently ceased to exist. Previously the great rivers flowing into these basins had brought in so much fresh water that an oceanic outlet was a necessity, and the seas were partly freshened. The changes which have diminished the rainfall and increased the craporation have been so recent that there has not been time for the seas to become saturated with salt, like most inclosed lakes. All the rivers with their modicum of salt are continually running into these seas, yet their waters are not saturated. The sure inference is that the time during which these agencies have been acting is narrowly limited. The desiccation of this vast region is so recent that the time which has since elapsed must be estimated in thousands, or certainly in tens of thousands, rather than in hundreds of thousands, of years.

This conclusion is supported, also, by the geological evidences that, up to recent times, a vast inland sea as large as the Mediterranean occupied the interior bain of Central Asia known as the Desert of Gobi, around which extensive shore-line deposits of sedimentary material are reported in various places. More- 
over, the early Chinese records refer to this sea, under the name of Han $\mathrm{Hai}$, as still covering an extensive area within the historic period. Lob Nor is, at the present time, the sole remnant of this body of water. indicating a recent period of greater rainfall throughout Asia."

In case of the Dead Sea, we have a depression whose surface is thirteen hundred feet, and its bottom twentysix hundred feet, lower than the surface of the Mediterranean, forty miles away. But the isolation has been so long continued that the water of the Dead Sea is saturated with salts of every kind. Evidence of the recentness of the formation of this deep basin is, however, unmistakable. 'The Jordan, though clear when issuing from Lake Galilee, becomes, before reaching the Dead Sea, one of the muddiest of rivers; whit: numerous wadies of large extent, which are periodically. gorged with water, making them eroding and transporting arencies of the most efficient kind, come down into it from the highlands on either side. For example, the bed of Wady Zuweirah, which enters the Dead Sea just north of Jebel Lisdum, having a width of about ore thousand feet, is covered with boulders a foot and more in liameter, which have been rolled some distaner over a nearly level plain. During most of the 
216 Scientific Credibility of the Deluge.

year, there is scarcely any water in the channel. But evidently there are periodical floods of great violence, and it is they that accomplish most of the erosion of the highlands, and corresponding sedimentation of the lake basins in which they terminate. Why, then, has not the present basin of the Dead Sea been filled up with sediment? Evidently because the bottom of the lake has fallen out in recent geological times.

From the size of the drainage basin, as compared with that of the Dead Sea itself, and from the rate at which sediment is being carried into the sea, it will appear, upon calculation, that fifty thousand years is a longer period than has probably elapsed since the extreme depression of the Dead Sea was formed. ${ }^{6}$ Evidently it is a region in which geological forces have been active with enormous intensity in comparatively recent times.

THE LATEST GEOLOGICAL EDOCH, ONE OF GREAT CHANGES OF LEVEL.

The history of the three lake basins just described might have been introduced under this head. But it will be in point to adduce facts of a more specific character. To this end the entire history of the Glacial epoch is in place. The Glacial epoch, both in Europe and America, was coincident with, if not caused by. 
an extensive continental elevation of the land throughout the glaciated region. Just before the Glacial epoch, as already said, the land in a large parr ut the northern portion of North America stood from two thousand to three thousand feet higher than its present level. The evidence of this is abundant on every hand. ${ }^{7}$ Both the eastern and the western shores of the United States and Canada are bordered by a shelf of shallow water. which, at distances varying from a few miles to a hundred miles or more, suddenly breaks off into much greater depths. The depth of the water on this shelf is less than six hundred feet, while, beyond, it suddenly becomes several thousand feet deep. Now, there is indubitable evidence that, at the close of the Tertiary period, this shelf was dry land, standing at such an elevation that the great rivers coming down from the interior cut channels through it hundreds of feet, and in some cases thousands of feet, in depth. These submerged drainage channels are brought to our knowledge by the sounding-line of the Coast Survey. The Hudson River then found its way to deep water south of New York through a cañon more than one thousand feet deep, extending to its mouth between precipitous cliffs nearly one hundred miles beyond Sandy Hook. The Delaware and Susquehanna rivers found similar outlets through cañons extending far out beyond Dela- 
ware and Chesapeake bass; while the St. Lawrence extended in its lower course several hundred miles through a deep-cut channel in dry land where now we find the Gulf of St. Lawrence and the Banks of Newfoundland. Similar channels intersect the shelf which borders the Pacific (Ocean on the coast of California, Oregon, Washington, and British Columbia. At the same time, numerous borings for oil have brought to light in Central New York, in Ohio, Indiana, and Illinois, many eroded channels in the rocks, now filled with glacial débris, which immediately before that epoch conducted away the drainage of the interior at a depth considerably below that of the present sea-level.

To the same effect is the evidence from Northwestern Europe. On the approach of the Glacial epoch, the North Sea between England and Scandinavia, which is now everywhere very shallow, was all dry land, intersected only by the channel of a mighty stream which conducted away to the far north the combined floods of the Rhine, the Weser, and the Elbe, augmented by all the water which issued from the area of the Baltic and of the eastern watershed of Great Britain. The fiords of Norway then increased their grandeur by the addition of many hundred feet to the present height of their cliffs above the water. To the south, this preglacial continental elevation was sufficient to join Africa 
to Europe across the middle part of the Mediterranean, and to permit the elephant and the hippopotamus freely to roam over the plains of Sicily and Southern Italy. Fresh bones of these animals have been mined for export by the ton from a cave near Palermo.

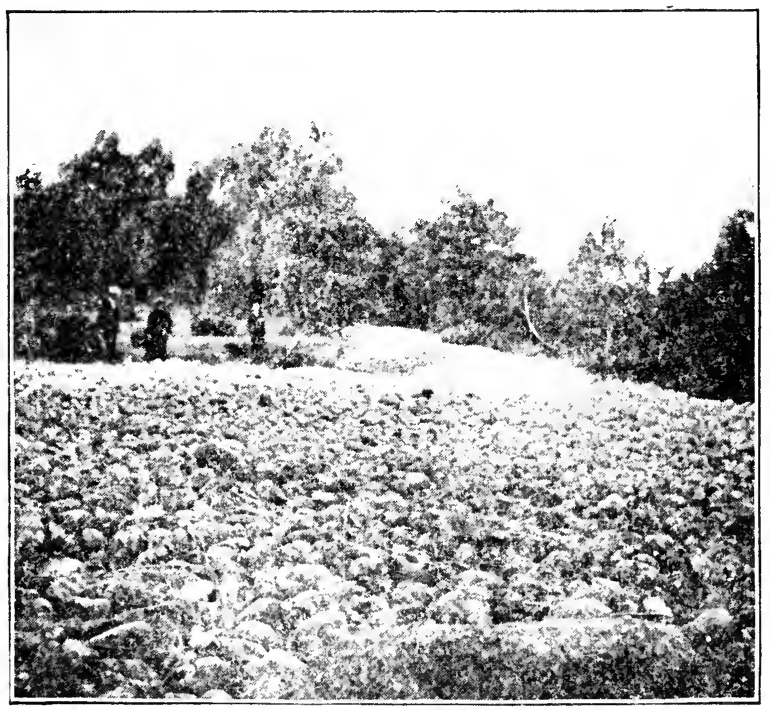

Raised Beach in Sweden. 


\section{THE GLACIAL EPOCH AS A VERA CAUSA.}

THE significance of the Glacial epoch can be fully realized only by those who have made a special study of the subject. Still, there are a few facts which can he briefly stated, and which bear with great force upon the question of the recent occurrence of a period of exceptional instability in the earth's crust; while the proper appreciation of these facts will tend to remove prejudices which the uniformitarian theory has raised in many minds against crediting any such story as that of the Flood. The main facts relating to the Glacial epoch, which are both capable of abundant proof and pertinent to the question in hand, are these:-

At the close of the Tertiary period, snow accumulated over the elevated portions of the northern part of North America and the northwestern part of Europe faster than it melted. Under the pressure of its own weight, this was consolidated into ice, which, under the laws regulating glacial movement, slowly flowed outward from the center of accumulation in lines of least resistance until it was melted by contact with the 
warmer atmosphere in the south. The area which was eventually covered by this glacial mass was about six million square miles, four million being in America, and two million in Europe. Its depth is known to have been one mile in New England, from the fact that it covered the top of Mount Washington, leaving foreign boulders upon its very summit. It is altogethe: probable that its average depth was fully as great as this. In Greenland at the present time the thickness of the ice-covering over the center of the area is probably much more than this.

On this estimate, however, the mass of ice accumulated over the northern hemisphere at the climax of the Glacial epoch would be six million cubic miles, thus adding the pressure of this immense weight over the area of accumulation to disturb the balance of forces which preserve the normal relations between the continents and the ocean. Furthermore, not only was the weight of this mass added to the northern part of the continents, but, to furnish the accumulating snow over this region, an equal amount of water was abstractcd from the ocean. This would be sufficient to lower the level of the ocean two hundred and fifty feet the world over, thus relieving the ocean beds of that enormous weight.

It will help to an appreciation of the tremendous sig. 


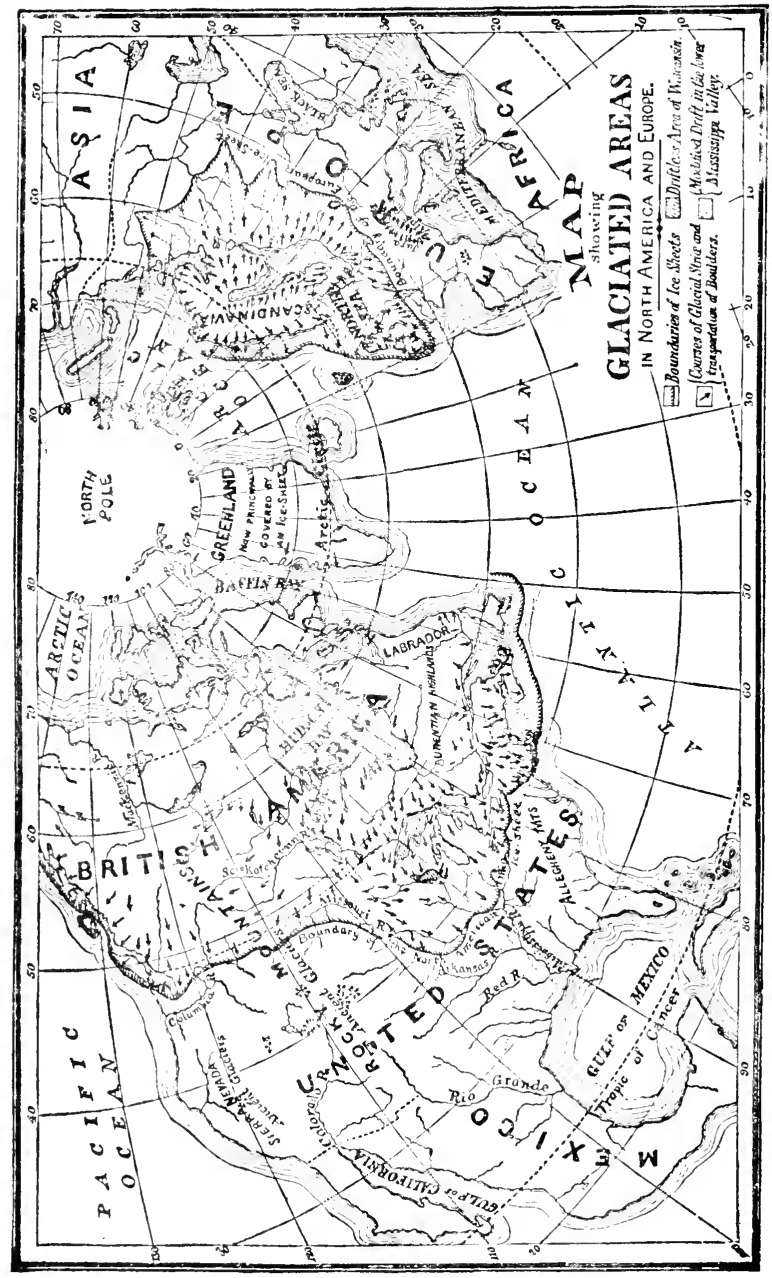


nificance of this temporary transfer of weight from the ocean beds to the continents to note that a mass of ice one mile thick would produce a pressure at the bottom of one hundred and twenty-five atmospheres, equal to two thousand pounds to the square inch, or four billion tons to the square mile. The total amount of pressure thus transferred during the Glacial epoch from the ocean beds to the northern part of America and Europe would be twenty-four thousand million million (24,ooo,o00,000,000,000) tons.

If, as is by no means improbable, the ice was two miles thick ( a little more than that of the Greenland ice-cap), the weight would be twice this enormous amount.

Still better to appreciate these figures, one needs to compare them with those expressing the bulk and weight of the continents. North America has an area of 7,600,000 square miles, with an average elevation above the sea of 2,132 feet, which would make about 3,000,000 cubic miles, or, at our lowest calculation, one-half the amount of ice piled up on the northern part of the northern hemisphere; while, if the ice were two miles deep, the land mass of North America is only one-quarter that of the glacial ice. Reckoning the specific gravity of rock to be three times that of ice, the weight of the entire continent of North America would 
$22+$ The Clacial Epoch as a I era Causa.

be, on one calculation, only one-third more than that of the ice of the Glacial epoch, and, on the othe:- onethird less. The total land area of the world is 55,ooo,ooo square miles, with an average elevation of 2,4I $\mathrm{I}$ feet above sea-level. Even this is (on the lowest calculation), in bulk, only four times, and on the large estimate only twice, that of the glacial ice. ${ }^{1}$

In addition to this, President Robert Simpson Woodward, of the Carnegie Institution, calculates that the attraction of the ice piled up during the Glacial epoch about the north pole would be sufficient to raise the water in that region several hundred feet, and to lower the ocean-level over the main ocean beds about fifty feet. This, therefore, would have to be added to the direct disturbing force of the ice itself.

Now, if the earth be indeed in any degree plastic, it is easy to believe that the transfer of this enormous weight of ice from one portion of the surface to anothe: wou!d produce marked temporary changes in land-level. The piling-up of such a mass of ice over the glaciated area is a cause tending to depress the continents, whose effects greologists are compelled to reckon with. At the sane time it is to be observed that the tendency of this increase of prosure over the glaciated area to depress thie continents is reënforced by the relief of pressure in other portions of the earth's surface, caused 
by the abstraction of water from the ocean. Interest in the problem is further increased by the subsequent melting of this mass of ice, and the return of the water to the ocean beds, thus relieving the glaciated area of the pressure, and restoring it again to its normal condition. If any one can in thought pass lightly over these known great changes which have recently taken place in the distribution of the forces of gravity over the earth's surface, it is because he has not paused long enough upon them to comprehend their significance.

That there is a considerable degree of plasticity to the earth is proved by a wide range of geological facts. The very separation of the earth's surface into land and water, which indicates that the continental areas are elevated portions of the earth's surface, and the ocean beds depressed areas, proves it. Fossil sea-shells upon the summits of our highest mountains give clearest evidence that extensive areas which were formerly buried beneath the ocean have since been raised to great clevations. Indeed, the language which speaks of "the carth's crust" is as scientific as it is popular. As compared with the mass of the earth, the cooled-off outside crust is but a shell sensitively subject to the influence of the shifting of any load from one point to the other, such as is brought to light in the accumulation of glacial ice and its subsequent melting. 
That the earth's interior forty or fifty mis:- ce ow the surface is hot enough to melt all known oriberals is beyond reasonable controversy." So far as man has penetrated the surface in wells and mines, the temperathre is found to increase one degree for every fifty or sixty feet, or one hundred degrees for every mile, which would give a heat of five thousand degrees fifty iniles below the surface. That there is some such reservoir of heat within a moderate distance from the surface of the earth is evident enough from the existence of volcanoes, whose activity we are learning from sad experience has been by no means confince to past ages.

To just what extent, however, the center of the carth is in a fluid condition is not determined solely by its heat. For, upon approaching the center of the earth, the pressure of gravitation so increases that it is supposed to compress the hottest substances into a solid. But, as all concede, there must be, about fifty miles below the surface of the earth, a ring of material, of indefinite thickness, which is in a sufficiently semiplastic condition to allow it to respond to changes in the amount of superincumbent pressure. Upon this molten mass the crust of the earth reposes in a state of equilibrium which is constantly liable to disturbance. The extent of the disturbances to which it is liable is measured by the facts already adduced in the elevation of 
the continents and the depression of the ocean beds, and in the changes which have repeatedly taken place in these elevations as shown in geological history.

Indeed, it would seem that the height of the mountains is limited by the forces which maintain the equilibrium of the earth's surface. Mountains could not be maintained above a certain height without overloading "the low arch of the earth's crust"; so that it would settle down into the semiplastic mass beneath. In short, the crust of the earth is like a pontoon bridge: the more you pile on at one end, the higher it will rise at the other.

This brings us to the main proposition had in view in this part of our discussion. The equilibrium of the earth's surface is so delicately balanced that it is very easy to believe that the disturbances of the Glacial epoch produced such an abnormal temporary instability of conditions that the story of the Flood, when reasonably interpreted, is not encompassed with any more a priori geological improbabilities than is any of the other great facts of geological history.

In my recent excursion across the Asiatic continent I set out with the expectation of finding evidence in Mongolia, Manchuria, Siberia, and along the base of the Tian Shan Mountains that the Glacial epoch was marked by accumulations of ice on the Asiatic conti- 
nent commensurate with those which occurred in North America and Northwestern Europe. But in this I was disappointed. Whatever accumulations of ice have taken place in that region are very small in comparison with those which took place in America and Europe. In consequence of this, it at first seemed difficult to connect with the Glacial epoch the recent depression of the Asiatic continent implied in the story of the Flood, and confirmed by the abundant evidence to be presented in the next chapter.

But, upon reflection, it will appear that a temporary depression of the Asiatic continent would not be dependent upon the overloading of its surface by an accumulation of glacial ice. The simple fact that the ocean beds were relieved of pressure to the extent to which we have indicated, by the abstraction of three hundred feet of water from the whole surface of the ocean, would, very likely, so disturb the equilibrium, that, in the readjustment of forces, the Asiatic continent would sink of itself, and rise again when the glacial ice was melted off, allowing the water to return to its former position.

It is by no means impossible, however, that a see-saw motion between the continents would be the result of the alternate accumulation and disappearance of ice over Europe and America. When they were most 
deeply covered with ice, they would be abnormally depressed; while, upon the melting of the ice and the consequent relief of pressure over the glaciated area, the upward movement would be abnormal, inviting such a flow of the semiplastic magma beneath, that the Asiatic continent would for a time be correspondingly depressed.

\section{RECENCY OF THE GLACIAL EPOCH.}

Evidence accumulates to show that the Glacial epoch, one of the most momentous in the world's history, is a recent event, even as time is reckoned by ordinary standards. For a full statement of the evidence, the reader must be referred to innumerable recent reports of individual observers; but, for practical purposes, a sufficiently full statement of the fact is given in my volume "The Ice Age in North America." Briefly summarized, the facts are as follows:-

I. Nearly all the waterfalls in the glaciated region have come into existence, and so begun their work of erosion, since the melting-off of the glacial ice, and everywhere the post-glacial gorges worn by the recession of the waterfalls are such as could be produced in a few thousand years by the forces now in operation.

For example, the cataract of Niagara began its work when the glacial ice had melted off from Central New 
York sufficiently to allow the drainage of the Great Lakes to pass through the Mohawk into the Hudson. The length of the gorge formed by the recession of the falls is only seven miles, or, in round numbers, thirtyfive thousand feet. The geological conditions throughout this district are nearly uniform. Recent surveys of the falls, compared with those made fifty years ago, show that the recession is at the rate of nearly five feet per annum, which would place the beginning of the falls at about 5000 B.c., making it contemporaneous with a high civilization in Egypt and Babylonia. There is no way of lengthening this chronology of the great cataract, except by introducing theories concerning the changes in the direction of the drainage of the Great Lakes which would diminish the water-supply, and so the rate of erosion. But it can be easily shown that this need not lengthen the time more than two thousand or three thousand years.

Evidence from the recession of the Falls of St. Anthony, at Mirneapolis, points to approximately the same date. Upon comparing the situation of these falls, as shown by the description and map of the Catholic mis-

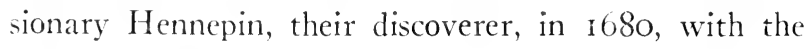
present position of the falls, it appears that they too have been receding at the rate of five feet per year; while the post-glacial gorge, extending from Fort Sneil- 
ing up, is of the same length with that of the Niagara gorge, namely, seven miles.

Approximately similar results are obtained by the study of numerous smaller waterfalls, which can be found all over the glaciated region.

2. The existence of the innumerable lakes and ponds which dot the glaciated regions both of Europe and America points to a recent origin of those bodies of water; while in almost all cases their formation can be traced to the influence of the Glacial epoch. With few exceptions, the greater lakes are formed by the dammingup with glacial débris of preglacial watercourses, so as to divert the drainage to other channels. But, as we have already seen, the erosion which will eventually drain the lakes has proceeded only a short distance, while the majority of the smaller lakes which occur in Northern Germany and Russia, Finland. Scandinavia, Scotland, Ireland, New England, Northern New York, Michigan, Wisconsin, and Minnesota, and all of Canada, are what are known as "kettle-holes," being merely hollows where lingering masses of ice of the Glacial epoch were deeply covered with glacial débris. These, upon finally melting, have left depressions, which, in most cases, have subsequently been filled with water, but frequently, where the soil is porous, are simpiy dry hollows. Now it is 
232 The Glacial Epoch as a V'era Causa.

easy to see that the wash from the hills surrounding these lakes, and the accumulation of peat around their edges, are constantly at work to fill them up and obliterate them. In many cases the work to be done has been so slight, and the forces in operation have been so rapid, that they have been obliterated, and their pre:ence is simply marked by peat-bogs. Another force working to destroy these glacial lakelets is the erosion of the water passing through their outlets. This constantly tends to lower the outlets and drain the basins. A broad study of these facts leaves an irresistible impression upon every one who gives attention to them, that the age of these lakelets is brief. Their age is certainly to be reckoned in thousands of years, rather than in tens of thousands.

3. Another method of obtaining an approximate estimate of the date of the close of the Glacial epoch is open to the inspection of almost every one, in the amount of post-glacial enlargement of the valleys of the streams, both great and small, which carry away the drainage of the glaciated region. As good an illustration as can be found (but it is only one of ten thousand) exists in Plum Creek, a small stream passing through the village of Oberlin, Ohio. The valley is twelve miles long, and it is wholly eroded in the uniform glacial deposit, known as "ground moraine" or 
The Glacial Epoch as a Iron Guinsa. 233

"boulder-clay," which covers the region. In the lower part of this valley or trough, a section a mile long has been carefully measured by my college classes, revealing the fact that the total amount of erosion accomplished by the stream since it began to flow over the surface at the close of the Glacial epoch has been to wear a channel averaging three hundred and fifty feet in width and twenty feet in depth. It is easily seen that, as the stream in its meanderings swings from side to side of this channel, it is constantly increasing its width, and, as the gradient is twelve feet to the mile, also is slowly adding to its depth. By calculations drawn from the rate at which this small stream is enlarging a new channel, which was made for it a few years ago in the construction of the village waterworks, it is clearly evident that ten thousand or twelve thousand years is a maximum limit of time necessary for the total amount of erosion which has taken place.

+. In many places in limestone regions, large fcrcign boulders were left, when the ice melted, resting i.pon a surface polished by the ice which had previously passed over it. The action of subaërial forces in slowly dissolving limestone (a process with which we are too familiar in the decay of marble monuments in our humid climate) has lowered the general level of the limestone surface, except where it was protected 
$23+$ The Glacial Epoch as a I'ra Causa.

underneath the boulders mentioned, so that these are found to stand on miniature pedestals. But in all cases these pedestals, never more than a few inches in height, are so low that, upon the most conservative estimate, they indicate only a few thousand years during which the present conditions can have been in existence.

To such an extent has the evidence from all these sources accumulated in the past few years, that they can no longer be ignored. Professor Rollin D. Salisbury, of Chicago University, one of the most competent and judicious authorities upon the subject, thus writes in his recent (1902) final report upon the glacial geology of New Jersey:-

"The date and duration of the Glacial epoch are matters of the greatest interest, but neither has been determined with numerical exactness. Many lines of calculation, all of them confessedly more or less uncertain, point to the retreat of the last ice-sheet from the northern part of the United States six thousand years or ten thousand years ago. While these figures are to be looked upon as estimates only, there are so many lines of evidence pointing in the same direction that the recency (geologically speaking) of the last glaciation must be looked on as established. The best date for the calculations which have led to the above resuits are fumished by Niagara Falls and the Falls of St. Anthony, at Minneapolis. In each case, the distance 
the falls has receded since the ice disappeared, and the present rate of recession are known with some degree of approximation to the truth. Assuming the rate of recession to have been uniform, the above results as to duration of post-glacial times for these localities are obtained.

"A strong argument for the recency of the last glaciation is the slight modification which the surface of the drift has undergone. This sort of argument does not easily lend itself to numerical results. A summary of the various estimates of the duration of post-glacial time is given by Wright in his Great Ice Age [Ice Age of North America]" (p. 194).

Thus, by attention to the general conditions accompanying the Glacial epoch, we are led to the recognition of the existence of a unique period of instability in the relations of land and water levels which passed away only a few thousand years ago. For a brief geological period the ocean beds were relieved of an immense mass of water, which was piled up in the shape of ice upon the northern continents. After a time, which was very brief as geologists reckon it, this ice melted off, relieving the glacial area from its pressure, and restoring it again to its original place in the ocean. During this process a general subsidence of the continental masses is not only far from improbable, but actually to be expected. 
236 The Glacial Epoch as a Vera Causa.

But the forces in operation are too vast and complicated to permit us to work out their effects in detail. Usually, however, in such cases the results culminated towards the climax of the period, in an epoch of rapidly changing effects.

The geologist, therefore, need not be disturbed by such a consummation of events as is described in the biblical story of the Flood, but he well may be surprised at the sobriety of the account, at the prominence given to "the breaking-up of the fountains of the great deep," and at the assurance that the earth is no more to be destroyed by a flood; for these characteristics of the biblical story are not the natural products of the human imagination, but show that the narrator was restrained, either by personal knowledge of the facts or by the guidance of divine inspiration. The glacial geologist especially may well be impressed by the announcement that the danger of so universal a deluge had passed away, since he also now discerns a reason for the present stability of the earth's crust in the passing-away of the temporary disturbing conditions connected with the Glacial epoch. Indeed, geologists agree that the present stability of the earth's crust is exceptional. ${ }^{3}$

In the following chapter we will present a remarkable series of facts, many of which have recently come 
to notice, going to show that the changes of land-level which are here seen to have been probable, have actually occurred since man came into existence. While, as already remarked, this cannot be expected to prove the truth of the biblical narrative in detail, it may be expected to show that there is no valid scientific reason for rejecting the historical account of the Flood. In other words, the occurrence of the Flood does not make extravagant demands upon our scientific credulity. 
CHAPTER IX.

\section{EVIDENCES OF A DELUGE IN EUROPE.}

According to the account of the Flood in Genesis, while it was so extensive as to need special arrangements to preserve the animals associated with man, the catastrophe was, as geologists reckon time, of short duration. Still, if we can consider the one hundred and twenty years of warning which was given to Noah as covering a period of subsidence, culminating in the final catastrophe described by the sacred writer as of a year's duration, we should have a progress, in the main, so slow and gradual that it could scarcely be observed from year to year, though very likely producing the most wide-spread destruction of animal species which so evidently took place about the close of the Glacial epoch; while the more rapid rise of the land, intimated in the biblical story by the short duration of the Flood, would account, as we shall see, for a large class of phenomena, which we are about to describe.

But the influence of such a brief subsidence must be looked for, not in the greneral phenomena connected with the fossils in the ordinary rocks or with the dislo- 
cation of mountain strata, but in those superficial deposits of gravel, sand, loess, and clay which everywhere girdle the shores, border the valleys, and mantle the upland plains of the continents. To discriminate in these superficial deposits between those which are due to the slow action of existing agencies and those which are the result of a wide-spread movement is by no means always an easy matter; yet much has been done in this direction during the last twenty-five years, with the remarkable result, that, whereas existing local causes are seen to be sufficient to account for the larger part of the erosion of gorges and river valleys and the deposition of sediment of various degrees of coarseness over broad plains, a large residuum of phenomena demands the presence of causes which have now either altogether ceased their activity, or have so diminished their force as to be inadequate for the explanation of the facts.

I have perhaps been as active as any one in efforts to discriminate, in the superficial deposits in the northern part of North America and in Northwestern Europe, between those which are the direct result of the great ice invasion of the Glacial epoch, ${ }^{1}$ and those which are the effects of local and more limited causes. and have, therefore, been strongly predisposed to attribute as much as possible to direct glacial agency, es- 
pecially as it so easily accounts for the larger part of the gravel deposits over these areas which were earlier attributed to a submergence of the continent or to the action of floating ice. But longer and wider study of the facts of surface geology reveals more and more clearly a considerable residuum of phenomena which indicate a brief post-glacial submergence, since man's advent, of a large part of Europe and Asia.

\section{EVIDENCE FROM EUROPE.}

The residual facts pointing to this conclusion in England and the continent of Europe have been very fully stated by the late Professor Joseph Prestwich, one of the most eminent, cautious, and unerring of recent geological observers. ${ }^{2}$ The conclusions of Professor Prestwich we have already given with considerable detail in "Scientific Aspects of Christian Evidences." 3 But, for our present purpose, it will be in place to present a much ampler statement of the case. Fully to appreciate the force of the facts, however, one needs to go carefully through Professor Prestwich's elaborate monographs referred to, or, better still, follow him, as I have done to a considerable extent, over the fields described.

The evidence is classed under three heads; namely, the Rubble Drift, or "Head," of Southern England 
and Northern France; the Ossiferous Breccias of England and the Continent; and the High-level Loess of France and Central Europe.

I. The Rubble Drift, or Head.-At numerous places over the southern counties of England and on the south side of Dover Strait at Sangatte, near Calais, in France, there are deposits of angular gravel bearing no relation to the present drainage systems of the country, and containing palæolithic implements and the bones of extinct animals associated with prehistoric man. This drift is found as far inland as the vicinity of Oxford, and at an elevation on the Cotteswold Hills of about nine hundred feet.

A typical illustration of this deposit is to be found at East Brighton, the great watering-place of Southern England, where it can be still studied to an excellent advantage. The deposit is here eighty feet thick, and the surface forms a continuous slope with the chalk cliffs, rising into the interior. Formerly the deposit extended a considerable distance into the sea, but the larger part of it has been eroded by the waves. The accompanying illustrations will aid in conveying the important facts. At the base of the rubble drift there is an old sea-beach, now elevated fifteen or twenty feet above the reach of tide. This can be seen along 
$2+2$ Ezidences of a Deluge in Europe.

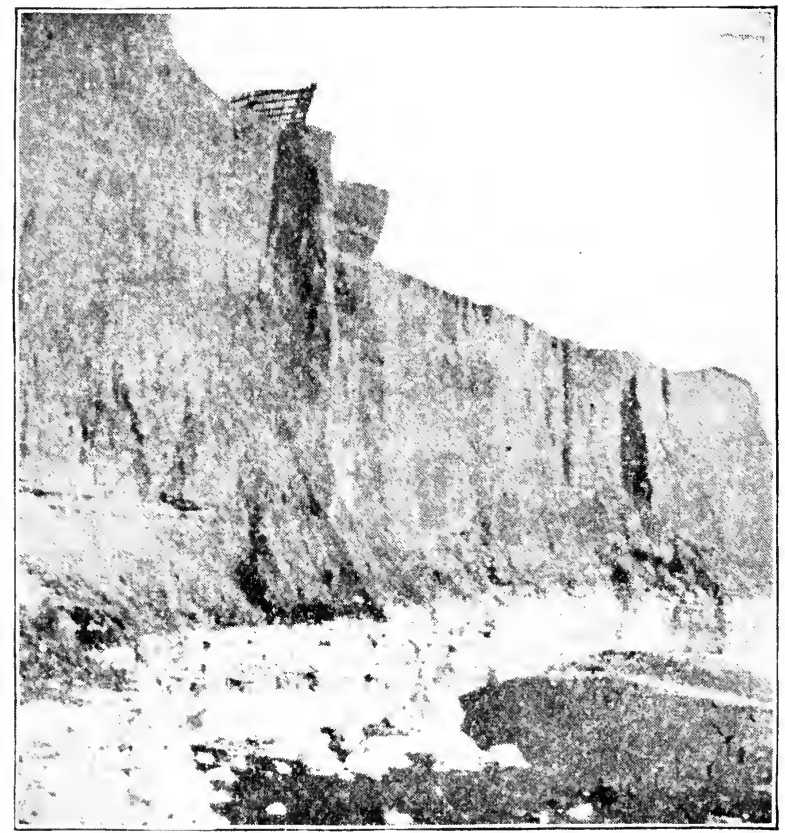

A General View of the Rubble Drift at East Brighton, England.

The view was taken looking eastward. The total elevation is 80 feet. The buried raised beach is dimly seen a few feet above the rock. The surface slopes grachally to the highland back from the shore. For a clearer view of the beach, see page $2+4$. 
the coast for a distance of a mile or more, resting upon a rocky foundation.

The superincumbent mass of the deposit must have accumulated in very peculiar circumstances. It has no regular stratification. An unstratified mass of sharp angular flints and chalk fragments constitutes the surface. Below this there is a series of irregular lenticular masses, of the same character, containing fragments of the Tertiary rock which surmounts the hills in the near vicinity. Projecting from the face of the cliff of this material as it is exposed are large blocks of this Tertiary sandstone, either angular or with angles but slightly worn. One of these measured by Professor Prestwich was $8 \times 2 \times 2$ feet. The deposit shows clear marks in some places of rapid and tumultuous accumulation, while in others there is seen the fine lamination produced by tranquil water action and deposition. "But there is an entire absence of any of the effects produced by continuously running water, nor is the angle of bedding of the mass such as would be formed under subaërial conditions by rubble falling over the top of the cliff, which would lie at a much greater and more uniform angle." In this deposit are found numerous mammalian remains characteristic of post-Tertiary times. Among them were those of species of elephant, rhinoceros, reindeer, hippopotamus, horse, hog, and ox. 
244 Evidences of a Deluge in Europe.

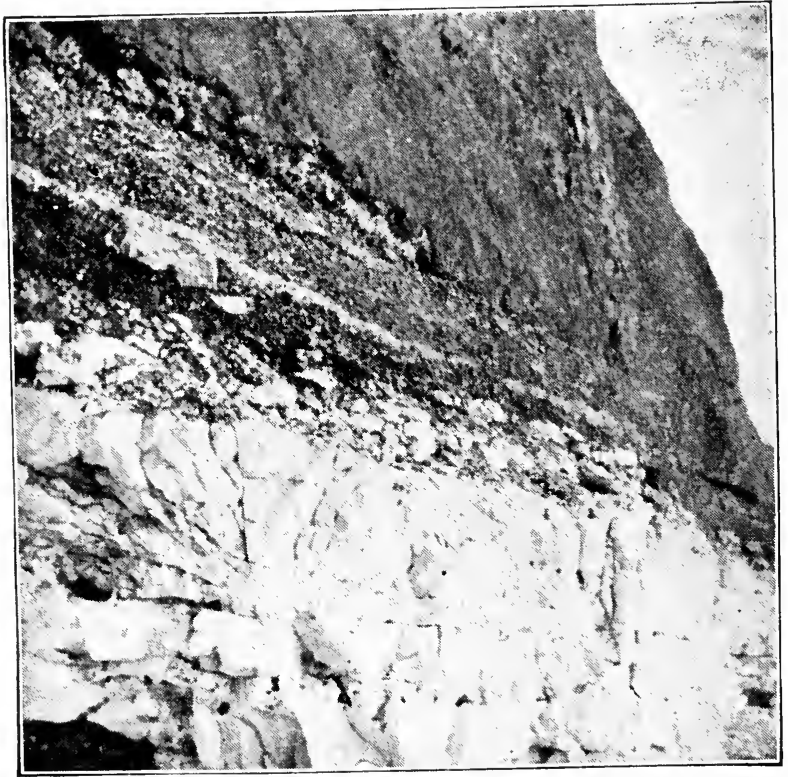

Near View of the Raised Beach at East Brighton.

This shows the base of the rubble drift, with a large unworn sandstone block in the drift. Elephant bones were found here near the base of the drift. For the general situation, see illustrations on pages 242 and 247 . 
The elephants' teeth and the bones in general are in such a perfect state as to show that they could not have been transported for a long distance. They showed signs of fracture, but not of wear.

The rubble drift at Brighton is only one instance out of more than twenty in Southern England carefully described by Professor Prestwich. Prominent among the places are Dover and Folkstone, Eastbourne, Birling Gap, New Haven, Port Slade Station, the Sussex Coast Plain, Hayling Island, the Isle of Wight, Isle of Purbeck, the Isle of Portland, the South Devon and Cornish coasts, the north coast of Cornwall and Devon, the Somersetshire coast, the lower Severn, Swansea, Gower, and Pembrokeshire.

An important observation relates to the blown sand, or old dunes, which in various places occur between the rubble drift and the raised beach, especially on the north coast of Cornwall and Devon. These indicate that, after the old beach had been elevated, there was a considerable pause in the earth movements, sufficient to allow the accumulation of extensive dunes. Then followed the depression during which the rubble drift accumulated upon the top of the dunes. The existence of these dunes between the raised beach and the rubble drift indicates that the subsidence of the land preceding the accumulation of the rubble drift was rapid. Other- 
2to Eicidences of a Deluge in Europe.

wise the waves of the ocean would have leveled and obliterated the dunes.

The rubble drift differs in important respects from all ordinary gravel, such as is found along river courses or on the beaches of oceans and lakes, in

( I) The angularity and sharpness of the harder constituent débris. Evidently the material has been moved but a short distance; since both the fragments of stone and the fractured bones retain their sharp angles.

(2) A second peculiar characteristic is that the material is all of local origin, and is derived from the higher grounds of the immediate vicinity. A significant fact, also, in connection with this, is that the drift is arranged around the base of the higher land, as if it had been swept in all directions from it, yet so far from the base that the agency of distribution could not have been running water. In some cases, as on the South Downs, at Port Slade, west of Brighton, this extends from two to five miles over a comparatively level surface. The material, however, is not collected in deltas, as would be the case if it were transported by small streams, but is pretty equally distributed around the base; nor does it have any regular stratification, as would he the case if it had been transported by ordi. nary water action. 


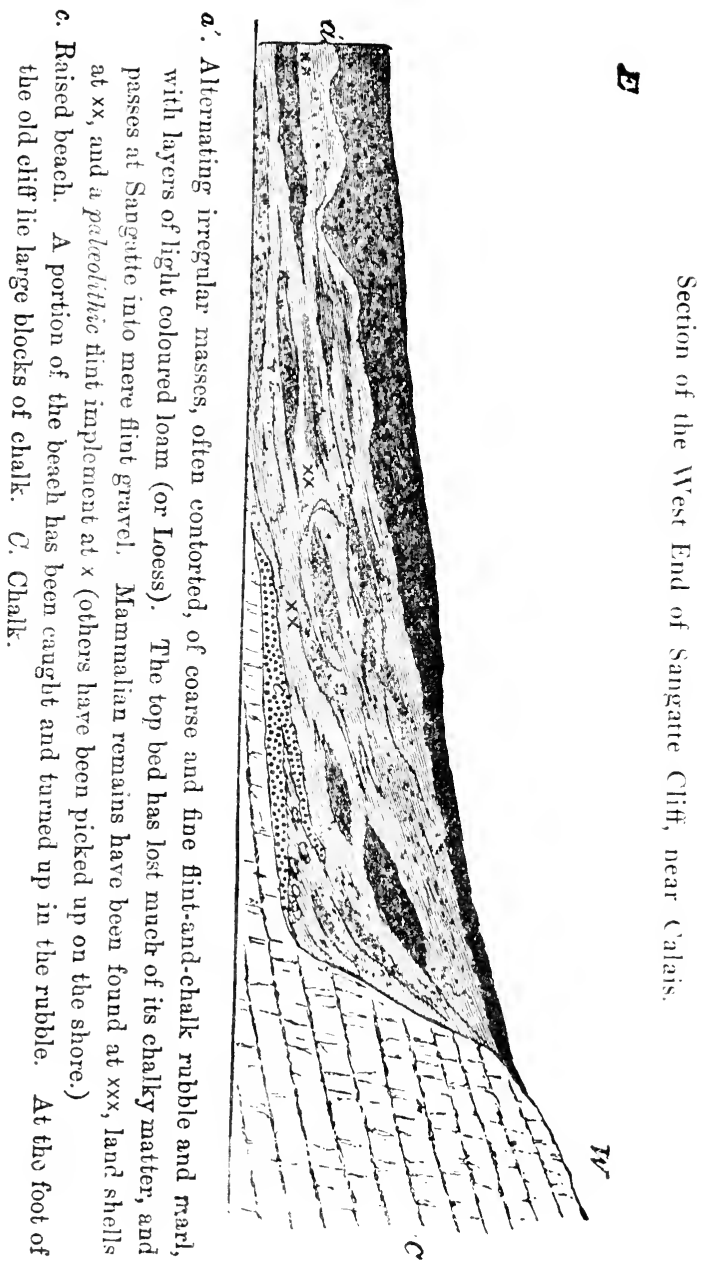


(3) There is a total absence in these deposits of marine and fluviatile shells. This has ordinarily been taken as conclusive evidence against the origin of these deposits during a period of submergence. In the opinion of Professor Prestwich, however, it is simply evidence of the brevity of the submergence, the time of its continuance having been too short to permit the establishment of colonies of shell-fish of any description.

Of all the unsatisfactory theories proposed to account for these facts, that involving the agency of ice and snow sliding down the hill slopes, aided by the running off of water from the melting of the ice and snow, is the most plausible. But insuperable objections to this theory are forcibly urged by Professor Prestwich as follows:-

" $\mathrm{By}$ this means débris might be propelled over the edge of the cliff along its whole face, without wearing very definite channels, but in times of thaw the escape of the surface-waters must have ended in producing results analogous to those caused by heavy rainfalls. By ice and snow the rubble might also have been driven over smaller gradients and to a greater distance beyond the cliff, but I doubt whether it could, as at Godrevy, have been propelled for a distance of above two hundred feet from the face of a cliff; for the cliff is not more than forty feet high, and the hill at the back does 
not rise higher than one hundred and fifty feet, and that at a distance from it of some two hundred and fifty feet. Besides, the slope of the rubble does not exceed an angle of $10^{\circ}$ to $12^{\circ}$; whereas the angle of repose of loose gravel is $40^{\circ}$, and that of rubble $45^{\circ}$, though these would be somewhat diminished, but not to that extent, by the greater fluidity of the mass produced by the snow. Nor would a sludge of ice, snow, and rock-débris in motion be more favorable than running water for the preservation of the land-shells and mammalian bones.

"Another difficulty in the way of the ice-and-snow hypothesis is the small size of the areas (at times to be measured by acres) that form the centers of dispersion, and the small gradients and short lengths of the slopes. It is very different in a mountainous district, where the frozen masses are large and the slopes steep; but with the gentle slopes of the South Downs how would the winter's ice and snow on them have been equal to the propulsion of the débris of flints and loam across the Sussex Coast plain-a distance of from two to five miles over a comparatively level surface? Or, to take the case of the Isle of Portland, is it likelywith its length of three miles and its gradient of about one in forty feet-that the ice and snow could have forcibly driven down the 'head' in one direction over the raised beach southward, and in the other direction have sent the large mass of Chesilton débris northward? Even in the case cited by Mr. Drew, where the mountains rise several thousand feet above the valley, the 
cones of dejection do not extend more thar, orre mite from the point of discharge, while at the base of the cones the lébris has a thickness of five liundred feet. Nor is it possible that either snow or rainfall on open ground could have transported the huge blocks found in the 'head.'

After, in like manner, considering all the other theories put forth to account for this remarkable formation, it would seem that there is only one left which sufficiently covers all the facts, namely, that this rubble drift has been swept off from the higher surfaces to the lower in every direction by a general movement of overlying water produced by the elevatory force of successive earthquake shocks, such as cause tidal waves like that which destroyed the city of Lisbon in 1755. and which have been of frequent occurrence during the past century on the west coast of South America. These waves are produced by a sudden uplift of the bottom of the ocean, where the water is comparatively shallow. In the recent earthquake which destroyed San Francisco, the vertical movement of the land amounted to ten feet in places. But most instructive of all is the report made the present season by Professor R. S. Tarr of his studies along the "fault" produced by the eatrthquake of 1899 along the coast of Southeastern Alaska. 
"On one stretch of coast," he says, "the uplift amounted to eighteen or nineteen feet, and opposite this, on the other side of the fiord, from thirty to fortyseven feet for a distance of five or six miles. This is the greatest uplift of the land ever recorded as having occurred at a single period of time."

"This deformation of the earth's crust, with its accompanying uplift of the coast, and the associated earthquake shocks, is of decided geological interest entirely aside from the fact that it is the greatest change of level so far recorded. It is a representation of the processes by which mountains have grown in the pasta lesson of the present for use in interpretation of the changes of the past. It shows us plainly, what other regions have shown less strikingly, that the process of mountain growth is still in operation: and it tells us not only that the St. Elias chain is now growing, but that in a single month it was uplifted, in at least one point, as much as forty-seven feet.

"We do not know how far this uplift extended on either side of Yakutat Bay; but the fact that there was such a vigorous shock at the Muir Glacier in the same month suggests the probability that it extended at least one hundred and thirty-five miles towards the southeast."

We will permit Professor Prestwich to explain the formation of the rubble drift in his own words:-

"It is evident that the force-whatever it waswhich determined the formation of the rubble drift 
acted from above downwards. This, under certain circumstances, might have been the result of the descent from the hilltops of ice and snow, or of water. Ice might have acted in some respects in accordance with the observed phenomena, but in other respects there are the objections I have already named; and with regard to rain and surface-waters, the results are, as I have shown, irreconcilable with their agency. But there is another form under which we may consider the action. of water, and this, although not free from objections, answers to all the physical conditions of the case.

"It is that of water in a body, not moving rapidly over the surface as in a wave of translation, but displaced from a state of rest, while the land is in process of elevation from beneath it. There is the objection, amongst others, to a wave of translation that it would carry the débris in one prevailing direction, and in each locality we should have foreign elements more or less largely introduced, and the drift assuming a 'crag-andtail' arrangement behind the hills; whereas no such distribution prevails, but on the contrary we have in the area we have described a number of local centers from which the drift diverges in different or in quaquaversal directions and combines in the intervening valleys. This is a result which would necessarily follow on the emergence of land from beneath a body of water, and such seems to me the most probable solution of the problem we have before us.

"I am therefore led to suppose that a submergence of the land which, judging from the heights at which 


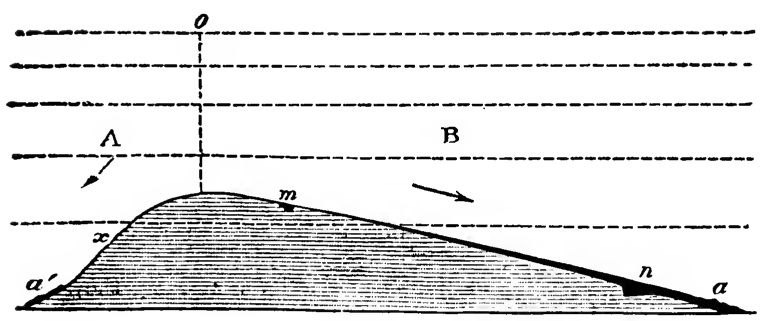

Diagram showing the Direction of the Currents on a Hill Range during Uplift.

" $o$ being the parting-line or watershed between the superincumbent waters $A B$, the divergent currents during uplift will be in the directions indicated by arrows; but while A moves down a short steep slope for a distance $x$, B passes over a surface equal to some multiple of $x$ in the same time. Consequently there will be, independently ot other causes, a larger volume of drift collected at the base of $a$ than of $a$, and this disproportion is very apparent in the case of most of our Chalk ranges.

"Where the course of the ossiferous drift is along made, narrow channels, it would pass down them and spread out fan-shaped at their termination, as at Upchurch and Farnham." 
the rubble drift is found, could not have been less than one thousand feet, followed immediately upon the epoch of the low-level valley drifts and the Caves. There is little or nothing to show as a direct consequence of the subniergence. The land over which the waters spread seems to hre undergone but trifling alteration or denudation. The raised beaches exhibit in consequence thereof no apparent erosion, and the blown sands only slight denudation; and this may be due to the impact of the 'hrad.' It is even difficult to say whether their irregular thickness and eroded surface resulted during the subnergence or emergence of the land. I can only conclude that the submergence was slow and gradual, yet sufficiently rapid to prevent wave-action from removing the whole of the blown sands, or from forming terrace's, which it would have done had the fall been prolo:y or subject to long interruptions. For the same 1rason no portion of the strand was washed on to the isnd.

"The absence of marine shells in the submerged land may seem a difficulty. Had the submergence been of long duration, a marine fauma would necessarily have established itself; and I can only account for its absence by supposing that reellevation followed, after but a short interval, on the previous subsidence. The physical results of that elevation are sufficiently definite to justify our assumption, and are explanatory of the conditions under which it was in all probability effected.

"Mr. W. Hopkins" has shown that if a considera- 
ble area at the bottom of the sea were suddenly' elevated, a ware of translation accompanied by a current, the velocity of which would depend principally upon the depth of the sea, would diverge in all directions from the central disturbance. Calculations, he says, 'prove beyond all doubt that paroxysmal elevations, beneath the sea, varying from fifty to one hundred feet in height, may produce currents of which the velocities shall vary from at least five or six to fifteen or twenty miles an hour, provided the depth of the sea do not exceed eight hundred or one thousand feet.' In considering the magnitude of the blocks which might be moved, he found that the force exerted on the surface of given magnitude increases as the square of the z'elocity, and that it "varies as the sixth power of the ielocity' of the current.' But the movements must be repeated for large blocks to travel beyond short distances.

"It is evident that we have in this form of disturbance an engine of enormous power; and though our hypothesis does not deal with the great changes and powerful currents contemplated by Mr. Hopkins, we may infer what the results might be with even a fractional proportion of such changes. Movements of this character would, like Nasmytl's hammer, be capable at times when the uplift was rapid of exerting enormous force; while at other times, when the uplift was slow, the action might be of the most gentle character. Hopkins's calculations were made for one central area of elevation, and dealt with surrounding level surfaces. In the case before us the area of elevation consisted of 
a variable and uneven land-surface, so that each hill or group of hills formed a center for the divergent currents, the velocity of which would further vary according to the varying gradients and lengths of the slopes.

"It follows from these premises that the character of the deposits formed under such circumstances will afford a relative measure of the velocity and duration of the currents under which they were accumulated. Where, for example, the sediment is fine, we may conclude that the velocity was slow, and the rise which gave origin to it small. When, on the contrary, the materials are coarse, we may suppose the rise to have been more rapid and the velocity of the current greater. Where, again, large blocks have been transported, a more energetic movement is made manifest. Some indication also of the duration of the uplift is afforded by the mass of the material moved and distance traversed."

2. Ossiferous Fissures.-The same theory is demanded to explain the "ossiferous fissures" abundant in Southern England and in France, and long ago described by Buckland in his "Reliquiæ Diluvianæ," but not fully understood by him. These fissures abound in the limestone regions of Southern England. They are not caverns in the ordinary sense of the word, but simply fissures, open at the top and extending down perpendicularly, or at a slight inclination, sometimes a hundred and forty feet. They are filled with angu- 
lar rock fragments, broken and splintered bones whose fractured edges are unworn and sharp, all cemented together in a matrix of sand, earth, and clay through which lime has filtered, making what is called a breccia. The bones represent the horse, ox, deer, wolf, hyena, tiger, hare, water rat, weasel, boar, and some other animals.

It is acknowledged by all that these fissures have been filled in from above, and it was the opinion of Dr. Buckland, that the process had been very gradual, and that the animals had accidentally fallen in from time to time. An unanswerable objection to this theory is, that, though the opportunities for observation have been very extensive, in no case has a complete skeleton of any animal been found, or even scattered bones that would make a skeleton. If animals had fallen in, as Buckland supposed, it is inconceivable that this result should have followed. In the fissure at Oreston, Mr. Cottle collected I,587 teeth of the animals above mentioned, 147 jaws, 250 vertebræ, and 26 skulls; but there was not a single whole skeleton, nor did any of the bones show marks of wear, such as would appear if they had been rolled along by a running stream of water, nor did any show the marks of hyenas' teeth, which are common upon the fragments of the ordinary caves. 
After considering exhaustively all possible modes of accounting for these facts, P'rofesior Prestwich finds himself limited, as before, to the hypothesis of a brief submergence of the land, such as would drive the animals in a heterogeneous mass to the higher lands, where they would be drowned, and their remains scattered over the surface. After time enough had elapsed for their carcasses thoroughly to decay, the reëmergence of the land distributed the bones by the same process that determined the distribution of the rubble drift. As the material was swept along by the successive impulses of uplift beneath the water, the fissures along the slopes became filled in the heterogeneous manner described.

Among the most interesting and instructive fissures supposed to have been filled in this way is that at Santenay, a few miles south of Chalons, in Central France. This is situated upon an isolated hill connected with the range of Cote-d'Or, I,O3O feet above the valley of the Sanne, which is here six hundred feet above the sea. Two ordinary bone-caves occur upon the opposite sides of the hill, containing remains of the horse, wolf, fox, hear, lion, deer, ox, elephant, and rhinoceros.

The fissure under consideration is near the summit of the hill, and is filled with a breccia" composed of the fragments of the adjacent rocks, pro bedded in a yellow or brownish earth, with bones w . t 


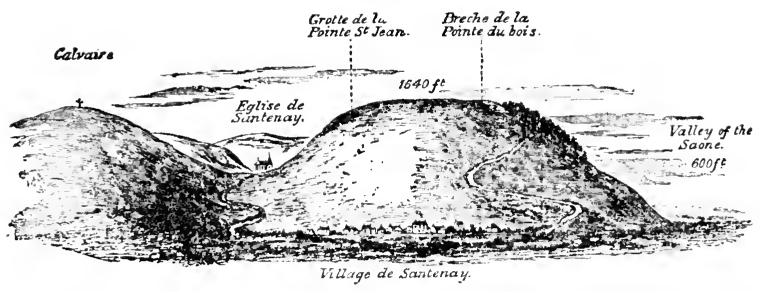

The Mountain of Santenay.

Concerning the above illustration, taken from Prestwich, he further remarks: $\mathbf{I}$. That it is outside of the Alpine glaciated region, and could not have been overtopped by floods in the Saône, caused by a glacial dam at Lyons. 2. That, as there were no entire skeletons in the fissure, and indeed none in any of the similar fissures in France, the bones could not have accumulated by the chance falling in of animals. The bones were without order and in no possible relative proportion. 3. That, under extreme glacial conditions, herds of such animals would have not resorted to high hills, but would have retreated to the open plains. "It is inconceivable that under any ordinary circumstances the predaceous animals and their victims should have congregated together on the summit of a high, steep, and isolated hill." + That it is not possible to suppose the animals were driven to the summit by floods produced by excessive rainfall, unless it were a hundred times greater than at present. The general opinion of the members of the Geological Society of France who risited the place in 1876 was, that "the animals had fallen victims to floods, but whether caused either by dams of ice, the melting of snowfields, or excessive rainfall, was left indeterminate." 
were determined by Professor A. Gaudry to be of the cave lion, lynx, horse, wolf (very abundant), fox, badger, bear, hare, rhinoceros, hog, ox, and deer. The bones were in a very broken state. M. Gaudry observes that their accumulation could neither be attributed to man nor to animals, for the fractures in no way resemble those made by man for the purpose of extracting the marrow, and, notwithstanding the abundance of wolves, none of the bones show traces of having been gnawed by carnivora. How then could this collection have been brought together? As $M$. Gaudry justly remarks, ' why should so many wolves, bears, horses, and oxen have ascended a hill isolated on all sides?' M. Gaudry further remarks that the deposit seems to have been formed by water precipitating the breccia and the bones into a fissure. 'But whence,' he says, 'have come the waters sufficiently abundant to bring together the bones?' The fissure is so near the top of the hill that there is little gathering ground above it, and had the bones and fragments of rock been carried in by a stream or torrential rains, they must have shown more or less wear, and have lost their sharp angles."

After duly considering all other suggested hypotheses, Professor Prestwich applies his theory for the solution of the problem in the following forcible paragraph :-

"The condition and position of the bones are, on the other hand, at Santenay and Pédémar, as they are 
at Oreston and Catsdown, such as $m$ gh result from the effects of a gradual submergence the land. For a submergence of the character I hav : described would naturally drive the animals in the plains to seek refuge on the higher hills. Flying in terror and cowed by the common danger, the carnivora and herbivora alike sought refuge on the same spot, and alike suffered the same fate wherever the hill was isolated and not of a height sufficient for them to escape the advancing flood. We may suppose the subsidence to have been so slow that there was no sudden rush of water to carry the bodies far away, so that as they decayed, the limbs fell and were scattered and dispersed irregularly on the submarine surface. When that surface was again upheaved, the bones and detached limbs, together with the detritus on that surface, were, as I have before explained, carried down by divergent currents to lower levels, or they fell into fissures of the rock over which the detrital matter passed, or else, when facing the coast, over the ledges of the old cliffs rising above the raised beaches. Swept down by the intermittent currents produced by the more or less rapid uplifts, and falling with the mass of detritus in a body over the old cliffs or into the open fissures, the bones, in the one case as in the other, were broken and smashed in the extraordinary manner we now find them. Added to this was the fall, caused by the earth tremors inevitable with such movements, of fragments of rock, some of large size, from the sides of the fissures, so that very few of the bones escaped whole. At the same time, the 
action was of too short duration, and the transport was bo short a distance to wear down the sharp angles either of the rock or the bone fragments. Raised again to the surface, the rain waters, perolating through the calcareous rocks traversed by the fissures, and carrying down carbonate of lime, have generally cemented the debris of the fissures, and occasionally of portions of the 'head' (Brighton), into a hard brecciated mass from which it is now difficult to extract the bones. Where, on the contrary, the debris remained loose on the surface and formed permeable superficial drift, the effect of water percolation has been to remove the calcareous matter together with the hones, so that where thus exposed, the rubble is more untossiliferous than when it hes in fissures or hollows where the surface waters could not freely percolate."

An equally striking application of the theory is formd on the rock of Gibraltar, where fissures nearly three hundred feet decp occur, filled with breccia simHar to that already described. In the case of Gibraltar. itrong ahditional support to Protessor Prestwich's opinion is given by consideration of the smallness of the area at the top of the rock. The animals found in the fissures on Cribraltar are nearly the same as those enumerated at Santenay. It is in the highest degree improbable that all these various wild animals could have at any time or habitually lived toesether on the rock. 


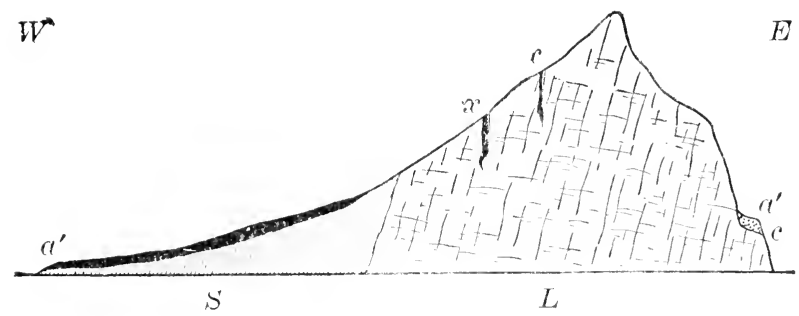

Tranverse Section of the Rock of Gibraltar.

a. limestone breccia, or rubhle drift; $L$, limestone; $S$, shale; $x$, onsiferous fissures; craised beach. "The well-known Rock is an isolated hill, separated from the mainland by a few miles of Hat ground about ten feet above the sea-level, and is composed of hard limestones of Jurassic age, forming a high, scraggy ridge, rather more than two and a half miles long, from 550 to 1,550 yards broad, and rising at the north end to the height of $\mathrm{I}, 3+$ ) feet. . The Rock has been extensively faulted and firsured. Large rent., some perpendicular, and nthers inclined at various angles, and extending to great depths, travere it in different directions. They are met with at all heights up to I, Ino feet." (ine fissure is 290 feet deep, and mother 288 . In mie of thene, at a depth of fifty-three feet, the workmen fisund, in red breccia, two teeth of rhinoceros, a human molar tooth which had never been cut, together with a flint knife, and numerous large pieces of flint. 
$20+$ Evidences of a Deluge in Europe.

"The crags and caves may have been the resort of hyænas and other predaceous animals, but the deer, and other ruminants, the remains of which were numerous, could never have lived in the neighborhood of these carnivora. They would naturally have frequented the surrounding plains and forests, where they could have found food, shelter, and water, rather than scragsdry and in great part barren. It is true that the predaceous animals might have carried there some portions of their prey, but had they done so, either the bones would have been devoured, or such as remained must inevitably have shown marks of the animals' teeth.

"In the second place, no animal remains left on the surface could possibly have escaped destruction in the proximity of ground frequented by hyænas and other carnivora; or, supposing any bones had escaped, they would have decayed under ordinary atmospheric agencies, and exhibited more or less weathering; had they also been washed down by streams and amongst rocks, they would have been rolled and worn. But there is no evidence of weathering or wear, nor is it shown that the fissures are connected with old watercourses. The bones have clear and sharp fractured edges. Only in two instances it is mentioned that the bones present the appearance of being weathered and sun-cracked, and this seems to refer to those found with human remains and works of art, and not to the older breccia.

"For these reasons I think this explanation cannot be accepted, and would again revert to the hypothesis of a submergence of the land. This affords a vera causa 
for the association of animals otherwise so little likely to be found together. It could only have been, as in the cases I have before named, a great and common danger, such as that of the gradual encroachment of the sea on the land, that could have so paralyzed their natural instincts as to have driven those various animals to flock together in search of a common place of refuge from a catastrophe which threatened all alike. Under such circumstances the ruminants would naturally flee from the plain to the higher hills, and when these were isolated, as in this and the other cases I have named, whenever the waters rose above those hills, they were drowned and their limbs dispersed in the manner I have before described."

We have room for but one more illustration upon this point. Near Palermo, upon the island of Sicily, there is an ossiferous breccia of a very remarkable and unique character, containing an enormous number of hippopotamus bones, which are so fresh that they are cut into ornaments and polished, and when burnt give cut ammoniacal vapor. More than twenty tons of bones were shipped from this one place for commercial purposes in the first six months after their discovery. The bones were mostly those of hippopotami, with a few only of deer, ox, and elephant. They belong to animals of all ages down to the foctus. The bones of the various animals were mixed together without order, 


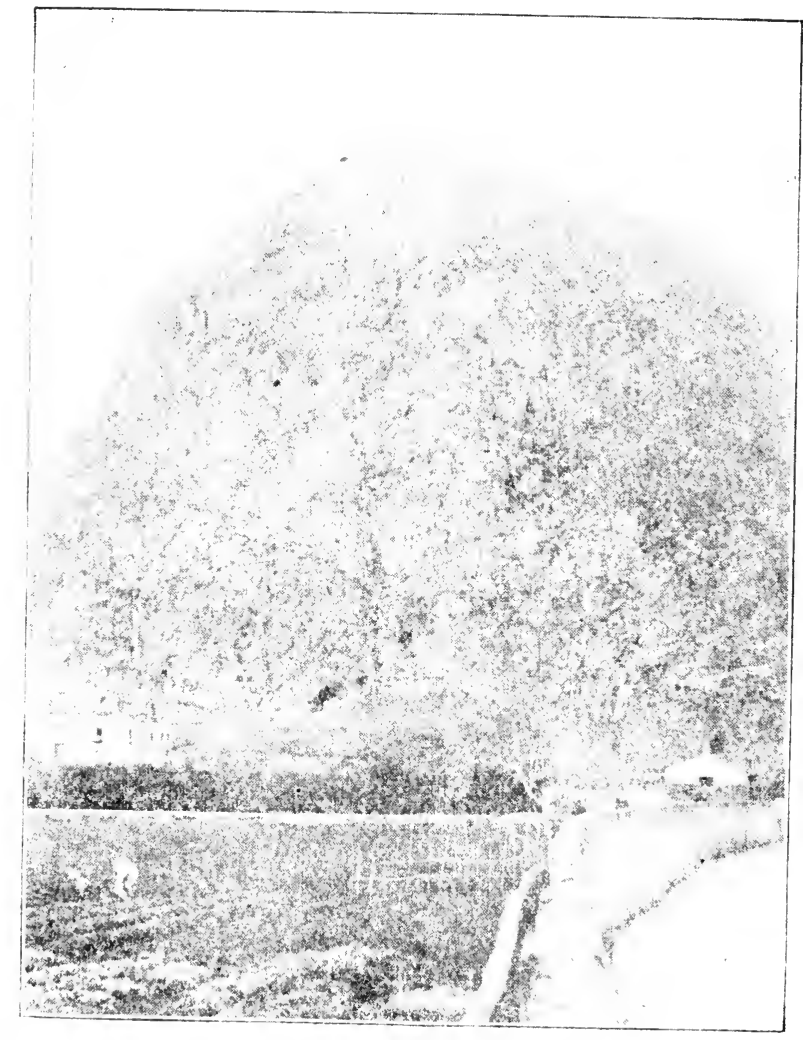

Mouth of the Cave of Ban ('iro, near Palermo.

Photograph hy Frederick B. Wright.) 
and were broken, scattered, and dispersed in fragments, and none of them bore marks of gnawing. The cavern is at San Ciro, about two miles from Palermo, and is at the base of the remarkable amphitheater of hills surrounding the plain on all sides, except towards the sea. The hills are from two thousand to four thousand feet in height. The amphitheater is from two to four miles in diameter, and the elevation of the rock shelter is about two hundred feet above the sea.

"The circumstances, therefore, which led to these remarkable accumulations of the remains of the hippopotami must have becn extraordinary, and I see no hypothesis which meets the case, so well as the one that I have sugrgested to account for the bones of mammalia in the rubble drift and in the ossiferous fissures, though the local conditions in this case are peculiar.

"On the submergence of the Sicilian area, the wild animals of the plains would, as in the case of Santenay, Cette, and Gibraltar, be driven to seck refuge on the nearest adjacent high ground and hills. In the instance before us, the animals must have fled to the amphitheater of hills which encircle the plain of Palermo on all sides except the sea, and on the slopes of which the Cave of San Ciro and the others are located. As the waters rose, the area of this plain became more and more circumscribed, and retreat more and more imposible, except through a few rare passes in the range of hills, until, at last, the animals were driven together at the 
base of the hills, where they were stopped by mural precipices impassable to the larger and heavier animals, though some of the more active and agile ruminants and carnivores may have, and, judging by the rarity of their remains, probably did escape to the mountains behind. Retreat entirely cut off by projecting promontories on either side, the only paths yet open to the imprisoned herds were those that led to the caves, which were a little above the general level of the plain. Hither the animals must have thronged in vast multitudes, crushing into the caves and swarming over the ground at their entrance, where they were eventually overtaken by the waters and destroyed, and, as their bodies decayed, a confused mass of their remains were left and scattered on or near the spot where they finally congregated.

"For reasons before given, the land could not have remained long submerged. As it rose intermittently from beneath the waters, our supposition is that the rocky débris on the sides of the hills was hurled down by the effluent waters on to the piles of bones below, breaking them into fragments, and forming, together with them, the heterogeneous mass of bones and rubble constituting the breccia. The last more rapid uplift, the effects of which are so frequently seen in many sections of the 'head,' brought down the larger blocks of rock that now lie on the top of the whole. Scinà, an independent witness, inferred from the character of the rock fragments, and from the red clay in which they are imbedded-and which comes from decomposed 


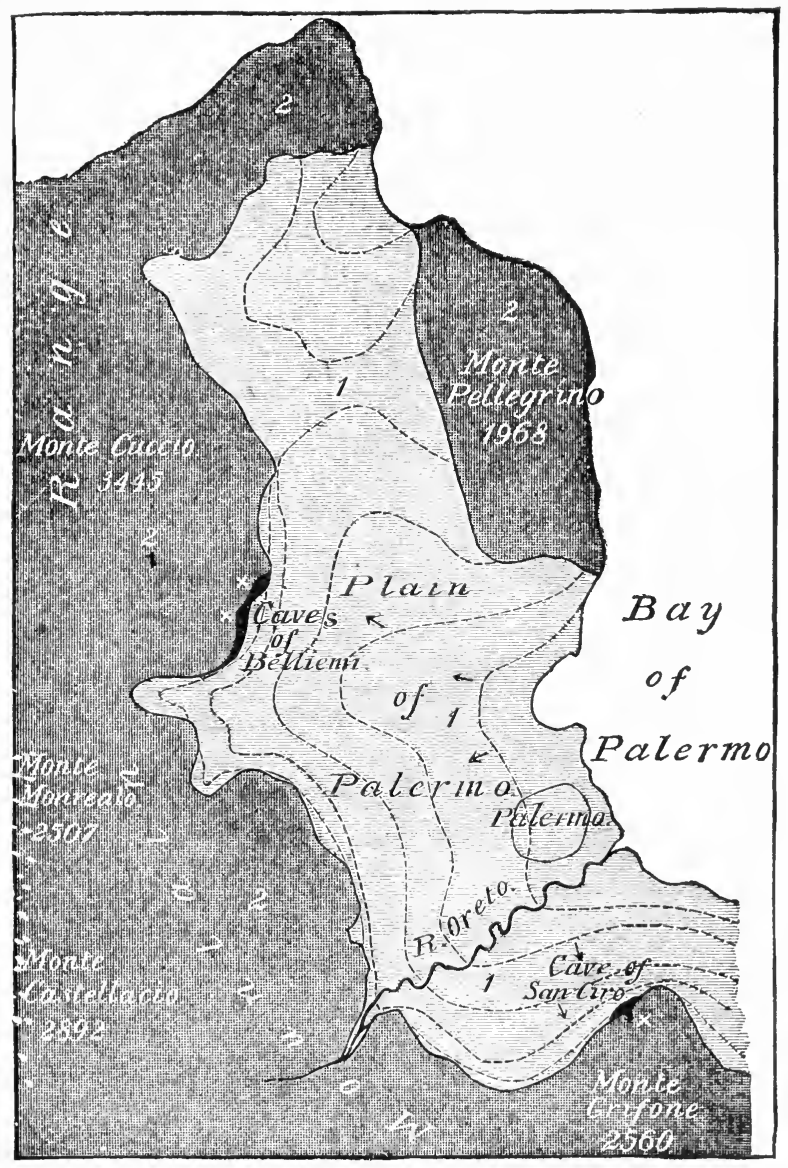


rock surfaces on the hills above-that, in the case of the Belliemi breccia, both the detritus and the bones had been washed down from Monte Belliemi. All this must have been effected in a space of time comparatively so short, that, though the bodies of the animals decayed, the bones underwent but little change, nor, encased as they becane in an almost impermeable breccia, has the change they have since undergone been great.

"Thus there is, in all the essential conditions, a close agreement between this Sicilian breccia and the rubble drift of the south of England, as likewise with the rubble on the slopes of Mount Genay, of the Rock of Gibraltar, and of other places mentioned in the preceding pages. In all, the débris consists strictly of local materials; the fragments are angular and sharp; the bones are mostly in fragments, and are neither gnawed nor worn; and the faunal remains are those alone of a land surface, and of species such as then were to be found in the district. 'This rubble, also, forms in all these cases the last of the drift beds. The only apparent difference arises from the circumstance that, in the Sicilian area, the geographical configuration was that of a land-locked bay with many minor bays or embrasures in the front of the hill-range, so that, as the waters rose, the animals of the plain were driven together, as in a seine, into those bays, where, as a last resource, they sought shelter under the mural precipices and in the more accessible caves. As these precipices were nearly vertical, they formed, as the land rose again, a partial protection from the effluent currents, 
which otherwise might have carried the débris to a greater distance outwards. Under no other circumstance that I can conceive could the animal remains have been massed as they are at the foot of the escarpments encircling the plain of Palermo.

"It may be asked how could large herds of hippopotami have existed in so limited a plain as that of Pálermo. It needed then to have had much greater extent and larger rivers. I have shown that the present height of the raised beaches on the English coast does not give the initial upheaval, but is the sum of the differences of several earth-movements-that the primary upheaval of the beaches was not less than one hundred to one hundred and fifty feet greater than the altitude at which they now stand, and that this led to the conversion of a considerable extent of the area of the Bristol and English Channels into dry land. What little evidence we have on the coast of Malta, and of Greece, points to similar elevations of the coasts of the Mediterranean, so that large tracts of dry land may then have existed between the Sicilian and Italian shores, and formed suitable pasture grounds for the hippopotami. With increase of the land area, so would the rivers also have had increased size, and though they may not have been very large, yet as Sir S. Baker has shown, perennial waters are not indispensable to the hippopotamus, for in the Settite and other rivers of the Soudan, those huge animals tide over the dry season, by resorting to the few pools left in the dried-up channels of the rivers." 
Not to pause longer upon the numerous other facts collected by Professor Prestwich bearing upon this point, we turn finally to select one from his many illustrations drawn from-

3. The Loess Deposits of Europe.-It is well, however, to call the attention of the reader to the fact that the origin of the loess is one of the most difficult problems which geologists have to consider, and that here, as in the other evidence, it is the wide experience and great skill of Professor Prestwich which have enabled him clearly to see the bearing of the facts presented. For evidently the loess has been distributed by a variety of agencies. It is only in special conditions that its occurrence can have the significance which Professor Prestwich assigns to it in the instances adduced by him.

Loess is a very fine superficial loam which is usually devoid of any intermixture of sand or gravel, or indeed of any grit, and without any remains of marine and rarely of fluviatile shells. It can be easily crushed in the hand to an almost impalpable powder, yet its consistency is such that it will support itself many years in vertical cliffs a hundred feet and more in height. In St. Joseph, Mo., I have seen on a perpendicular cliff of loess the fresh imprints of the shovel used to cut a roadway fifty years before. In China I have 
traveled for miles between perpendicular walls of loess fifty feet in height through a road worn by centuries of travel. It is so porous that the rainfall all percolates to the bottom, so that no springs appear except at its base; and yet, on account of capillary attraction, it is never wholly free from moisture. In composition it is nearly pure silica, or sand, with a little carbonate of lime. This usually fills innumerable tubular pores which penetrate the mass, and give it both its consistency and its internal vertical structure, causing it to preserve a perpendicular face wherever it is excavated. Its characteristics are unmistakable, and are identical the world over.

Along the Missouri River from Kansas City far up into Dakota, loess forms the lining bluffs of the valley, having a depth of more than a hundred feet. Large areas in Russia, China and Central Asia are covered with it to even greater depths, while its occurrence along the valley of the Rhine accounts for the German name by which it is ordinarily designated.

The anomalous facts connected with its distribution have greatly puzzled geologists. The material is so fine that it is readily blown about hither and thither by the wind, so that Baron Richthofen and others maintain that the loess of China is but the accumulated dust which the westerly winds have brought over from the 
parched and elevated plains of Mongolia and Tibet. The definite relation, however, of the deposits to water-levels in the valleys of the Mississippi and the Rhine makes it certain that in many areas these are water deposits. Still, the facts are so complicated that Geikie and others think it necessary in Central Europe to bring in both wind and water to account for its distribution. In the glaciated regions both of Europe and America many anomalous local deposits of loess can be readily accounted for by the action of water held in place by ice during the retreat of the continental glacier. No doubt the greater part of the arguments for the Flood drawn from the loess by Sir Henry Howorth and others are explained by fuller knowledge of the irregularities produced by the slowly melting ice-sheet which covered the northern parts of the continents of Europe and America. But the facts adduced by Professor Prestwich have been carefully selected with reference to this danger of error, and strongly confirm the other evidence pointing so strongly to the occurrence of a recent catastrophe in Western Europe closely analogous to that described in the biblical account of Noah's Flood. A single one of the facts under this head must suffice. A fuller discussion of some phases of the subject is naturally deferred to later chapters, which treat of its distribution in Asia and America. 
The Channel Islands of Guernsey and Jersey are surrounded by a raised beach which is overlaid by rubble drift such as was described under that head. The greater part of the island of Guernsey, however, consists of a plateau of granitic rocks from three hundred to three hundred and fifty feet above sea-level, but without any commanding heights. The plateau is covered very generally by a deposit of loess or brick-earth, from five to ten feet thick, extending over the highest points of the surface. In character this is identical with that on the mainland.

It is not possible to account for this deposit of loess on any of the theories which are limited to river floods, glacial inundations, or rain wash as the distributing agencies; for-

"there are no rivers in either island, and the watercourses are mere small brooks thai could scarcely flood the lowest ground, and certainly could never, in present nor past times, have reached the plateau on which the loess occurs. Nor are there any hills, rising above the general level of the plateaus, the wash from which could have been spread over those plateaus. Nor can it be admitted that it was formed when the island was connected with the mainland, and that the loess is due to the extension of the land flood-waters, over what was then part of the continental area; for, unless the loess were older than the raised beaches, it is obvious, as 
270 Evidences of a Deluge in Europe.

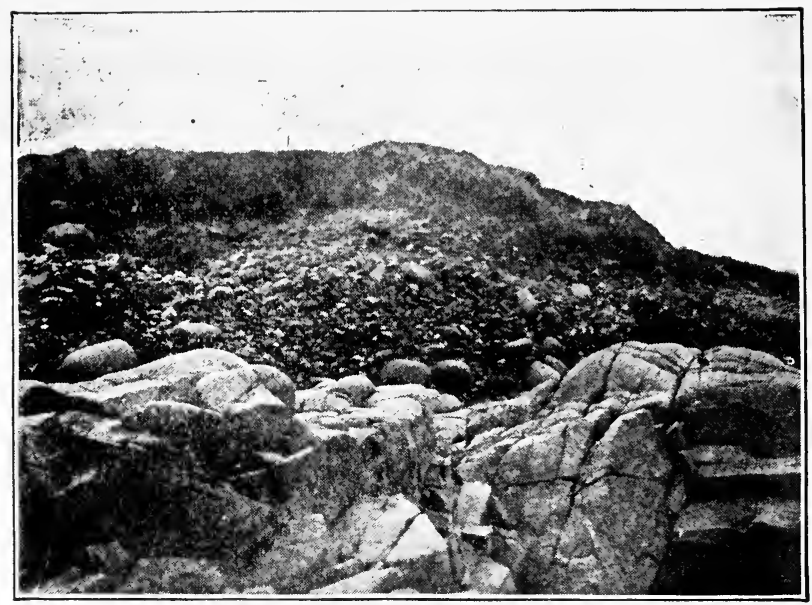

Raised Beach on the Island of Guernsey.

Similar beaches appear at various points around both the island of Guernsey and of Jersey. But, as will be seen by the illustrations on pages 278 and 279 , the accumulation of rubble drift is naturally less than it is on the mainland, where the elevations in the interior are higher and more extensive. It is plain that the covering of rubble drift could not have been brought into place by local currents of water, since there is no chance for the origin of such streams, and the rubble drift overlies the raised beaches on every side of the islands. (Photograph by Mr. J. E. L. Miller.) 
those beaches extended all round the islands, that at the time of the deposition of the loess, the islands were then, as now, detached from the mainland. The loess, in fact, is closely connected with the 'head,' and not infrequently associated with it. A thin layer of an angular rubble similar to that which forms the 'head,' is also often to be found at the base of the loess, and as the rubble is newer than the beaches, so must the loess likewise be newer, and subsequent therefore to the severance of the islands from the mainland.

". . . . that a uniform sediment of that character should be formed during such a submergence as we have described, is, owing to the waste of the softer surface beds and decomposed rocks by the advancing waters, what we might expect. This waste was general over all the area submerged, and the waters must have been rendered turbid to a considerable distance from the coast (on the coast of China the sea is colored yellow to a distance of one hundred miles from land by the fine loess-mud carried down by the rivers), so that not only the mainland but the adjacent islands also were covered with a mantle of sedimentary matter deposited during those periods of comparative quiet or lulls, which are shown to have occurred in the formation of the 'head.' The absence of marine remains is readily accounted for by the temporary nature of the occupation of the land by the sea waters, as well as by the circumstance that the waters would be rendered for a time unfit for the habitation of marine life. ...

"If we suppose that the loess in these islands was 
deposited during and after submergence, it follows that as the land rose, it would be removed where it was in the way of the effluent currents, and carried with the angular rubble down to lower levels, or to a distance. That this was the case is shown by the fact that the 'head,' which covers the beaches, consists of angular local rubble, with loess or brick-earth (derived from the plateaus) as a matrix and forming occasional seams and overlying beds. The following diagram will illustrate my meaning."

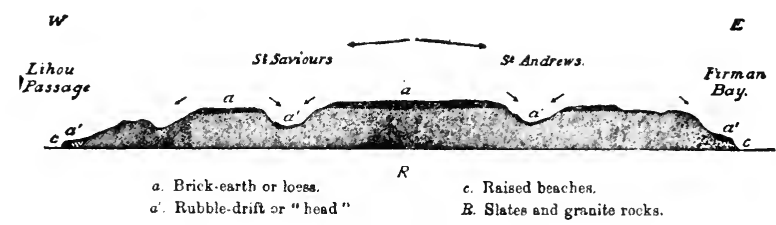

Diagram Section across the Island of Guernsey.

"One feature that I failed to notice in Guernsey occurs in marked distinctness in Jersey. This is the distance to which the 'head' has been propelled from its base. The section at the islet of La Motte is especially illustrative of this fact. . . This islet lies one and one-half miles southeast of St. Heliers, on a part of the coast where the shore is low, but rising gradually inland to a height, at Mont Ubé, of one hundred and forty-nine, and at Prince's Tower, two and one-half miles inland, of two hundred feet. A rubble drift descends the slopes of Mont Ubé and St. Clements ( 160 feet) and forms a small low cliff on the coast, 
while at the distance of about one thousand feet from the shore, and accessible at low water, is the small, flat islet of La Motte. It is only a few acres in extent, and consists of a base of diorite, capped by the remains of an old beach, overlaid by a mass of rubble drift.'

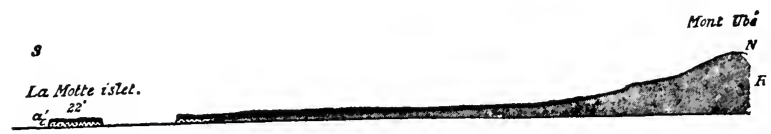

Section from La Motte to Ubé.

$a$, rubble drift, composed of granite and diorite débris, in a brick earth, or loess, covered by a sandy earth and soil. $c$, raised beach, only portions of which remain.

"The syenite and diorite fragments in the rubble are derived from the hills of the adjacent coast, while the brick-earth which caps those hills forms the chief portion of the rubble matrix. Notwithstanding the slight difference of level and the very small gradient of the slope from the inland hills to La Motte, a considerable spread of rubble drift has been propelled thus far out, which, I conceive, could only have been effected by a strong effluent current, passing from the mainland seaward during the upheaval of the land. The hills are so low and distant that no snow-slide could possibly have effected this transport."

"The phenomena, however, are readily explicable on the assumption that, as with the 'head' at Brighton and Sangatte, the driving force was that of a superincumbent body of water, flowing outwards. As at Sangatte, the forcible impact of the 'head' on the 
beach has led to the incorporation of fragments of the beach in the 'head.'."

After giving further evidence that this loess must "have an origin independent of those to which it is ordinarily assigned," and presenting similar evidence in a large number of other cases both among the Channel Islands and over widely spread portions of the Continent, Professor Prestwich states the probable method of accumulation as follows :-

"I am well aware that several objections, more or less formidable, may be raised to the hypothesis which I have suggested to account for the origin of this drift. A few of these I may allude to here, though it would not be possible to discuss in these pages the wide and important general questions involved. Those who hold uniformitarian views will object to the want of known precedents and to the exceptional character of the agency proposed. In this difficulty I cannot share. I must repeat what I have long contended for, that it is impossible to suppose that our very limited experience - say of two thousand years-could furnish us with standards applicable to the comparatively illimitable past. In fact, those that are relied on depend upon unstable conditions and are liable to vary with every passing century. While admitting the permanence of the laws of nature, it is impossible, under the conditions through which this globe has passed, to suppose that at all former periods the effects, which have resulted from 
the operation of those laws, though equal in kind, were equal in degree. As in other similar questions, we must judge of the hypothesis not by an à priori assumption, but by the agreement of the consequences which it involves with the facts, and by the extent to which it satisfies the various conditions of the problem."

"Whatever phase of the rubble drift we may examine, we recognize in all of them physical and faunal conditions referable to the agency of one and the same cause. Whether we look at (1) the débris in one section of the loess, (2) the breccia on slopes, (3) the ' head' over the raised beaches, (4) the basement gravels of many valleys, or (5) the ossiferous fissures, we discern a complete absence of that wear which results from maintained river, sea, or ice action. Nor is there any indication of that transport of débris from a distance which attends river or tidal action. On the contrary, all the component materials are of local origin, derived from the adjacent slopes or hills, and they are ali unworn. The evidence of the organic remains is to the same effect, in that they are those of a land fauna alone, with an entire absence of marine and fluviatile remains. The bones found in the rubble drift are not only in the same unworn condition as the rock fragments, but they are free from all marks of gnawing. This is a proof that the animals had not, as in the caves, fallen a prey to carnivora, but must have met their death in a way which was unusual-such as from drowning-for had their bodies remained on a land surface after death, they would have been subject 
to being devoured by predaceous animals, or else the bones would have shown traces of weathering and wear. At the same time the sharply fractured state and dispersion of the bones show that they must have been subjected to considerable violence and displacement. These conditions, as well as the mode of distribution of the rubble from many independent centers, accord in all points with the results that would ensue from the submergence and reëlevation of a land surface from beneath deep waters after a temporary submergence.

"These conclusions, startling though they may appear, have been forced upon me, not only by my own observations in the South of England, and parts of the Continent, but also by the independent evidence of other geologists, though their interpretation of the facts may be different. Looked at in all its aspects, I see no alternative that equally well answers to all the conditions of the problem. Other explanations may satisfy some of the conditions in particular cases, but none of them satisfy all, whereas I think it will be found that the submergence hypothesis not only meets the requirements of each particular case, but that it also shows them all to be concordant, and such as would pertain to one common and general cause." 


\section{CHAPTER $\mathrm{X}$.}

\section{EVIDENCE OF A DELUGE IN ASIA.}

THE summary in the preceding chapter by Professor Prestwich is limited to the facts connected with Western Europe and the Mediterranean basin. How far this subsidence of which he finds evidence may have extended in a more northeasterly direction he does not venture to say, because of the lack of evidence.

It was partly to supply this lack that, at the beginning of 1900 , in company with Mr. Frederick B. Wright, I set out on a zigzag journey across Asia, through China, Mongolia, Manchuria, Siberia, Turkestan, Asia Minor, Trans-Caucasia, Russia, Syria, Palestine, and Eggpt ; and that again, in 1905, with the same end in view, I visited, in company with Mrs. Wright, England, Denmark, Sweden, Southern Russia, the Crimea, and revisited the Lebanon Mountains and Northern Egypt. ${ }^{1}$

The first expedition was undertaken in the expectation of finding in Eastern and Northern Asia signs of the occupation of those regions by glacial ice similar to those which exist so abundantly in corresponding lati- 
tudes in North America. But in this we were disappointed. While the ice of the Glacial epoch extended in the United States in an unbroken sheet to the latitude of New York City, on the Atlantic coast, and to the southern part of Illinois, in latitude $38^{\circ}$, in the Mississippi Valley, there was evidently no general occupation of Siberia by glacial ice south of the fifty-sixth degree of latitude. But in place of glacial phenomena we found evidence of a recent depression of the area, amounting to somewhere from two thousand to three thousand feet. This evidence largely consists in the distribution of loess over China, Central Asia, and Southern Russia. It is necessary, therefore, to give the facts somewhat in detail.

All the rivers of Northern China are densely loaded with sediment derived from the loess-covered areas through which they pass in the upper portion of their courses. In this respect they much resemble the Missouri. The vast plain of the Hoangho, in Northeastern China, consists essentially of this sediment, which has been deposited gradually by the river. The river in the lower part of its course now occupies a channel raised considerably above the great mass of the plain, which stretches away on either side. It is owing to this position of the river that periodical floods so often devastate the interior, and that the mouth of the Hoang- 
ho is subject to such variation. The river now empties into the Gulf of Pechili, about 150 miles south of Tientsin, but not long ago it wandered over the southern plain and joined the Yangtsekiang 150 miles above Shanghai, 400 miles south of its present outlet. On the other hand, at the present time, during extreme floods, portions of the water turn off to the north, near Kaifun, and, after a course of 350 miles, join the Peiho at Tientsin. Indeed, this most fertile portion of the Chinese Empire is a broad delta of modified loess deposited by the Hoangho, its base extending from Tientsin to Shanghai, a distance of 600 miles, with its apex 300 miles inland.

A general impression of the rapidity with which thie denudation of the loess is proceeding may be formed by noticing the extent of very muddy water which borders the whole Chinese shore of the Yellow Sea. When forty miles out from Shanghai, the traveler encounters a sharply cut line, which can be distinctly seen for a long distance in either direction, separating the clear water of the ocean from the turbid, opacue, silt-laden water brought down by the great Chinese rivers. It is thus evident that deposition of loess is now taking place with great rapidity all along the Chinese side of the Yellow Sea.

This is further shown by the extensive shoals and 
sand-banks which extend from Shanghai nearly to the Shantung peninsula. They mark an extension of the combined delta of the Hoangho and of the Yangtsekiang, as the former has from time to time turned its flood in that direction; but the historical record of the growth of land on the Gulf of Pechili is still more convincing of the activity of this transporting influence. Pao-to, on the Peiho River, was near the shore 200 в.c. It is now forty miles inland. During the Han dynasty, Tientsin was a seaport. Now it is thirty miles inland. As late as 500 A.D., the sea was eighteen miles nearer Tientsin that it is at the present time, while the increasing difficulty experienced by ships in approaching the harbor of Taku, at the mouth of the Peiho, is confirmatory evidence of the rapidity of this sedimentation. The records show that all along the shore of the Gulf of Pechili the land for the last two thousand years has been gaining on the sea at the rate of about one hundred feet per annum. These facts need to be borne in mind when considering the date of the period of the accumulation of the loess over the interior region penetrated by these Chinese rivers.

LOESS ON THE BORDER OF THE PLAIN OF PEKING.

Peking is situated near the northeastern extremity of that broad belt of modified loess stretching out on 
either side from the Hoangho which we have been describing, and is about thirty miles from the bordering mountains, which limit the plain on the northwest, and about eighty miles inland from the sea. From near the border of the mountains to the sea through Peking the slope of the surface is pretty uniform, averaging about six feet to the mile, so that the surface of the loess at the entrance to the pass at Nankau is about six hundred feet above tide. The slope from Peking to Nankau, however, is considerably greater that it is on the other side toward the sea. Issuing from the pass at Nankau; a very distinct delta extends out on the plain for a distance of between five and six miles. This delta consists of a rather confused intermingling of loess with sand, and gravel, and occasional fragments of rock a foot or two in diameter. This coarser material occurs near the surface as much as four miles outside the mouth of the gorge, the surface sloping to that distance in a direct line at the rate of fifty feet a mile, making two hundred feet in the first four miles; but on the southwest side the descent is abrupt, leaving a long low plain several miles wide between the delta and the mountains in that direction.

On the contrary, on the northeastern side the deposits of loess, at nearly the same level with the head of the delta, stretch for many miles along the base of the 


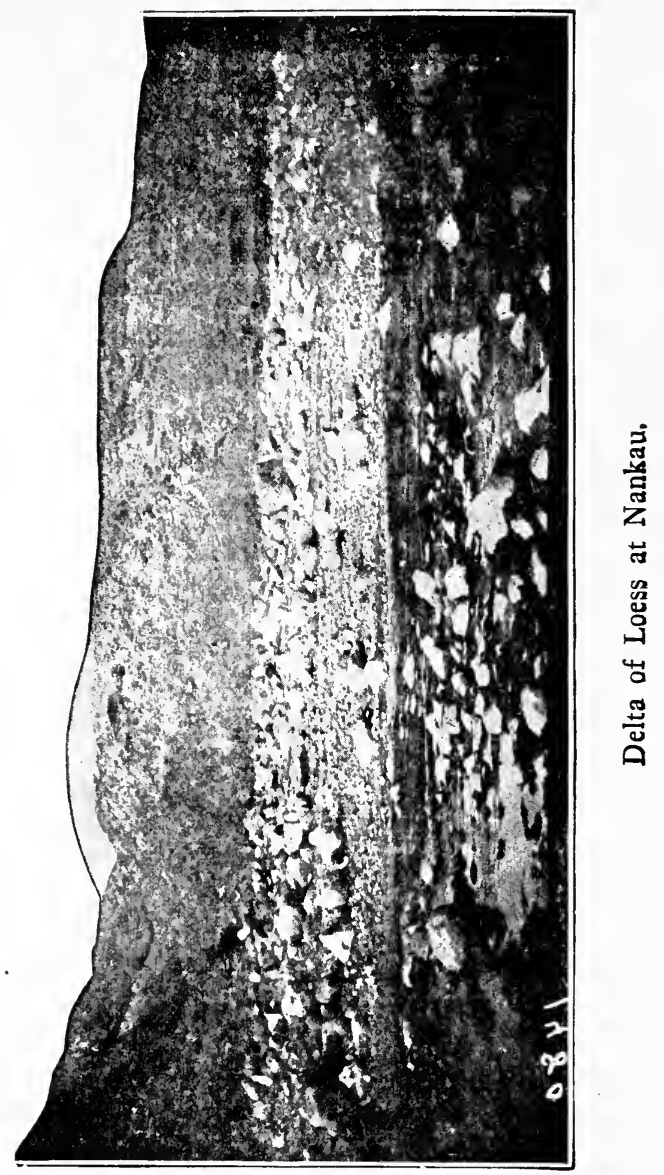


mountains toward the Ming tombs. In many places here we passed between perpendicular sections of loess fifteen to twenty feet in height. They were especially prominent in the vicinity of a small stream coming down from the mountains about half way between Nankau pass and the Ming tombs, a distance of about ten miles; but the larger stream coming down from the mountains into the amphitheater around which the Ming tombs are built has worn a broad deep channel in the sedimentary deposits, and occupies a bed fifty or more feet below the general level. This bed is thickly strewn with boulders several miles away from the base of the mountain. The portion of one of these boulders projecting out of the ground measured $9 \times 6 \times 3$ feet.

From the situation of these deposits, it is clear that they sustain a definite relation to the comparatively small streams coming down into the plain from the mountains to the northwest. Of these the Bishaho, which comes through Nankau pass, is the largest. Evidently, at the time of the deposit of the deltas, waterlevel was met at the base of the mountains at the elevation of six hundred feet, which is that of the head of the delta spreading out from. the Nankau pass. It seems also clear that, at the time of the main deposition, the material to which the stream had access was much 


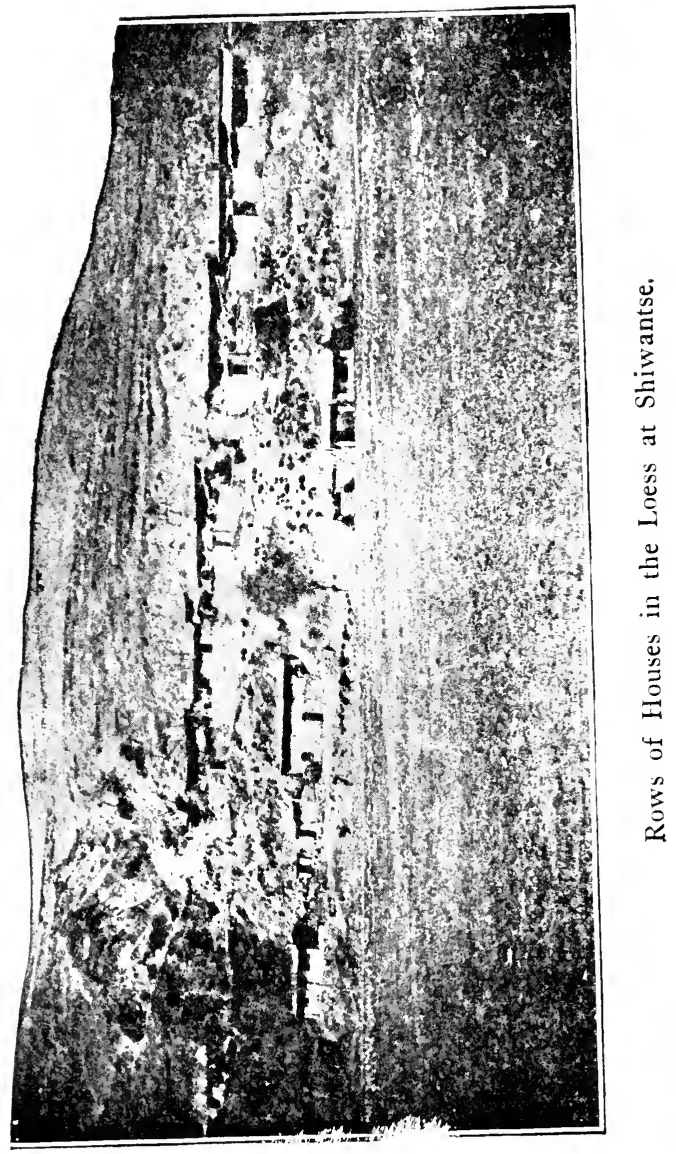


more abundant than it is now, for at the present time all these streams are rapidly eroding material at these higher levels and transporting it to lower levels. The Bishaho, having completely abandoned the line of its old delta, now turns off to the south, to meander along the low plain intervening between it and the mountains in that direction at a level two hundred feet lower than its former bed.

In one of these valleys, near the Mongolian escarpment, there was especially clear evidence of the recent cessation of the agencies which had been distributing the loess in its normal quantities. This was two miles above Hanchinbah, in the first stream east of the escarpment, running southwest between mountain ranges about two thousand feet higher than the valley. Here is a bluff of loess about forty feet in height, and extending back from the stream in a well-defined terrace for a considerable distance, yet it was exposed to the direct force of the stream in a concave bend with its unprotected perpendicular face to the stream. The stream bore every mark of being at times torrential, its bed being full of large boulders, some from four to five feet in diameter, all in slow process of transportation down the stream. The gradient of the stream here was between one hundred and two hundred feet per mile. That so large an expanse of loess should have been 
accumulated to such an extent by present agencies, or should have remained in this unprotected position for many thousand years, would seem extremely improbable, not to say impossible.

WIND AND WATER COMBINED AS DISTRIBUTING AGENCIES.

Baron Richthofen, in his great work on "China," maintained that the source of the Chinese loess was to be found in the desiccated area of Central Mongolia now occupied by the Desert of Gobi. Here, during long ages, the superficial rocks, according to him, have been slowly disintegrating under the conditions of an exceedingly dry climate, accompanied with great alternations of heat and cold, while the wind has been constantly transporting it in clouds of dust toward the eastern and northeastern borders, where it has been detained in excessive quantity in the moister climate of the mountain valleys lying east of the Mongolian escarpment.

But it seems necessary, from the facts above presented, to believe that its present distribution over Northeastern China was mainly secured by the agency of gradually receding water, the presence of which would be obtained by a temporary general depression of the land, amounting at any rate to several hundred feet. 
Over much of the space bordering on Mongolia, the loess has accumulated in level areas which resemble lake-basins. In many cases these are without outlet, and contain remnants of larger bodies of water, which are now drying up, leaving well-marked terraces at elevations of considerable height around the rim. In many of these level areas of loess within the drainage basin of the Yangho, there are numerous deep narrow ravines, with branching tributaries, cut to a depth of one hundred feet or more by retrograding erosion, the loess standing in perpendicular faces on either side. Pumpelly describes one of these chasms as "more than seventy-five feet deep, with a width of only four feet between vertical walls of loam, and winding in a a crooked course for more than a mile." In many places, especially near the bordering ledges of rock and near the center of the larger valleys occupied by the main stream, there are distinct lines of coarse gravel and rocky fragments interstratified with the loess. This oftentimes continues for a long distance over a comparatively level area, where it would seem impossible for superficial currents from local cloudbursts to have produced the results.

On the other hand, it was noticed that in the narrower valleys, running east from Kalgan to Shiwantse, between the lofty border of the Mongolian plateau and 


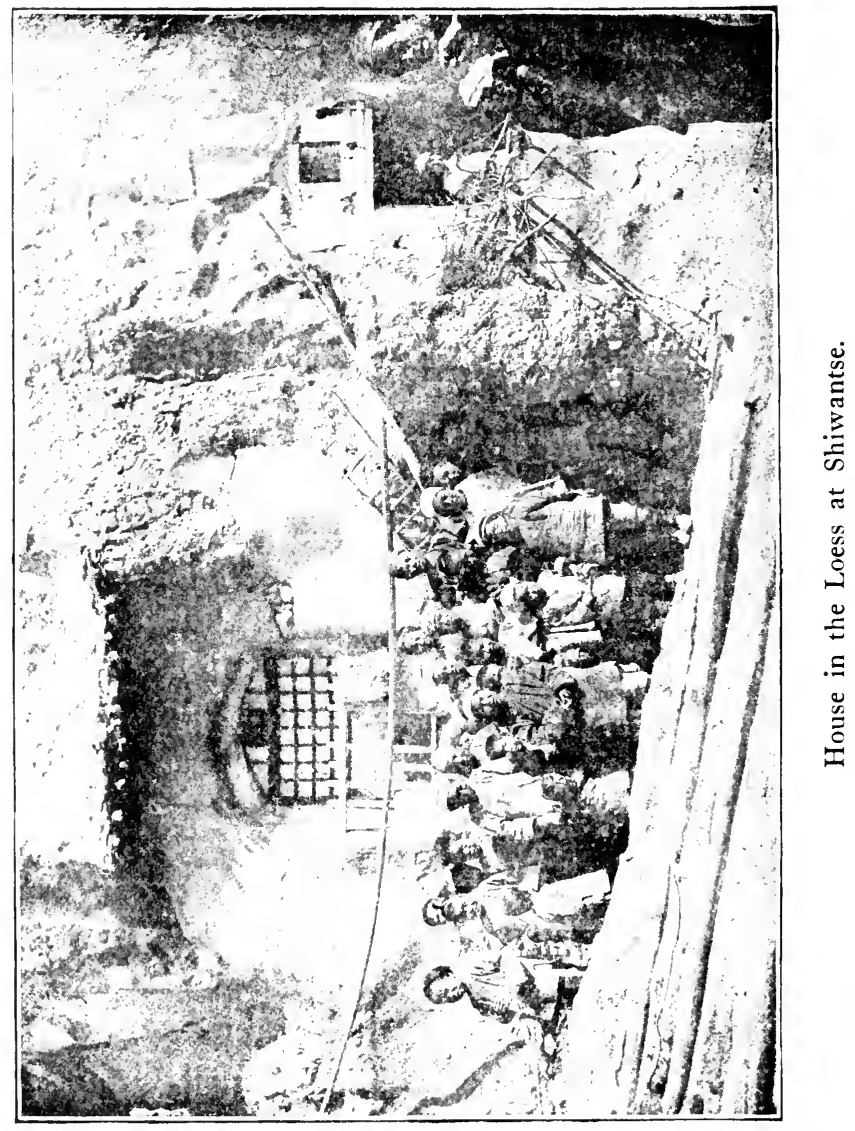


the nearest border range, there were numerous and extensive deposits of loess that had been very clearly drifted in by the wind. The resemblance of these deposits to immense snowdrifts accumulating on the lee side of the mountains was very striking. This was especially the case at Shiwantse, where the entire village of 1,500 or 2,000 inhabitants finds shelter in commodious and comfortable houses dug into the hillside of loess which flanks the eastern face of the mountain range. These houses are excavated in successive receding stories one above the other, the natural roof of one house serving as the front yard of the house above it. These dwellings extend for three hundred feet or more up the slope of the loess, which continues upward for a considerably greater distance. In this valley we saw many such villages, and in crossing the mountain from west to east found extensive drifts of the loess up to a height of 5,000 feet above the sea. But the greater accumulations of loess were below a level of 3,000 or 3,500 feet above the sea, and in many cases, even on the margins of the larger and deeper valleys, were spread out in such extensive and level areas as to suggest a terrace deposit near the margin of standing water. It became increasingly difficult for us to believe that wind could have distributed the material with such an even 


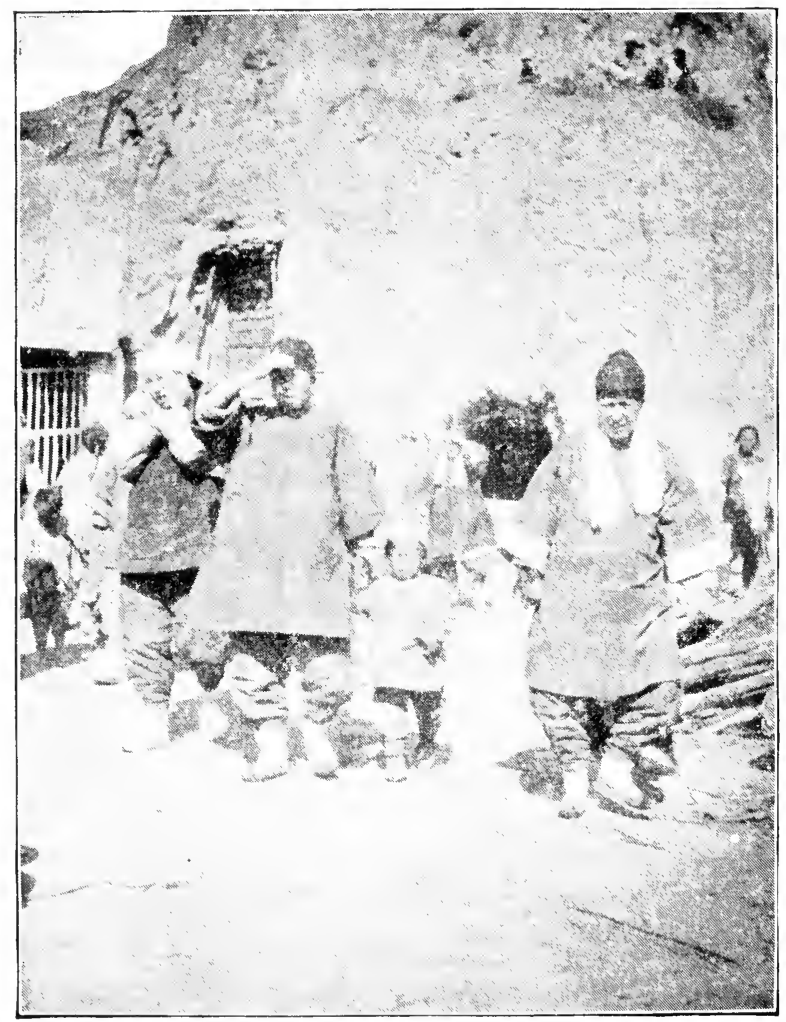

Another House at Shiwantse.

This view shows the perpendicular face of the loess in which the excavations are made. The Chinese in these illustrations are Catholic converts. (Photograph by F. B. Wright.) 
surface on the margin of such well-marked and deep valleys as we repeatedly crossed. ${ }^{2}$

But, notwithstanding the lack of glacial marks in Eastern Mongolia, and after making the most of the wind hypothesis for the accumulation of the loess on the Chinese border, the way is still open to maintain that here, as elsewhere, its ultimate origin is glacial. For microscopical examination shows that the particles of loess the world over are of mechanical origin, closely corresponding to the fine sediment which is held in suspension by subglacial streams, which is the result of glacial erosion. Chemical analysis shows, also, that it is not clay, but extremely fine sand, the particles of which average only one-two-hundredth-thousandth of the size of an ordinary grain of sand. Still, even with this small size, the particles of loess will settle in water nine times as quickly as the particles of clay. ${ }^{3}$

The general distribution of loess likewise points to its glacial origin. In the United States it is practically limited to those portions of the Missouri and the Mississippi Valley contiguous to the glaciated area and to the lines of drainage leading from it. Indeed, the largest deposits of loess in the Missouri Valley are definitely referred to the floods accompanying the melting of the lobe of glacial ice whose border extended east and west midway across the State of Iowa. In Europe 
the great deposits of loess are those over the southern plains of Russia, which form the belt of black earth so productive of wheat and other cereals. These Russian deposits are likewise seen to have a definite relation to the great Scandinavian glacier, which extended as far south and east as Kief and Penza. In Central Europe the smaller deposits of loess may easily have been derived from the Alpine glaciers, which were formerly much more extensive than now.

So confident was Professor James Geikie of the glacial origin of the extensive loess deposits of China, that, in the third edition of his "Great Ice Age," he represented upon his map an extensive glaciated region on the borders of Mongolia, near Kalgan. My own personal investigations in 1900 , however, revealed a total absence of the marks of glaciation over that area, as well as orer that of the Vitim plateau east of Lake Baikal, which he had covered with extinct glaciers. If, therefore, the loess of China is of glacial origin, we must look to some more distant source.

It has been suggested to me by Dr. N. O. Holst, of the Swedish Geological Survey, that the glacial origin of the Chinese loess may still be maintained by looking to the high mountains of Central Asia for its source. As is well known, extensive glaciers are found in all the higher altitudes of the Himalaya and Tian Shan 


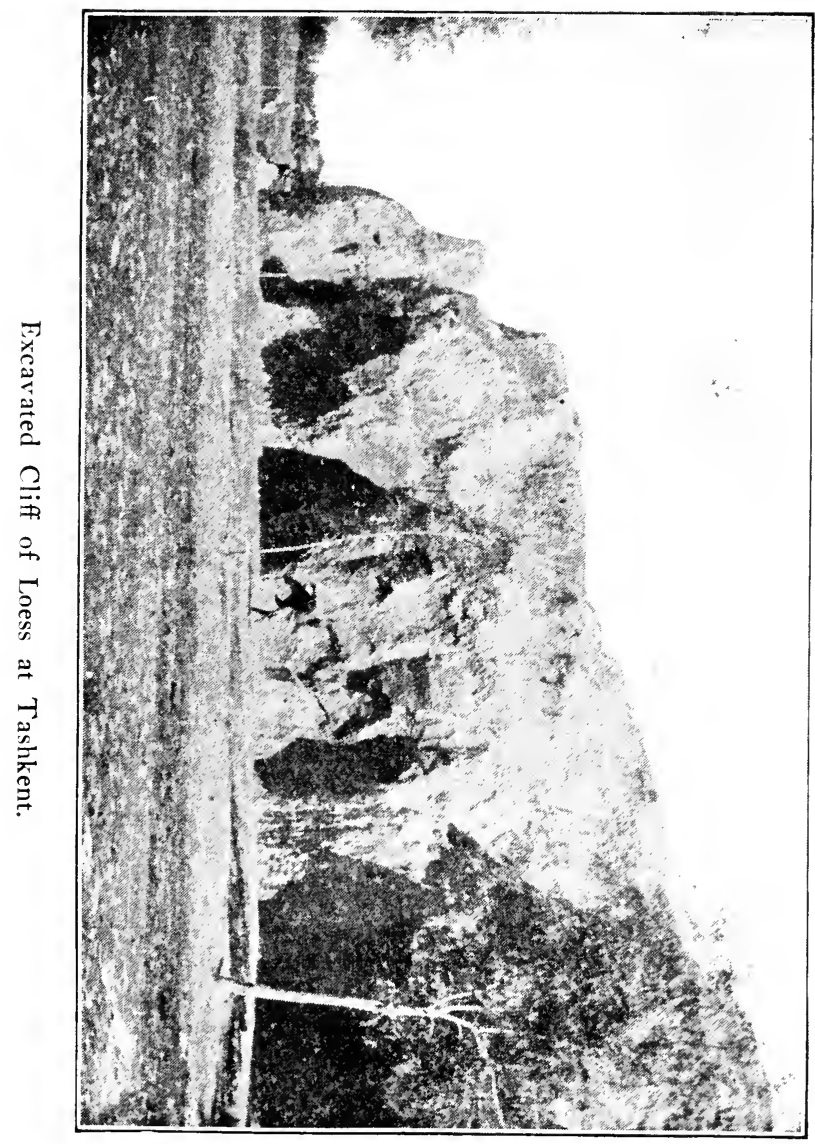


Mountains, but my investigations proved that these Asiatic glaciers never extended down into the plains to anything like the extent with which the Alpine glaciers invaded Switzerland and Northern Italy; for, in a drive of eight hundred miles along the northern base of the Tian Shan Mountains at an elevation of about two thousand feet above sea-level, no moraines whatever were encountered, while, two years later, Professor William M. Davis and Mr. Ellsworth Huntington crossed the Tian Shan Mountains from Kalgan to Verni, and found likewise, by actual observation, that at no time had glaciers extended down the flanks of these mountains below the level of seven thousand feet. Still, loess accumulated to an immense extent about the base of both sides of the range, occurring in specially large amount wherever the streams which head in the glaciers debouch upon the plain.

These facts open the way to regarding the loess of China as having its ultimate origin in the mountains of Central Asia, since it may be the grist which the glacial streams from these high mountains had originally brought down upon the borders of the Gobi Desert, thence to be transported by the prevailing southwesterly winds to the mountainous eastern border of the great Mongolian plateau. Speaking of the wind as a transporting agency, Pumpelly remarks, that 
" no one can realize the capacity of wind as a transporter of fine material who has not lived through at least one great storm on the desert. In such a simoon the atmosphere is filled with a driving mass of dust and sand which hides the country under a mantle of impenetrable darkness and penetrates every fabric; it often destroys life by suffocation and leaves in places a deposit several feet deep. . . The often cited instance of far driven volcanic ashes shows the ability of the wind to carry comparatively coarse dust through distances of several hundred miles, but it does not seem improbable that the finer particles may remain suspended while the wind makes a complete circuit of the globe." 4

In my own experience in Eastern Mongolia I frequently witnessed whirling columns of dust rising like thunderclouds from the earth, and moving onward to deposit their burdens in far-distant places. During one whole half-day, when approaching Kalgan, the air was so full of dust that it was impossible to see the teams that were passing on the other side of the road. In crossing the mountains west of Shiwantse, as already remarked, this dust was found to have accumulated on the lee side in drifts which rivaled the mountains themselves in size.

One can therefore easily believe, with Baron Richthofen, that the loess of China is dust which has been blown in from the arid plains of Mongolia; and he 
may asso believe, with Dr. Holst, that it is a glacial grist originally brought down by the mountain streams which now disappear in the Desert of Gobi, but which formerly deposited their burdens upon the shores of the vast sea which at one time filled that inclosed basin. Upon the drying-up of this sea at the close of the Glacial epoch, the abundant material was at hand to be swept along by the winds, and account for the relatively rapid accumulation of loess which during that epoch evidently took place in the mountainous border of Eastern Mongolia and Northern China. At the present time the erosive agencies are remoring these deposits of loess in the mountains much more rapidly than they are accumulating, and are distributing it upon the lower levels of China. The vast plain penetrated by the great Chinese canal consists, as we have remarked, of loess brought down from this border and redistributed by the overflowing Hoangho.

The correctness of this theory concerning the glacial origin of the Chinese loess is strongly confirmed by the contrast presented by those regions which are similarly related to the Desert of Sahara. Here we have the same vast arid region, in corresponding latitudes, swept by prevailing westerly winds, but there is no accumulation of loess in Egypt or Arabia or in the mountains of Syria. There is plenty of sand, but evidently there 
was no loess for the wind to blow. These facts, it would seem, would effectually negative the theory of Richthofen, and some others, that the original formation of loess is to be attributed to the subaerrial disintegration of rocks in arid regions; for nothing can be more arid than the Desert of Sahara, and nowhere is loess so conspicuously absent as over those regions towards which the winds of the Sahara blow.

But, whatever doubts might be raised respecting such a recent depression of land as we have supposed in China, they cannot well exist concerning a corresponding depression on the other side of the great Central Asiatic plateau, facing Siberia and Turkestan. At the foot of the lofty Ala-tau Mountains, which border this plateau on the northwest, the Russian military road runs for five hundred miles along a terrace of loess, from two thousand to three thousand feet above oceanlevel, whose constitution is precisely like that of Northern China. To the south the mountains rise in successive peaks to a height of from fifteen thousand to twenty-three thousand feet; while to the north a rapidly descending plain stretches almost without a break more than two thousand miles to the Arctic Ocean. To one who travels this region with open eyes, there can scarcely be any question, that, at a comparatively 


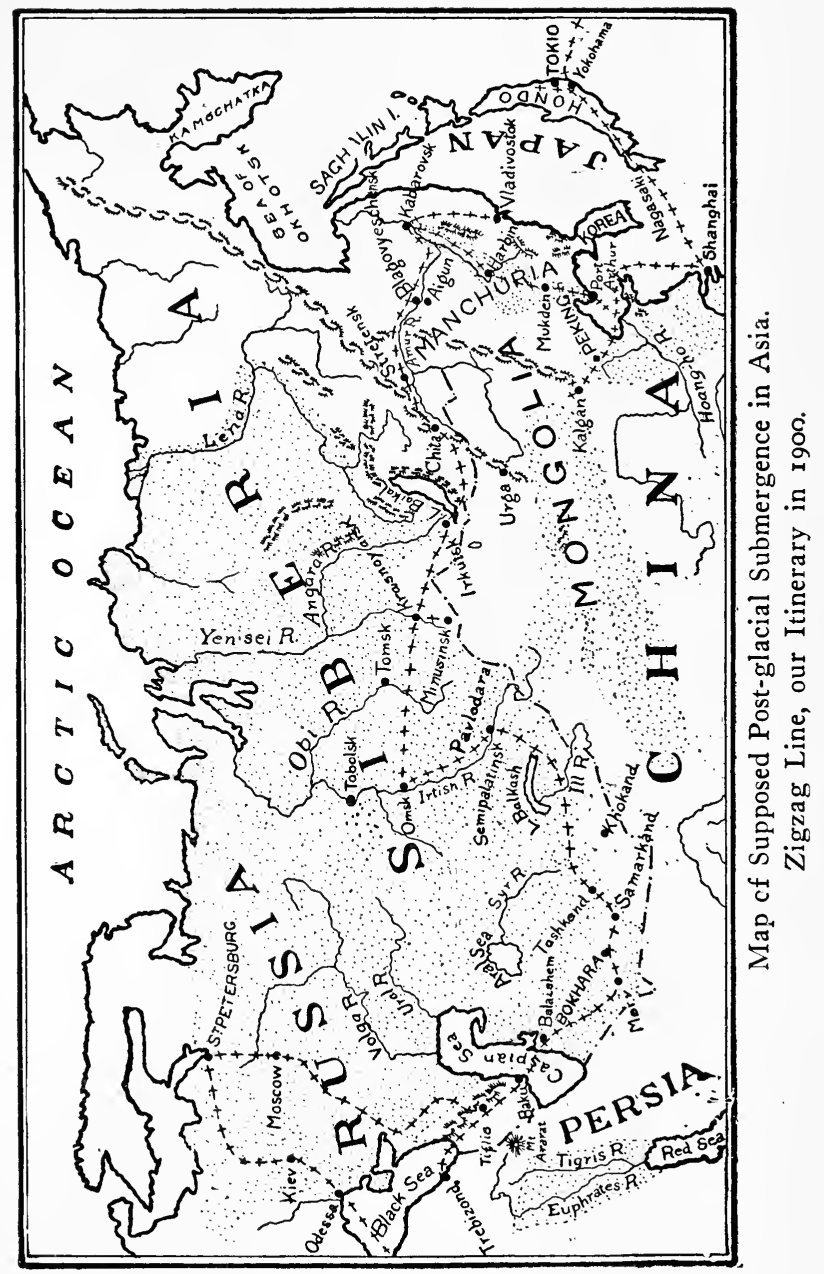


recent period, these waters washed the shores of the Asiatic plateau at an elevation of between two thousand and three thousand feet above present sea-level. On the shores of this great inland extension of the Arctic Sea are the sites of the present cities of Verni, Pishpek, Chimkent, Tashkent, and Samarkand,--cities which now occupy the very center of the Asiatic continent. Lake Balkash, the Aral and Caspian seas, with innumerable other small depressions, are in the desiccated bed of this late oceanic bottom.

Similar extensive deposits of loess occur in the valley of the Araxes, in Armenia, up to the base of Mount Ararat, and characterize other valleys in Northern Persia ${ }^{-}$and in Transcaucasia.

\section{CORROBORATIVE EVIDENCE.}

Among the most interesting corroborations of this theory is the occurrence of Arctic seal in the waters of Lake Baikal and of the Caspian Sea. It would seem impossible to account for this remarkable distribution of the species except on the theory that the whole intervening space had been recently covered with salt water, converting Lake Baikal into an oceanic bay. Upon the elevation of the land so as to sever the connection with the sea, this lake would so gradually change its character from salt to fresh water, that the species of seal left 
in it could become adapted to fresh-water conditions and thus remain as additional evidence of the recent geological changes of level. In the Caspian Sea, closely allied species of seal are also to be found. But nowhere else do they occur so far away from the ocean. The slightness of the changes which have taken place in the species indicates the very recent date of the geologic events which have brought about the wide dispersion and perfect isolation of this curious animal.

We have already referred to another class of facts pointing to the recentness of the great geologic changes in this region, namely, that, contrary to the general rule respecting lakes and seas without outlets, Lake Balkash and the Caspian and Aral seas are less salt than the ocean. The water of the Caspian Sea is only one-third as salt as the ocean, while that of the Arai Sea is so fresh that animals drink it, and that of Lake Balkash is fresher still. This points to a very recent period when the outlets ceased to carry a surplus of water into the ocean sufficient to freshen them. Time enough has not yet elapsed for them to accumulate salt equal to that in ocean water, much less to that in such inclosed basins as Great Salt Lake and the Dead Sea.

Further corroborative evidence is found in a study of the climatic changes of Central Asia-a subject which presents one of the most complicated and difficult 
problems with which science has to do. If it can be shown that our theory of a recent extensive subsidence of the continent, followed by a subsequent rapid reelevation, will solve this problem, that very fact will go far to establish its truth.

Briefly stated, the facts to be coördinated are as follows: The Aral and Caspian seas occupy central points of an inclosed basin, covering more than two million square miles, which has no present connection with the ocean. The surface of the Caspian Sea is eighty-five feet lower than that of the Mediterranean, while its depth is more than two thousand feet. So slight is the elevation of the land between the Azov and Caspian seas, that a depression there of less than thirty feet, or a rise in the Caspian of a little more than one hundred feet, would now permit their waters to mingle through the long marshy lake of Manytch. There are abundant evidences, in fossils and old shore-lines, that these seas were connected up to recent times, and that for a period there was an overflow of water from the whole AralCaspian depression into the Sea of Azov, and so on into the Mediterranean Sea and the Atlantic basin.

In order to secure this overflow, the precipitation over the basin must be greatly increased, or the evaporation diminished. But we are not limited to the Ural and the Volga and the rivers of the Caucasus for this 
formerly increased water supply. The Aral Sea, which now occupies an inclosed basin by itself within the greater inclosure, formerly overflowed its banks, and poured into the Caspian a volume of water greater than that of Niagara. The deserted channel of this old stream, known as the Uzboi, is easily traceable. Its length is about five hundred miles, and so distinct is the channel, that Russian engineers followed it a few years ago, in their survey for a canal to give water communication between the two seas. The only difficulty with the canal project was the lack of water to fill it.

The level of the Aral Sea is maintained by the two historic rivers, the Oxus and Jaxartes, now known as the Amu Daria and the Syr Daria. Both these rivers rise in the high mountains of Central Asia, and through the summer are abundantly supplied with water derived from the melting of the snows which cover the mountain summits. Each of these rivers has now about the same capacity as the Niagara. But so fierce is the evaporation over the region (where there is an annual rainfall of only three or four inches), that all this vast water supply is returned directly to the clouds.

Going farther east, we come to the river Chu, which descends in great volumes from the Tian Shan Mountains, and disappears in the desert before reaching the Aral Sea. Still farther east, the Ili and various other 
smaller rivers come down from the same mountain heights, and disappear in Lake Balkash; while numerous other shorter streams disappear in the desert long before forming a junction with the larger bodies of water. Indeed, the whole region is dotted with dried-up lake beds, where a saline deposit covers the whole surface.

Upon reaching the Irtysh River, we find it coming down through a depression between the Tian Shan and Altai Mountains about two thousand feet above the sea, leading over into the inclosed basin generally known as the Desert of Gobi, although that designation properly covers only the eastern part of the area. The western part is occupied by the basin of the Tarim River, ending in Lob Nor. This basin is surrounded by the Tian Shan Mountains on the north, and the mountains of Tibet on the south, many of their peaks reaching more than 20,000 feet above sea-level. We have but imperfect knowledge of the general elevation of the basin, but we know that Turfan, at about its center, is one hundred and fifty feet below sea-level; while the general level is certainly much below that of the Sungarian depression, which at that point forms the watershed between it and the plains of Northern Siberia.

Over this vast interior basin, also, as over that of the 
Aral-Caspian depression, there is abundant evidence of its former occupation by water. All through Tertiary times this sea, far greater in extent than the Mediterranean, was in existence, having a connection with the northern ocean through the Sungarian depression, as the Mediterranean has with the Atlantic through the Strait of Gibraltar. But by a gradual elevation of the land the sea became separated from the ocean, and through excessive evaporation the waters gradually disappeared, until now there remain only a few insignificant lakes, fluctuating in size with every changing season of the year. But that this body of water continued in considerable dimensions down to recent times is shown by the references to it by Chinese historians under the designation of Han Hai. There is likewise much evidence of the existence of flourishing cities in various places of the desert where now a water supply is out of the question, and where drifting sands cover ruins of considerable magnitude." Dr. Tschernyschev, Director of the Russian Geological Survey, informs me, upon the basis of recent personal investigation, that, at levels considerably above Kalgan, there are great deposits of loess around the borders of this old sea, which clearly show the marks of deposition in water.

We have already spoken of the former limited enlargement of the glaciers in the Tian Shan and other 
surrounding mountains in Central Asia. At first thought it might seem that the conditions causing this enlargement of the glaciers were the cause of the inland sea covering the Desert of Gobi, for the enlargement of the glaciers implies either an increased precipitation or a diminution in temperature involving a diminution of evaporation, or both. On the other hand, it may be plausibly urged that the enlargement of the glaciers is the effect of the inland sea, rather than the cause; for it is this very enlargement of the inland sea which would provide the increased evaporating surface needed to supply the increased precipitation upon the surrounding mountains.

Upon following out this theory in all its details, it is surprising how many mysteries it unlocks. Supposing a general subsidence in Central Asia such as to let in the waters of the sea all over the Aral-Caspian depression, and over the adjoining plains of Siberia up to the level of the Sungarian depression in the line of the Irtysh River, and of Lake Baikal in the line of the Angara, we should have the vast interior basin of the Gobi Desert filled with water connected with the ocean. The existence of such an expanse of water, as already remarked, readily accounts (I) for the anomalous dispersion of Arctic seal, so that they now remain denizens 
of isolated bodies of water as far separated from the ocean and from each other as are Lake Baikal and the Aral and Caspian seas; and there seems no other explanation of this anomaly.

(2) The presence of this vast expanse of water in Central Asia would likewise readily account, as we have just remarked, for the increase of the glaciers in the Altai and Tian Shan Mountains, since it is well known that increased moisture in the air is even more essential to the growth of glaciers than a lowering of the temperature. A heavy snowfall is one of the most important factors in the production of a glacial epoch.

(3) But it is in its relation to a diminishing rainfall of the Aral-Caspian basin that this theory furnishes the most important key to a complicated problem. In reflecting upon the evidence that the Aral Sea formerly overflowed into the Caspian, and the Caspian into the Sea of Azov, one cannot fail to ask how it came to be that the Amu Daria and the Syr Daria, the two great tributaries, should formerly have doubled their flow of water, and then gradually diminished to the present proportion. Our theory solves the riddle. Upon the reëlevation of the continent, so that the waters of the invading ocean could no longer penetrate to the inland sea through the Sungarian depression, the desiccation of that region began. For a long time the evaporation 
over the inland sea furnished the recessary moisture to keep up the enlarged flow of the rivers upon the north side of the Tian Shan Mountains. But, as about half of the water precipitated upon these mountans would flow off into the Aral-Caspian depression and the Arctic basin, and only one-half flow back into the inland sea, the water would gradually diminish, and in diminishing would deprive the rivers upon the other side of the mountains of their normal supply, until the present inadequate flow was reached.

In the same manner, also, we may account for the limited glacier that formerly came down from the summit of the Lebanon Mountains into the head of the Kadisha Valley, and built up the moraine upon which the surviving grove of the cedars of Lebanon is now giowing." In speaking of the former extension of the Dead Sea until it filled the whole Jordan Valley to a depth of seven hundred and fifty, and probably fourteen hundred, feet, reference was made to the Glacial epoch as the probably cause of this enlargement of these inland waters. But, as the only signs of glaciation in the Lebanon Mountains are around the summit level which drains into the Mediterranean, the two things can be only indirectly related. As in the case of the glaciers of the Tian Shan Mountains, may it not be quite as iikely that the glaciers of the Lebanon Mountains were 
caused by the increased evaporating surface of the body of water which filled the Jordan Valley as it emerged from the general depression to which we have referred the Deluge?

Tradition has long pointed to Central Asia as the original home of mankind, and evidence accumulates going to show that the conditions of life were once more favorable in that region than they are at the present time. Large tracts of land in Central Asia are now arid and barren which once supported a dense population, while many of the races of mankind certainly migrated from that region. The spread of the IndoEuropean or Aryan language is one of the most striking evidences that Central Asia was the original home of mankind. These languages include the classic and nearly all the modern languages of Europe and that of Persia, together with the Sanscrit, the sacred language of India. The evidence is irresistible that before the dispersion of the people speaking these languages they dwelt together as a pastoral people in the highlands on the southern border of the Aral-Caspian depression.

From this same center may be traced in successive waves of emigration the various Tartar races which have been consolidated into the great empires of Eastern 
Asia, and, penetrating into the more inhospitable regions of the north, reached Finland upon the one hand and Bering Strait upon the other, passing thence into America. One traveling in Central Asia even now will often be startled by the resemblance of the natives to the North American Indians.

Surging back from the eastern borders of Asia, these restless tribes of Tartars have repeatedly overwhelmed their original home, and rolled in a wave of conquest into Europe, where the Huns have left their permanent mark upon Western civilization. The followers of Jenghiz Khan, coming from Northeastern Mongolia, swept over all Central and Western Asia, and were only stayed in their destruction by fierce battles fought on the plains of Hungary and Poland. At the time of the conquest of Jenghiz Khan, Merv and Samarkand and Balkh were cities rivaling in population and magnificence all but a few of the commercial capitals of modern times.

MORE POSITIVE EVIDENCE.

But the most definite evidence of a recent considerable depression of this general area arrested our attention in I900 at Trebizond, on the south shore of the Black Sea. Here, at an elevation of six hundred and fifty feet above the sea, there is an extensive deposit of 


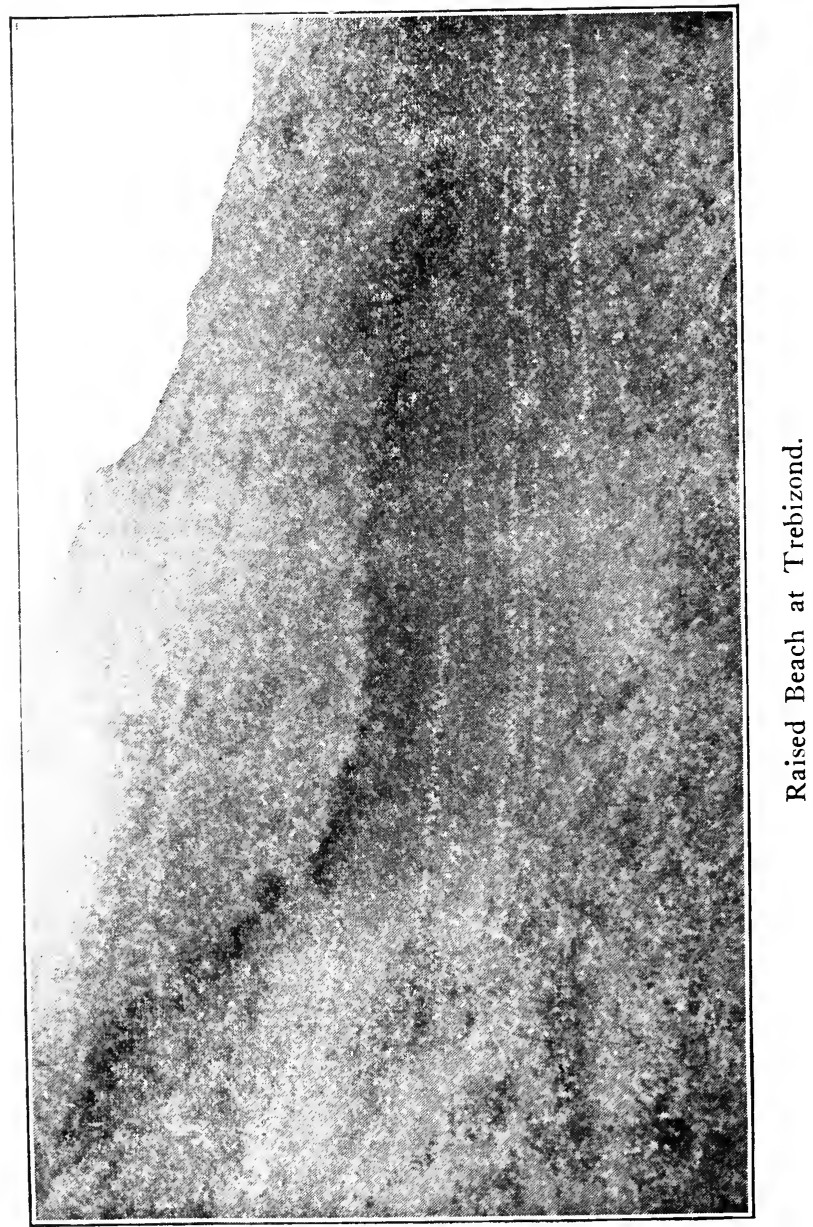


beach gravel clinging to the side of the volcanic mass of rocks at whose base the city is built. The appearance of the gravel is so fresh as to compel a belief in its recent origin, while it has certainly been deposited by a body of water standing at that elevation after the rock. erosion of the region had been almost entirely effected. The gravel deposit is about one hundred feet thick, and extends along the precipitous face of the mountain for a half mile or more. Some scattered gravel was found at a height of seven hundred and fifty feet. But the level summit of the mountain, at an elevation of eight hundred and fifty feet, was completely free from it. Professor Charles R. Keyes writes me that, in his excursion with the Russian geologists during the international convention of 1899 , he observed extensive raised beaches of corresponding height at Soudak, on the south shore of the Crimea, nearly opposite to Trebizond.

It needs but a glance at a map of the region, in any physical geography, to show that such a depression as would bring the south shore of the Black Sea down to seven hundred and fifty feet below its present level would produce an uninterrupted sea from there to the Arctic Ocean, thus covering with water all the plains of Southern Russia and Northern Siberia. Now, it is in just this submerged area of Southern Russia that we 
find another most extensive and important deposit of loess such as we have described in Northern China, and Turkestan. This is known and generally referred to as the "black earth" of Southern Russia, and constitutes its most fertile area. As to the origin of this, the Russian geologists inform us that, in their opinion, as in ours, whatever may be true of the loess deposits in China, not wind, but water, must have been the agency by which that of Russia was mainly distributed. ${ }^{7}$

\section{REMIAINS OF ANTEDILUVIAN MAN.}

This brings us to the point of supreme interest. At Kief, on the Dnieper, one of the largest tributaries of the Black Sea, Professor Armaschevsky has found human implements and burnt stones, in connection with the bones of extinct animals, at a depth of fifty-three feet below the undisturbed surface of the loess which covers the region. The facts he has fully described in a pamphlet prepared for the World's Geological Congress which met in Russia in I 899. The professor was so good as to conduct us over the field, and explain the entire situation to us. If there had been any doubts in our minds as to the significance of the facts before this explanation, there could be none after.

This was at an elevation of three hundred feet above the Inieper River, where an old camping place of 


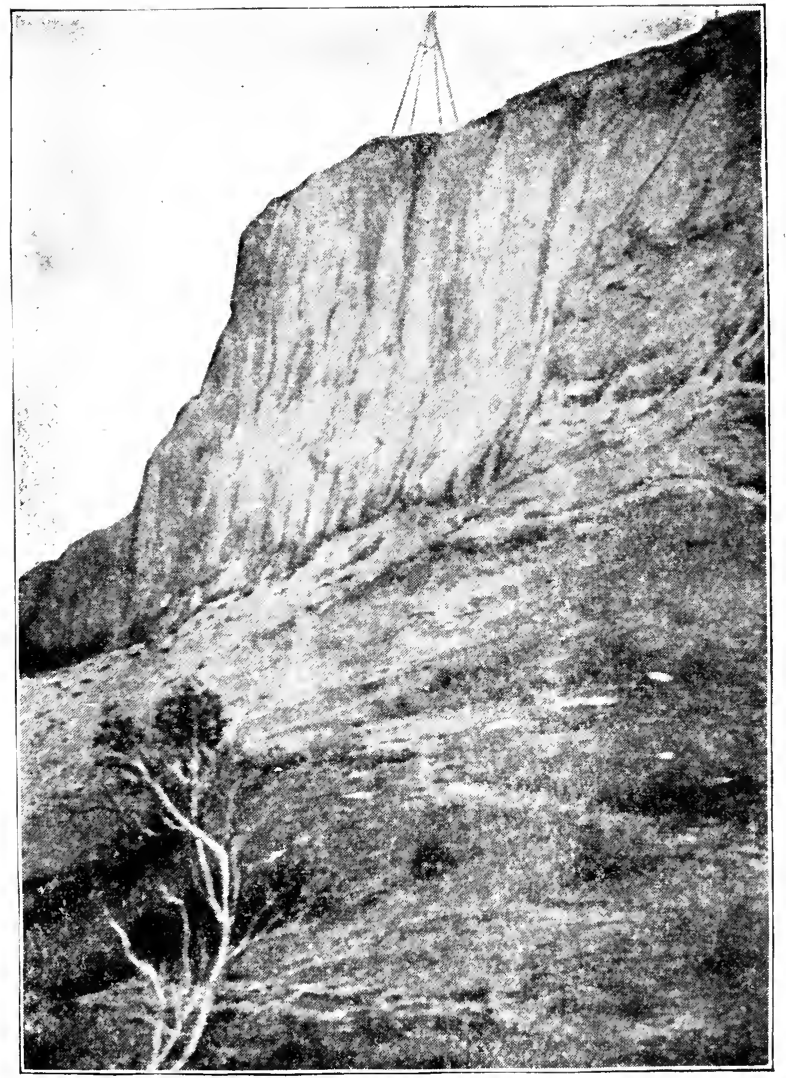

Bluff of Loess at Kief, Russia.

This bluff caps a glacial deposit, 250 feet above the Dnieper River. The human remains were found at the base of the loess, $5 \mathrm{I}$ feet below the surface. (Photograph by G. F. W'right.) 
palæolithic man rested on the surface of a glacial deposit containing granitic pebbles from Scandinavia, several hundred miles distant.

Other evidence of a recent submergence of Northern and Central Asia is reported by J. Stadling ${ }^{8}$ near the mouth of the Lena River, and ten miles back from it, where he found, six hundred feet above the sea, "in a layer of soil composed of turf and mud mixed with sand, resting on a foundation of solid ice as clean and blue as steel and of unknown depth, large quantities of driftwood, evidently brought down by the river at the remote period when it had its course here." Still another instance is one (which I have elsewhere described ${ }^{9}$ ) in the lower part of the Dariel pass, on the north side of the Caucasus Mountains, where there are extensive fluviatile deposits of such character as to indicate a great change in the relative level of the gorge in correspondingly recent times. In the same line of evidence is the report of Professor John J. Stevenson upon recent changes of level in Spitzbergen. The facts are, that towards the close of the Tertiary period there was clearly a rapid elevation of the land, amounting possibly to four thousand feet, which was followed by a subsidence of still greater extent; while now the land is slowly regaining its original level. Raised terraces and 
sandy beaches of recent origin bear witness to this in many places. ${ }^{10}$

All these things point to the fact that in those worldwide movements which characterized the latter part of the Tertiary and the whole of the Glacial period, there was a brief subsidence of the Asiatic continent-Central Asia, perhaps, playing see-saw with Northwestern Europe and Northeastern America, the one going down while the other went up. But, however that might be, at some stage during this late period of geological instability, a general depression of Central Asia must have occurred to account for the phenomena we have presented, distributing the loess in the peculiar manner indicated and filling the central depression of Mongolia with an interior sea.

It is beyond legitimate question, therefore, that, since man was a resident in Southern Russia, there has occurred the great subsidence which occasioned the widespread and rapid accumulation of loess over that vast area which we have been describing, thus bringing the facts in Southern Russia and Central Asia into chronological harmony with those in Western Europe and North America, where the remains of glacial man have been known to exist. Early man certainly witnessed in the eastern continent changes of land-level causing floods on a scale such as the race has not been familiar 
with for several thousand years. Man undoubtedly came into the world before the unstable equilibrium accompanying late Tertiary time and the whole course of the Glacial epoct had given jlace to the comparative quiet which now prevails. 


\section{CHAPTER X.}

\section{THE DELUGE IN NORTH AMERICA.}

FOr a long time the public has been familiar with the fact that the Glacial epoch in North America was succeeded by an extensive depression of land in the northern part, permitting water to overflow a large area in the eastern portion of the continent lying north of the Canada line. From the prominence of the facts in the Champlain Valley, Professor James D. Dana early gave to the period of this depression the name of the Champlain epoch. Abundant sea-shells are found, at various elevations in the Champlain Valley, superimposed upon the ordinary glacial deposits. The skeleton of a whale was found, many years ago, in the Champlain clays of Vermont, at an elevation of three hundred or four hundred feet above the sea; while shore-lines of this arm of the ocean are clearly traceable upon both the Adirondack and the Green Mountains, which form borders upon the opposite sides of the valley. Near the Canada line, and at Montreal, these post-glacial seabeaches, with their accompanying sea-shells, occur to a height of six hundred feet; while, at Arnprior, far up 
the Ottawa River, at an equal elevation, the skeleton of a whale has been found in post-glacial clay deposits. Evidently, therefore, at the melting-off of the glacier from Eastern North America, the Gulf of St. Lawrence extended so as to make a continuous sheet of water from the ocean to the Great Lakes. Going farther north. this depression of land increased in extent, amounting to one thousand feet or more in the region northeast of Hudson Bay. So far the facts correspond somewhat closely with those we have presented pertaining to the post-glacial depressions of land-levels in Europe and Asia.

But there is another class of facts, of extreme interest, dependent upon the physical geography of the country, which, if they do not have a direct bearing upon our subject, do have a very important indirect bearing upon it. We refer to the remarkable series of temporary lakes which were formed along the southern edge of the ice as its front slowly receded from its extreme southerly extension. ${ }^{1}$ At the climax of the Glacial epoch in North America, the continental glacier extended to an irregular line drawn along the southern coast of New England, passing just south of New York City, and in irregular course through New Jersey, Pennsylvania, and Ohio, until, at Cincinnati, it crossed the Ohio River into Kentucky, and thence 
passed westward with various irregularities until it reached its most southern point, at Carbondale, Ill., in about latitude $38^{\circ}$. Thence, passing northwesterly, it crossed the Mississippi River for a little at St. Louis, but followed closely the northern shore of the river for more than half the distance across the State of Missouri. Crossing it, however, for a little distance below the sharp angle made by the river at Kansas City, it follows the Kansas River as far west as Topeka, whence it turns northward, and, bearing a little to the west, reaches the Canadian line in Montana, and there joins the boundary of the Cordilleran lobe of ice, which came down the border of the Pacific Ocean. A glance at the accompanying map, in which the various stages of the glacier are shown by dotted lines, will reveal the facts better than any amount of verbal description. It will be in place, however, briefly to outline the several glacial lakes which attended this recession, and which have been variously named as the facts have come to light.

I. Lake Ohio.--This was formed by the damming of the Ohio River at Cincinnati, when the front of the glacier crossed over into Kentucky. During a short time this obstruction to the channel existed through a length of nearly one hundred miles. Such an obstruction would pond up the water in the valley above to a depth of five hundred feet, flooding an area of nearly 


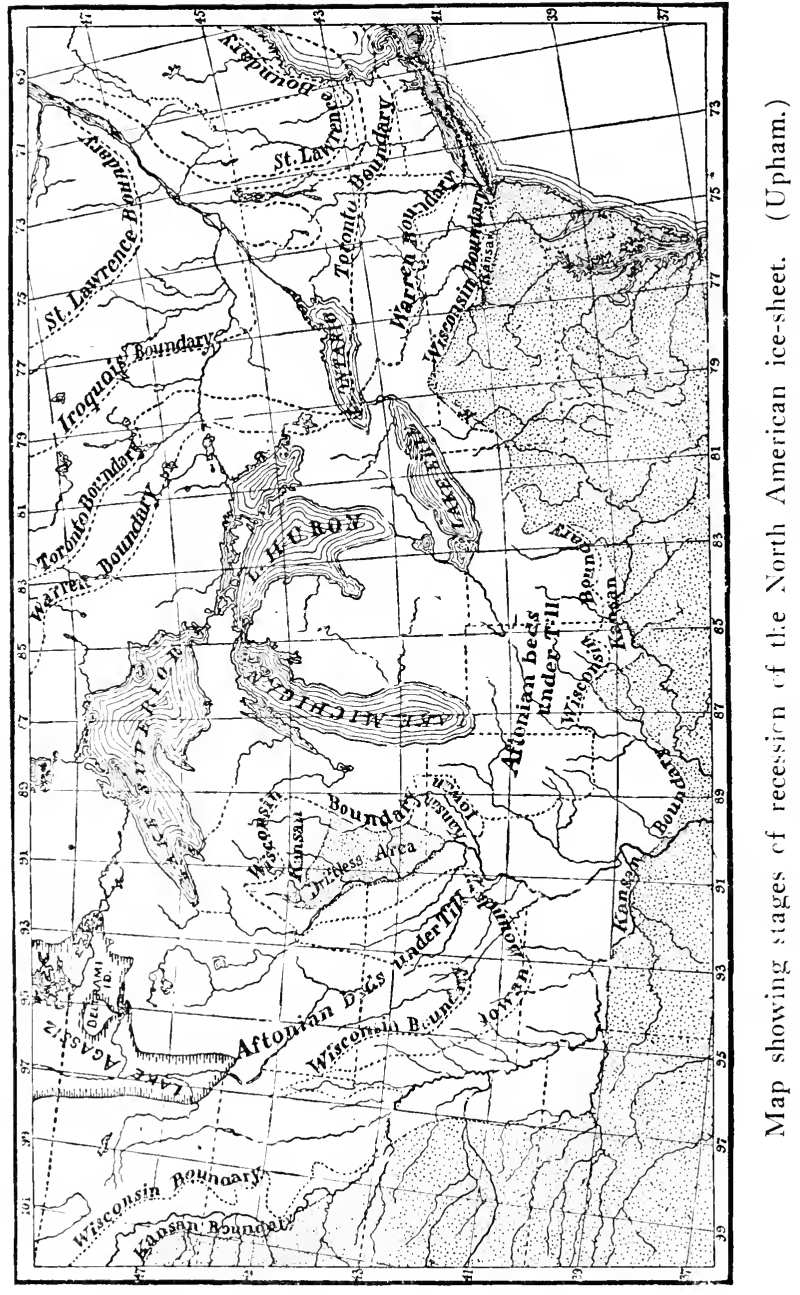


twenty thousand square miles, and producing a depth of water over Pittsburgh of nearly three hundred feet. Professor E. W. Claypole, in an article read before the Geological Society of Edinburgh and published in their "Transactions." has given a very vivid description of the vicissitudes of this remarkable body of water:-

"The Ohio of to-day in flood is a terrible danger to the valley, but the Ohio then must have been a much more formidable river to the dwellers on its banks. The muddy waters rolled along, fed by innumerable rills of glacier-milk, and often charged with ice and stones. The first warm days of spring were the harbinger of the coming flood, which grew swifter and deeper as summer came, and only subsided as the falling temperature of autumn again locked up with frost the glacier fountains. ... The ancient Ohio River system was in its higher part a multitude of glacial torrents rushing off the icesheet, carrying all before them, waxing strong beneath the rising sun, till in the afternoon the roar of the waters and their stony burden reached its maximum, and, as the sun slowly sank, again diminished, and gradually died away during the night, reaching its minimum at sunrise. . .

"But, with the steady amelioration of the climate. more violent and sudden floods ensued. The increasing heat of summer compelled the retreat of the ice from the Kentucky shore, where Covington and Newport now lie, and so lowered its surface that it fell below the previous outflow-point. The waters then took their 
course over the dam, instead of passing, as formerly, up the Licking and down the Kentucky River Valley. The spectacle of a great ice-cascade, or of long icerapids, was then exhibited at Cincinnati. This cataract, or these rapids, must have been several hundred feet high. Down these cliffs or this slope the water dashed, melting its own channel, and breaking up the foundations of its own dam. With the depression of the dam the level of the lake also fell. Possibly the change was gradual, and the dam and the lake went gently down together. Possibly, but not probably, this was the case. Far more likely is it that the melting was rapid, and that it sapped the strength of the dam faster than it lowered the water. This will be more probable if we consider the immense area to be drained. The catastrophe was then inevitable-the dam broke, and all the accumulated water of Lake Ohio was poured through the gap. Days or even weeks must have passed before it was all gone; but at last its bed was dry. The upper Ohio Valley was free from water, and Lake Ohio had passed away. . .

"But the whole tale is not yet told. Not once only did these tremendous floods occur. In the ensuing winter the dam was repaired by the advancing ice, relieved from the melting effects of the sun and of the floods. Year after year was this conflict repeated. How often we cannot tell. But there came at last a summer when the Cincinnati dam was broken for the last time; when the winter with its snow and ice failed to renew it, when the channel remained permanently clear, and 
Lake Ohio had disappeared forever from the geography of North America. . . .

"How many years or ages this conflict between the lake and the dam continued it is quite impossible to say, but the quantity of wreckage found in the valley of the lower Ohio, and even in that of the Mississippi, below their point of junction, is sufficient to convince us that it was no short time. "The age of Great Floods' formed a striking episode in the story of the 'Retreat of the Ice.' Long afterward must the valley have borne the marks of these disastrous torrents, far surpassing in intensity anything now known on the earth. The great flood of 1885 , when the ice-laden water slowly rose seventy-three feet above low-water mark, will long be remembered by Cincinnati and her inhabitants. But that flood, terrible as it was, sinks into insignificance beside the furious torrent caused by the sudden, even though partial, breach of an ice-dam hundreds of feet in height, and the discharge of a body of water held behind it, and forming a lake of twenty thousand square miles in extent.

"To the human dwellers in the Ohio Valley-for we have reason to believe that the valley was in that day tenanted by man-these floods must have proved disastrous in the extreme. It is scarcely likely that they were often forecast. The whole population of the bottom lands must have been repeatedly swept away; and it is far from being unlikely that in these and other similar catastrophes in different parts of the world, which characterized certain stages in the glacial era, 
will be found the far-off basis on which rest those traditions of a flood that are found among almost all savage nations, especially in the north temperate zone."

2. Lake Warren.-This is named from its discoverer, General Warren, of the United States Army. When the ice-front had retreated beyond the watershed between the basins of the Mississippi and the St. Lawrence, there began to be an accumulation of water along its margin, which gradually enlarged until it covered the whole area now occupied by the valleys of Lake Erie, Lake Ontario, and Lake Huron, the outlet being, first, at Fort Wayne, into the Wabash River, at an elevation of two hundred feet above Lake Erie (775 above the sea), and later, as the ice melted off from the lower peninsula of Michigan, through a passage leading from Saginaw Bay through Grand River into a body of water that was formed in a similar manner, covering the southern part of Lake Michigan. This outlet was one hundred feet lower than the one at Fort Wayne. Thence the mighty torrent poured along the line of the present drainage canal, a few feet above the level of Chicago, into the Illinois River, and onward into the Mississippi. 'The receding shore-lines of this - vast body of water are clearly traceable all around the southern shores of Lake Erie, and up to Saginaw Bay, in Lake Michigan; while the cisserted channels 
at Fort Wayne, and through the Grand River Valley, and along the line of the Chicago Drainage Canal are as clearly marked as those of any existing river.

3. Lake Algonquin.-This is the name given to the body of water in front of the retreating ice whose level was determined by that of the pass from the Lake Ontario basin into the Mohawk River at Rome, N. Y. For a long while the mighty current swept through the Mohawk Valley into the Hudson, leaving its traces in extensive gravel terraces clearly discernible from fifty to one hundred feet above the present river. As the retreat of the ice proceeded, this body found an outlet, at a lower level, around the eastern base of the Adirondack Mountains, through the Champlain Valley. At Chazy, N. Y., immense windrows of water-worn pebbles and boulders can be traced where this stream passed through a depression between the melting lobe of ice on one side and the mountain on the other. Eventually this lake merged into the gulf which, as already said, extended up the St. Lawrence Valley at the time of the Champlain depression, when whales sported in those inland waters.

4. Lake Agassiz.-Passing over innumerable minor details, we will limit ourselves to a brief statement of the facts concerning the vast accumulation of water which formed in front of the retreating glacier in the 
valley of the Red River of the North, to which, very appropriately, has been given the name of Lake Agassiz. Here, so long as the ice remained to obstruct the drainage that naturally flowed into Hudson Bay, the water rose to the level of the pass from the Red River Valley into the Minnesota through Grand Traverse and Big Stone lakes. These lakes, each fifteen or twenty miles long and about a mile in width, are upon the same level with each other, and occupy minor depressions in what was the outlet of the immense glacial lake. At its culmination, before the ice-barrier to the north eventually broke away, Lake Agassiz covered an area of one hundred thousand square miles, including what are now the most fertile portions of Minnesota, Dakota, and Manitoba. It has left a precious legacy to mankind in the vast alluvial deposits over its bottom, which now furnish the most important wheatfields in the world.

5. Lake Bonnerille.-This was in Utah, and is named for Captain Bonneville, the intrepid original explorer of the region. Its modern representative, Great Salt Lake, has an area of only about two thousand square miles, with a depth of about twenty or thirty feet. But during the Slacial epoch, when the precipitation was greater and the evaporation less than now: the waters increased to a depth of one thousand feet, 
and covered an area of twenty thousand square miles. When the water had attained this depth, it began to overflow through the Port Neuf River into the Snake River Valley, leading into the Columbia River and the Pacific Ocean. But at the point of overflow there was an accumulation of unconsolidated earthy débris to a depth of three hundred and seventy-five feet. This obstruction rapidly wore away, and the whole body of water down to that level rushed in an impetuous torrent into the valley of Snake River.

Dr. G. K. Gilbert has given a vivid description of this in his monograph upon Lake Bonneville published by the United States Geological Survey; while I have, in "Man and the Glacial Period," detailed some of the more specific results of the gigantic flood as it poured down into the Snake River Valley. Dr. Gilbert estimates that it would require twenty-five years for a stream as large as Niagara to lower the level of Lake Bonneville three hundred and seventy-five feet. When one sees the diminutive rivulet now known as the Port Neuf, the imagination is utterly balked in its efforts to picture a Niagara flowing through it. But that such was the case is proved beyond controversy by the dry light of science.

The subsequent history of Lake Bonneville bears evidence, that, owing to the desiccation which followed 
the Glacial epoch both in the eastern and western continents, and to which we have already made frequent reference, gradually all the remaining body of water, to a depth of more than six hundred feet, has evaporated from the basin. Its deserted shore-lines, like railroad embankments, surround the valley and the mountains projecting from the basin, and form conspicuous objects in the landscape.

6. Lake Lahontan.-To the west of the Lake Bonneville basin a body of water of about equal size accumulated during the Glacial epoch, but never rose high enough to overflow. This is named Lake Lahontan, after another early explorer of this region, and has been fully described, in a monograph of the United States Geological Survey, by the late Professor Israel C. Russell. But it is not important here to go into details.

One of the most interesting of all the recently discovered evidences of the vast extent of glacial floods is that which was brought to light in 1903 respecting those of the Missouri River Valley. The facts are so striking and pertinent, as well as new, that it will be profitable to detail them at some length. In tracing the boundary of the glaciated region of the United States twenty years or more ago, it was discovered that west 
of the Mississippi River the continental glacier did not cross the Missouri River below Jefferson City. The testimony of the various geologists who had surveyed the region was very uniform upon this point. But in 1902 Dr. Ball, who was employed by the State to make a geological survey of Miller County, reported that

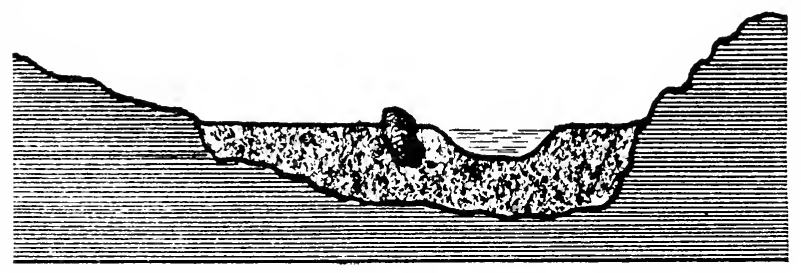

Cross-section of the Osage Trough at Tuscumbia, with a Canadian Boulder.

several large Canadian boulders were to be found at Tuscumbia, in the trough of the Osage River, about sixty miles above its junction with the Missouri, and fully forty miles south of the extreme limit reached by the continental glacier. Here was presented a problem of the greatest perplexity and interest, so that it was worth while for me to devote the summer of I 903 to its solution.

To account for these boulders, there were four, and only four, suppositions possible.

1. That there were outcrops of similar granite in 
the vicinity, so that the river floods could have brought the boulders into the places where they were found. But this was negatived by the unanimous testimony of the geologists who had carefully surveyed the region, that there are no outcrops of such granite in the State. Ioreover, Dr. Robert Bell, Director of the Canadian Survey, at once recognized the specimens as from Canada, which is several hundred miles away.

2. It might be supposed that there had been an error in previous observations on the limit of the glaciated area. The border south of the Missouri River was therefore resurveyed, with results conforming to those that had been previously obtained. There were no signs of an invasion of the continental glacier south of the river below Jefferson City.

3. It might be supposed that glacial ice had crossed the watershed between the Kansas River and the headwaters of the Osage River below Topeka, Kansas, where it was known to have reached the vicinity during its greatest extension. Under this theory, floating ice might have carried the boulders down to the lower part of the Osage River andd, becoming stranded there, left them where they were found. But this theory was negatived by a resurvey of this region, which confirmed all previous observations that the Kansas River marked the southern limit of the glaciated region in Kansas. 
4. The only supposition remaining was, that, during high glacial floods in the Missouri River when there were no corresponding ones in the Osage, back-water had carried small boulder-bearing icebergs from the Missouri sixty miles up the Osage, where they had been stranded, and, on melting, left the boulders as indubltable witnesses of a most startling geological episode. From the height at which the boulders at Tuscumbia were lying, it was necessary to suppose that the Missouri River was at that time subject to floods which rose two hundred feet, while the Osage had none to correspond. If such a condition of things could be reasonably, or even possibly, supposed, it would be sufficient to account for the phenomena; while, in the absence of any competing theory, this must be acceptrd as proved beyond a reasonable doubt.

It is a well-known fact that a rise in the main stream without a corresponding rise in the tributary causes a current to set back up the tributary, and so carry débris up stream. A case near my ancestral home had early attracted my attention. Poultney River, in Vermont. which comes into the head of Lake Champlain, was ar one time visited by a series of terrific thunder-showers, while one of its tributaries, Hubbardston Creek, was out of their reach. As a consequence, the main stream rose thirty or forty feet, and set up the creek with such 
force that it carried a mill-dam up stream. Instances of this sort could be multiplied indefinitely.

From the melting of snow in the Rocky Mountains, the Columbia River, in Oregon, often rises thirty or forty feet when its southern tributary, the Willamette, has reached its period of low water. At such times a current sets up the tributary, carrying driftwood past Portland, fifty or sixty miles from the Columbia. Similar phenomena are regularly witnessed in some of the tributaries of the Danube.

In the present case, there was, at the close of the Glacial epoch, a unique condition of things in the lower Missouri Valley. A glance at a glacial map of the region will show that about 250 ,000 square miles of the glaciated region would drain its surplus water into the trough of the middle Missouri. On a moderate calculation, the melting of the ice over this area towards the close of the period may have proceeded at the rate of ten feet per annum. This would furnish five hundred cubic miles of water for the lower Mis. souri River to handle each year between April and November; whereas now its total annual flow, as determined by the United States engineers, is only twenty-eight cubic miles; and yet, with that small amount, floods often rise to a height of thirty-six feet above low water. That there was, for a period of con- 
siderable length, a supply of five hundred cubic miles of water to the Missouri to be carried off during the summer and autumn months is a most reasonable supposition, supported by a large number of well-known facts. It is equally clear that, at this time, there were no causes to supply a corresponding rise of the Osage, since it lies wholly outside the glaciated region, and had no ice over its basin to be melted, and thus augment its volume.

On proceeding to work out the problem of the behavior of this vast body of water poured into the middle Missouri, it was first observed that it all had to pass through a narrow place in the trough at Hermon, twenty-five miles below the mouth of the Osage. Here the width of the trough between the rocky precipices, three hundred feet high on either side, is barely two miles. Mathematical calculations will show that it would require ninety-six days for a current two miles wide and two hundred feet deep, flowing three miles an hour, to carry off five hundred cubic miles of water. But as the supply of water would be in gradually increasing amount up to a little past mid-summer, and then as gradually decreasing, the average depth would be only half that, with a short period of extreme height. It would therefore require one hundred and ninety-two 


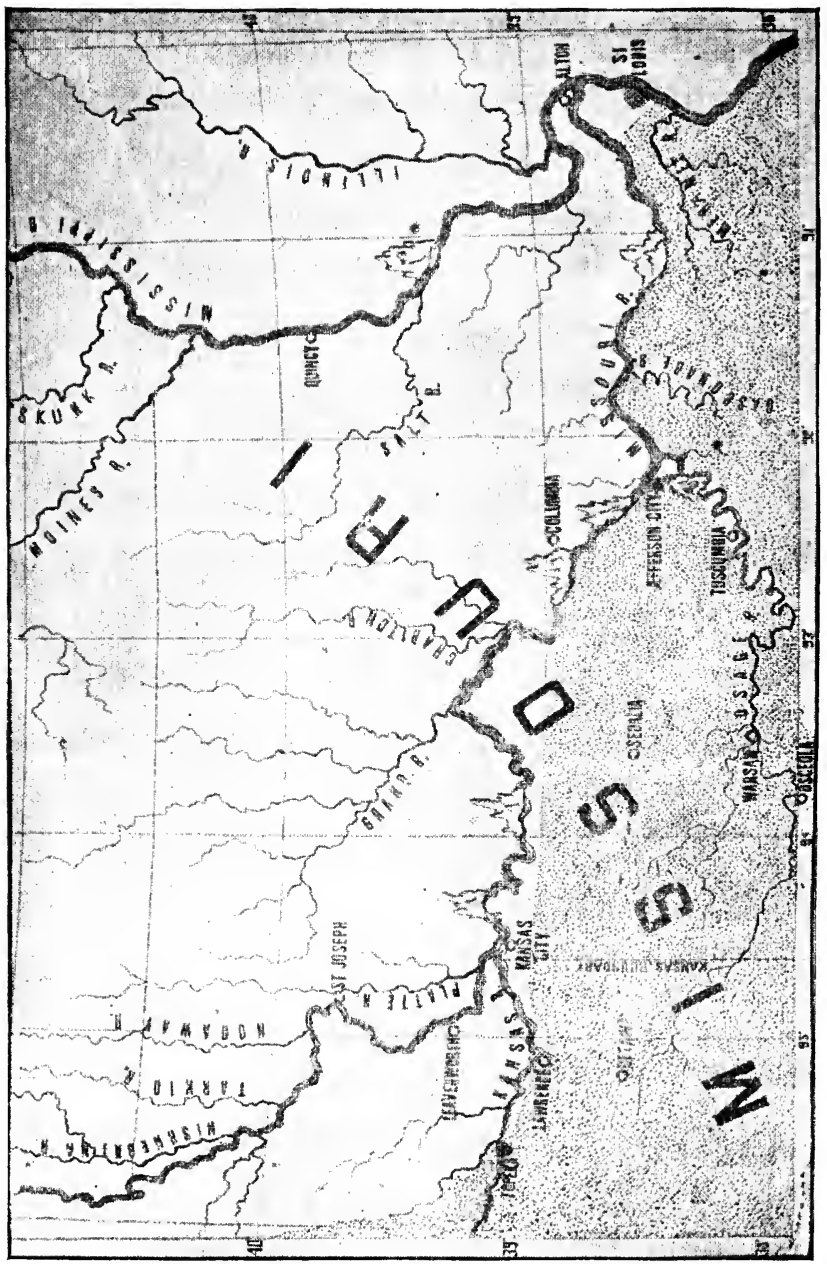


days to reduce the level to normal conditions, leaving scarcely any flow during the winter months.

In order to secure this moderate rate of three miles an hour, we must suppose, however, that the gradient of the stream was then considerably less than that of the Missouri at the present time. But this supposition is most reasonable, in view of well-known facts. For, as already shown, there is abundant evidence that, toward the close of the Glacial epoch, there was a depression of land over nearly all the glaciated area, and that this depression increased toward the north. At Montreal we know the land was six hundred feet iower at the close of the Glacial epoch than it is now. There is corresponding evidence of such a northerly depression around the Great Lakes and in Manitoba and Northern Minnesota. That this included, in diminishing degree, the whole glaciated area down to the middle of the State of Missouri, is in accordance with the whole analogy of the downward movement of the crust of the earth which accompanied, and perhaps was caused by, the accumulation of ice over it. Moreover, this supposed diminution of the gradient of the lower Missouri would be aided by the corresponding floods in the upper Mississippi and in the Ohio, which would, at the same time and from the same causes, raise the level of the 
outlet of the Missouri. We are therefore perfectly warranted in assuming this necessary lower gradient.

Under this supposition, the course of events can be easily outlined. Beginning with May of each year, the water from the melting ice over 250,000 square miles of territory would pour into the middle Missouri in increasing quantities until the middle of August, when it would attain a depth of two hundred feet, and spread out over all the adjacent country in a vast lakelike expanse. Into the central current, frequent icefloes, or small icebergs, with Canadian boulders in their frozen grasp, would find their way, and float downwards to the mouth of the Osage River. There, finding no counter-current, they could easily be carried up the trough as far as Tuscumbia, and stranded on the banks one hundred feet above the ordinary level of the Missouri. Thus was the problem solved without a flaw in the argument, or the use of a supposition which is at all unreasonable or out of analogy with the facts.

But this is not all. The supposition of such a re. curring temporary lake over the middle Missouri Valley is necessary to account for the peculiar distribution of the loess along the borders of its trough from $\mathrm{Da}$ kota to Kansas City. This deposit occurs to a remarkable extent all along either margin of the trough of the Missouri River, being more than one hundred 
feet thick at Sioux City, Council Bluffs, Omaha, St. Joseph, and Kansas City, Mo. Indeed, at St. Joseph, it is more than two hundred feet thick. Back from the margin the loess covers the area up to the level of about two hundred feet, but gradually thins out, and merges into ordinary clay or loam. As already said, however, the loess is not a clay, but an extremely fine sand, with a small amount of clay and lime intermingled. It contains few, if any, lacustrine shells, but many species of snail-shells, such as are now found in the vicinity, and flourish on the flood-plains of the streams. The character of these shells, and the difficulty of imagining a body of water from which the sediment could be derived, and of finding an adequate source for the water required, have led many to suppose that the loess was brought into its present peculiar position by the wind. It is suggested that during the floods of the Glacial epoch (which were supposed to be much more moderate than present facts prove them to have been), silt from the glaciated area was deposited over the flood-plain of the river, and from there blown up by the wind to the positions now occupied by it.

But in the Missouri Valley the primary agency of wind in the distribution of the loess is negatived by the fact that, while the prevailing winds are from the southwest, the loess is found on both sides of the river 
$3+4 \quad$ The Deluge in North America.

in about equal amounts, and also by the fact that it frequently occurs in level-topped terraces, such as could be formed only under water action. Finally, the positive evidence of recurring floods two hundred feet or more high in the Missouri, adduced from the occurrence of the Canadian boulders at Tuscumbia, comes in with convincing weight to furnish the zera causa, which had before been lacking. The temporary body of water which we suppose to have spread over the area covered by the loess necessarily contained a moving stream along the present course of the river. This would bring in the supply of sediment from the glaciated region needed to account for the special prominence of the deposit along the margin of the trough. It had been a valid objection to the theory of a standing body of water over the area, that the sediment would all be deposited around the northern margin; whereas it occurs in greatest excess for several hundred miles along the middle of the lacustrine area. This could be the case only if there was such a movement of water through it as our theory supposes." Furthermore, the temporary and recurring nature of the flood would account for the absence of lacustrine shells and the presence of land-shells, for they flourish in special degree on flood-plains which are only occasionally submerged for a short time. 


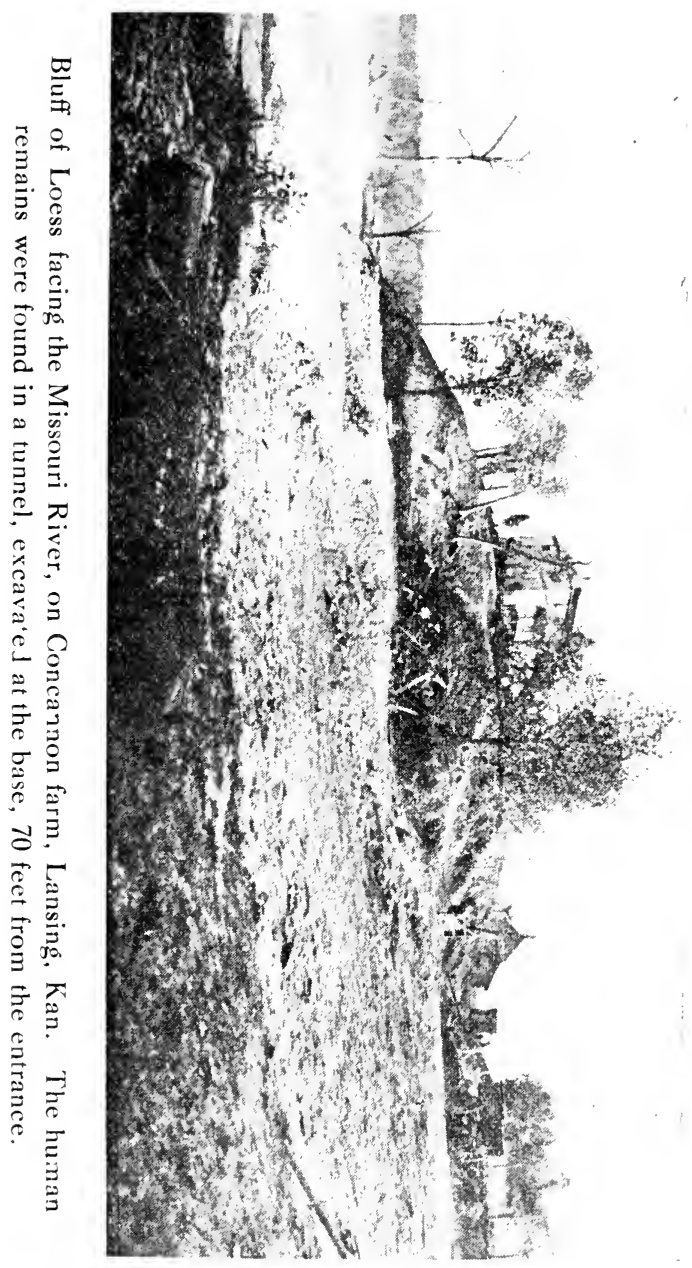


While these conclusions are of great importance in illustrating the general fact of the increased activity of certain natural forces during the Glacial epoch, they assume special importance, in the present discussion, from the fact that at Lansing, Kansas, near Leaven-

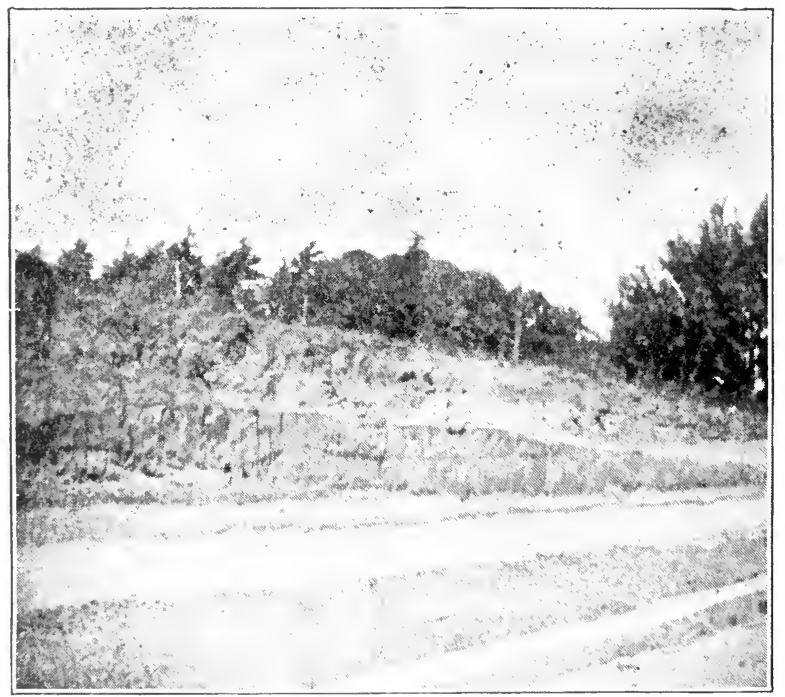

Stratified Loess at St. Joseph, Mo., $200 \mathrm{ft}$. Above the River. (Photograph by Miss Luella A. Owen.)

worth, a human skeleton was found buried at the base of an undisturbed section of this loess, showing that man was in the valley of the Missouri River before these floods attained their climax, and was, very likely, 
exterminated by them. Thus is added another instance to the many which can be adduced to show the destructive power of the floods which accompanied the close of the Glacial epoch during the period of man's existence both in the Old World and in the New. ${ }^{3}$

In view of these facts, it will appear that it is not an altogether improbable theory that, at the time of the Deluge, man had been largely exterminated by natural forces; so that he was then limited to a comparatively small area in Central Asia. In such extermination, he would only have shared the fate of a large number of animals that failed to survive the world-wide physical changes which accompanied the Glacial epoch. For it is well known that on both continents, at the close of the Tertiary period, there occurred a remarkable extinction of animals which is doubtless connected with the advance of the continental ice-sheet. Among these we may mention two species of the cat family as large as lions; four species of the dog family, some of them larger than wolves; two species of bears; a walrus, found in Virginia; three species of dolphins, found in the Eastern States; two species of the sea-cow, found in Florida and South Carolina; six species of the horse; the existing South American tapir, a species of the South American llama; 
$3+8$ The Deluge in North America.

a camel; two species of bison; three species of sheep; two species of elephants and two of mastodons; a species of megatherium, three of megalonyx, and one of mylodon-huge terrestial sloths as large as the rhinoceros, or even as large as elephants, which ranged over the Southern States to Pennsylvania, and the mylodon as far as the Great Lakes and Oregon.

In the Old World the assemblage of animals which were contemporary with glacial man, but became extinct in the temperate zone, is equally remarkable. It includes gigantic species of lion, tiger, leopard, hyena, bear, elk, musk-sheep, and reindeer, while the hippopotamus ranged as far north as Yorkshire, England, and, as we have seen, fed in vast herds on the plains of Sicily. But most striking of all is the case of the elephant. One species only four or five feet in height abounded in Malta and Sicily, and one in Malta that was less than three feet in height; a large species wandered as far north as Yorkshire. England; while the largest of all, the mammoth, spread over all Western and Central Europe, and fairly swarmed over the plains of Siberia and the adjacent islands. A brisk trade in ivory from their tusks is still kept up between Siberia and China. So recently has the mammoth become extinct in Siberia, that individuals are occasionally found, frozen in the ice, with their flesh still undecayed. 


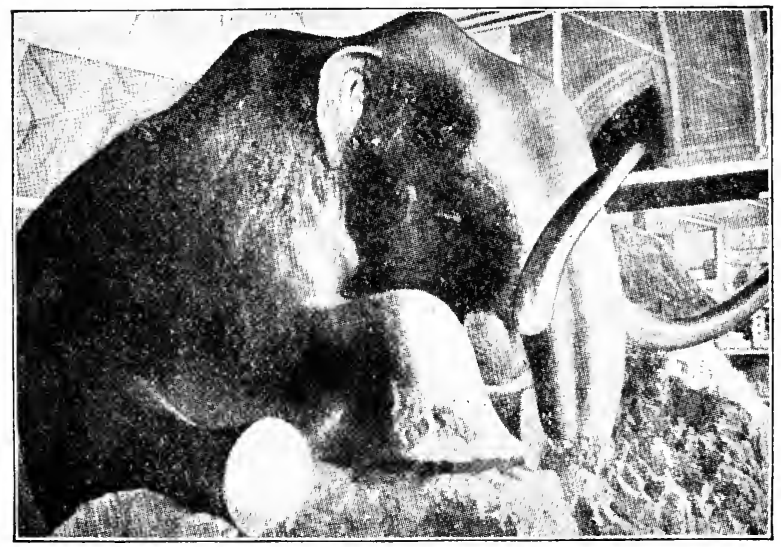

Mammoth from Siberia mounted in the Museum at St. Petersburg.

This mammoth was found in the year rgoo. Its skin and skeleton were transported to St. Petersburg by Mr. I. P. Tolmatschow. The carcass was at the bottom of a steep slope which rises to a height of $\mathbf{r} 70$ feet above the flood-plain of the Beresowka River. At this height a terrace stretches back for half a mile, where the land rises 300 or too feet higher to the general level of a forest-covered plain. The mammoth was completely enveloped in the frozen soil until washed out by the river. The appearance was as if, in stretching out to reach twigs, he had slid down backward in the position shown in the illustration, and there perished, to be frozen into the accumulating ice, and preserved for an unknown period of time. 
The accompanying illustrations speak louder than words. The specimen now mounted in the St. Petersburg Museum was found at the base of an ice cliff, covered with soil, on the Beresowka, which enters the Arctic Ocean east of the Lena. The climatic changes which first permitted this animal to flourish over this northern region and then led to his extermination are the most puzzling among the unsolved unscientific mysteries.

This wondrous assemblage of animals became extinct in connection with the Glacial epoch, as their remains are all found in post-Pliocene deposits. The intermingling of forms is remarkable. The horses, camels, and elephants which lived in North America before the Glacial epoch were found subsequent to it only in the Old World, while the llamas, tapirs, and gigantic Edendata are South American types. The progress of events seems to have been about as follows: In the warm period preceding the Glacial epoch, when the vegetation of the temperate zone flourished about the north pole, there was land connection across Bering Strait, permitting the larger species of the Old World to migrate to North America. At the same time the conditions in North America were favorable to the tropical species of animals which had developed 
and flourished in South America. The refrigeration of the climate on the approach of the Glacial epoch, and the advance of the ice from the north, cut off retreat to the Old World species, and gradually hemmed them in over the southern portion of the continent, where all forms of life were compelled to readjust themselves to new conditions. The struggle for existence probably resulted, first, in the extinction of those South American species which had invaded North America during the warmer climate of later Tertiary times; since the more hardy emigrants from the north would have the advantage from the similarity in climate in the southern United States during the Glacial epoch to that about the poles, where they had flourished immediately before. With the withdrawal of ice to the north, the struggle of the animals with the conditions of existence began anew, and the mammoth and some others found themselves unable to cope with the changes to which they were compelled to adjust themselves. From the abundance of remains of these animals found in the peat-bogs of kettle-holes and in the glacial terraces of gravel and loess, it is evident that they followed close upon the retreating ice-front, and some of them continued the retreat to the Arctic Circle, where they still live and flourish; while others, like the elephant and mastodon, perished. 
Few things are better calculated to impress the scientific imagination than this dispersion and final extinction in North America of so many large animals native to the Old World; while some of them, like the horse, were admirably adapted to the present conditions, as is shown by their rapid increase since their introduction after the discovery of America by the whites. In preceding pages we have already seen that man himself participated in this struggle with the new conditions introduced by the Glacial epoch on this continent, and that, in company with the mammoth, walrus, and other arctic species, he followed up the retreating ice both upon the Atlantic coast and in the Mississippi Valley. Whether, like some of his companions, he was unsuccessful in the contest, is not certain, though there is much to be said in favor of the theory that the Eskimos of the north are the lineal descendants of the preglacial men whose implements are found in $\mathrm{New}$ Jersey, Ohio, and Minnesota.

Mr. Darwin early called attention to the more general evidence of a destruction of life during the Quaternary epoch in the southern hemisphere. During his voyage around the world in the Beagle, in 1833 , he encountered in Buenos Ayres the clear evidence which that region furnishes of the sweeping changes in forms of animal life which have taken place everywhere in 
recent geological times. At the time of the discovery of America by Columbus, the horse was entirely absent from the continent; but in those South American plains, where now immense herds of this animal run wild, and where it is no figure of speech to say that beggars ride horseback, there is abundant evidence that the horse, with a large number of immense quadrupeds associated with him, lived and flourished up to recent geological time, and then mysteriously disappeared. Among these companions of the horse in South America were the mastodon, the megatherium, the megalonyx, a species of camel, the toxodon, and a hollow-horned ruminant closely allied to the European cattle. By comparison it will be seen that these are substantially the same species of animals which characterized North America at this same period, and whose bones are found in the recent geological deposits of California, of the Rocky Mountain plains and in Eastern United States.

Commenting upon the cause of this, Darwin remarks :-

"We do not steadily bear in mind how profoundly ignorant we are of the conditions of existence of every animal, nor do we always remember that some check is constantly preventing the too rapid increase of every organized being left in a state of nature. . . . If asked how this is, one immediately replies that it is de- 
termined by some slight difference in climate, food, or the number of enemies, yet how rarely, if ever, we can point out the precise cause and manner of action of the check! We are therefore driven to the conclusion that causes generally quite inappreciable by us determine whether a given species shall be abundant or scanty in numbers."

After a careful survey of the facts relating to the extinction of species in post-Tertiary time, Professor Alfred Russel Wallace, in the first volume of his great work "The Geographical Distribution of Animals," makes the following remarks, specially pertinent to our subject:-

"The first, and perhaps the most startling fact brought out by our systematic review, is the very recent and almost universal change that has taken place in the character of the fauna, over all the areas we have been considering; a change which seems to be altogether unprecedented in the past history of the same countries as revealed by the geological record. In Europe, in North America, and in South America, we have evidence that a very similar change occurred atout the same time. In all three we find, in the most recent deposits-cave-earths, peat-bogs, and gravels-the remains of a whole series of large animals, which have since become wholly extinct or only survive in fardistant lands. In Europe, the great Irish elk, the Machairodus and cave-lion, the rhinoceros, hippopota- 
aus, and elephant;-in North America, equally large felines, horses and tapirs larger than any now living, a llama as large as a camel, great mastodons and elephants, and abundance of huge megatheroid animals of almost equal size;-in South America these same megatheroids in greater variety, numerous huge armadillos, a mastodon, large horses and tapirs, large porcupines, two forms of antelope, numerous bears and felines, including a Machairodus, and a large monkey, - have all become extinct since the deposition of the most recent of the fossil-bearing strata. This is certainly not a great while ago, geologically; and it is almost certain that this great organic revolution, implying physical changes of such vast proportions that they must have been due to causes of adequate intensity and proportionate range, has taken place since man lived on the earth. This is proved to have been the case in Europe, and is supported by much evidence both as regards North and South America.

"It is clear that so complete and sudden a change in the higher forms of life, does not represent the normal state of things. Species and genera have not, at all times, become so rapidly extinct. The time occupied by the 'Recent period,' that is the time since these changes took place, is, geologically, minute. The time of the whole of the post-Pliocene period, as measured by the amount of physical and general organic change known to have taken place, is exceedingly small when compared with the duration of the Pliocene period, and still smaller, probably, as compared with the Miocene. 
Yet during these two periods we meet with no such break in the continuity of the forms of life, no such radical change in the character of the fauna (though the number of specific and generic changes may be as great) as we find in passing from the post-Pliocene to recent times. For example, in Certral Europe numerous hyenas, rhinoceroses, and antelopes, with the great Machairodus, continued from Miocene all through Plicene into post-Pliocene times; while hippopotami and elephants continued to live through a good part of the Pliocene and post-Pliocene periods,- and then all suddenly became extinct or left the country. In North America there has been more movement of the fauna in all the periods; but we have similar great felines, horses, mastodons, and elephants, in the Pliocene and post-Pliocene periods, while Rhinoceros is common to the Miocene and Pliocene, and camels range continuously from Miocene, through Pliocene, to post-Pliocene times;- when all alike became extinct. Even in South America the evidence is, as far as it goes, all the same way. We find Machairodus, Equus, Mastodon, Megatherium, Scelidotherium, Megalonyx, and numerous gigantic armadillos, alike in the caves and in the stratified Tertiary deposits of the Pampas,- -yet all have since passed away.

"It is clear, therefore, that we are now in an altogether exceptional period of the earth's history. We live in a zoologically impoverished world, from which all the hugest, and fiercest, and strangest forms have recently disappeared; and it is, no doubt, a much better 
world for us now they have gone. Yet it is surely a marvelous fact, and one that has hardly been sufficiently dwelt upon, this sudden dying out of so many large mammalia, not in one place only but over half the land surface of the globe. We cannot but believe that there must have been some physical cause for this great change; and it must have been a cause capable of acting almost simultaneously over large portions of the earth's surface, and one which, as far as the Tertiary period at least is concerned, was of an exceptional character. Such a cause exists in the great and recent physical change known as the "Slacial epoch"' (pp. I 49-I5I).

So far we have considered the facts concerning the Glacial epoch which relate merely to the northern hemisphere. The southern hemisphere also had its glacial epoch. A vast area surrounding the south pole is now enveloped in ice to even a greater extent than is Greenland, in the vicinity of the north pole. The southern part of South America still maintains a great array of mountain glaciers which are mere remnants of streams of ice that formerly deployed over the adjoining plains, and filled the channels of its neighboring archipelagoes. New Zealand, also, bears witness to a recent great enlargement of the glaciers which are still an attractive element in its mountain scenery.

Whether the Glacial epoch in the southern hemi- 
sphere was contemporaneous with that in the northern hemisphere is a matter somewhat in question. But the evidence strongly indicates that it was. If so, the estimates which we have made concerning the influence of the accumulation of ice during the Glacial epoch upon changes of land-level, and of the amount of water abstracted from the ocean, must be greatly increased, and the argument bearing on the influence of the Glacial epoch in so disturbing the conditions of animal life as to produce the extermination of species detailed above would be greatly strengthened. Indeed, Mr. Thomas Belt, one of the acutest students of the general influences of the Glacial epoch, supposing that the Ice period was simultaneous in both hemispheres, calculated that the vast amount of water abstracted from the ocean, and locked up in mountains of ice around the two polcs, would lower the general water-level about two thousand feet.

\section{SUMMARY AND CONCLUSION.}

From this survey of facts, it appears that the supposition of a wide-spread submergence of Europe and Asia which continued for but a brief period and occurred since man came into the world, so far from presenting any insuperable difficulties to the wellinformed geologist, relieves him from a great number 
of difficulties, and gives a reasonable explanation to a large and accumulating class of facts which refuse any other explanation. In conclusion, it will be profitable briefly to state the theory anew, and summarize the facts so readily resolved by it. The scientific supposition in conformity with the general statements of the Bible concerning the Noachian Deluge would be about as follows:-

In connection with the instability of the earth's crust accompanying, and probably caused by, the accumulations of ice during the Glacial epoch and its subsequent melting, with the return of the water to the ocean bed. there was a wide-spread depression of Europe and of Northern, Central, and Western Asia, which, though gradual at first, culminated in a catastrophe of more rapid subsidence, foilowed by a still more rapid emergence of the continents, with numerous successive sudden uplifts over various portions of the submerged area. Such a continental subsidence, amounting to about fourteen hundred feet in Western Europe and about three thousand feet around the heaviest continental masses of Central Asia, would fill the Jordan Valle! with oceanic water; would temporarily convert all European Russia, except the Ural Mountains, in company with the great Aral-Caspian depression and all 
Western and Northwestern Siberia, into a sea; would make Lake Baikal an arm of the ocean, and would let oceanic water through the Sungarian depression, southeast of Lake Balkash, into the Desert of Gobi, and there fill a basin in the center of Asia larger than the Mediterranean Sea. Corresponding results would naturally follow in the entire valley of the Euphrates and about the borders of Armenia. 'This depression of the land, followed by a spasmodic emergence, would readily account for the following puzzling facts:-

I. The rubble drift of Great Britain and Western Europe, with its widely dispersed boulders from local elevations which were not centers for the accumulation of glacial ice, and which could not have generated local streams of water sufficient to produce the results.

2. The filling of the numerous ossiferous fissures in Western Europe with an indiscriminate mixture of the separate bones of widely diverse species of animals, mingled with angular fragments of rock and with earth without stratification, and containing occasional stone implements made by the hand of man. These could not have been filled gradually, because there are no entire skeletons of animals, and none of the bones are gnawed. But they were evidently filled by the indiscriminate action of a movement of water acting from above, and sweeping everything before it. 
3. The distribution of loess over not only the elevated portions of the continent, but over the highest elevations in such islands as that of Guernsey, in the English Channel, separated by many miles from the continent.

4. The enormous accumulations of the bones of hippopotami in the cave of San Ciro, near Palermo, on the Island of Sicily, where whole herds of this animal, which now lives only in Southern Africa, evidently sought refuge from rising water in an extensive cave at the base of the rugged cliffs of Monte Grifone.

5. The recent silting up of the Jordan Valley, resulting in a vast accumulation of fine sediment, in some places hundreds of feet in thickness, and forming terraces and shore-lines up to a level of seven hundred and fifty feet above the Dead Sea. The recentness of this accumulation is evident from the fact that only a limited amount of it has yet been washed down into the Dead Sea to fill it up. The supposition that this former enlargement of the area of water in the Jordan Valley was directly due to the Glacial epoch is without evidence, as no signs of former glaciers' appear in the southern portion of the Lebanon region. The Lebanon glacier at the head of the Kadisha River, north of Beirut, was, very likely, a result of the increased pre- 
cipitation incident to this increased expanse of water.

6. The accumulation of extensive beach gravel of recent date at an elevation of seven or eight hundred feet above the ocean at various places around the Black Sea.

7. The accumulation of extensive gravel deposits in the northern part of the Lena Valley and adjacent country, several hundred feet above the ocean, containing fresh vegetal deposits and the bones of the mammoth.

8. The existence of Arctic seal in Lake Baikal, two thousand miles from the ocean, and 1,680 feet above it.

9. The many geological evidences of a recent great extension of water over the region now generally known as the Desert of Gobi.

Io. The historical Chinese tradition of the existence of such a vast body of water in the same region, known as the Han Hai.

I I. The recent great climatic changes which have taken place in Central Asia, indicated by the freshness of the water in the Caspian and Aral seas and Lake Balkash, and by the former vastly increased volume of the ancient Oxus and Jaxartes rivers, and of numerous other streams coming down from the mountains of Central Asia. For, only the temporary inclusion of 
such an interior sea as would be formed in the Desert of Gobi would furnish the required evaporating surface to secure the enlarged rainfall implied; while its gradual desiccation would bring about the return of the present arid conditions, thus furnishing a perfect solution of one of the most complicated problems of climatic changes that have ever been -presented, accounting for all stages in the progress of events, even the limited enlargement of the glaciers which formerly existed in the surrounding mountains.

12. The constancy with which the pressure of population has tended to disperse the tribes and races which have occupied Central Asia. To some extent this may have been due to the natural tendency of man to increase in geometric ratio, but, doubtless, partly to the loss of fertility consequent upon the diminution of rainfall, of which there are innumerable signs.

13. The final distribution of loess in broad, level, terrace-like belts bordering both Turkestan and Northwestern China; for, however much wind may have had to do in slowly accumulating the material about the bases of the mountains, it is clear that some more general force than local streams or any other slowly acting cause has determined a large part of the final readjustment of the material. 
I4. The occurrence of human remains in connection with those of extinct animals of the Glacial epoch at Kief, in Southern Russia, six hundred feet above the sea, and fifty feet below the continuous deposit of loess which covers the region.

15. The wide-spread traditions of a flood found among the peoples of nearly every portion of the globe.

I6. The more definite and restrained account, evidently free from absurd legendary accretions, which occurs in the book of Genesis.

17. The great destruction of animal species which were early companions of man during and immediately after the Glacial epoch.

\section{OBJECTIONS ANSWERED.}

In conclusion, we may reply to numerous objections that may arise, by quoting a few paragraphs from Professor Prestwich's closing remarks:-

"A preliminary objection to a submergence of the character described in the foregoing pages, that will no doubt occur to many, must not be passed over in silence. I allude to the entire absence of marine remains in the different phases of the rubble drift over the area supposed to have been submerged. In reply, it has to be observed that for marine remains to have been located on the submerged land, certain conditions would be indispensable. In the absence of those conditions, we 
could not expect to meet with such remains. It is not to be assumed, because the waters of the sea have for a time covered the land, that marine remains should be found there. If the submergence were slow, the advance of the waters would not have force sufficient to carry before them any of the objects on the shore; or, if any living object were so floated, the turbidity and deoxydized state of the waters resulting from the uprooting of the surface soil with its vegetable matter would be fatal to animal life, and their remains, if any, would decay on the surface and be lost.

"But it may be asked, Why after the submergence, and before the return upward movement, should not the fauna from adjacent undisturbed areas have migrated on to the submerged land surface? This would no doubt have taken place had the submergence been of long duration; but, short as the general evidence leads us to suppose it to have been, such a migration was not possible. The muddy state of the waters would also for a time be a hindrance to the existence of animal life.

"The physical evidence is to the effect that the advancing waters had little erosive power, since they failed to destroy the beaches over which they passed, or to wash away the dunes or blown sands which overlie the raised beaches on the north coast of Devon and Cornwall. At the same time, the advance of the waters was progressive, as, had they been long stayed, they would not only have destroyed these surface features, but would have left their mark on the land surface, either in the form of a beach, or by a line of water- 
erosion on the rocks at the level at which they remained for the time stationary. The inference is that the waters rose slowly and continuously, charged merely with the mass of sediment derived from the soil and rocks over which they passed. 'This sediment, which was deposited either at the high tide of the waters or at intervals as they subsided, forms the mantle of loess so conspicuous in Central Europe, and of the slighter deposit of red earth so widely spread on the lands bordering the Mediterranean.

"That there was but a short lull when the submergence reached this stage is to be inferred from the fact that the rubble drift rests immediately on the raised beach. Had there been any long interval, there would have been some form of sedimentary deposit between the beach and the head or the blown sands; but there is none. With the commencement of the elevatory movement, effluent currents at once came into play, and according to their varying velocity, carried down, sometimes the surface soil or the freshly deposited loess, and at others the coarse surface detritus. The conclusion from this is that the upheaval was by fits and starts, or rather by a continuous movement, sometimes very slow and at others more or less rapid, and ending with one of greater rapidity. Where hollows or cavities existed on the surface, the débris fell into them. Open fissures were filled to the brim by the passing débris, while the current, acting as a broom, brushed off any projecting débris on the top of the fissures, and 
at the same time swept bare the adjacent more exposed surfaces.

"We judge from these conditions that the submergence took place slowly and continuously. I do not mean by slow, that it took years, but so slow possibly as on the whole to be hardly apparent to the spectator of the scene, or, may be, it would give him the reverse impression, such as that experienced when one's own train at a railway station ma!'es a noiseless start and another train is standing still alongside, that that train was moving and your own stationary, or vice v'ersa. So, in this case, the land would seem, to one standing on it, as though it were immovable and stationary, and that it was the waters that were in movement and ising." 4 


\section{GENESIS AND SCIENCE.}

IN writing upon this subject at previous times, ${ }^{1}$ ! have dwelt, I now believe, somewhat too exclusiveiy upon the adaptation of the document to the immediate purpose of counteracting the polytheistic tendencies of the Israelites, and through them of the world. With this in view, the following language was used:-

"It was not modern science with which the sacred writers wished to be reconciled, but polytheism which they wished to cut up root and branch, that gave rhetorical shape to the first chapter of Genesis. Followed by the traditions of polytheistic ancestors, tainted by the polytheistic conceptions of the Egyptian people from whom they had escaped, and surrounded by the civilized worshipers of Baal and Ashtaroth, the children of Israel needed to have the unity of God emphasized. Historically it can be shown that the first chapter of Genesis has had more influence in disseminating correct views of the divine unity and personality than al! other literature put together. Now what does it say? Why, it denies the plurality of gods. It denies it both in general and in detail. It affirms, in general, that God-the God of Israel-created the heavens and the 
earth. The writer then descends to particulars, and affirms (I) tha. it was this same one and true God who created the light which some ignorantly adored as itself divine; (2) it was also the same God that ruled both the sky and the earth. (3) The fruitfulness of the rarth, which some worship as the manifestation of a particular divinity, is also the if of Israel's God. (4) The sun and moon are not to be worshiped; God created them. (5) Why worship the sacred bulls and cats of Egypt, when it was God who created every living thing-the beast of the field, as well as the fowi of the air, and the fish of the sea? (6) Finally, God created man, and set him over all things he had made. Why should the lord of the creation bow down to stocks and stones?

"Such, to the contemporary of Moses, was the purport of this most remarkable 'proem' to God's revelation of man's condition and ground of hope. It should be remembered that the first chapter of Genesis had the same editorial supervision with the ten commandments. When thus we consider it as a protest against polytheism, and an enforcement of the first two commandments, it seems an impertinence to endeavor to find all modern science in the document, however easy it may be for science to find shelter under the drapery of its rhetoric."

If this were all that could be said in justification of the literary form of Genesis, it would be ample. But prolonged attention to the subject has forced the 
conviction that much more than this can be and needs to be said. On the former theory, there would have been no necessity for the adoption of any particular order in the arrangement of the facts of creation. But, upon inspection, there appears in this account a systematic arrangement of creative facts which corresponds so closely with the order of creation as revealed by modern science that we cannot well regard it as accidental. So remarkable is this coördination between the inferences of science and the statements of Genesis, that they lead such a competent and cautious geologist as Professor J. D. Dana to pronounce it utterly unexplainable except on the theory of the divine inspiration of the author of Genesis. The following is his em. phatic language, written shortly before his death:-

"Geologists vary much as co their views on this chapter [Gen. i.]; and some will take it literally, affirming that it is a mere fable, no better than other fables in ancient history. We would ask of all such (as well as of the nature-doubting exegete) a reconsideration of the question; and if they have doubts with regard to the authenticity of the Bible itself, they may perhaps be held, after a fair examination of the narrative, and a consideration of the coincidences between its history and the history of the earth derived from nature, to acknowledge a divine origin for both; and to recognize the fact that in this introductory chapter its 
divine author gives the fullest endorsement of the book which is so prefaced. It is his own inscription on the title-page." 2

It should be noted that this utterance of Professor Dana is neither an opinion hastily formed, nor the mere reiteration of views held at an earlier period in his life. Nearly thirty years before, he had published extensively upon this subject in the Bibliotheca Sacra, having then recently been convinced of the general truth of this view, through his acquaintance with the learned and devout Professor Guyot. During this period, Professor Dana's mind had been remarkabls active. He had continued to edit the American Journal of Science and to teach his classes in college; he had prepared and published numerous editions of his "Manual of Geology," and he had continually faced the question whether the tendency of advancing science was to support or discredit his earlier published views. The result is given in the words just cited. As just remarked, these were not hastily written, but form the close of a long article, prepared expressly to give to the world what they had long been asking,- - a formal and full statement of the result of his maturest study and reflection. We are not at liberty to let such an utterance of so competent a scientific authority upon this subject count as of small weight. 
The facts upon the scientific side, as stated by Professor Dana in the article referred to, are as follows: According to a combination of evidence which cannot well be disputed, the stages of the world's development nave been these:-

I. When the material elements of the universe were first brought into existence, they were diffused and formless, that is, they were not collected to form the suns and planets and satellites, which now in such majestic circles wheel around each other in space. The nebular hypothesis is already a doctrine of science.

2. One of the first results of the collecting together of this diffused nebulous matter would be the creation of light, which, like heat and electricity, is nothing else than a mode of motion.

3. There is no reasonable doubt that the earth was at one time a molten mass, with a temperature of $2, \mathrm{OOO}^{\circ}$ above zero, and hence for a long time, until th: surface of the earth should have cooled down to a temperature not greater than $600^{\circ}$ above zero, there could have been no water upon it, and it must have been surrounded by a cloud of vapor of immense thickness and density, which would have been broken up and removed only after the lapse of untold ages.

4. The appearance of plants upon the earth preseded that of animals. This is proved both by the 
nature of the case and by weighty positive evidence: (I) So far as is known, animals are not able directly to assimilate mineral matter. Animals are either compelled to feed upon plants or upon one another; while plants draw their nutriment directly from the earth and air. (2) Plants will also endure a much higher temperature than any known animals. Some forms of plant life will even survive a temperature of $220^{\circ}$ above zero, that is, they would not be destroyed by boiling water. (3) Again, the lowest forms of animal life (certain rhizopods) exhibit such marvelous attributes of instinct and choice as to separate them at once from all forms of plant life. Every argument, therefore, in support of the general fact of evolution in nature, points to the nrigin of plant life before that of animal life. (4) In the earliest known sedimentary rocks, namely, the archæan formations of Canada, there are extensive deposits of graphite, or lilack lead. Now it should be remembered that this, though called "black lead," is not lead at all, but pure carbon, or coal, and the probability that it is of vegetable origin, like other coal, is very great. It is true that distinct remains of plants have not yet been found in archæan rocks; but these rocks have been so metamorphosed, or changed, by heat, that all direct relics of distinct forms of plant life must very early have been destroyed. Still, in Rhode Island 
and in Worcester, Mass., this so-called black lead is found so related to the coal deposits of that vicinity that there can be little doubt that it is itself transformed coal. Thus the evidence is cumulative and well-nigh irresistible, that plants were created before animals.

5. The order in which the various forms of animal life have appeared on the earth is as follows: The sea was first peopled with animals not having a backbone, such as the various kinds of shell-fish. Fishes with a backbone come next. After fishes, the next order of animals which appears in geological strata are Amphib. ians, which, like the frog, can live both in the wate: and out of it. After the amphibians come the Reptiles. or creeping things. So numerous are the reptiles in this age, and so remarkable are their size and shape, that a whole geological period before the introduction of the class of animals with which man is most closely allied is called by Agassiz the Age of Reptiles.

As to the date of the origin of Birds, the scientific evidence is somewhat indeterminate; but there can be little doubt that their advent preceded that of the earliest mammals. The Mammals are those animals whose young are born alive and are suckled by their mothers. The earliest of these, however, like the opossum and kangaroo, are not true mammals, since 
their young are not able to move about independently of their mothers, but are carried about by them in a pouch until partially grown. True mammals, like the cow, the horse, the dog, the cat, and the ape, appear only at a much later age, closely bordering upon that of Man. Without question, man is the last of this series, and fitly closes the developing scheme of natura? creation as unfolded to us in the leaves of the geolog.ical record.

Such, upon the scientific side, is the line of the parallel with which the story of creation in Genesis is to be brought into comparison. The question at issue is, Is the parallel between the two records such as to exclude chance and to compel us to acknowledge the presence of design? The more closely one studies the problem, the less can he be satisfied with any theory that rules out the idea of a desig in this parallelism. It could not have been a matter of mere chance that a writer should describe the order of creation so nearly in accordance with the discoveries of modern science.

In proof of this statement, let us bring the Mosaic line of the parallelism briefly before us.

I. According to Genesis, the universe was brought to its present condition not instantaneously, but by progressive stages, corresponding in a remarkable de 
gree to the actual order as inferred by modern science. In the first place, it is surprising that, in the unscientific age in which the book of Genesis originated, a writer should have spoken of the creation of light as taking place before the creation of the sun and moon and stars. But this corresponds with recent discoveries of science which have ascertained that light is the result of chemical action, and so must really have been one of the earliest accompaniments of the creative or developing process, and must have long preceded that segregation of matter which constitutes our globe and the solar system.

2. But the second stage as mentioned by Genesis speaks in remarkable terms of the formation of a firmament subsequent to the formation of light, and previous to the appearance of dry land,- - a firmament separating the waters below from the waters above. It would be difficult to choose a brief statement of the case which should more happily express in phenomenal language that stage of creation, brought into view by modern science, in which the nebulous matter became localized, and segregated into revolving systems, such as the astronomer now delights to study. But, according to the writer of Genesis, as well as according to the dicta of science, all this was preliminary to those physical con- 
ditions which would render possible the existence of organic life.

3. According to Genesis, the third stage of progress was marked by the appearance of dry land. Upon the third day, also, close upon the appearance of dry land, occurs the beginning of vegetable life, in which the characteristics by which a living species are distinguished from an inorganic substance are most clearly stated. Inorganic nature has no inherent power of reproduction. But the writer of Genesis describes a living species as one whose seed is in itself, yielding seed after its kind.

It is sometimes objected to this account of the creation of the vegetable kingdom upon the third day, that it describes the higher species of plants, which are introduced only at a much later period, namely, the grass and the fruit-trees; whereas the earliest plants belong to a much older order of the vegetable kingdom. A similar objection is also urged against the account of the creation of the dry land, since that has been going on ever since, new land being formed even at the present day. As a most satisfactory reply to this objection, we can do no better than to quote the language of Dr. E. P. Barrows, who wrote many years ago as follows:"In our view Moses, in describing the creation of 
the vegetable kingdom on the third day, . . . describes neither the creation of the particular existing species as contrasted with the extinct species of former ages, nor of these extinct species as contrasted with the species now existing. But he describes the establishmont of the regetable kingdom in its law's and general forms, which are valid for all the subsequent geological eras. The grand fact revealed is, that on the third day the vegetable world was brought into being under the immutable principles which now regulate its operations. And we ask: Why is not this a fair interpretation of the words, ' and the earth brought forth grass, the herb yielding seed after its kind, and the tree yielding fruit, whose seed is in itself, after its kind?' The reader will notice that the two things made prominent in this account are law', as expressed in the formula, after its kind, and general forms, ' grass,' ' herb,' 'fruittree yielding fruit, whose seed is in itself." ",

Upon the same point, with reference to the creation of birds, Mr. Gladstone has the following pertinent language:-

"No doubt," he says, "there may be a degree of literalism which will even suffice to show that, as 'every winged fowl' was produced on the fourth day of the Hexaemeron, therefore the birth of new fowls continually is a contradiction to the text of Genesis. But does not the equity of common sense require us to understand simply that the order of 'winged fowl,' whatever that may mean, took its place in creation at 
a certain time, and that from that time its various component classes were in course of production?"

4. The fourth grand stage in the creative plan as described by the writer of Genesis relates to the establishment of days and seasons upon the earth, through its relation to the sun and moon. They are then set in the firmament to give light upon the earth, and to rule over the day and over the night, and to divide the light from the darkness. Up to this point we may suppose, from scientific data, that there was no darkness upon the earth; that, though the earth was surrounded by clouds, they were luminous clouds, everywhere shining, like the aurora of the North, from the electrical disturbances, which then must have been so abundant. The plants of the coal period were not necessarily dependent upon either the light or the heat of the sun. It is only the higher forms of plants and animals that are especially adapted to this periodicity in the return of both heat and light which characterizes the present order of things. When the earth's swaddling-band of clouds was all one blaze of electric light, the sun did not divide between the darkness and the light, and the moon and the stars did not rule over the night. This turn to the meaning of the words seems fully justified by the frequent repetition of the object for which the sun and moon and stars were 
"set in the firmament" (ver. 17). This was to be for signs and seasons and days and years. This they could be only when they became visible from the surface of the earth.

5. The fifth grand stage marks the introduction of such animals as swim in the water and fly in the air. Here, too, though the general correspondence with scientific inferences is marked, we are not compelled to suppose that every class of winged fowl and every class of sea monster were actually brought into existence during that period; for, in so brief and so summary an account, we should naturally expect that some things of the same class would be referred to by anticipation.

6. The sixth stage, according to the writer in Genesis, brings us to the introduction of those forms of life most closely connected with man, namely, the cattle and beasts of the earth. Here, also, was the appropriate place to mention the creeping things, since the age of reptiles is joined so closely to that of the mammalian forms of animal life. For brevity's sake and completeness, they are referred to by retrospect, in order, so to speak, to glean the field, as the higher forms of fish are referred to by anticipation in the account of the fifth day. It is a capital error to impose upon so rhetorical and brief an account as this a literalism of interpretation which would befit only an extended scientific 
treatise. It is only in general outline that correspondence can be expected. Language does not permit all truth to be compressed into a single paragraph.

It remains to discuss the question whether it is allowable to consider the word "day" in the first chapter of Genesis as the equivalent of long periods of time. Upon the propriety of doing this, we need do little but quote the words of Dr. Driver. While distinctly rejecting, on what he mistakenly supposes to be scientific grounds, the foregoing plan of harmonizing Genesis with geology, and holding that the word "day" must signify a literal day, Dr. Driver still concedes all that is necessary upon the point. His language is as follows :-

"At the same time the possibility must be admitted that the writer may have consciously used the term day figuratively, fully aware on the one hand that the work of the Creator could not be measured by human standards, but on the other hand desirous of artificially accommodating it to the period of the week. In spite of the phrases evening and morning, which seem to imply literal days, the supposition that the narrator meant his 'days' as the figurative representation of periods should not, as the present writer ventures to think, be ruled as inadmissible."

"The question, however, is not so much what the 
word means, as whether or not it may have been applied figuratively by the writer. It seems reasonable to admit that this may have been the case. The 'morning ' and 'evening' will then be part, not of the reality, but of the representation." +

In these remarks, Dr. Driver only states a principle which is so clear as not to need repetition or emphasis, except for the fact that ill-advised statements upon the subject have frequently been put forward by persons in prominent positions who assume to speak with authority. The truth is, as Dr. Driver clearly perceives, that the meaning of such terms is not a question of mere etymology or Hebrew grammar, but of the broader questions of rhetoric, upon which the judgment of any well-informed literary person is of about as much value as that of a specialist in Hebrew. Broad-minded scientific men like Winchell, Dawson, Dana, and Guyot cannot, by good rights, be warned off from this field, and men of wide literary tastes and political experience like Gladstone are in their appropriate province when estimating, from general considerations, the character of such a document as that containing the cosmogony of Genesis.

The words ef Gladstone on this point are those of experience and wisdom:-

"We do not hear the authority of Scripture im- 
peached on the ground that it assigns to the Almighty eyes and ears, hands, arms, and feet; nay, even the emotions of the human being. This being so, I am unable to understand why any disparagement to the credit of the sacred books should ensue because, to describe the order and successive stages of the Divine working, these have been distributed into 'days.' What was the thing required in order to make this great procession of acts intelligible and impressive? Surely it was to distribute the parts each into some integral division of time, having the character of something complete in itself, of a revolution, or outset and return. There are but three such divisions familiarly known to man. Of these the day was the most familiar to human perceptions; and probably on this account its figurative use is admitted to be found in prophetic texts, as, indeed, it largely pervades ancient and modern speech. Given the object in view, which indeed can hardly be questioned, does it not appear that the 'day,' more definitely separated than either month or year from what precedes and what follows, was appropriately chosen for the purpose of conveying the idea of development by gradation in the process which the Book sets forth?" 5

In view of all these facts, we must deem it by no means a profitless employment to study the lines of harmony that are so manifest between the first chapter of Genesis and the record of creation as found in the inferences of modern science. It is not easy to believe 
: hat this scheme of reconciliation is altogether the child of the prepossessions of students either of the Bible or of nature. It is true that the evidence is not demonstrative, in the strict sense of that word, but certainly it is impressive, and raises so high a degree of probability in favor of the divine guidance of the writers of the first chapter of Genesis, as materially to sustain the respect with which the Bible has been regarded so long by the Christian public.

in the words of President Edward Hitchcock, written many years ago,-

"It is not necessary that we be perfectly sure that the method which has been described, or any other, of bringing geology into harmony with the Bible, is infallibly true. It is only necessary that it should be sustained by probable evidence; that it should fairly meet the geological difficulty on the one hand, and do no violence to the language or spirit of the Bible on the other. This is sufficient, surely, to satisfy every philosophical mind, that there is no collision between geology and revelation. But should it appear hereafter, either from the discoveries of the geologist or the philologist, that our views must be somewhat modified, it would not show that the previous view had been insufficient to harmonize the two subjects; but only that here, as in every other department of human knowledge, perfection is not attained, except by long-continued efforts." 。 
In conclusion, it is in place to call more particular attention to the scope of the argument which may properly be drawn from the wide range of facts presented in this volume, and to note that the validity of the argument is not impaired by the fact that only a small portion of the biblical history has been brought under review. Necessarily the most of the history is such as cannot be directly substantiated by outside evidence, and can be accepted only upon the strength of our general confidence in the witnesses. The facts here adduced go far towards establishing confidence in the integrity both of the original witnesses and of thos: who have transmitted the testimony to us. To a remarkable extent in this field, as elsewhere, the apparent improbabilities of the Bible are found to be capable of verification. From every quarter, unexpected light is breaking in upon us from apparent darkness. The strength of the evidence of the truth of the historical statements in the Bible is, therefore, not diminished, but rather is increased, by modern scientific investigation.

The historical narratives which we have brought under review are so fitted into peculiar and little understood physical conditions that any attempt to expand the simple record of the phenomena would have 
involved the writers in statements concerning such an inexplicable network of physical causes and effects that they would have inevitably been led into extravagant and grotesque representations. The freedom of the sacred record from such extravagance and grotesqueness where the liability to such error was at its maximum, certainly goes far to establish its credibility in those matters in which corroborative testimony is unattainable. The competence of a witness where his statements can be verified throughout an intricate environment is the best guarantee we can have of his competence when, uncorroborated, it leads us into unknown fields. Those who reject the testimony of the sacred writers certainly do so in the face of evidence that is ordinarily accepted as conclusive. 


\section{APPENDIX.}

\section{CHAPTER I.}

Note I, p. I4.-This subject forms the burden of Butler's "Analogy," a classic work that is too much neglected by the present generation.

"In questions of difficulty, or such as are thought so, where more satisfactory evidence cannot be had, or is not seen, if the result of examination be, that there appears upon the whole, any the lowest presumption on one side, and none on the other, or a greater presumption on one side, though in the lowest degree greater. this determines the question, even in matters of speculation; and, in matters of practice, will lay us under an absolute and formal obligation, in point of prudence and of interest, to act upon that presumption, or low probability, though it be so low as to leave the mind in a very great doubt which is the truth. For surely a man is as really bound in prudence to do what upon the whole appears, according to the best of his judgment, to be for his happiness, as what he certainly knows to be so. Nay, further, in questions of great consequence, a reasonable man will think it concerns him to remark lower probabilities and presumptions than these; such as amount to no more than showing one 
side of a question to be as supposable and credible as the other; nay, such as but amount to much less even than this. For numberless instances might be mentioned respecting the common pursuits of life, where a man would be thought, in a literal sense, distracted, who would not act, and with great application too, not only upon an even chance, but upon much less, and where the probability or chance was greatly against his succeeding" (pp. 30-3I).

Note 2, p. 22.--The question of the genuineness of these extracts is exhaustively considered by Rev. Alexander Mair, D.D., in the first volume of the Fourth Series of the Expositor (pp. 366-381), from which it appears that General Montholon (who was the constant companion of Napoleon on St. Helena, and to whom an early copy of the book from which these quotations are made, was sent, in $18+1$, by Chevalier de Beauterne) wrote to the author, "I have read with a lively interest your work, Sentiment de Napoleon sur le Christianisme, and I do not think it possible to express better the religious beliefs of the Emperor." On the other hand, General Bertrand repudiated the sentiments, and spoke of them as a "libel," adding that there was not one word of truth in them, saying further, "Neither in France, nor in the army, nor in the Island of Elba, nor in St. Helena, have I heard Na- 
poleon discussing the existence or the divinity of Jesus Christ" (p. 37I).

The explanation of this contradiction seems to be that Napoleon talked more freely with General Montholon than he did with General Bertrand. The latter's denial, therefore, has little weight. There can be ro reasonable doubt of the substantial correctness of these reported conversations of the Emperor.

Note 3, p. 22.-For this extract, and many more of similar tenor from various authors, see Philip Schaff's "Person of Christ."

Note 4, p. 24.-For full proof of this statement, see my "Scientific Aspects of Christian Evidences," chap. ix.

After long contention for the contrary opinion, even Harnack was at last compelled, by the discovery of 'Tatian's "Diatessaron," and various other lost works, to admit that the New Testament writings all belonged practically to the first century.

"The oldest literature of the Church in all main points and in most details, from the point of view of literary criticism, is genuine and trustworthy. ... The chronological succession in which tradition has arranged the original documents of Christianity is, in all essential points from the Epistles of St. Paul to the writings of Irenaeus, correct, and compels the historian 
to keep clear of all hypotheses concerning the course of events which conflict with this succession."

NoTE 5, p. 30.-For a very effective presentation of the evidence that written documents were in use among the Israelites from the earliest times, see Orr's very able work "Problems of the Old Testament," pp. 7I-8I.

CHAPTER II.

Note I, p. 40.--See article "Primeval Chronology," Bibliotheca Sacra, April, i890, pp. 285-303.

Note 2, p. +2. -This whole subject is treated in a convincing and masterly manner by Professor Willis J. Beecher in the Bibliotheca Sacra for April, I 899. His statement of the case is self-eridencing:-

"The completed Old Testament book contains more than merely the extracts which the final authors have made from their sources. It gives us their judgment, either expressed or implied, in regard to the relations between the sources, and the proper interpretation of the sources.

"In proportion as the book is held to differ from the original sources, in just that proportion does the study of an Old Testament book include much that is not included in the original sources. The men who put the sources together had a very important part in the authorship of the books. To ignore their part by paying exclusive attention to the sources is contrary to all laws of scientific procedure." 
"... To assume that the original sources of the Old Testament book are the nucleus within which inspiration is confined is contrary to all the evidence. The holy men that spake as they were moved by the Holy Ghost were as often the secondary as the primary authors of the books. To neglect the book as a whole, confining attention to the supposed original sources, is, from the point of view of the doctrine of inspiration, to neglect a part of the revealed mind of the Spirit."

"... Some of our contemporaries are accustomed to stigmatize the men who put the Old Testament sources together as 'uncritical.' But these men, whoever they were, critical or uncritical, constructed literary products that have attracted more attention than any other literature for from twenty-two to thirtythree centuries. How many living men are there, highly gifted critically, whose work upon other men's writings will command world-wide attention twentythree centuries hence? These secondary authors of the Old Testament books did their work, twenty-two centuries and more ago, in such a way that hundreds of scholars now living, including the very men who count them uncritical, find it worth while to devote thousands of years of skilled study to the examination of the work they did. In view of this, it is idle to say that their judgment in literary and historical matters is not worth considering. However they may have lacked nineteenth-century culture, the fact that their work is still so thoroughly alive is conclusive proof that they were men of gifts and of sound mind. They had foun- 
tains of information which we have not. In particular, they had the whole of certain sources of which we have only the parts which they transcribed. Whatever any may think as to the question whether they were by inspiration guarded from mistakes, or as to the degree of their trustworthiness, the statements that such men have left on record are at least worthy a deliberate examination. We owe a respectful study to the books as they left them, and not merely to the sources as they found them" (pp. 2i 8-220).

Note 3, p. 4+-According to Sayce,-

"The proclamation of Cyrus shows that he was nc" a Zoroastrian like Darius and Xerxes, but that as he claimed to be the successor of the Babylonian kings, so also he acknowledged the supremacy of Bel-Merodach the supreme Babylonian god. Hence the restoration of the Jewish exiles was not due to any sympathy with monotheism, but was a part of a general policy. Experience had taught him the danger of allowing a disaffected population to exist in a country which might be invaded by an enemy; his own conquest of Babylonia had been assisted by the revolt of a part of its population; and he therefore reversed the policy of deportation and denationalization which had been attempted by the Assyrian and Babylonian kings. The exiles and the images of their gods were sent back to their old homes; only in the case of the Jews, who had no images, it was the sacred vessels of the temple which were restored" (Hastings' Dictionary, vol. i. p. 542). 
Note 4, p. 45--Art. "The Abasement of Nebuchadnezzar," Bibliotheca Sacra, October, 1905, pp. $601-625$.

Note 5, p. 48.-Pusey, in his Lectures on Daniel, has the following pertinent remarks, though he is in error in calling the disease lycanthropy :-

" There is scarcely any stronger internal evidence of truth, than circumstances, on the surface unlikely, which, on careful examination, appear to be in harmony with the rest of the history. And this the more, when the scientific knowledge of that truth belongs to a later age. Thus, in secular history, Herodotus' account of the circumnavigation of Africa is now undoubted, because of the fact of the position of the sun, which one would not have known who had not crossed the line."

"So, in this account of Nebuchadnezzar, if the disease was some form of Lycanthropy, we should have an account of a rare disease, mentioned by no author before the Christian era, with physical facts, not obvious, but in harmony with it; but in any case, and still more remarkably, we have the psychological fact, that one, with a beast's heart, perhaps imagining himself an ox, any how in a very degraded form of insanity, could still pray as a man. ... This is related in Daniel with the simplicity of truth; ignorant scepticism pronounces it impossible; true physics and psychology attest the reality of the description."

An interesting illustration of the way in which a 
writer's personal unfamiliarity with the scenes involved in his descriptions is brought to light appears in Dean Stanley's criticisms upon two poems of Keble's "Christian Year." In the verses for the Third Sunday of Advent, Keble, in describing Lake Galilee, writes,-

"All through the summer night Those blossoms red and bright Spread their soft breasts, unheeding, to the breeze."

In the early editions of the "Christian Year" a note referred to these blossoms as "rhododendrons"; whereas they are oleanders, and the correction is made in later editions. In another stanza the poet speaks of "mountains terraced high with mossy stone," which is a figure familiar enough to a poet living in the moist climate of England, but inapplicable to the bare landscape of Palestine. Again, in the verses on the Seventh Sunday after Trinity, he speaks of Tabor's lonely peak," whereas the Mount of Precipitation, Little Hermon, and Mount Gilboa are all within three miles of it and easily visible.

Note 6, p. 52.-All this is put in a very clear light by Professor IVilson in a learned article in the Bible Student and Teacher for February, , 1906. He says in part:-

"No one knows enough of the reign of Nabonidus 
to assert with confidence, or truthfulness, that the statements of the book of Daniel with regard to Belshazzar may not all be historically true.

"But, how then about his being called in Daniel the son of Nebuchadnezzar, whereas Nabonidus calls him his son? No doubt, if we knew all the circumstances of that time, we could explain this apparent discrepancy with satisfaction. As it is, who knows, first, that Belshazzar may not have been the son of Nebuchadnezzar by blood and the son of Nabonidus by adoption? Or, secondly, that the mother of Belshazzar was not a daughter of Nebuchadnezzar and at the same time the wife of Nabonidus, so that Belshazzar would be the grandson of Nebuchadnezzar, and could in consequence thereof be called, in the manner of the Hebrews and Aramæans, his son? Or, finally, he could be called the son of Nebuchadnezzar, in the same sense that Jehu is called on the Assyrian monuments the son of Omri; or Xerxes the son of Cambyses and Cyrus, by Herodotus in the genealogy of Xerxes given in Bk. vii. II of Herodotus' history, i.e. as his legitimate successor on the throne, without regard to blood relationship."

"If we suppose with Pinches (who, it seems to me, has written best on this matter), that Darius the Mede was the same as Gobryas, the Bible and the monuments will be in entire accord. . .

“ Gobryas was Cyrus' governor (amel pihate su) of Babylon as early at least as the $3 \mathrm{~d}$ day of the $8 \mathrm{th}$. month of Cyrus' accession year. (Annals of Nabon' 
dus, Col. iii. line 20.) He was in command on the I Ith of the same month, when Belshazzar was slain. It is most probable-there is nothing, at least, against the supposition - that he remained in command and at the head of the government, until Cambyses was installed as king of Babylon on the 4 th of Nisan of the following year. The only question, then, is: What would be the title in Hebrew and Aramaic of Gobryas as amel pihate of Babylon? In answer, we can only ;ay, that malkatz and malek (sarah) would be the only suitable words; and that Gobryas could rightly be called by this title as long as he was amel pihate of the city or province of Babylon, i.e. from the $3 \mathrm{~d}$ of the 3th montl of Cyrus' accession's year to the $3 \mathrm{~d}$ of Nisan if his first year."

"But some will say, How do you explain the differ-nce of name? The easiest explanation would be to suppose that an error had crept into the Biblical text. Still, we are by no means shut ip to this explanation. Many kings in ancient, as well as modern, times had ¿wo or more names; especially a pre-regnal and a regnal name. The great Rameses the Second (or Usertesen as Lethe claims), king of Egypt, seems to be the same as the Sesostris of the Greeks. But Sesostris is found perhaps but twice, and then with different spelling, among the almost innumerable titles and monuments of this king. (See 'Le Livre des Rois,' by Brugsch and Bouriant, 444.) So Solomon is the same as Jedediah. But coming nearer to the time of Cyrus, we find that Artaxerxes was called Cyrus before he became king ( Jos. 
phus); that Darius Nothus was called Ochus, before he became king; and the last Darius, Codomannus. Why may not the name Darius have been assumed first of all by Gobryas the Mede, when he became king of Babylon? If we could only be sure as to the meaning of the word Darius, we might understand better, why the name was given or assumed, as a royal or princely appellation. Who knows, that Darius is not the translation of Gubaru? Or, that if, as good authorities claim, the first part of the name is the same as the new Persian dara, 'king,' the name Darius may not mean some such a thing as regulus? Or if the name be derived from the old Persian verb tar, 'to hold,' who knows that it was not originally a title meaning simply 'holder of the scepter'? The title in either case would be appropriate to Gobryas as sub-king of Babylon, and also to Darius, the son of Hystaspes, who was by birth a king, second in rank and race to Cyrus alone. (See 'Behistun Inscripten,' lines 2 and 3.)" (Pages 86-9I.)

Note 7, p. 54--For a very interesting and able discussion of this subject, we are indebted to an article on "Biblical Epidemics of Bubonic Plague," in the Biblic theca Sacra for April, I904, by Edward M. Merrin: M.D., from whom these quotations are made.

Note 8, p. 54.- “Antiq." х. 1. 5.

Note 9, p. 54.- " History:" ii. I+1.

Note 10, p. 56.-According to Dr. Merrins,-

"Almost every feature of this narrative fits in with 
the opinion that it is an account of an epidemic of bubonic plague.

"The symptoms of the disease correspond with those of plague. The sacred historian, not writing a medica' treatise on the subject, mentions only the most characteristic symptoms, - the tumors or plague boils. But this of itself is enough to identify the disease. "No other idiopathic fever attacking a multitude of persons at the same time is characterised by glandular swellings, by carbuncles, and by those severe manifestations of the nervous, sanguineous, and biliary systems which declare themselves in an attack of plague.' A very severe form is chiefly marked by vomiting of blood, as in the outbreak on the Lower Euphrates in 1873 ; and of the Justinian epidemic Gibbon writes: 'In the constitutions too feeble to produce an eruption, the vomiting of blood was followed by a mortification of the bowels.' It is very interesting to observe that, according to Josephus, death came upon the Philistines very suddenly: 'For before the soul could, as usual in easy deaths, be well loosed from the body, they brought up their entrails, and vomited up what they had eaten, which was entirely corrupted by the disease.' In the most terrible form called the 'fulminant,' people are struck down very suddenly, and die before the tumors have time to develop. The inhabitants of the city of Ekron were visited by this type. 'And the men of the city that died not [immediately] were smitten with tumors '" (pp. 295-296). 
Note i I, p. 66.--Keil's "Commentary on the Book of Joshua," page 26+. The author discusses this passage in Joshua at great length.

CHAPTER III.

Note I, p. 70.-Brugsch's "History of Egypt," isl. i. p. 304.

Note 2, p. 70.- "The Rational Almanac, tracing the Evolution of Modern Almanacs from Ancient Ideas of Time and suggesting Improvements. By Moses B. Cotsworth, of York, Englind. Published by the Author."

Note 3, p. 74.-Art. "Famine," Smith's Dictionary of the Bible, vol. i. p. 611 .

Note 4, p. 74. -Quoted by Mr. John Ward in

Pyramids and Progress," page 265.

Note 5, p. 76.-Ibid., pp. 266-267.

Note 6, p. 76.-Nature, July 25, I901, page 38.

Note 7, p. 82.- "The Store City of Pithom and the Route of the Exodus," First Memoir of the Egyptian Exploration Fund, 1885. For a popular account, see Amelia B. Edwards's "Fellahs and Explorers," p. 50.

Hengstenberg long ago made a very full presentation of the undesigned correspondence between the sacred narrative and the known facts concerning Egypt, which has been well summarized by President Samuel 
Colcord Bartlett, in his "Veracity of the Hexateuch" (pp. 87-9I).

\section{CHAPTER IV.}

Note I, p. 85.-We are glad to be supported in these statements by so eminent an authority as Dr. William Brenton Greene, Jr.:-

"Finally, what is to be said of the tendency of the attempt to explain many of the events in the Old Testament formerly regarded as miracles as special providence? We may not say that this is a tendency to eliminate the Supernatural from the biblical history. Though not wholly and, therefore, so strikingly supernatural as the miracle, the special providence implies as evidently and as necessarily the supernatural. That the coincidences in which it consists should be the result of chance, rather than of supernatural prevision and combination, cannot be accepted by a reflecting mind. Chance never exhibits purpose, and in all cases the same high and holy purpose. When the ship turns from her course just as a rock looms up before her. it does not weaken our conviction that a pilot is at the helm to learn that the ship has been turned by the pressure of her rudder against the waves. The question is, How came the pressure then and there? and there is no satisfactory explanation but the directing hand of the pilot.

"Nor, again, need the tendency under consideration be hostile to the miraculous. It will not be so long as the reality and the necessity of the miracle are still af- 
tirmed. The number of miracles may be reduced in the interest of correct classification quite as much as in the interest of antisupernaturalism; and if the former be the case, the position of the miracles remaining will be strengthened rather than weakened. In the end, every concession to the truth will add a buttress to the truth. How this should be in this instance, it is easy to see. Nothing is more characteristic of the biblical miracles than the economy with which they are used. This is so, whether we conceive of them as strictly as the present article would do, or loosely. It is still true that they occur only at certain great and decisive epochs in the development of the divine plan of redemption, and that even at these epochs their employment is marked by sobriety and restraint in most striking contrast with all alleged extrabiblical miracles." (Art. "The Relation of the Miracle to Nature." Bibliothec Sacra, July, 1900, pp. 555-556.)

Note 2, p. ioo.--See, also, Dawson's "Egypt and Syria," page 35 .

Note 3, p. IOI.-Nature, August 21, I88+.

Note 4, p. IO3.-Upon this point, see Hull's "Mount Seir, Sinai, and Western Palestine," pp. 3637; Dawson's "Egypt and Syria," pp. 34-36.

Note 5, p. 105.-The changes of level in the region of the Great Lakes have been carefully investigated by Mr. G. K. Gilbert, of the United States Geological Survey, who concludes thus:- 
"The waters of each lake are gradually rising on the southern and western shores or falling on the northern and eastern shores, or both. . . . Eventually, unless a dam is erected to prevent, Lake Michigan will again overflow to the Illinois River, its discharge occupying the channel carved by the outlet of a Pleistocene glacial lake. The summit in that channel is now eight feet above the mean level of the lake, and the time before it will be overtopped may be computed. Evidently the first water to overflow will be that of some high stage of the lake, and the discharge may at first be intermittent. Such high-water discharge will occur in 500 or 600 years. For the mean lake stage such discharge will begin in about 1,000 years, and after 1,500 years there will be no interruption. In about 2,000 years the Illinois River and the Niagara will carry equal portions of the surplus water of the Great Lakes. In 2,500 years the discharge of the Niagara will be intermittent, failing at low stages of the lake, and in 3,500 years there will be no Niagara. The basin of Lake Erie will then be tributary to Lake Huron, the current being reversed in the Detroit and St. Clair channels" ("Recent Earth Movement in the Great Lakes Region," U. S. Geol. Survey, I 8th An. Rep. ( I 896-97), pt. ii. pp. 639-640).

Note 6, p. I06.-Report of the United States Deep Waterways Commission, i 896, pp. I 55-i68. The facts are more fully stated in my "Scientific Aspects of Christian Evidences," pp. 122-124. 
Note 7, p. Io6.-Proceedings of the Victoria Instisute, vol. xxviii. pp. 267-280.

CHAPTER V.

Note I, p. 143.- In the Quarterly Statement of the Palestine Exploration Fund for July, 1895, will be found a translation, by M. Clermont-Ganneau, of an Arabic account of a similar interruption of the flow of the Jordan twenty-five miles above Damieh in A.D. 1276 (quoted in full by Dr. Bartlett, "Veracity of the Hexateuch," pp. 36I-363).

Note 2, p. I 44.-Proc. of the A. A. A. S., Buffalo, N. Y., I896, pp. I09-1 I I.

Note 3, p. 145.-Dr. Max Blankenkorn, "Entstehung und Geschichte des Todten Meers," Zeit. Deutsch. Palestina-Vereins, vol. xix. p. I.

Note 4, p. 1 50.-A. Benj. Thompson's “ Oil Fields of Russia," pp. 14, 15, from which we cannot resist taking another illustration:-

“. . Fountains which have been burning nearly half a million poods a day, representing a loss of about one hundred pounds per hour to the unfortunate owner, have not been uncommon in the Bibi-Eibat oil field, and for a whole week Baku has been illuminated with sufficient brilliancy to permit reading in the streets all night in the result of the glare from burning fountains at Bibi-Eibat, several miles away. In one fire at Rom- 
any, in 1898 , three fountains were burning simultaneously; and recently in I9OI, a fountain of the Schibaieff Co. at Bibi-Eibat burned a whole week before its force was expended and it could be extinguished. In a recent disastrous fire in the Bibi-Eibat oil field (autumn, I903), sixty-five derricks were burnt, besides numerous reservoirs, buildings, and over I0,000,000 poods [1,000,000 barrels] of oil; and at one time as many as five fountains were burning simultaneously. One fountain burned without cessation for about three weeks."

Note 5, p. I 52.-With this, Sir William Dawson agrees. See his "Syria and Palestine," pp. I 29-131. CHAPTER VI.

Note I, p. I60.-The translation of the cuneiform. sablet is by Professor Paul Haupt, as quoted by Rev. C. J. Ball in "Light from the East" (see Records of the Past (IVashington, D. C.), vol. i. pp. 376-380).

Note 2, p. 176.-We adopt Petrie's estimate of the cubit as $\mathbf{2 2 . 5}$ inches. The ordinary reckoning of $\mathbf{I} 7.75$ inches would reduce the figures by about one-fifth.

Note 3, p. I 76._ “Against Celsus," iv. 4 I.

Note 4, p. I80.--Rev. Joseph B. Davison. See, also, S. E. Bishop's article, "Have We Noah's LogBook," in the Bibliotheca Sacra for July, I906, pp. 5IO-5I7. Dr. Bishop's suggestion was also made independently by Sir IVilliam Dawson. 
Note 5, p. 186.-We have taken the liberty to introduce, with some enlargement, two or three paragraphs from the author's preliminary treatment of the subject in his "Scientific Aspects of Christian Evidences," pages $\mathrm{I}+\mathrm{I}-\mathrm{I}+2$.

Note 6, p. i 89.--The late Professor Tayler Lewis's discussion of this subject is still highly to be commended. See Lange's "Commentary on Genesis," pages 316,318 .

Note 7, p. 190.-Bibliotheca Sacra, April, I890, pp. 285-303. This thoroughgoing article is but an elaboration of a discussion of the subject found in Dr. Green's volume, "The Pentateuch Vindicated from the Aspersions of Bishop Colenso" (New York, John Wiley, i 863 ). See page i 28.

\section{CHAPTER VII.}

Note I, p. 200.--See pages 250 and 252 of the first edition of "Origin of Species" and compare with the third and later editions.

Note 2, p. 20i.-Sec Huxley's "Lay Sermons and Addresses," chap xi. pp. 2+2-2+6.

Note 3, p. 205.-A perusal of the most recent book on geology by Chamberlin and Salisbury deepens the impression concerning the instability of the earth's crust in recent geological time. Speaking of the crustal move- 
ment of the Pliocene (the period which culminated in the Glacial epoch), they say:-

"About the close of the Pliocene there seems tc. have been wide-spread crustal movements in most parts of North America. They resulted in increased height of land, and the time of active erosion which followed is sometimes known as the Ozarkian or Sierran period."

"In the west, there were notably post-Tertiary movements. The plateau region was in process of uplift, periodically, throughout the Tertiary, during which it has been estimated to have undergone an elevation of 20,000 feet (Dutton), and a degradation of I 2,000, leaving it 8,00o feet above sea-level. . . . The later elevations, largely by blocks, were so recent that the fault scarps are almost always ungraded and precipitous, and independent of stratigraphy and drainage.'

"Near the Pacific coast notable changes marked the closing stages of the Pliocene and the transition from it to the Pleistocene. In some parts of southern California (Fort Frazer, Los Angeles County) marine Pliocene beds are said to occur up to altitudes of 6,000 feet."

"On the whole, the close of the Pliocene must be looked upon as a time of great crustal movement, a critical period in the history of North America. New lands were made by emergence from the sea, and old lands were deformed and made higher; new mountains were made, and old ones rejuvenated; streams were turned from their courses in some places, and nearly 
everywhere started on careers of increased activity. The Ozarkian epoch, the transition from the Tertiary to the Pleistocene, was, so far as North America is concerned, an epoch of great erosion. The fact that such notable changes, with increased elevation of land, occurred during the epoch next preceding the glacial period, led to a wide-spread belief that the elevation was the cause of the climate of the latter period" ("Geology," vol. iii. pp. 3II-3I 7).

Note 4, p. 2 I I.-For a complete summary of facts bearing on the rate of subaërial erosion, see Croll's "Climate and Time," from which we quote as follows:-

"Professor Geikie finds that at the present rate of srosion the following is the number of years required by the undermentioned rivers to remove one foot of rock from the general surface of their basins. Professor Geikie thus shows that the rate of denudation, as determined from the amount of sediment carried down the Mississippi, is certainly not too high. Danube, 6,846 years; Mississippi, 6,000 years. Nith, 4,723 years; Ganges, 2,358 years; Rhone, I,528 years; Hoang Ho, I,464 years; Po, 729 years" (pp. 332-333).

Note 5, p. 215.-For a full statement of facts on this subject, see J. D. Whitney's great work on "The Climatic Changes of Later Geological Times," pages I 33-I 34 .

The latest information, amply supporting that of 
Professor Whitney, has been furnished by Mr. Ellsworth Huntington. See "No. 26, Explorations in Turkestan. By Raphael Pumpelly, W. M. Davis, R. W. Pumpelly and Ellsworth Huntington" (Carnegic Institution of Washington).

Note 6, p. 216.-Calculating the area of the Dead Sea basin south of Lake Galilee as 1 to miles long and 75 miles broad, its area is 10,500 square miles. Reckoning the rate of erosion the same as that in the Mississippi Valley (one foot in 5,000 years, which, notwithstanding the dryness of the climate, is probably below the fact, on account of the steep gradient of the streams and the violence of the occasional storms), we obtain an accumulation of thirty feet in 5,000 years over the area of the lake itself, which is forty-seven miles long, with an average of eight miles in width. As the greatest depth of the lake ( 1,278 feet) is only in a small area, it is a liberal allowance to reckon the average depth at one-fourth this amount, or about 300 feet. At the present rate of deposition, this would be filled in 50,000 years.

Note 7, p. 217.--The facts concerning changes of level during the Pleistocene, or Glacial epoch, are thus stated by Chamberlin and Salisbury:-

". . . evidence of Pleistocene changes of level, as distinct from late Pliocene, are not wanting, especially 
near the coasts and about the shores of the Great Lakes. From the evidence at hand, it appears that deformative movements were wide-spread both in the western mountains and in the area covered by the great icesheets. There have also been changes of level, though probably less extensive, in the non-glaciated area of the southern and southeastern part of the continent.

"As already noted, some of the islands of southern California seem to have risen something like I,500 feet since the Pliocene. Other parts of the California coast, and some of the adjacent islands, have been subsiding during the same period. Near San Francisco, the surface is thought to have ranged from $\mathrm{I}, 800$ feet below its present level to $f 00$ feet above. IValcott has estimated that there has been elevation in the Inyo Mountains of California to the extent of 3,000 feet during the Pleistocene."

"In general, the areas covered by the ice of the glacial period have risen since the ice melted. It is a tenable hypothesis that the rise, or some part of it, has resulted from the melting of the ice, and that it followed a depression occasioned by the weight of the ice. The rise of that land has, in general terms, been greatest where the ice was thickest" (Geology, vol. iii. pp. $\$ 80-48 \mathrm{I})$.

\section{CHAPTER VIII.}

Note I, p. 224.-These estimates of land areas and elevations are taken from the fourth edition of Sir Archibald Geikie's "Text-Book of Geology," page 49. 
That the above estimate of the depth of ice over the glaciated area of North America is conservative will appear by consulting Chamberlin and Salisbury's " Geology" (vol. iii. pp. 327-502). They estimate that the continental glacier of North America advanced I,500 or 1,600 miles from the center of displacement (p. 330).

Note 2, p. 226.--The fullest discussion of the question of the rate of increase of temperature on descending below the surface of the earth is to be found in Prestwich's "Controverted Questions in Geology," pages 146-279. His conclusions are, that the average rate of increase is $\mathrm{I}^{\circ} \mathrm{Fahr}$. for every 49.9 feet. The record of the deepest well in the United States is that in West Elizabeth, Pa., twelve miles southeast of Pittsburgh, which penetrated to a depth of 5,575 feet. At 5,380 feet the temperature was $127^{\circ} \mathrm{Fahr}$. an increase of $\mathrm{I}^{\circ}$ for every 69.5 feet (West Virginia Geological Survey, vol. i. (a) p. 104).

Note 3, p. 236.--See Chamberlin and Salisbury's “Geology," vol. iii. pp. 517-519; also James D. Dana's "Manual of Geology" (4th ed., I895), p. 1012. CHAPTER IX.

Note I, p. 239.- See "Ice Age in North America ' and "Man and the Glacial Period."

Note 2, p. 240.-See art. "The Raised Beaches, 
and 'Head' or Rubble Drift, of the South of England: their Relation to the Valley Drifts and to the Glaciai Period; and on a Late Post-glacial Submerge:ce," Quarterly Journal of the Geological Society (London) vol. xlviii. pp. 263-343; art. "The Evidences of a Submergence of Western Europe, and of the Mediterranean Coasts, at the Close of the Glacial or So-calletl Post-glacial Period, and immediately preceding the Neolithic or Recent Period," Philosophical Transactions of the Royal Society of London, vol. clxxxiv. (1893) A. pp. 903-984; "A Possible Cause for the Origin of the Tradition of the Flood," and "On Cextain Phenomena belonging to the Close of the Last Geological Period and of their Bearing upon the Tradition of the Flood" (Macmillan and Company, 1895).

Note 3, p. 240.-See pages 149-162.

Note 4, p. 250.-Art. "Pacific Coast Earthquakes," Independent, April 26, 1906, pp. 956-958. A fuller report by Professor Tarr (and Mr. Lawrence Martin) is found in a paper entitled "Recent Changes in the Yakutat Bay Region, Alaska," Bulletin of the Geological Society of America, vol. xvii. pp. 29-64.

Note 5, p. 253.-See Quarterly Journal of Geology, vol. iv. ( 1848 ) p. 90. 
CHAPTER $\mathrm{X}$.

Note I, p. 283.-Among the author's publications of the results growing out of these investigations, the following are specially to be noted: "Asiatic Russia" (McClure, Phillips \& Company, I9O2, 2 vols., pp. $637)$; art. "Recent Geological Changes in Northern and Central Asia," Quarterly Journal of the Geological Society, vol. lvii. pp. 244-250; "Geology and the Deluge," McClure’s Magazine, June, I90 I, pp. I34I39; "Origin and Distribution of the Loess in Northern China and Central Asia,", Bulletin of the Geological Society of America, vol. xiii. pp. I27-138; "Archæological Notes from Sweden," Records of the Past, November, 1905, pp. 329-333; "The Cedars of Lebanon," Records of the Past, July, I 906, pp. 195-204. See, also, Professor P. Armaschevsky's art. "Human Remains below the Loess of Kief," Records of the Past, September, I902, pp. 275-278.

Note 2, p. 297.--See "Asiatic Russia," vol. ii. pp. $485-5$ I 6 .

Note 3, p. 297.-See Prof. T. C. Chamberlin's report upon the "Driftless Area of the Upper Mississippi Valley," U. S. Geol. Survey, 6th An. Rep., pp. 278-307. A summary of facts is given in the author's "Ice Age in North America," chap. xvi. 
Note 4, p. 301.-A American Journal of Scicnce, vol. clvii., I 879, pp. I33-I 39 .

Note 5, p. 310.-See Sven Hedin's "Central Asia and Tibet," vol. i. pp. 37t-389.

Note 6, p. 313.- See author's art. "The Cedars of Lebanon," Records of the Past, July, 1900, pp. 195$2 \mathrm{O}+$.

Note 7, p. 318.- See Professor P. Armaschevsky in "Memoirs of the Geological Committee of Russia," vol. xv. no. I, pp. 256-316, being a report upon the geology of Poltava, Charkov, and Obojan, Igoz.

The region described lies between the Dnieper and Don rivers, and is partly encroached upon, and nearly surrounded by, the glaciated area. With the retreat of the glacier to the north, there was an abundant overflow of water from the melting surface of the ice, which would bring in sediment to settle in all the depressions, and tend to level up the surface. According to Professor Armaschevsky, the order of events was:-

"First, an epoch of erosion, with a cold, moist climate, during which there disappeared, in order, man and various species of animals, including the mammoth and the musk ox. Secondly, a period of a more moderate, dryer climate, when the loess wals swept off into the valley, forming extensive alluvial terrace deposits 
along the streams. Thiruly, a second period of erosion, with a moister climate, such as has been continued to the present day.'

On page 3 Io he speaks of the variation of the erosive agencies during the accumulation of the loess as not attributable to a single cause, "but to a diminishing moistness of climate, which went hand in hand with the retreat of the glacial ice-cap to the north, and in connection with a well-known elevation of the Black Sea."

Professor Armaschevsky, however, lays great stress upon the action of rivulets in transferring the loess from higher to lower levels, and does not give the prominence to the glacial origin of the loess which the facts would seem to warrant. He instances the occurrence of the loess over the provinces of Poldolia, Bessarabia, Kherson, Ekaterinoslav, and Taurida as evidence that it is not always due to glacial action, since the region lies in some instances a hundred miles outside of the glaciated area. But it is to be noted that this entire area was subject to overflow by glacial streams.

My own examination of the region leads me to supplement Professor Armaschevsky's theory about as follows:- 
During the Glacial epoch the extensive depression, most evident in the Scandinavian peninsula, affected to a greater or less extent the entire region covered by the ice (which extended to within 200 miles of the Black Sea) and to a considerable extent the Black Sea region itself. There was thus a differential depression of the country to the north, producing slack water in the valleys of the Dniester, the Bug, the Dnieper, the Donetz, and the Don, which, hence, were periodically gorged with floods of enormous extent, overflowing their banks far and wide, and leaving their deposits in the still water of the consequent lakelike expansions, much as was the case in the Missouri Valley (see pp. 334-347). It is not necessary to suppose a depression in South Central Russia that was below sea-level, as was the case in Scandinavia and Northern Russia, and probably in regions immediately adjoining the Black Sea. But the changes of level were extensive, and such as to subject both men and animals to conditions so unfavorable that they all alike sooner or later perished.

Note 8, p. 320.- “Through Siberia," page i6r.

Note 9, p. 320.-Quarterly Journal of the Geological Society, vol. lvii. p. 249

Note 10, p. 32 I.-Art. "Recent Geology of Spitzbergen," Journal of Geology, vol. xiii. pp. 61 1-616. 
CHAPTER XI.

Note I, p. 324.-The literature concerning the glacial lakes of North America is very abundant. For a summary, see my "Ice Age in North America," chap. xv., and Chamberlin and Salisbury's "Geology," vol. iii. pp. 394-402. More detailed reports will be found in E. W. Claypole's art. "The Lake Age in Ohio," Transactions of the Geological Society of Edinburgh, I 887 ; Warren Upham's "Glacial Lake Agassiz," U. S. Geol. Survey, Monograph XXV.; F. B. Taylor's "Account of the History of the Great Lakes," in "Studies in Indiana Geography"; Dana's "Manual of Geology" (4th ed.), page 982; Frank Leverett's "Glacial Formations and Drainage Features of the Erie and Ohio Basins," U. S. Geol. Survey, Monograph XI.I.; H. L. Fairchild's "Glacial Waters in the Finger Lakes Region of New York," Bulletin of the Geological Society of America, vol. x. pp. 28-68.

Note 2, p. 34t.-For this important suggestion, I am indebted to Miss Luella A. Oren, of St. Joseph, Mo., whose interest in the subject has been very productive of results. For a fuller discussion of the significance of the boulders of Tuscumbia, see, in the American Geologist, April, 1904, Miss Owen's art. (pp. 223-228), and my art. (pp. 205-222). 
Note 3, p. 347.-This important discovery, made by Mr. Martin Concannon while excavating a tunnel underneath his residence, was first recognized and brought to the notice of the public by Mr. M. C. Long, of Kansas City, Mo., who has presented the remains to the public museum of the city. Their glacial age has been defended by Dr. Warren Upham and Professor N. H. Winchell: The latter, after three extended examinations of the region, would seem to place the matter beyond doubt in his extended and masterly report, published in the American Geologist, May, I903, pp. 263-308. My own conclusions, after several visits, coincide with those of Upham and Winchell. (See art. "The Age of the Lansing Skeleton," Recorls of the Past, April, 1903, pp. 119-124.) An adverse view assigning the deposits to a somewhat later period, but still acknowledging their great antiquity, is advocated by Professors Chamberin, Salisbury, and Calvin, American Journal of Geology, vol. x. p. $7+5$ et seq. A still later discovery, made by Mr. Robert F. Gilder, in the summer of I906, would seem to place beyond question the fact of man's contemporaneousness with the deposit of the Missouri loess. The geological facts involved are discussed in the Records of the Past, February, 1907, by Professor Erwin H. Barbour, of 
the University of Nebraska. The discovery consists of numerous human bones, somewhat waterworn, in undisturbed loess, on Long's Hill, between 150 and 200 feer above the bluff of the Missouri, near Florence, a few miles from Omaha. The fullest summary and discussion of the evidence of glacial man in America is given by Professor N. H. Winchell in the Records of the Past for May and June, 1907.

CHAPTER XII.

Note 1, p. 368.-See "Studies in Science and Religion," pp. 366-367; also "Sermons of the Monday Club for i88I," Introductory Essay.

Note 2, p. 371.--See art. "Creation," Bibliothecn Sacra, April, I885, pp. 20I-224. For earlier articles, see January, I856, pp. 80-I 29; July, I856, pp. 63I-656; April, I857, pp. 388-4I3; July, I857, pp. $461-524$.

Note 3, p. 378.-Art. "The Mosaic Six Days and Geology," Bibliotheca Sacra, January, I857, pp. 6I-98.

Note 4, p. 382.-Expositor, January, I886, page 27.

Note 5, p. 383.-Nineteenth Century, November, I 885 , p. 698.

Note 6, p. 384.- “ Religion of Geology,” page 63. 


\section{INDEX,}

Abbot, Maj.-Gen. H. L., cited, 21 r.

Accommodation, theory of, 24.

Adria, 212.

Agassiz, Louis, cited, 374 .

Ahab, relations of, to Ben-hadad, 58; to Assyria, 58; tc Syria, 59 .

Alaska, 250, 4Ir.

Almanac, importance of, 70 .

Alphabet, Phœnician introduced into Palestine, 158.

America, changes of level in North, 205, 217, 321, 323, 34I 402, 406, 409.

America, North, Deluge in, chapter on, 323-367.

Amraphel. See Khammu-Rabi.

Animals, destruction of, $238,345,352,358$; creation of, 373 ; order of creation, 374 .

Anthropomorphism, 34 .

Ararat, position of, 176 .

Arioch, 157.

Ark, dimensions of, 175 .

Armaschevsky, P., on human remains below the loess, 318, 412 ; on distribution of loess in Russia, $412,413-415$.

Aryan language, center of, 314 .

Asia, 205; excursion across, 227; post-glacial subsidence of, 228; Deluge in, chapter on, 283-322.

Babylon, capture of, 43,49 .

Baku, oil-fields of, 146-150, 403.

Baldwin, Esq., S. Prentiss, quoted, 138 .

Ball, Dr., discovers Canadian boulders at Tuscumbia, 335.

Barbour, Prof. E. H., on the Nebraska man, 4r8.

Barrows, Prof. E. P., quoted, 377.

Bartlett, Pres. S. C., cited, 399, 403. 
Beauterne, Chevalier de, cited, 388.

Beecher, Prof. Willis J., quoted, 390.

Belshazzar, relation of, to Nebuchadnezzar, 48, 395; to Nabonidus, 48, 395 .

Berosus, his account of the Deluge, 172 .

Bertrand, General, cited, 388.

Bibi-Eibat, burning oil-well at, 403 .

Birds, creation of, 380 .

Bishop, Dr. S. E., cited, to+.

Blankenkorn, Max, cited, to3.

Brugsch, H. K., cited, 399.

Buckland, Dean William, on ossiferous fissures, 256.

Duried channels, 218.

Butler, Bishop, quoted, 387 .

Calais, France, $2+1,2+7$.

California, 204, 250, 409 .

Calvin, Prof. Samuel, cited, +17 .

Captivity, return from, 42,43 .

Cartography, exaggerations in, 37 .

Cascades, the, r32-I+r.

Catastrophism in geology, 199 .

Cedars of Lebanon, $3 \mathbf{I} 3$.

Chaloof, 95 .

Chamberlin, Prof. T. C., on instability of the earth's crust, $405-407,408$; on depth of the ice in the Glacial epoch, 4ro; cited, +12, +16, +1 7 .

Champlain period, 323 .

Chazy, N. Y., 331.

Chedor-laomer, 157 .

Chicago, glacial outlet at, 330 .

Chili, 204.

Christ, an historical character, 3 ; the center of Christianity, I 5 ; sublimity of, 20; rules the world by love, $2 \mathbf{1}$; not an imposter, 22 ; or the product of imposture, 23 ; or of legendary growth, 2t; indorses the Old Testament, 27-29. 
Christianity, character of, 3 ; proof of, 4 ; certainty of, 13 ; historical evidences of, $14-26$; in the second century, 19 ; sublimity of, 20 ; not the fruit of imposture, 22; nor of legendary growth, 23 ; nor of delusion, 24.

Cincinnati, glacial floods at, 329.

Claypole, Prof. E. W., on Lake Ohio, 327, 4r6.

Clermont-Ganneau, C. S., cited, 403.

Concannon, Mr. Martin, $+\mathrm{r} 7$.

Connecting links of the argument, $+\mathrm{r}$.

Cotsworth, Mr. Moses B., on the object of the pyramids, 70, 399.

Council Bluffs, $3+3$.

Croll, James, quoted, 407.

Cuneiform tradition of the Deluge, I6I-174.

Cyprus, Island of, ro3.

Cyrus, character of, 43 ; policy of, 392.

Damascus, 123.

Damieh, 403.

Dana, Prof. J. D., cited, $2 \mathbf{I}$, 4 ro; on the Champlain period, 323 ; on Genesis i., 370 ; on the order of creation, $372-375$. 418.

Daniel, historical setting of the book of, 43-52.

Darius the Mede, 50.

Darius, meaning of the word, $5 \mathrm{I}$.

Darwin, Charles, on the rate of erosion, 200; on the destruction of species, 352 .

Davis, Prof. W. M., on glaciers of Central Asia, 300; cited, 407 .

Davison, Rev. Joseph, quoted, r80; cited, 404.

Dawson, Sir William, cited, 98, 11 1, 382 .

Day, meaning of, in Genesis i., $38 \mathbf{I}-383$.

Deluge, traditions of the Noachian, chapter on, 159-197; comparison with other traditions, $160-175$; traditions criticised, 175-179; duration of, 179, 183; extent of, 184-189; object of, 184 ; date of, $189-197$; scientific credibility of the, 
chapter on, 198-219; in Europe, chapter on, 238-282; in Asia, chapter on, 283-322; nature of the evidence, 239; in North America, chapter on, 323-367; destruction of species by, $3+5$.

Denver, elevation of, 205, 206.

Deuteronomy, attributed to Moses, $3 \mathbf{I}$.

Diatessaron of Tatian, 19,389 .

Driver, Prof. S. R., on the meaning of "day" in Genesis i., $381,382$.

Dunes below the "head," $2+5,254$.

Dutton, Major C. E., I32.

Earth, plasticity of, 225; interior temperature of, 226, 372.

Earthquakes, effects of, $126-130,1+1,250$; in Lisbon, 250; in San Francisco, 250; in Alaska, 250.

East Brighton, 24I, 242, $2+4$.

Edwards, Amelia B., cited, 399.

Egypt, Israel in, chapter on, 67-82; famines of, 70; vacillations of the government of, 79 .

Ekron, 398.

Elephants in Europe, 2 r 9.

Emerson, Prof. B. K., quoted, I44.

Emmons, Mr. S. F., quoted, 136 .

Equation, personal, 68.

Erosion, rate of, $2 \mathrm{Ir}$; of limestone, 233.

Esdraelon, valley of, 122, 125 .

Etham, 95.

Europe, changes in level of northwestern, 218; Deluge in, chapter on, 238-282; destruction of animals in, 356 .

Evidence, circumstantial, II6; scientific, II7.

Evolution in geology, 199 .

Exodus, the, chapter cn, 83-ri 7 .

Fairchild, Prof. H. L., cited, +16 .

Falls of Niagara, 229, 234; of St. Anthony, 230, 234.

Famines in Egypt, 70, 73, 74; causes of, 74-79. 
Fish, creation of, 380 .

Fort Wayne, Ind., glacial outlet at, 330 .

Fraas, Dr. Oscar, cited, 98, 99.

Free-will a force, 84 .

Fundy, Bay of, 207.

Gaudry, Prof. A., cited, 260.

Geikie, Sir Archibald, cited, 409.

Geikie, Prof. James, on the loess, 274, 298; cited, 407.

Genealogical tables, 40, 191; condensation of, 192 ; structure of, in Genesis, 195.

Genesis and Science, chapter on, 368-386.

Geological forces not uniform, 200; movements relatively slight, 204; recent great changes, 207, 215.

Gibraltar, Rock of, 262, 263, 267.

Gibbon, Edward, quoted, 398.

Gilbert, Dr. G. K., on Lake Bonneville, 333; on changes of level of lakes, $40 \mathrm{r}$.

Glacial epoch, changes of level during, 205, 217; as a vera causa, chapter on, 220-237; cause of, 220; depth of ice in, $22 \mathrm{I}$; weight of the ice of the, 223; attraction of the ice, 224; depression of land caused by the, 225; limited in Asia, 228, 284; recency of, 229-235; in Mt. Lebanon, 313; boundary in North America, 324; floods in the Ohio, 328; outlet 'at Fort Wayne, 330; floods in the Missouri Valley, 334-345; boundary in Missouri and Kansas, 336 .

Gladstone, Hon. William E., quoted, 378, 382 .

Gobi, Desert of, 214, 300, 309; filled with water, 3 ro.

Gobryas equals Darius the Mede, 51, 395.

Gomorrah. See Sodom and Gomorrah.

Gospels, synoptic, date of, 24 .

Graphite of vegetable origin, 373 .

Green, Prof. William H., on primitive chronology, 40, r9o197, 405 .

Greene, Dr. William B., quoted, 400. 
Guernsey, Island of, 275, 276, 278 .

Guyot, Prof. Arnold, cn Genesis i., 371, 382.

Harnack, Dr. Adolf, cited, 389 .

Laupt, Dr. Paul, his translation of the cuneiform tablet, 404.

"Fiead." See Rubble Drift.

Ledin, Sven, cited, $4{ }^{\mathbf{r}} 3$.

Hengstenberg, E. W., cited, 399.

Herculaneum, destruction of, 202, 203.

Herodotus, 393, 395, his account of the destruction of Sennacherib's army, 5+.

Hezekiah's tribute to Sennacherib, 57.

Hippopotamus in Sicily, 219, 265.

Historical evidence, certainty of, $4, \mathrm{r} 3,385$; of Christianity, I4-26.

Historical language, interpretation of, 33-39, 68 .

Historical perspective, 39 .

History, condensed, 39; fragmentary, to.

Hitchccck, Pres. Edward, quoted, 384 .

Holst, Dr. N. ()., on glacial origin of loess, 298, 302.

Ilopkins, W., on force of moving water, 254.

Howorth, Sir Henry, on the flood, 274.

Hull, Prof. Edward, quoted, 99-101, r02, rо3; cited, for.

Human nature, limitations of, rrg.

Humphreys, Gen. A. A., cited, $2 \mathbf{r r}$.

Huntington, Mr. Ellsworth, on the glaciers of Central Asia, 300 ; cited, 407.

Huxley, Prof. T. H., cited, to5.

Interpretation of rhetorical language, 34,$115 ;$ of condensed history, to, r84, I87; of lyperbolical language, 68, I87. Ismailia, 95 .

Jaffa, roo.

Jebel Attaka, ro9, Iro.

jebel Geneffeh, Iro, ri 2 . 
jebel. Usdum. Its.

Jehoram. coregert, $\rightarrow 9$.

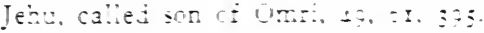

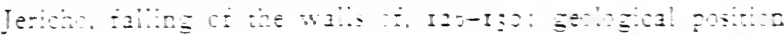
Cㄷㄴ. 12

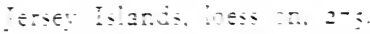

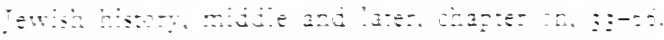

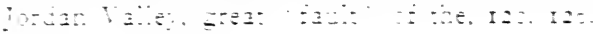

T)

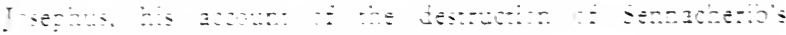

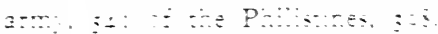

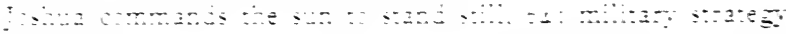

$\therefore \quad: \therefore$

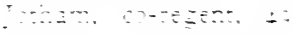

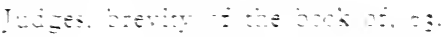

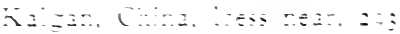

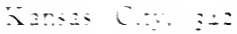

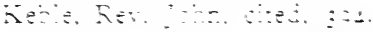

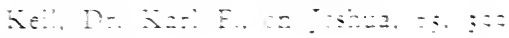

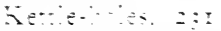

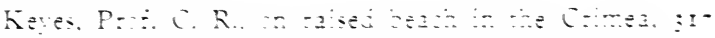

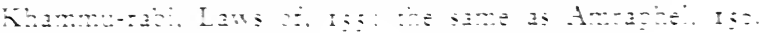

X

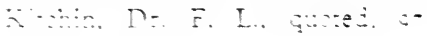

hiser, Ceneza., Iz:

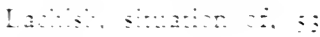

I $\therefore E$.

AzZS:

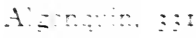

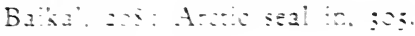

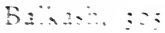

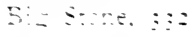

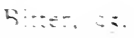

barne, ... 
Lakes.

Erie, effect of wind upon water levels in, ro6.

Galilee, 121, 21 5, 394, 408.

Glacial, 231, 324-345.

Grand Traverse, 332.

Great, 40r.

Great Salt, 2I4, 332.

Huleh, I2r.

Huron, 402.

Lahontan, 334 .

Manytch, an old outlet of the Caspian Sea, 307.

Michigan, 402.

Ohio, 327.

Timsah, 95 .

Victoria, 77 .

Warren, 330.

Land-slides, 138, 140, 141 .

Lang, Dr. John P., cited, 405.

Lansing, Kan., 345 .

Lartet, E., quoted, roo.

Lattakia, raised beach at, ror.

Lawson, Prof. A. C., quoted, 127.

Level, changes in land, 105, 204; about the Great Lakes, 105; water affected by wind, 106; Erie, 106; causes the Deluge, I77; around the Black Sea, 3 I 5 .

Level of land, changes in, 204, 216-219, 240, 321, 323, 340.

Leverett, Mr. Frank, cited, $4 \mathbf{1} 6$.

Lewis, Prof. Tayler, cited, 405.

Light, creation of, 372,376 .

Loess, description of, 272, 297; in Europe, 272; in the Missouri Valley, 272, 297, 342; in Russia, 273, 298; in China, 273, 284; in Central Asia, 273; in the Chinese Sea, 277; in pass of Nankau, 288; at Shiwantse, 294; of glacial origin, 298 ; in the Desert of Gobi, 310 ; at Kief, 318 ; land-shells in, 343 .

Log-book of Noah, 180-189. 
Long, Mr. M. C., cited, 4r7.

Lot's wife, fate of, 151 .

Lydda, raised beach at, roo.

Lyell, Sir Charles, geological theories of, $\mathbf{1 9 9 .}$

Mair, Rev. Alexander, quoted, 388.

Mammoth in Siberia, $3+8$.

Manchuria, no glacial epoch in, 228.

Man, creation of, 375,380 .

Martin, Mr. Lawrence, cited, 4 Ir.

Martinique, 20.4.

Martyr, Justin, testimony of, 19 .

Merrins, Dr. Edward M., on Nebuchadnezzar's malady, 45; on the destruction of Sennacherib's army, 53, 397; of the Philistines, 55 .

Mesha, king of Moab, 64r.

Mice. See Rats and Mice.

Miller, Hugh, cited, 186.

Miracles and natural laws, 84-87; enumerated, 86, I19.

Moabite Stone, the, $6 \mathbf{r}$.

Mokattam Hills, 99.

Mongolia, no glacial epoch in Eastern, 227; loess in Eastern, 291.

Montholon, General, cited, 388.

Montreal, changes in level at, 205.

Moon, set as a sign of seasons, 379 .

Moses, author of the Pentateuch, 26-32; Song of, 9r.

Mountains.

Alps, recent elevation of, 204 .

Altai, glaciers in, 312 .

Andes, 204.

Gilboa, 394 .

Himalayas, 204.

Lebanon, I21, 313 .

Little Hermon, 394.

Pyrenees, 204. 


\section{Mountains}

Rocky, 204.

Tabor, 122, 394.

Tian Shan, 227; glaciers in 300,312 .

Vesuvius, 203.

Nabonidus, career of, 48 ; elasticity of the phrase son of, 49 , 395.

Nankau, loess in pass of, $287,283$.

Napoleon, his testimony concerning Christianity, 20, 388; or. the strategic unimportance of Jerusalem, 123 .

Nature defined, 84 .

Naville, Edouard, on the store cities of Pithom, 82.

Nebuchadnezzar, character of, 45 ; abasement of, 46,393 : his restoration to sanity, +7 .

Newberry, Prof. J. S., quoted, 138.

New Orleans, 2 I I.

New Testament, witness of the, chapter on, 3-32.

Niagara Falls as a glaciometer, 229, 234.

Norway, changes in level of, 218 .

Oberlin, Ohio, glacial phenomena in, 232.

Old Testament, indorsed by the New, 26-31; a unity, $+\mathbf{r}$.

Omaha, Neb., $3+3$.

Omnipotence of God, 86.

Orr, Dr. James, cited, 390.

Orton, Prof. Edward, quoted, r 46.

Ossiferous fissures, 256-272; breccia in, 257; animal remains in, 257; at Santenay, France, 259; theories of, 258-265; at Gibraltar, 262; at Palermo, 265.

Owen, Miss Luella A., on loess of the Missouri Valley, $3+6$, 416.

Palermo, hippopotamus bones at, 265 .

Palestine, physical preparation for Israel in, chapter on, Ir8I58; central position of, 120, 125; geology of, 121, 144, Phœnician alphabet introduced inte, 158 . 
Parsimony, law of, 119.

Peking, ioess on plain of, 286.

Pentateuch indorsed by Christ as a whole, 29: a written document, 30 .

Perspective, in history, 36 ; in cartography, 37 ; in painting, 38 .

Petrie, Dr. Flinders, cited, to+.

Petroleum in the Jordan Valley, $1+4,1+5,150$; in the United States, 146 ; in Southern Russia, 148 ; burning fountains of, I 50, to3.

Philistine epidemic, 55, 398; agency of mice in, 56.

Pi-hahiroth, ro8, rog.

Pinches, Dr. T. G., cited, I 57, 395.

Pithom, 8o, 82.

Plague, bubonic, 53 ; destructivity of, 55 ; symptoms of, 398 .

Plants, creation of, 373,377 .

Poetical license, 34 .

Polytheism counteracted by Genesis i., 368 .

Pompeii, destruction of, 202, 203.

Poole, Edward S., on Egyptian famines, 73.

Post, Rev. George, quoted, ror.

Prestwich, Prof. Joseph, on the Deluge, 240-282; on the rub ble drift, 241-256; on ossiferous fissures, 256-272; on loess, 272-282; on temperature of the earth below the surface, 4 ro.

Proof, scientific, $6,12,83,94,117$; burden of, 16, 32, 42; moral, 18 ; circumstantial, 83, 94.

Pumpelly, Raphael, on Chinese loess, 293; on transporting power of wind, 300 ; cited, 407.

Pumpelly, R. W., cited, to7.

Pusey, Dean, cited, $39+$.

Pyramids, object of, 70; raised beach near, 97.

Raised beaches in Egypt, 97 ; in Syria, roo, ror; on island of Cyprus, 102 ; in Scandinavia, 205, 219; in Southern England, $242,24+245,25+$; on the Jersey Islands, 275 ; around the Black Sea, 317; on the Lena River, 320; in Spitzbergen, 320 ; on Lake Erie, 330 ; at Chazy, N. Y., 33i 
Rameses, 80, 82, 88 .

Ramleh, raised beach at, roo.

Rats and mice, agency of, in bubonic plagues, 54-56.

Richthofen, Baron, on Chinese loess, 273, 292.

Rivers.

Angara, 208, 210, 311.

Chu, 308.

Columbia, submerged trees in, $134,333,338$.

Danube, 338,407 .

Delaware, old channel of, 217 .

Detroit, 402.

Dnieper, 318.

Erie, 402.

Ganges, 407 .

Grand, Mich., 330.

Hoangho, changes in channel of, $28 j, 407$.

Hubbardston, Vt., 337 .

Hudson, old channel of, 217.

Ili, 308 .

Illinois, 402.

Irtysh, 309 .

Jaxartes, 308.

Jordan, 124; parting of the waters of, $130-144,403$.

Khilok, 2 ro.

Lena, 320.

Litany, 125 .

Mohawk, 33 r.

Mississippi, 211, 407, 408.

Missouri, 272, 334 .

Niagara, 402.

Nile, eastern branch of, 103 ; sources of the, 72 ; causes of the overflow of, 72 ; eastern branch of, ro3.

Nith, 407.

Osage, 335 .

Oxus, 308.

Plum Creek, Ohio, a glacial ch:onometer, 232 
Rivers.

Po, 211, 407.

Port Neuf, 333.

Poultney, Vt., 337 .

Red of the North, 332.

Rhine, 274, old course of, 218 .

Rhone, 407.

Selenga, 2 ro, 2 r 2.

Snake, lost, 137, 333 .

St. Clair, 402.

St. Lawrence, old channel of, 218.

Susquehanna, old channel of, 217 .

Tarim, 309.

Tornadus, 177 .

Uda, 2 ro.

Ural, 307.

Volga, 307.

Yangtsekiang, 286.

Zab, 177 .

Romany, burning oil-well at, 403 .

Rousseau concerning Christianity, 22.

Rubble drift, description of, 24I-256; at Calais, 24x ; at Eas: Brighton, 241, 242, 245; at other places in Southern England, 245; distance carried, 246, 249; theories of, 248-256; correct theory of, 251 .

Russell, Prof. Israel C., on Lake Lahontan, 334.

Sahara, Desert of, produces no loess, 302.

Salisbury, Prof. R. D., quoted on the date of the Glacial epoch, 234; on instability of the earth's crust, 405-407, 408; on depth of ice in the Glacial epoch, 410; cited, 416, 417. Salt, around the Dead Sea, 145.

Samaria, 124.

Samaritans, the, 42.

San Francisco, 409; 'earthquake of, 126.

Santenay, mountain of, 259, 262, 267. 
Sayce, Prof. A. H., quoted, 155, 392.

Schaff, Dr. Philip, cited, 389.

Schweinfurth, G. A., cited, 99.

Seals, Arctic, in Lake Baikal and Caspian Sea, 305.

Seas.

Adriatic, $21 \mathrm{r}$.

Aral, 305, saltness of, 214, 306 ; level of, 308 .

Caspian, 213; saltness of, 214, 305, 306; Arctic seal in, 306.

Dead, depth of, 121, to8; geology of, I+4, 215; age of, 2 I 6.

Red, passage of, 87-1r7.

Second Causes, God's relation to, 33-36, 87, 93, I1 8 , 130, 143, 152.

Sediment, amount of, in Chinese rivers, 285.

Sennacherib, destruction of army of, 52-57; referred to by Josephus and Herodotus, 54; agency of mice in, 5+; relations of, to Hezekiah, 57 .

Serbonian Bog, 53, 97.

Shalmaneser II., black obelisk of, 60 .

Shepherd Kings, in Egypt, 7s,

Shishak, expedition of, to Palestine, 62.

Shiwantse, China, houses in the loess at, 290, 294, 295, 296.

Siberia, during the Glacial epoch, 284.

Sicily, hippopotamus in, $219,265,348$.

Sioux City, $3+3$.

Smith, George, quoted, 160.

Sodom and Gomorrah, destruction of, $1+4-152$.

Epartacus, 203 .

Species, stability of, during Tertiary period, 355,356 ; destruction of, $238,3+5,352-358$.

Spitzhergen, changes of level in, 320 .

Stadling, J., on raised beach in Siheria, 320.

Stanley, Dean, cited, 394.

Stevenson, Prof. J. J., on changes of level in Spitzbergen, 320.

St. Helena, 388 . 
St. Joseph, Mo., 272, 343, 346 .

Store cities in Egypt, 80, 82.

Stubbs, Prof. William, cited, 33 .

Sudd, Nile obstructed by, 74-77.

Suez Canal, 95.

Suez, Gulf of, 94; former extension or, 9.

Sun set in the heavens, 379 .

Sungarian depression, 309.

Tarr, Prof. R. S., on earthquake in Alaska, $25 \mathbf{I}, 4 \mathbf{I} \hat{x}$.

Tartars, wanderings of the, 315 .

Tashkent, 299, 305.

Tatian's Diatessaron, 19, 389 .

Taylor, Mr. Frank B., cited, $4 \mathbf{r} 6$.

Temperature of the earth, 226, 372, 4 ro.

Tertiary period, changes of level in, 204.

Texas, oil-wells in, r 46 .

Thompscn, A. B., quoted, 403.

Tidal wases, 250.

Tientsin, formerly on the sea, 286 .

Toledo, Uhio, ro6.

Trebizend, raised beach at, 315,316 .

Tschernyschev, Dr. T. N., on origin of lness, 3 ro.

Tulloch. Major-General, 106.

Tuscumbia, Mo., Canadian boulders at. $335,+16$.

Uniformitarianism in geology, igg.

Upham, Mr. Warren, cited, 416, 417.

Usher, Archbishop, quoted, 189.

Walcott, C. D., cited, 409.

Wallace, Prof. A. R., quoted, 354.

Ward, Mr. John, cited, 399.

West Elizabeth, Pa., 4ro.

Whitney, Prof. J. D., cited, 407.

Willcocks, on sources of the Nile, $74-70$. 
Wilson, Prof. Robert Dick, on Darius the Mede, 50, 397.

Winchell, Prof. Alexander, 382.

Winchell, Prof. N. H., cited, 417, 418.

Wind, effect of, on water levels, ro6; as a transporting agency, 301 ; in the deposition of loess, 302 .

Wright, F. B., journey across Asia, 283.

Wright, Mrs. G. F., journey through Europe, 283.

Writing, early use of, 30 .

Written history, importance of, 4 ; indispensable to progress, 5-8; a stimulus to the intellect, 8-II; capable of a high degree of certainty, II-14.

Xerxes, son of Cambyses, 395.

Xisuthrus, 172. 

. 

